\title{
ॠUSGS
}

science for a changing world

Prepared in cooperation with the Southwest Florida Water Management District

\section{Groundwater Levels, Geochemistry, and Water Budget of the Tsala Apopka Lake System, West-Central Florida, 2004-12}

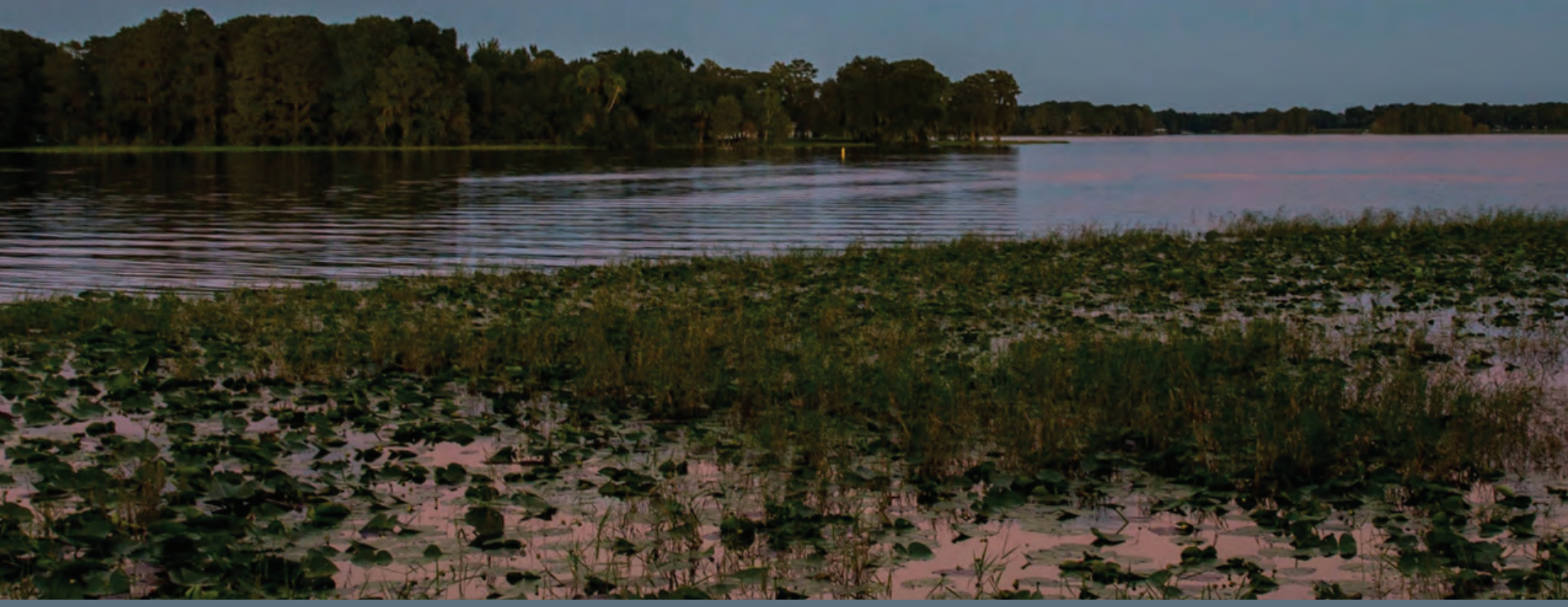

Scientific Investigations Report 2017-5132 
Cover. Henderson Lake at Wallace Brooks Park at Inverness, Florida. Photograph by W. Scott McBride. 


\section{Groundwater Levels, Geochemistry, and Water Budget of the Tsala Apopka Lake System, West-Central Florida, 2004-12}

By W. Scott McBride, Patricia A. Metz, Patrick J. Ryan, Mark Fulkerson, and Harry C. Downing

Prepared in cooperation with the Southwest Florida Water Management District

Scientific Investigations Report 2017-5132 


\title{
U.S. Department of the Interior \\ RYAN K. ZINKE, Secretary
}

\section{U.S. Geological Survey William H. Werkheiser, Acting Director}

\author{
U.S. Geological Survey, Reston, Virginia: 2017
}

For more information on the USGS - the Federal source for science about the Earth, its natural and living resources, natural hazards, and the environment-visit https://www.usgs.gov or call 1-888-ASK-USGS.

For an overview of USGS information products, including maps, imagery, and publications, visit https://store.usgs.gov.

Any use of trade, firm, or product names is for descriptive purposes only and does not imply endorsement by the U.S. Government.

Although this information product, for the most part, is in the public domain, it also may contain copyrighted materials as noted in the text. Permission to reproduce copyrighted items must be secured from the copyright owner.

Suggested citation:

McBride, W.S., Metz, P.A., Ryan, P.J., Fulkerson, Mark, and Downing, H.C., 2017, Groundwater levels, geochemistry, and water budget of the Tsala Apopka Lake system, west-central Florida, 2004-12: U.S. Geological Survey Scientific Investigations Report 2017-5132, 100 p., https://doi.org/10.3133/sir20175132.

ISSN 2328-0328 (online) 


\section{Acknowledgments}

The authors would like to acknowledge numerous individuals at the Southwest Florida Water Management District for their support and assistance in this study, including Ron Basso, Jerry Mallams, Mike Bartlett, Jason LaRoche, Tiffany Horstman, Margit Crowell, Tamera McBride, and Dave Dewitt.

U.S. Geological Survey staff are also acknowledged for their technical assistance with this study, including John Stamm, Tiffany Carson, Arturo Torres, David Sumner, Jason Bellino, Darrell Lambeth and many others in the Lutz and Orlando Data Sections. Nicasio Sepulveda assisted with computation of land-cover grids and evapotranspiration coefficients. 



\section{Contents}

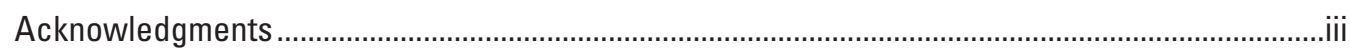

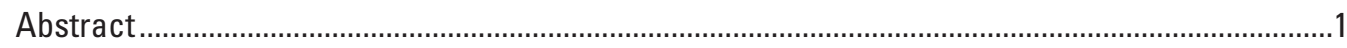

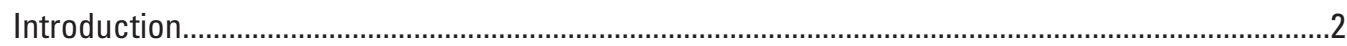

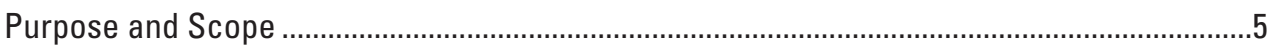

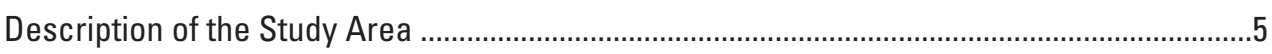

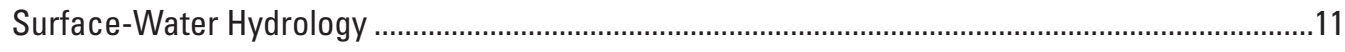

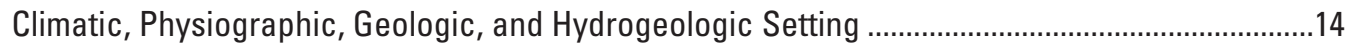

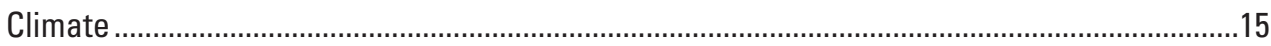

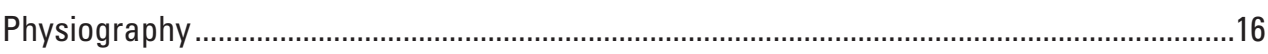

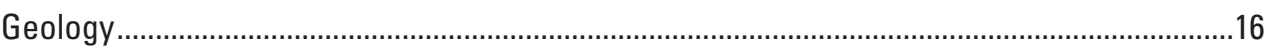

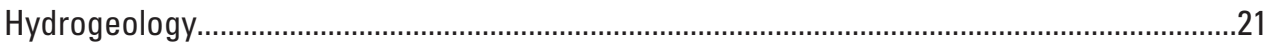

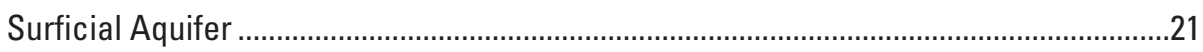

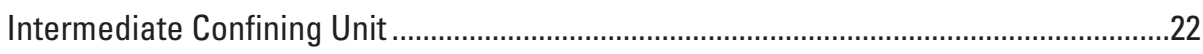

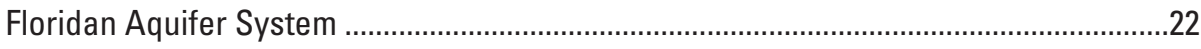

Regional Groundwater Flow ....................................................................................

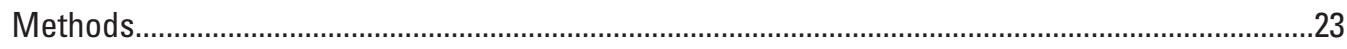

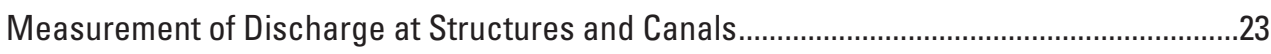

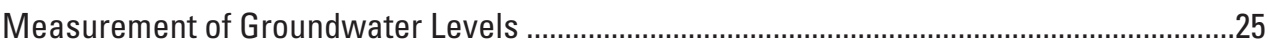

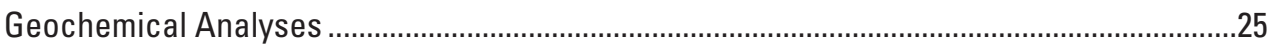

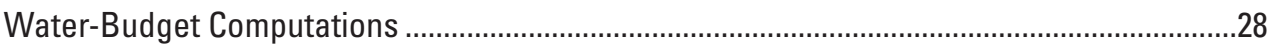

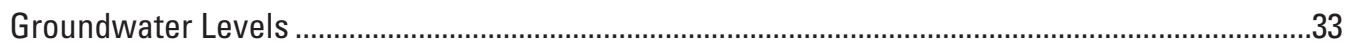

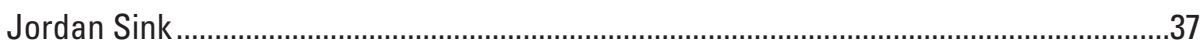

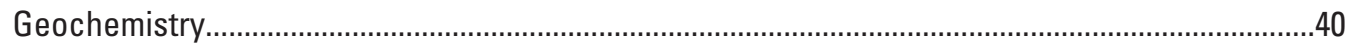

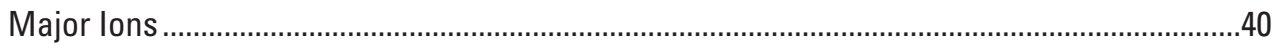

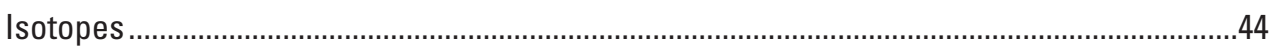

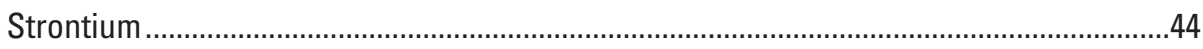

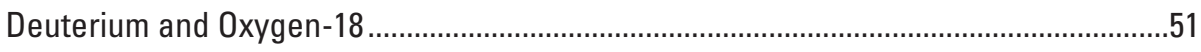

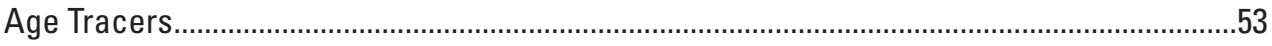

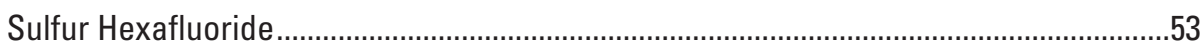

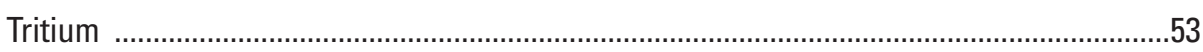

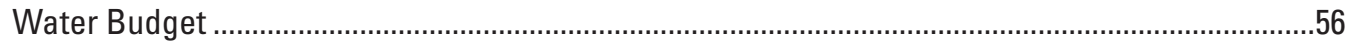

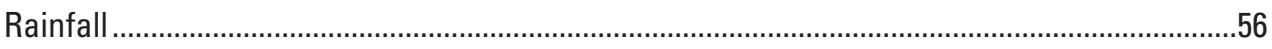

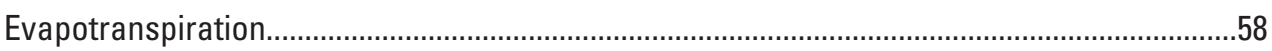

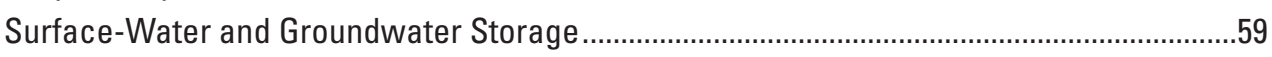

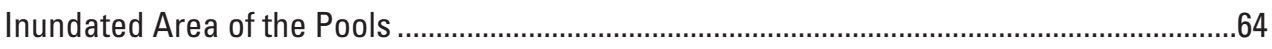

Computed Surface-Water Inflows and Outflows .................................................................

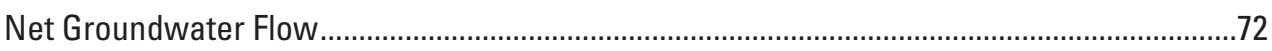

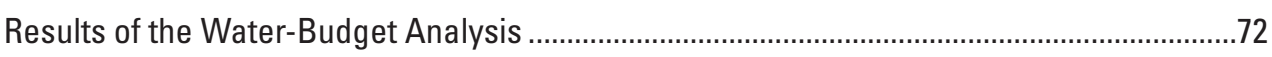

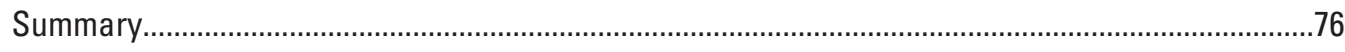

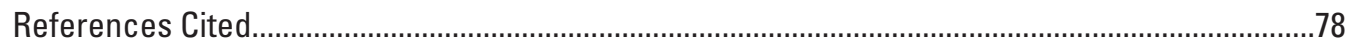

Appendix 1. Detailed Description of Methods of Discharge Computation and

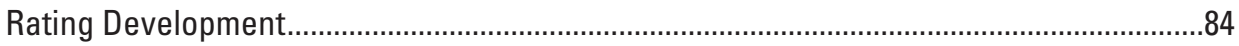




\section{Figures}

1. Map showing the major lakes and three pools that are collectively referred to as Tsala Apopka Lake

2. Map showing pools, canals, and water-control structures located in the Tsala Apopka Lake study area.

3. Diagram of idealized water budget for a pool.

4. Map showing location of sampling and observation stations in the Tsala Apopka Lake study area.

5. Photographs showing water-control structures located at Tsala Apopka Lake .............12

6. Graph showing daily water stages of the Withlacoochee River near Pineola and the Withlacoochee River near Floral City streamgages, 2004-12.

7. Pie diagrams showing availability of Withlacoochee River inflow to the Floral City Pool through the Orange State and Leslie Heifner canals.

8. Graph showing total annual rainfall at the National Oceanic and Atmospheric Administration Inverness 3 SE weather station from 1930 to 2014.

9. Graph showing annual rainfall departure at Tsala Apopka Lake from 1930 to 2014 at the National Oceanic and Atmospheric Administration Inverness 3 SE weather station

10. Map showing physiographic regions of central Florida

11. Correlation chart showing relation of stratigraphic and hydrogeologic units in the Tsala Apopka Lake study area....

12. Map showing geology of the Tsala Apopka Lake area

13. Geologic cross sections showing the geology of the Tsala Apopka Lake area. 20

14. Map showing regional potentiometric surface of the Upper Floridan aquifer, September 2007.

15. Map showing canals and water-control structures used in the step-backwater calculations for estimating flows in the Tsala Apopka Lake area, 2004-12......

16. Graph showing stage-volume relation curves for lakes and connecting wetlands in the Floral City Pool, Inverness Pool, and Hernando Pool

17. Map showing two-kilometer Next-Generation Radar grid cells used in the calculation of rainfall and evapotranspiration in the Floral City Pool, Inverness Pool, Hernando Pool, and the composite three-pool area

18. Maps showing potentiometric surface of the Upper Floridan aquifer in the Tsala Apopka Lake study area during the May-June 2012 dry period and September-0ctober 2012 wet period.

19. Graphs showing hydraulic head at paired well sites TA2 SA and UFA; Flying Eagle SA and UFA; TA6 SA and UFA; TA4 SA and UFA; and ROMP 110 SA and UFA compared to total monthly rainfall at the Inverness 3 SE weather station, October 2011-September 2014.

20. Graphs showing hydraulic head at paired wells and surface-water stations TA5 SA and UFA and Floral City Lake; TA3 SA and UFA and Henderson Lake; and TA1 SA and UFA and Hernando Lake compared to total monthly rainfall at the Inverness 3 SE weather station, October 2011-September 2014.

21. Graphs showing hydraulic head at paired well sites ROMP 109 SA and UFA and ROMP 113 SA and UFA compared to total monthly rainfall at the Inverness 3 SE weather station, October 2011-September 2014 
22. Photographs showing views of Jordan Sink from north rim looking down on pond formed in swallet at base of sinkhole; channelized flow entering the sinkhole in May 2012; and close up of pond and swallet, and weathered limestone boulders

23. Graph showing hydraulic head at Jordan Sink Pond and Jordan Sink Upper Floridan aquifer well compared to nearby Upper Floridan aquifer wells, the Withlacoochee River, and rainfall at the Inverness 3 SE weather station, October 2011-September 2014

24. Trilinear diagrams depicting water types by water source for major-ion samples collected in the Tsala Apopka Lake study area during December 2011 and December 2012

25. Stiff diagrams depicting water types by sample for major-ion samples collected in the Tsala Apopka Lake study area during December 2011 and December 2012

26. Graphs showing relation between strontium isotope ratios and the reciprocal of the strontium concentration in water samples from the Tsala Apopka Lake study area for December 2011 and December 2012

27. Graphs showing strontium-isotope ratios compared to select ions measured in water samples collected from the Tsala Apopka Lake study area in 2011 and 2012.

28. Graphs showing relation between deuterium and oxygen isotopes in the Tsala Apopka Lake study area in December 2011 and December 2012

29. Bar graph showing comparison of annual Next-Generation Radar rainfall for the Floral City Pool, Inverness Pool, and Hernando Pool, 2004-12

30. Graphs showing monthly total of Next-Generation Radar rainfall in the Floral City Pool, Inverness Pool, and Hernando Pool in 2008 and 2011

31. Graph showing Next-Generation Radar monthly rainfall in the composite three-pool area, 2004-12

32. Map showing generalized land cover in the Floral City Pool, Inverness Pool, and Hernando Pool by Next-Generation Radar grid cell

33. Bar graph showing annual actual evapotranspiration rates for the Floral City Pool, Inverness Pool and Hernando Pool, 2004-12

34. Graphs showing time series of daily mean pool stage; hydraulic head; and monthly rainfall in the Tsala Apopka Lake area, 2004-12.

35. Bar graphs showing statistical distribution of water stage data in the Floral City Pool; Inverness Pool; and Hernando Pool, 2004-12.

36. Map showing areas of potential inundation in the Floral City Pool, Inverness Pool, and Hernando Pool at stages of 30-75 feet above the North American Vertical Datum of 1988

37. Maps showing minimum and maximum inundated areas in the Floral City Pool, 2004-12

38. Map showing minimum and maximum inundated areas in the Inverness Pool, 2004-12

39. Maps showing minimum and maximum inundated areas in the Hernando Pool, 2004-12.

40. Graphs showing daily mean of percent inundated area of the Floral City Pool; Inverness Pool; and Hernando Pool, 2004-12.

41. Graphs showing computed surface-water inflows and outflows for the Floral City Pool; Inverness Pool; and Hernando Pool, 2004-12 
42. Graphs showing annual variability of net groundwater flow for the Floral City

Pool; Inverness Pool; Hernando Pool; and composite three-pool area, 2004-12 ...........72

43. Water-budget diagrams for the control volumes of Floral City Pool, Inverness Pool, and Hernando Pool showing the annual mean water budget for 2004-12; a dry year (2006); and a wet year (2012).

44. Graphs showing comparisons of monthly Next-Generation Radar rainfall and computed net groundwater flow in the Floral City Pool; Inverness Pool; and Hernando Pool, 2004-12.

\section{Tables}

1. Sampling and observation stations in the Tsala Apopka area.

2. Range of seasonal air temperature at the National Oceanic and Atmospheric Administration Inverness 3 SE weather station (084289) from 1981 to 2010.

3. Strontium, hydrogen, and oxygen isotope data collected from select groundwater and surface-water sites in the Tsala Apopka Lake study area, December 2011 and December 2012

4. Construction information of wells for which groundwater samples were collected in the Tsala Apopka study area in December 2011 and December 2012.

5. Mean concentrations, mean calculated atmospheric mixing ratios, mean piston flow model years of sulfur hexafluoride data and mean dissolved gas, calculated recharge temperature, and tritium data in groundwater in the Tsala Apopka Lake study area, December 2011 and December 2012.

6. Yearly water-budget terms, computed net groundwater flow, and estimated uncertainty or error associated with the computed net groundwater flow for the Floral City Pool, 2004-12

7. Yearly water-budget terms, computed net groundwater flow, and estimated uncertainty or error associated with the computed net groundwater flow for the Inverness Pool, 2004-12

8. Yearly water-budget terms, computed net groundwater flow, and estimated uncertainty or error associated with the computed net groundwater flow for the Hernando Pool, 2004-12

9. Yearly water-budget terms, computed net groundwater flow, and estimated uncertainty or error associated with the computed net groundwater flow for the composite three-pool area, 2004-12.

10. Monthly mean actual to reference evapotranspiration ratios for various land covers used in the Tsala Apopka Lake water-budget analysis.

11. Land-cover types, percentage of land by type, and acreage of land by type in each Next-Generation Radar grid cell in the Floral City Pool, Inverness Pool, and Hernando Pool, 2011

12. Calculated surface-water flows for Tsala Apopka Lake structures, 2004-12 


\section{Conversion Factors}

U.S. customary units to International System of Units

\begin{tabular}{|c|c|c|}
\hline Multiply & By & To obtain \\
\hline \multicolumn{3}{|c|}{ Length } \\
\hline inch (in.) & 2.54 & centimeter $(\mathrm{cm})$ \\
\hline foot $(\mathrm{ft})$ & 0.3048 & meter (m) \\
\hline mile (mi) & 1.609 & kilometer (km) \\
\hline \multicolumn{3}{|c|}{ Area } \\
\hline acre & 0.004047 & square kilometer $\left(\mathrm{km}^{2}\right)$ \\
\hline square foot $\left(\mathrm{ft}^{2}\right)$ & 0.092903 & square meter $\left(\mathrm{m}^{2}\right)$ \\
\hline micrometer $(\mu \mathrm{m})$ & 0.0000394 & inch (in.) \\
\hline square mile $\left(\mathrm{mi}^{2}\right)$ & 2.590 & square kilometer $\left(\mathrm{km}^{2}\right)$ \\
\hline \multicolumn{3}{|c|}{ Volume } \\
\hline cubic foot $\left(\mathrm{ft}^{3}\right)$ & 0.02832 & cubic meter $\left(\mathrm{m}^{3}\right)$ \\
\hline microliter $(\mu \mathrm{l})$ & 0.0000338 & ounce, fluid (fl. oz.) \\
\hline \multicolumn{3}{|c|}{ Flow rate } \\
\hline cubic foot per second $\left(\mathrm{ft}^{3} / \mathrm{s}\right)$ & 0.02832 & cubic meter per second $\left(\mathrm{m}^{3} / \mathrm{s}\right)$ \\
\hline inch per month (in/mo) & 304.8 & millimeter per year (mm/yr) \\
\hline inch per year (in/yr) & 25.4 & millimeter per year $(\mathrm{mm} / \mathrm{yr})$ \\
\hline \multicolumn{3}{|c|}{ Hydraulic conductivity } \\
\hline foot per day $(\mathrm{ft} / \mathrm{d})$ & 0.3048 & meter per day $(\mathrm{m} / \mathrm{d})$ \\
\hline \multicolumn{3}{|c|}{ Transmissivity* } \\
\hline foot squared per day $\left(\mathrm{ft}^{2} / \mathrm{d}\right)$ & 0.09290 & meter squared per day $\left(\mathrm{m}^{2} / \mathrm{d}\right)$ \\
\hline
\end{tabular}

Temperature in degrees Celsius $\left({ }^{\circ} \mathrm{C}\right)$ may be converted to degrees Fahrenheit $\left({ }^{\circ} \mathrm{F}\right)$ as ${ }^{\circ} \mathrm{F}=\left(1.8 \times{ }^{\circ} \mathrm{C}\right)+32$.

Temperature in degrees Fahrenheit $\left({ }^{\circ} \mathrm{F}\right)$ may be converted to degrees Celsius $\left({ }^{\circ} \mathrm{C}\right)$ as ${ }^{\circ} \mathrm{C}=\left({ }^{\circ} \mathrm{F}-32\right) / 1.8$.

*Transmissivity: The standard unit for transmissivity is cubic foot per day per square foot times foot of aquifer thickness $\left[\left(\mathrm{ft}^{3} / \mathrm{d}\right) / \mathrm{ft}^{2}\right] \mathrm{ft}$. In this report, the mathematically reduced form, foot squared per day $\left(\mathrm{ft}^{2} / \mathrm{d}\right)$, is used for convenience.

\section{Datum}

Vertical coordinate information is referenced to the North American Vertical Datum of 1988 (NAVD 88).

Horizontal coordinate information is referenced to the North American Datum of 1983 (NAD 83).

Elevation, as used in this report, refers to the distance above the vertical datum. 


\section{Supplemental Information}

Specific conductance is given in microsiemens per centimeter at 25 degrees Celsius $(\mu \mathrm{S} / \mathrm{cm}$ at $\left.25^{\circ} \mathrm{C}\right)$.

Concentrations of chemical constituents in water are given in either milligrams per liter (mg/L) or micrograms per liter $(\mu \mathrm{g} / \mathrm{L})$.

\section{Abbreviations}

\begin{tabular}{|c|c|}
\hline${ }^{1} \mathrm{H}$ & hydrogen-1 \\
\hline${ }^{2} \mathrm{H}$ & hydrogen-2 (deuterium) \\
\hline $\mathrm{D}$ & hydrogen-2 (deuterium) \\
\hline${ }^{3} \mathrm{H}$ & hydrogen-3 (tritium) \\
\hline $0^{16}$ & oxygen-16 \\
\hline $0^{18}$ & oxygen-18 \\
\hline${ }^{86} \mathrm{Sr}$ & strontium-86 \\
\hline${ }^{87} \mathrm{Sr}$ & strontium-87 \\
\hline AET & actual evapotranspiration \\
\hline bls & below land surface \\
\hline $\mathrm{e}_{\text {Gnet }}$ & error in net groundwater flow \\
\hline GMWL & global meteoric water line \\
\hline $\mathrm{G}_{\text {net }}$ & net groundwater flow \\
\hline GW & groundwater \\
\hline HMLL & high minimum lake level \\
\hline lidar & light detection and ranging \\
\hline LMWL & local meteoric water line \\
\hline MLL & minimum lake level \\
\hline $\mathrm{N}$ & normal \\
\hline NCDC & National Climatic Data Center \\
\hline NEXRAD & Next-Generation Radar \\
\hline NIST & National Institute of Standards and Technology \\
\hline NOAA & National Oceanic and Atmospheric Administration \\
\hline per mil & parts per thousand \\
\hline 0 & discharge \\
\hline QW & quality of water \\
\hline RET & reference evapotranspiration \\
\hline
\end{tabular}




$\begin{array}{ll}\text { ROMP } & \text { Regional Observation and Monitoring-Well Program } \\ \text { SA } & \text { surficial aquifer } \\ \text { SF }_{6} & \text { sulfur hexafluoride } \\ \text { SW } & \text { surface water } \\ \text { SWFWMD } & \text { Southwest Florida Water Management District } \\ \text { UFA } & \text { Upper Floridan aquifer } \\ \text { USGS } & \text { U.S. Geological Survey } \\ \text { WL } & \text { water level }\end{array}$





\title{
Groundwater Levels, Geochemistry, and Water Budget of the Tsala Apopka Lake System, West-Central Florida, 2004-12
}

\author{
By W. Scott McBride,' Patricia A. Metz, ${ }^{1}$ Patrick J. Ryan, ${ }^{1}$ Mark Fulkerson, ${ }^{2}$ and Harry C. Downing ${ }^{2}$
}

\section{Abstract}

Tsala Apopka Lake is a complex system of lakes and wetlands, with intervening uplands, located in Citrus County in west-central Florida. It is located within the 2,100 square mile watershed of the Withlacoochee River, which drains north and northwest towards the Gulf of Mexico. The lake system is managed by the Southwest Florida Water Management District as three distinct "pools," which from upstream to downstream are referred to as the Floral City Pool, Inverness Pool, and Hernando Pool. Each pool contains a mixture of deep-water lakes that remain wet year round, ephemeral (seasonal) ponds and wetlands, and dry uplands. Many of the major deep-water lakes are interconnected by canals. Flow from the Withlacoochee River, when conditions allow, can be diverted into the lake system. Flow thorough the canals can be used to control the distribution of water between the three pools. Flow in the canals is controlled using structures, such as gates and weirs.

Hydrogeologic units in the study area include a surficial aquifer consisting of Quaternary-age sediments, a discontinuous intermediate confining unit consisting of Miocene- and Pliocene-age sediments, and the underlying Upper Floridan aquifer, which consists of Eocene- and Oligocene-age carbonates. The fine-grained quartz sands that constitute the surficial aquifer are generally thin, typically less than 25 feet thick, within the vicinity of Tsala Apopka Lake. A thin, discontinuous, sandy clay layer forms the intermediate confining unit. The Upper Floridan aquifer is generally unconfined in the vicinity of Tsala Apopka Lake because the intermediate confining unit is discontinuous and breached by numerous karst features. In the study area, the Upper Floridan aquifer includes the upper Avon Park Formation and Ocala Limestone. The Ocala Limestone is the primary source of drinking water and spring flow in the area.

The objectives of this study are to document the interaction of Tsala Apopka Lake, the surficial aquifer, and the Upper Floridan aquifer; and to estimate an annual water budget for each pool and for the entire lake system for 2004-12. The

\footnotetext{
${ }^{1}$ U.S. Geological Survey.
}

${ }^{2}$ Southwest Florida Water Management District. hydrologic interactions were evaluated using hydraulic head and geochemical data. Geochemical data, including major ion, isotope, and age-tracer data, were used to evaluate sources of water and to distinguish flow paths. Hydrologic connection of the surficial environment (lakes, ponds, wetlands, and the surficial aquifer) was quantified on the basis of a conceptualized annual water-budget model. The model included the change in surface water and groundwater storage, precipitation, evapotranspiration, surface-water inflow and outflow, and net groundwater exchange with the underlying Upper Floridan aquifer. The control volume for each pool extended to the base of the surficial aquifer and covered an area defined to exceed the maximum inundated area for each pool during 2004-12 by 0.5 foot. Net groundwater flow was computed as a lumped value and was either positive or negative, with a negative value indicating downward or lateral leakage from the control volume and a positive value indicating upward leakage to the control volume.

The annual water budget for Tsala Apopka Lake was calculated using a combination of field observations and remotely sensed data for each of three pools and for the composite three pool area. A digital elevation model at a 5-foot grid spacing and bathymetric survey data were used to define the landsurface elevation and volume of each pool and to calculate the changes in inundated area with change in lake stage. Continuous lake-stage and groundwater-level data were used to define the change in storage for each pool. The rainfall data used in the water-budget calculations were based on daily radar reflectance data and measured rainfall from weather stations. Evapotranspiration was computed as a function of reference evapotranspiration, adjusted to actual evapotranspiration using a monthly land-cover coefficient (based on evapotranspiration measurements at stations located in representative landscapes). Surface-water inflows and outflows were determined using stage data collected at a series of streamgages installed primarily at the water-control structures. Discharge was measured under varying flow regimes and ratings were developed for the water-control structures. The discharge data collected during the study period were used to calibrate a surface-water flow model for 2004-12. Flows predicted by the model were used in the water-budget analysis. Net groundwater flow was determined as the residual term in the water-budget equation. 
The results of the water-budget analysis indicate that rainfall was the largest input of water to Tsala Apopka Lake, whereas evapotranspiration was the largest output. For the 2004-12 analysis period, surface-water inflow accounted for 11 percent of the inputs, net groundwater inflow accounted for 1 percent of inputs (annual periods with positive net groundwater flow were included as inputs, while annual periods with negative net groundwater flow were counted as outputs), and rainfall accounted for the remaining 88 percent. For the same period, the outputs consisted of 2 percent surface-water outflow, 12 percent net groundwater outflow, and 86 percent evapotranspiration. Net groundwater inflows and surfacewater/groundwater storage were negligible during the waterbudget period but could be important components of the budget in individual years.

The net groundwater flow was negative (downward) for 8 out of the 9 years modeled (2004-12), indicating that the Tsala Apopka Lake study area was primarily a recharge area for the underlying Upper Floridan aquifer during this time period. Groundwater-level elevation in paired wells (adjacent wells completed in the surficial aquifer and Upper Floridan aquifer) typically was higher in the surficial aquifer than the Upper Floridan aquifer. However, hydraulic head data indicate that the surficial aquifer often has discharge potential to the surface-water system, especially in the low lying areas near the major lakes. Surficial-aquifer water levels were often higher than lake stages, especially during wet periods, which is likely an indication of aquifer-to-lake seepage in these areas. East of the major lakes, hydraulic head data were nearly equal in the surficial aquifer and Upper Floridan aquifer, which is an indication that the Upper Floridan aquifer is unconfined. Based on deuterium and oxygen stable isotope data collected in December 2011 and December 2012, there was no evidence of recharge to the Upper Floridan aquifer from the wetlands east of the major lakes; aquifer isotopic ratios did not indicate an enriched source, which is typical of lake and wetland sources. West of the major lakes, there was evidence of enriched isotopic ratios in water samples from the Upper Floridan aquifer. Differences in hydraulic head at paired wells in the surficial aquifer and Upper Floridan aquifer indicated that the surficial aquifer has the potential to recharge the Upper Floridan aquifer in the western part of the pools and west of the major lakes.

\section{Introduction}

Legislation enacted in 1993 mandated that the State of Florida develop and implement measures to protect ecosystems (Southwest Florida Water Management District, 2007). Watershed management is one of the main components of the legislation. A key objective of watershed management is the protection of the quality and quantity of the surface-water and groundwater resources. The State of Florida and the Southwest Florida Water Management District (SWFWMD) acquired conservation properties in and around Marion, Sumter, and Citrus Counties (fig. 1) to protect, restore, and maintain the land and water resources of the area (SWFWMD, 2011). These properties include Flying Eagle Preserve, Potts Preserve, Two Mile Prairie, and others (fig. 1). The purchase and preservation of these properties aids in aquifer recharge, flood control, wetlands protection, water storage, and in the protection of water quality. This area includes a complex system of interconnected lakes and wetlands, with intervening uplands, that are collectively referred to as Tsala Apopka Lake.

Tsala Apopka Lake is located within the 2,100 square mile $\left(\mathrm{mi}^{2}\right)$ watershed of the Withlacoochee River (SWFWMD, 2014a) and is managed by the SWFWMD (SWFWMD, 2014a). The Withlacoochee River, which flows northwest for about 160 miles (mi) from the Green Swamp to the Gulf of Mexico (fig. 1), interacts with Tsala Apopka Lake through a series of natural wetlands and constructed canals. Tsala Apopka Lake is divided into three hydrologically distinct regions known as "pools." The topographic and management boundaries for the three pools are shown in figure 2. The larger pool area and more generalized boundary is the traditional management boundary separating the three pools from one another. Within the management boundary is the smaller and more carefully defined boundary calculated based on topographic divides and maximum flooded area from 2004 to 2012. The topographic-based boundary was used herein when calculating water budgets for each pool. In downstream order, from southeast to northwest, the three pools are Floral City Pool, Inverness Pool, and Hernando Pool (figs. 1 and 2). An arrangement of man-made canals allows for navigation within and between pools. Gravity-fed water-control structures are managed by the SWFWMD to assist in water conservation and flood protection throughout Tsala Apopka Lake (SWFWMD, 2007; 2010) (fig. 2). Hereinafter, reference to a pool will be with respect to its topographic-based boundary, unless otherwise specified as the management boundary; water-control structures will be referred to as "structures."

Tsala Apopka Lake is an area of karst terrain, which is defined as a geologic setting in which limestone is at or near land surface, and has landforms that result from dissolution of limestone (Monroe, 1970). Hydrogeologic units in the study area include a surficial aquifer consisting of Quaternary-age sediments, a discontinuous intermediate confining unit consisting of Miocene-age and Pliocene-age sediments, and the underlying Upper Floridan aquifer (Miller, 1986; Williams and Kuniansky, 2015). The Upper Floridan aquifer and underlying Lower Floridan aquifer together constitute the Floridan aquifer system. Unique problems can arise in protecting and managing surface-water and groundwater quality in karst terrain because of the rapid recharge and transport of water through conduits and caves in the subsurface (Fetter, 1994; Mahler and others, 2000). Therefore, water-resource managers need detailed hydrologic and hydrogeologic data to determine the complex interactions between groundwater and surface water in Florida's karst environment. 


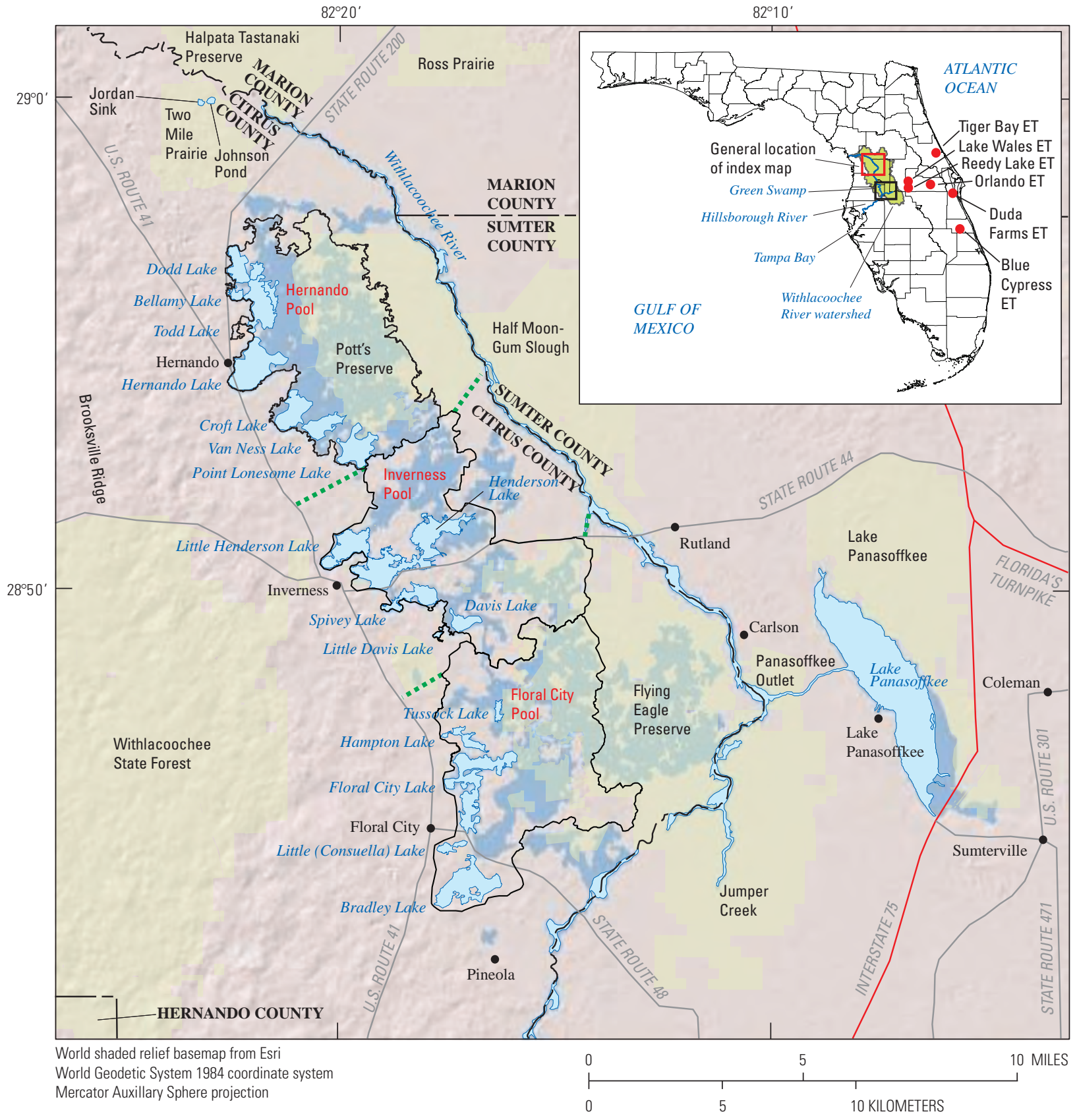

EXPLANATION

Conservation property owned by

the State or Southwest Florida

Water Management District

Area of periodic inundation

Pool topographic boundary

- - Pool management boundary

- Evapotranspiration (ET) station

Figure 1. The major lakes and three pools that are collectively referred to as Tsala Apopka Lake. 


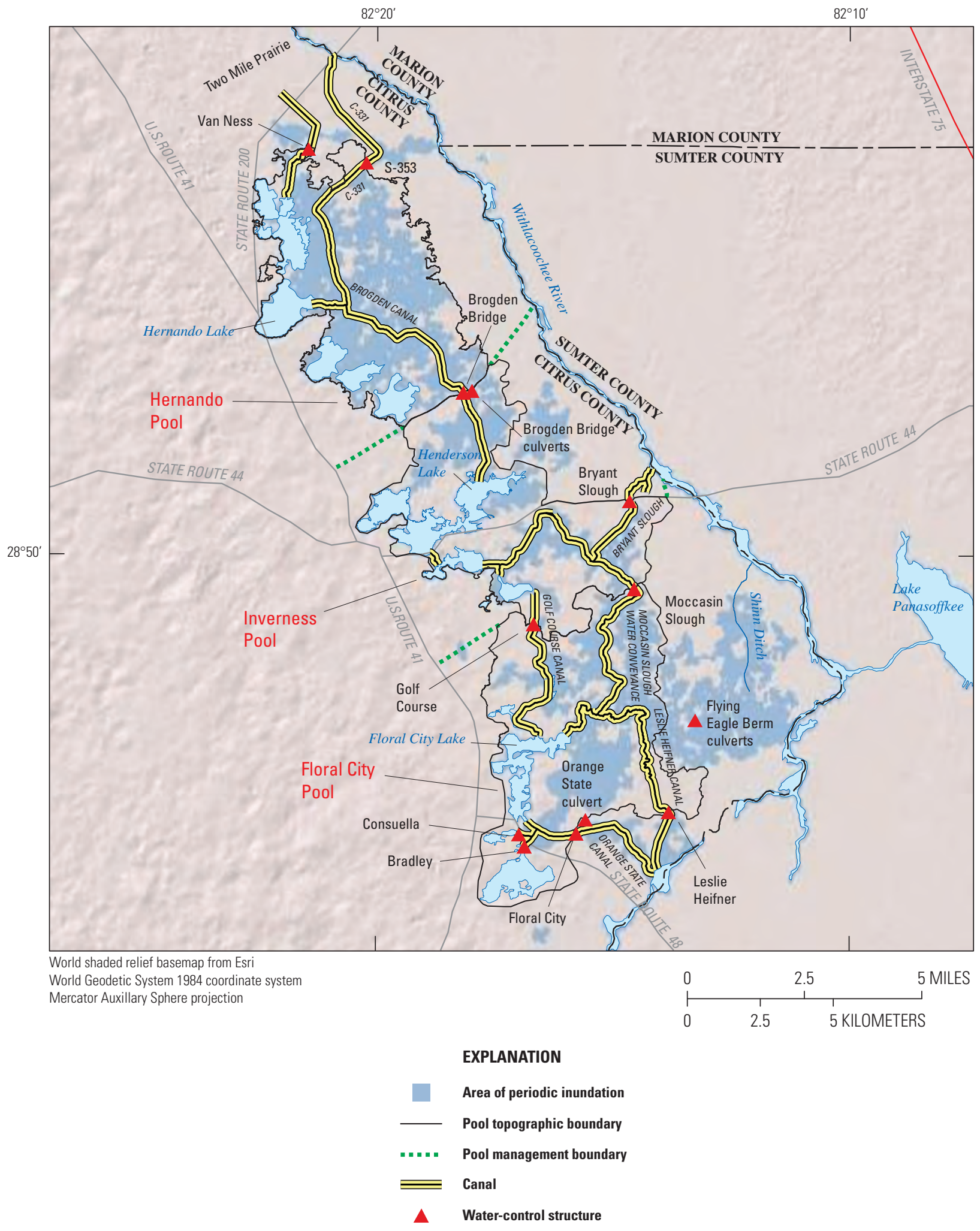

Figure 2. Pools, canals, and water-control structures located in the Tsala Apopka Lake study area. 
Central Florida is projected to develop rapidly in coming years (SWFWMD, 2015a). Water managers and local residents have expressed concern that population increases in the Withlacoochee River Basin, along with the ensuing development, might affect surface-water and groundwater resources. Previous studies, such as for Lake Panasoffkee and the Withlacoochee River, have shown that a strong hydraulic connection exists between surface water and groundwater in the area (Trommer and others, 2009; McBride and others, 2011). Tsala Apopka Lake is a difficult resource to manage due to its complexity, which is evidenced by the network of interconnecting canals (fig. 2). Reliable data on the nature of the hydraulic connection between the lakes and wetlands and the Upper Floridan aquifer are limited; analytical water budgets have never been developed for the system. Understanding how water moves through the system and interacts with the underlying aquifers would give water managers better insight into how to manage the system. To address this need, the U.S. Geological Survey (USGS), in cooperation with the SWFWMD, initiated a study in 2010 that included field data collection and a data analysis to quantify and document the hydrologic and hydrogeologic characteristics of Tsala Apopka and its three pools.

\section{Purpose and Scope}

The purpose of this report is to document the interaction of surface water and groundwater, and the annual water budget for Tsala Apopka Lake for 2004-12, including separate budgets for the Floral City, Inverness, and Hernando Pools (figs. 1 and 2). Interaction and sources of water- to the groundwater and surface-water systems - were determined through geochemical analyses of water samples taken in 2011-12 at surface-water and groundwater sites within the study area. The annual water budget for 2004-12 includes surface-water evaporation (from lake surfaces), evapotranspiration, rainfall, surface-water flow, groundwater flow into and out of the surficial aquifer, and changes in surface-water and groundwater storage (fig. 3). The control volumes of the water budget are the defined topographic areas of each pool (figs. 1 and 2) and extend to the base of the surficial aquifer. Field measurements of stream and canal flows were made under varying conditions to establish the hydrology of the surface-water system and to quantify the volume of flow and establish rating curves of streamflow (fig. 4 and table 1). Continuous groundwater-level data were collected at 10 sets of paired wells (owned by the SWFWMD) that are installed in the surficial and Upper Floridan aquifers to define groundwater flow patterns in the Tsala Apopka Lake region (fig. 4 and table 1).

\section{Description of the Study Area}

Tsala Apopka Lake is not a single lake but is rather a chain of major lakes interconnected by canals, sloughs, and wetlands. The lake system is bounded on the east by the
Withlacoochee River, which drains in a northerly to northwesterly direction, and is bounded to the west by the Brooksville Ridge (fig. 1). The generalized management boundaries for Tsala Apopka Lake extend to U.S. Route 41 (U.S. 41), State Road 200, and State Road 48 (SR 48) to the west, north and south, respectively. Tsala Apopka Lake is divided into three pools that each include multiple lakes. Floral City Pool is farthest to the southeast, is the upstream-most pool, and includes Floral City Lake, Hampton Lake, Tussock Lake, Little Lake (also known as Consuella Lake), and Bradley Lake. Inverness Pool is centrally located and includes Davis Lake, Spivey Lake, Henderson Lake, and Little Henderson Lake. The Hernando Pool is located farthest northwest, is the downstream-most pool, and includes Point Lonesome Lake, Van Ness Lake, Croft Lake, Hernando Lake, Todd Lake, Bellamy Lake, and Dodd Lake. Only the major lakes that remain wet year round are listed here, but there are many smaller lakes and ponds scattered throughout the area that are ephemeral (seasonally wet). This study was primarily concerned with the major Tsala Apopka lakes that are interconnected by the system of structures and canals (fig. 2); smaller lakes and ponds were represented as storage features within the waterbudget calculations.

The largest and deepest of the lakes are along the western side of Tsala Apopka Lake (adjacent to U.S. 41) and most of the wetlands are situated farther to the east (fig. 1). Many of the lakes do not have clearly defined shorelines along their entire perimeter because the deeper open water gradually transitions to shallower wetlands moving from west to east across Tsala Apopka Lake. During wet periods, the wetlands become extensions of the major lakes and it is not uncommon for water to be several feet deep, though this may not be apparent to the casual observer because of the dense emergent vegetation. Fluctuating water stages that cause the shallower wetland areas to submerge or emerge can drastically change the surface area of the lakes. The boundaries of the major lakes that normally stay wet year round and the larger extent of the lakes during flooding are illustrated in figure 1 .

Lakes in central Florida typically indicate the presence of soluble limestone not far below the surface. Where the Ocala Limestone is not too deeply buried, a lacy pattern of innumerable shallow lakes such as Tsala Apopka Lake forms (Cooke, 1945; Stringfield, 1966). Karst terrain, where soluble limestone is at or near the land surface, commonly contains many shallow lakes. Tsala Apopka Lake likely formed in depressions left behind by subsidence sinkholes, a type of sinkhole that forms where limestone is close to the land surface and overlying confining clays are limited in extent or absent (Schiffer, 1996). Subsidence sinkholes form over time as rainwater slowly dissolves limestone. Sediments migrate downward to fill the voids and, over time, the depressions become deep enough that rainwater begins to accumulate in them and a lake is formed. The degree of hydraulic connection of the lake and groundwater can be highly variable depending on the composition of the lake bottom. 


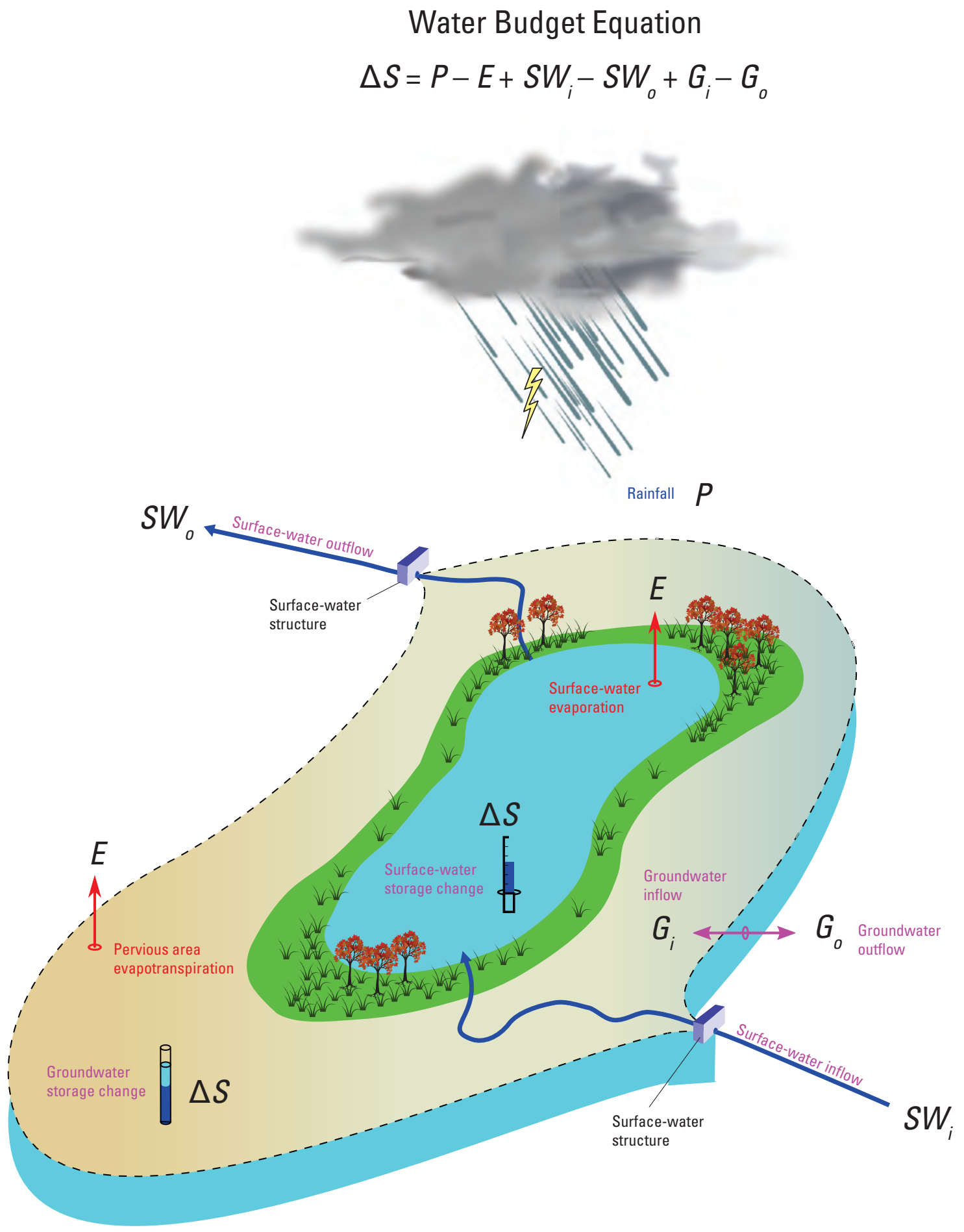

Figure 3. Diagram of idealized water budget for a pool. Change in storage $(\Delta S)$ includes the combined storage change of surface water and groundwater in the surficial aquifer. Evapotranspiration (E) includes surface-water evaporation and evapotranspiration from pervious areas of each pool. 


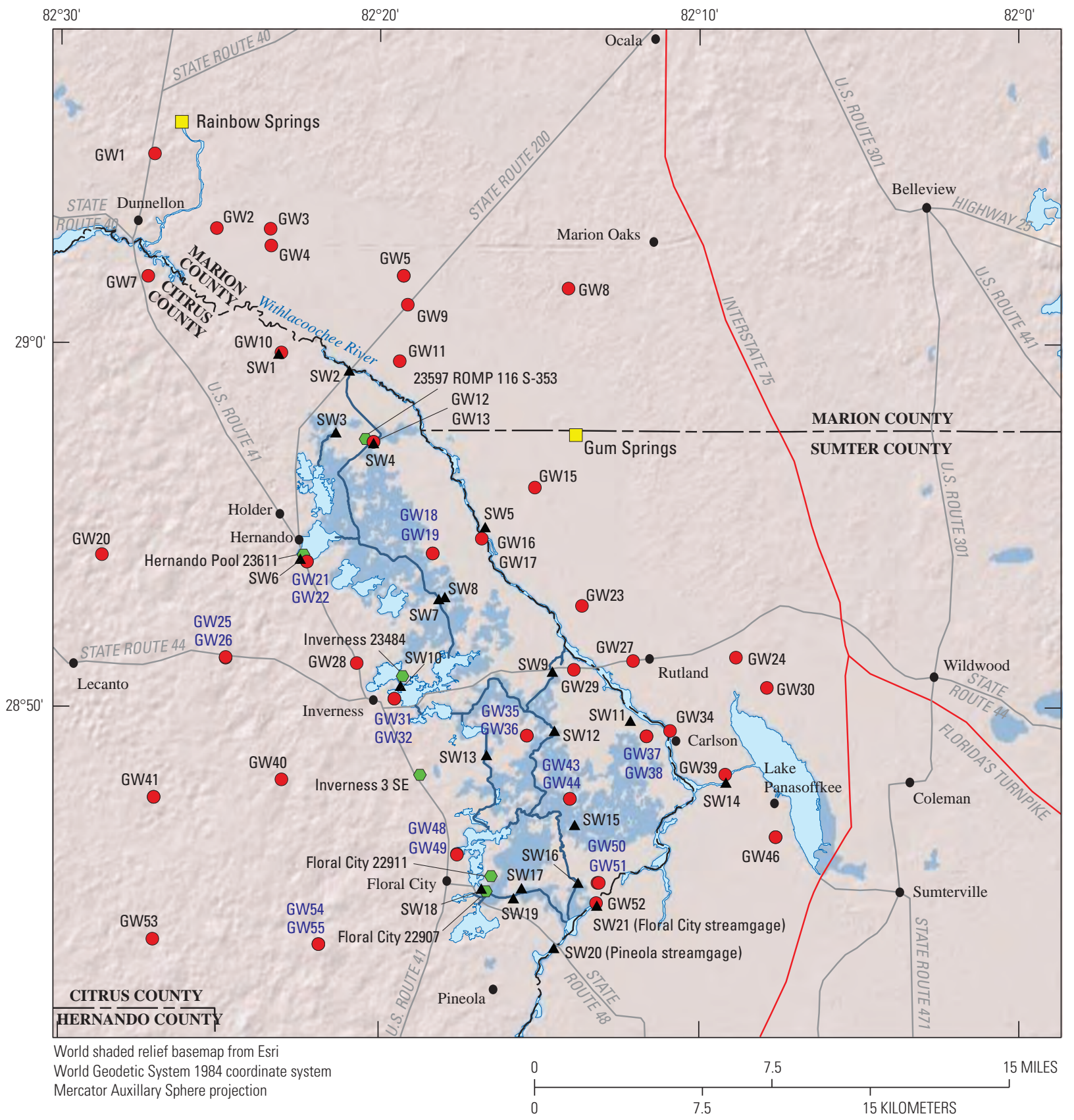

EXPLANATION

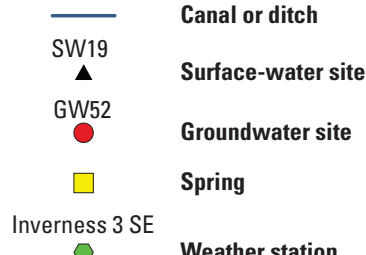

Figure 4. Location of sampling and observation stations in the Tsala Apopka Lake study area. Site codes are cross referenced in table 1 with well site designations and abbreviated names as used by other agencies. Well codes in purple are part of a well pair, with one well finished in the surficial aquifer and another in the Upper Floridan aquifer. 


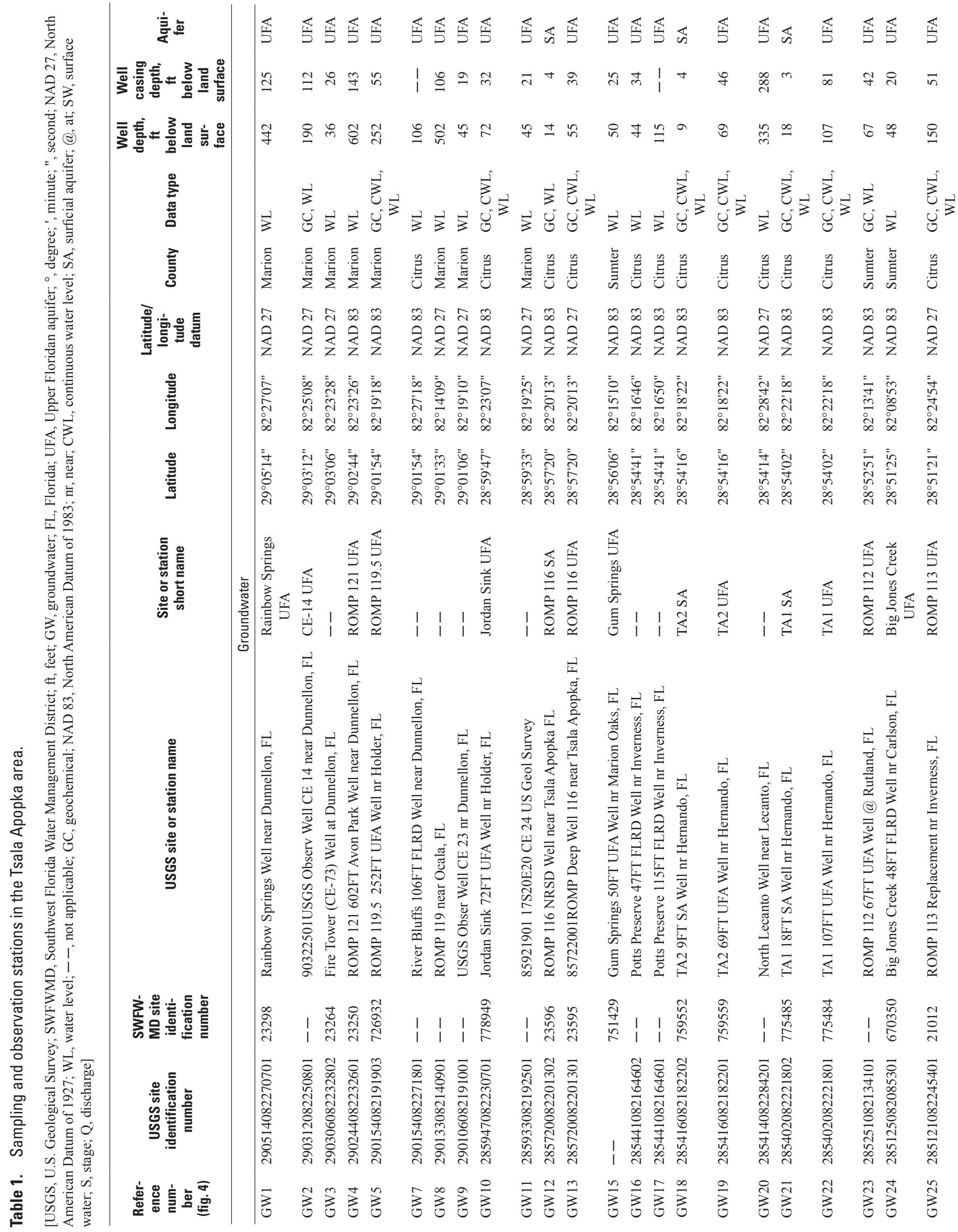




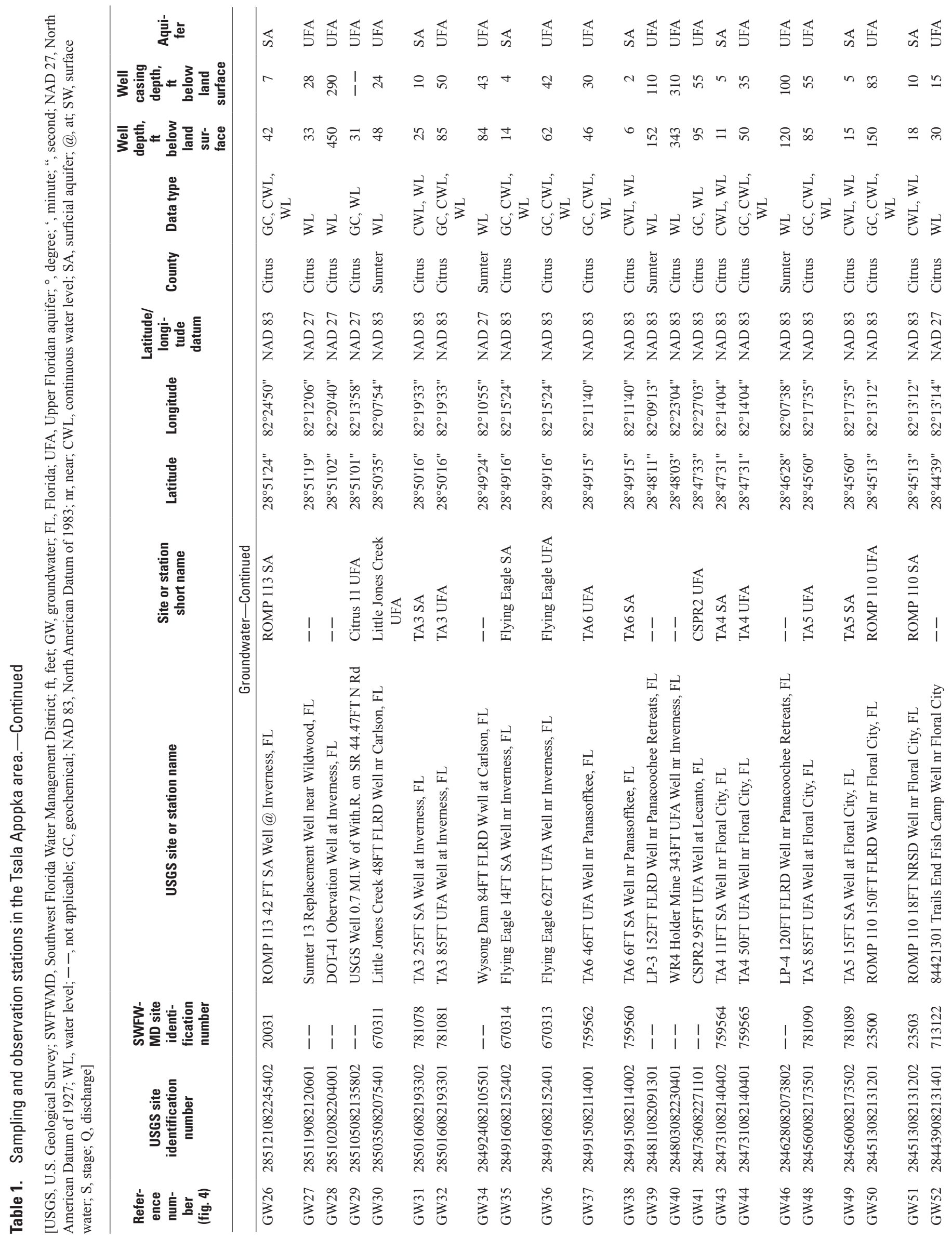




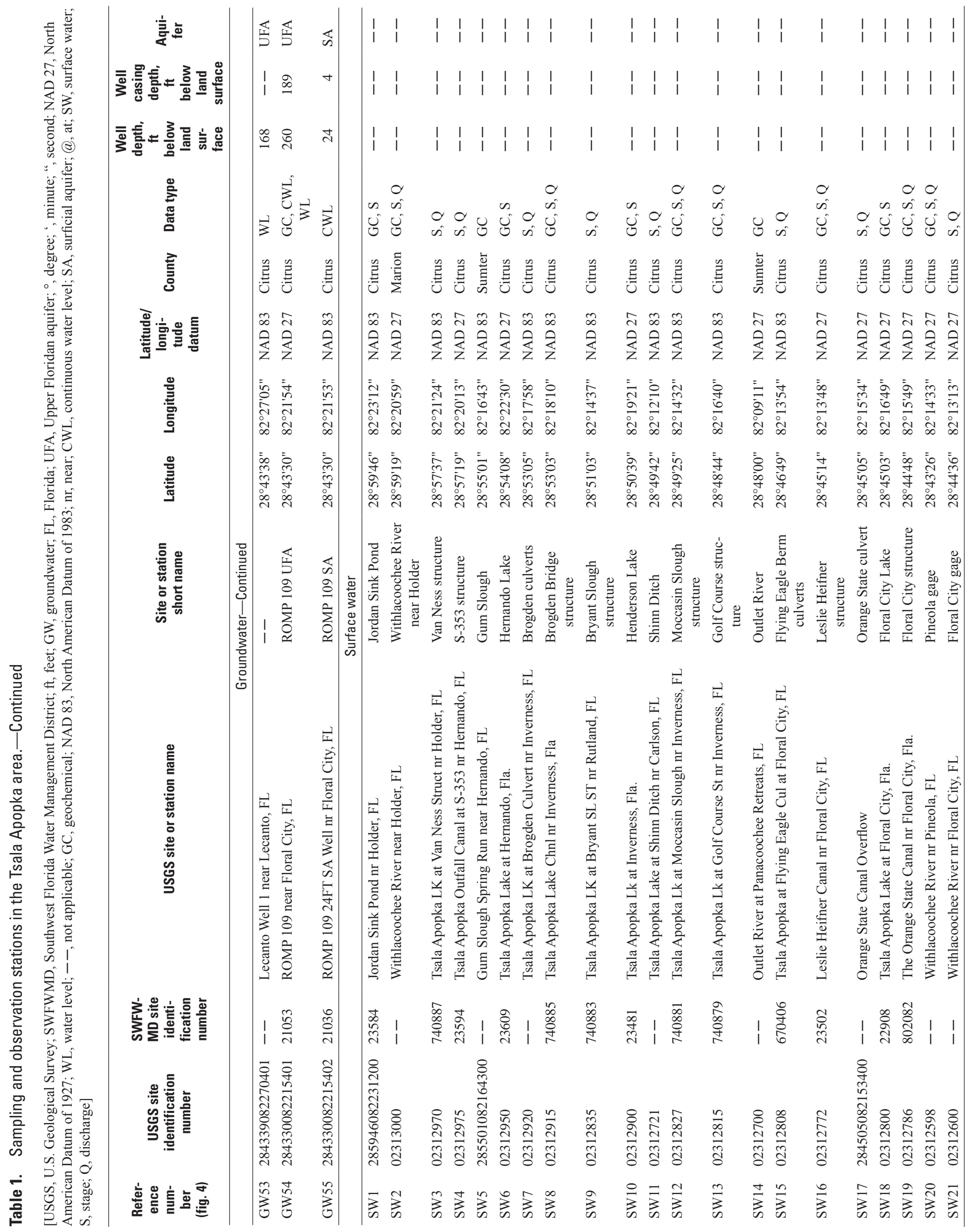




\section{Surface-Water Hydrology}

Flow historically occurred between the Withlacoochee River and Tsala Apopka Lake, when water stages allowed, through a series of wetlands and sloughs. Drainage has been altered as far back as the late 1800s (SWFWMD, 2015b), including the construction of berms and canals, which changed the natural hydrology. The surface-water gradient is low in Tsala Apopka Lake and declines less than 0.5 foot per mile from the south to the north (Florida Fish and Wildlife Conservation Commission, 2008). Today, flow between the river and the pools is managed by structures (fig. 2). When conditions allow, streamflow from the Withlacoochee River is directed through a series of canals into the pools. The magnitude and frequency of this surface-water inflow are dependent on available flows from the river and operating stages within the Tsala Apopka Lake pools. Streamflow from the Withlacoochee River that enters Tsala Apopka Lake is equally distributed between each of the three pools, except when lakes stages are high and additional water from the river is not desirable (SWFWMD, 2010). Reverse flow sometimes occurs for brief periods when river stage drops below lake stage and the control structures are not closed immediately.

Floral City Pool has the most complex surface-flow patterns of the three pools. Flow is affected by canals and structures (fig. 2). Flow from the Withlacoochee River enters Floral City Pool at the southern end of Tsala Apopka Lake through the Orange State and Leslie Heifner canals, which are the largest surface-water inflows to the Tsala Apopka Lake system. Inflows (and outflows) are controlled at these canals by the Floral City and Leslie Heifner structures (figs. 2, 5A, and 5B). The Orange State culvert, a small gated culvert on the Orange State canal near the Floral City structure, can be used to divert water to wetlands in the Floral City Pool through a small secondary channel, but it is typically kept closed. Bradley Lake and Little (Consuella) Lake are connected to the Floral City Pool by way of two small canals that merge southwest of SR 48 before joining the Orange State canal. The Bradley and Consuella structures (fig. 2) are located on the two small canals and are used to maintain stages in Bradley Lake and Little Lake. These lakes become isolated from the Floral City Pool when stages in the two small canals are low or when the gates are closed. The Orange State canal empties into the southern end of Floral City Lake approximately $0.25 \mathrm{mi}$ past the small canal that leads to Bradley Lake and Little Lake.

After flow passes through the Leslie Heifner structure it continues north-northwest through the Leslie Heifner canal for approximately $2 \mathrm{mi}$ before the canal turns sharply to the west (fig. 2). Approximately $1 \mathrm{mi}$ after turning west the Leslie Heifner canal splits. Some of the flow continues west into northeastern Floral City Lake and the rest flows roughly north along the Moccasin Slough Water Conveyance, where flow is controlled by the Moccasin Slough structure (fig. 5C). Golf Course canal exits to the north from Floral City Lake where flow is regulated by Golf Course structure (fig. 5D).
Flow between the Withlacoochee River and the Floral City Pool can also occur through the Flying Eagle Berm culverts (fig. 2). The Flying Eagle Berm culverts are a series of operable riser pipes that are typically closed to conserve water in the Floral City Pool. These culverts are located in the river flood plain approximately $2 \mathrm{mi}$ downstream from the inlets of the Leslie Heifner and Orange State canals. At extreme river stages, water can overtop the berm where these culverts are located and flow unregulated into the Floral City Pool. Shinn Ditch is a shallow canal on the east side of the Floral City Pool. Midway through the study period, Shinn Ditch was hydrologically restored to a natural wetland and no longer acts as a flowing channel. Prior to the restoration, the ditch was approximately $2.5 \mathrm{mi}$ long and under wet hydrologic conditions it flowed northward through a series of wetlands to the Withlacoochee River, but otherwise it was dry or stagnant.

Surface water exits the Floral City Pool to the north through the Moccasin Slough and Golf Course structures (figs. 2, 5C , and 5D) and supplies water to several deep-water lakes, connecting canals, and wetlands within the Inverness Pool. The Brogden Bridge structure (fig. 5E) and Brogden Bridge culverts are on the northern end of the Inverness Pool and pass water downstream to the Hernando Pool. The Bryant Slough structure, on the east side of the Inverness Pool, can divert water back to the Withlacoochee River if stages in the Inverness and Hernando Pools are too high and the river stage is low enough. When Hernando Pool stages are high, the Van Ness structure is opened to allow water to flow northwestward towards Two Mile Prairie, a system of wet prairies and interconnected ditches with high recharge capacity. Because flows through this structure are limited by the natural terrain and available storage within Two Mile Prairie, the S-353 structure (fig. $5 \mathrm{~F}$ ) can also be operated to divert additional water back to the Withlacoochee River through the C-331 canal (fig. 2). The S-353 structure is the only flood control structure within Tsala Apopka Lake and is operated to maintain Hernando Pool stages as needed during high water conditions. All other Tsala Apopka structures are designed for water conservation and are limited in their ability to assist with flood protection. Under normal conditions, water that flows through the aforementioned structures is conserved within the three pools. All structures are controlled and operated by the SWFWMD.

Two USGS real-time streamgages are located near the inflows to Tsala Apopka Lake along the Withlacoochee River (fig. 4 and table 1): Withlacoochee River near Pineola (SW20, U.S. Geological Survey station 02312598) and Withlacoochee River near Floral City (SW21, U.S. Geological Survey station 02312600) streamgages (hereinafter referred to as the Pineola streamgage and the Floral City streamgage). The Pineola streamgage is located approximately $1 \mathrm{mi}$ upstream from the Orange State and Leslie Heifner canals, and the Floral City streamgage is located approximately $1 \mathrm{mi}$ downstream from those canals. Hydrographs of water stages for the Pineola and Floral City streamgages (fig. 6) are similar from 2005 to 2012 (the Pineola streamgage started operation in October 2005). During this period, the stage for the Pineola streamgage 


\section{A. Floral City (downstream view)}

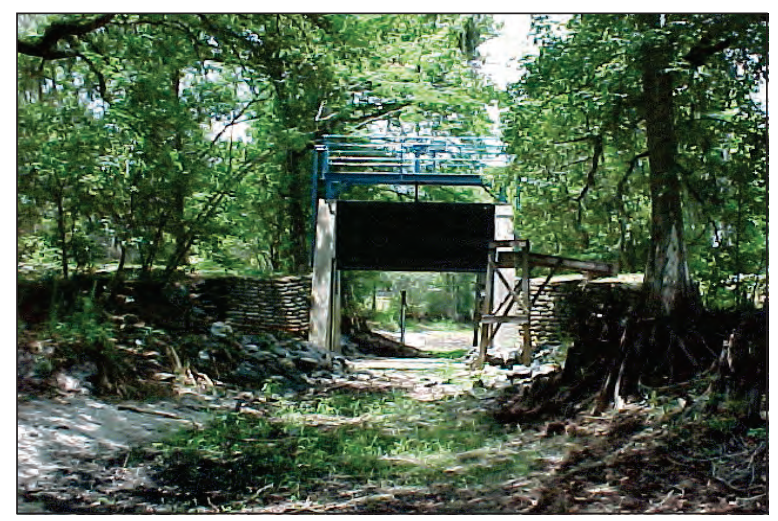

\section{Moccasin Slough (downstream view)}

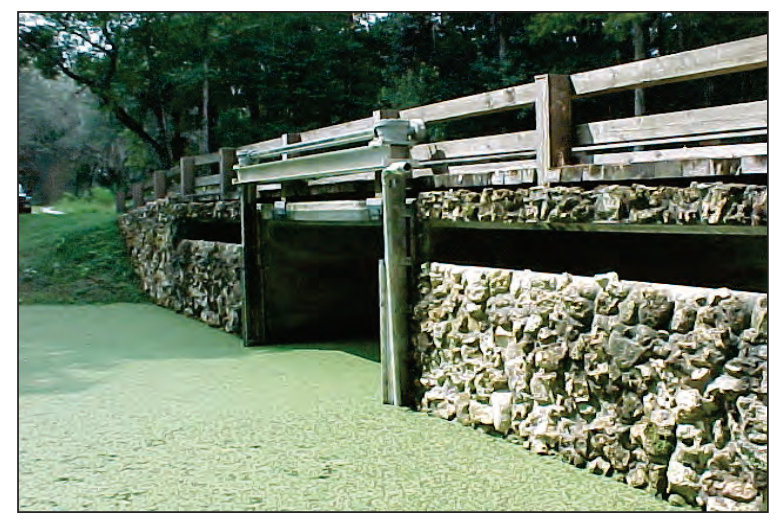

\section{E. Brogden Bridge (downstream view)}

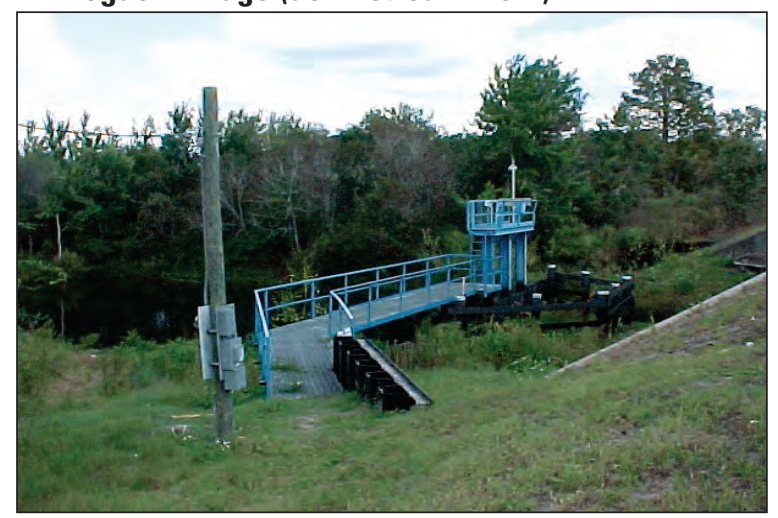

B. Leslie Heifner (downstream view)

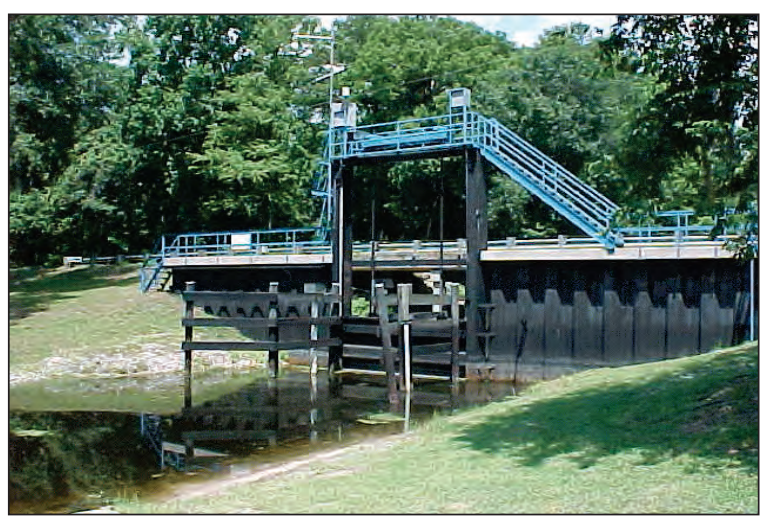

\section{Golf Course (upstream view)}

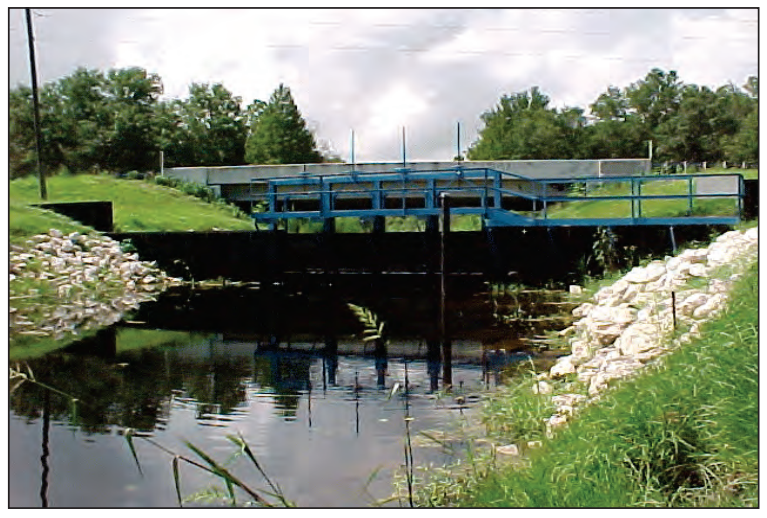

\section{F. S-353 (upstream view)}

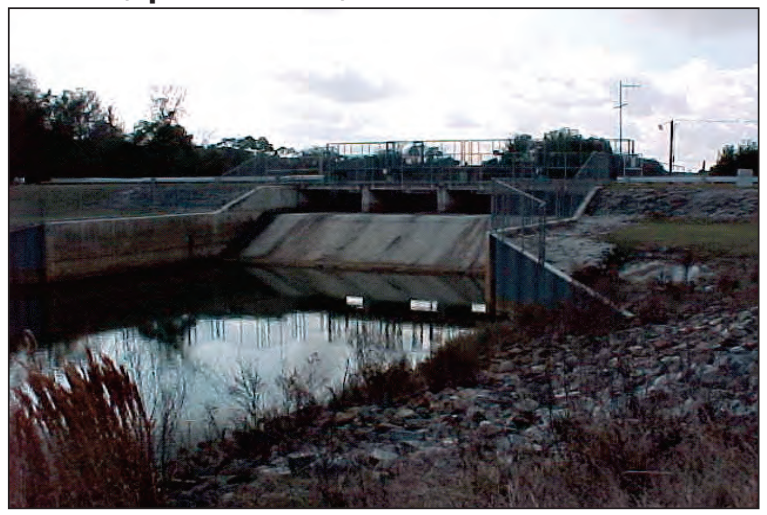

Figure 5. Water-control structures located at Tsala Apopka Lake. A, Floral City; $B$, Leslie Heifner; $C$, Moccasin Slough; $D$, Golf Course; E, Brogden Bridge; F, S-353 (photograph credit: Southwest Florida Water Management District). 


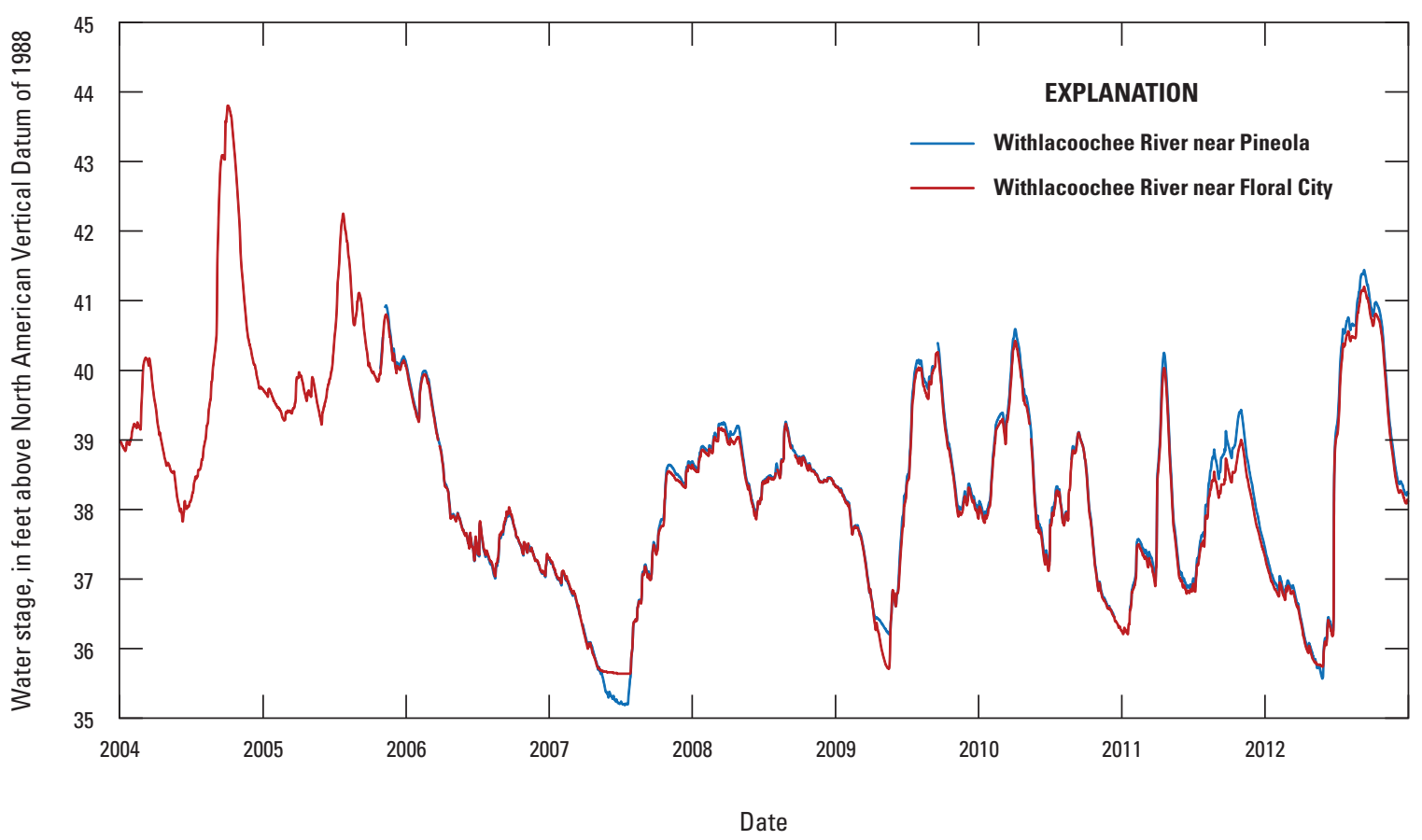

Figure 6. Daily water stages of the Withlacoochee River near Pineola (U.S. Geological Survey station 02312598) and the Withlacoochee River near Floral City (U.S. Geological Survey station 02312600) streamgages, 2004-12 (U.S. Geological Survey, 2017a).

ranged from 41.44 feet (ft) in 2012 to $35.19 \mathrm{ft}$ in 2007, whereas the stage at the Floral City streamgage ranged from $41.20 \mathrm{ft}$ in 2012 to $35.64 \mathrm{ft}$ in 2007. Prior to the installation of the Pineola streamgage, the Floral City streamgage peaked at $43.80 \mathrm{ft}$ in 2004. Diversion of water from the Withlacoochee River to Tsala Apopka Lake is possible when the river stage exceeds that of the Floral City Pool, unless river stage drops below that of the invert elevation at the Leslie Heifner structure. Generally, river water is only available to Tsala Apopka Lake during the wet season when river stages are typically high. The invert elevation at Leslie Heifner structure is approximately $3 \mathrm{ft}$ lower than at the Floral City structure, so the Leslie Heifner structure is the primary control of flow from the river to Tsala Apopka Lake.

The historic availability of river water to the Floral City Pool, based on a comparison of water stages measured at the Floral City streamgage (figs. 4 and 5, table 1, SW21) and in the Floral City Pool at Floral City Lake (SW18) from 1958 to 2015 and during the 2004-12 water-budget period, is shown in figure 7. Availability of river water is characterized by the relationship of the river to the pool. "River too low" occurs when river stage is lower than the lowest gate openings at the structures. "Pool above river" occurs when pool stage exceeds that of river stage. "Pool too high" occurs when pool stage exceeds "high minimum lake levels" established by SWFWMD as part of the minimum flows and levels for Tsala Apopka Lake (SWFWMD, 2007, 2015b). The "high minimum lake level" is required to be equaled or exceeded 10 percent of the time, on a long-term basis; however, staging the lake at the high minimum lake level would not flood any man-made features. For example, in the Floral City Pool, high minimum lake level is $1.8 \mathrm{ft}$ below paved roads (SWFWMD, 2007). During the water-budget period, river water was available from the Withlacoochee River to the Floral City Pool about 18 percent of the time through the Orange State canal and 25 percent of the time through the Leslie Heifner canal, whereas historically (1958-2015) river water has been available about 28 and 31 percent of the time, respectively (fig. 7). The discrepancy in availability during the waterbudget period compared to historic values likely results from the dry conditions during the water-budget period (see "Climate" subsection below). During droughts and the dry season, river stages are sometimes too low for inflow to the pools to occur because river stage is lower than the minimum elevation of the gates at the control structures. River stages were too low to enter the Orange State canal 14 percent of the time from 2004 to 2012 and 7 percent of the time from 1958 to 2015 , whereas river stage never fell below the gates on the Leslie Heifner canal during the same periods.

From 2004 to 2012, the pool stage was either above the river stage or the river was too low to flow into Tsala Apopka Lake 53 percent of the time through the Orange State canal and 46 percent of the time through the Leslie Heifner canal. From 1958 to 2015, no flow was available through the Orange 


\section{A. 2004-12}

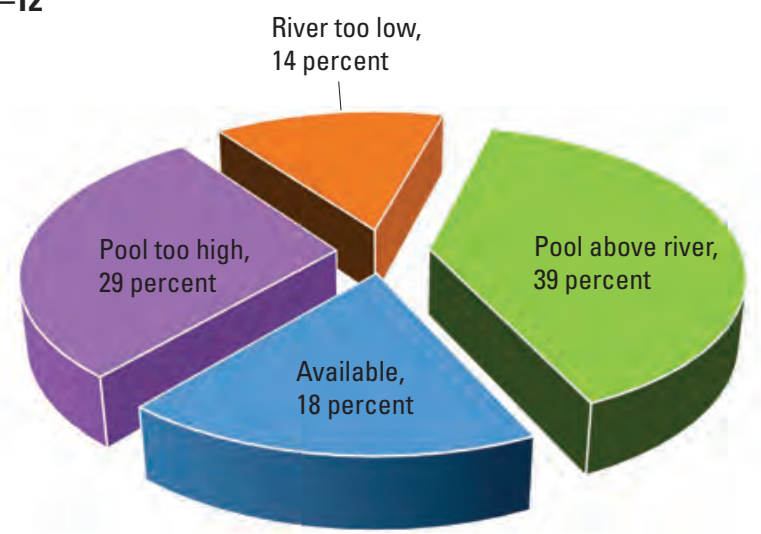

Orange State Canal

\section{B. 1958-2015}

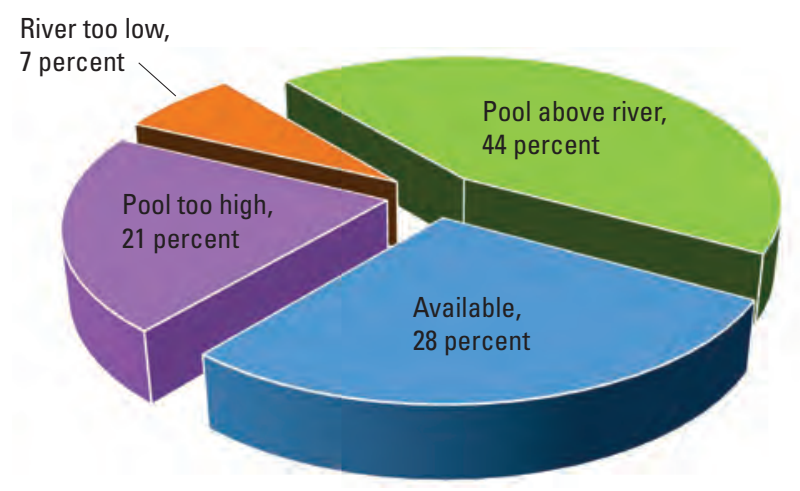

Orange State Canal

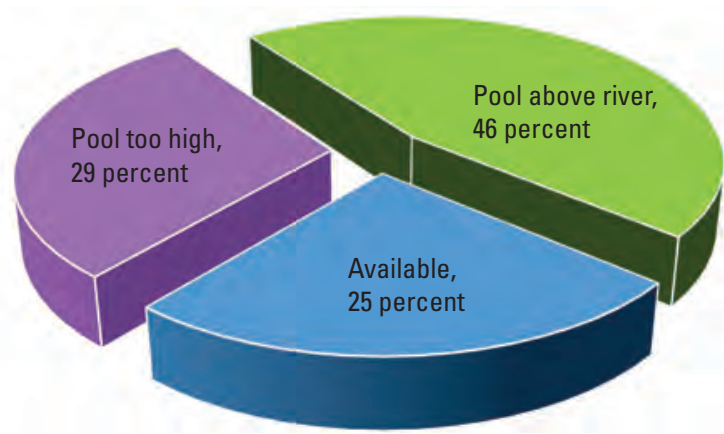

Leslie Heifner Canal

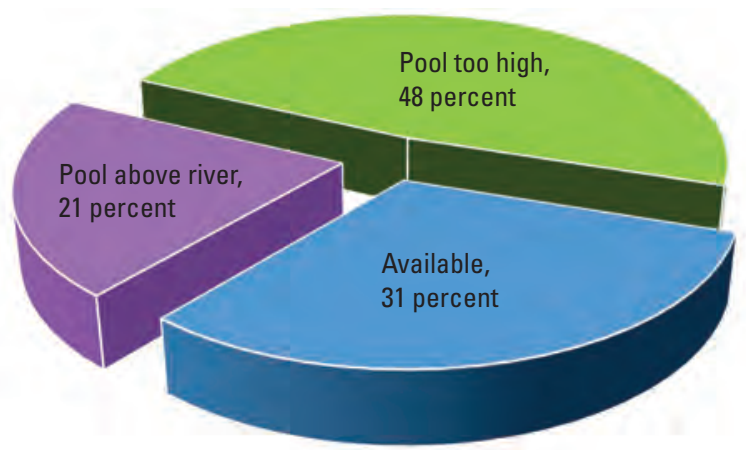

Leslie Heifner Canal

Figure 7. Availability of Withlacoochee River inflow to the Floral City Pool through the Orange State and Leslie Heifner canals. $A, 2004-12$ and $B, 1958-2015$.

State and Leslie Heifner canals 51 and 48 percent of the time, respectively, because the pool stage was either above the river stage or the river stage was lower than the structure invert. At the Orange State and Leslie Heifner canals, the pools exceeded high minimum lake levels 29 percent of the time from 2004 to 2012, and 21 percent of the time from 1958 to 2015. A detailed discussion of the minimum flows and levels for Tsala Apopka Lake was published by the SWFWMD $(2007,2010)$.

\section{Climatic, Physiographic, Geologic, and Hydrogeologic Setting}

Characteristics of the climatic, physiographic, and geologic settings of the Tsala Apopka Lake area have been included in the studies by Vernon (1951), White $(1958,1970)$, Spencer (1984), Fernald and Purdum (1998), Green and others (2011), and Williams and others (2011). The hydrogeologic framework of the Floridan aquifer system was described by Miller (1986), Arthur and others (2008), HydroGeoLogic (2013), and Williams and Kuniansky (2015). The hydrology of lakes in the Tsala Apopka Lake area has been described by Rutledge (1977) and Bradner (1988). Attardi (1983) described the hydrology and plant communities of Tsala Apopka Lake, and Buickerood and others (1990) characterized the hydrology, water quality, and biology of the lake system. Wharton and Dooris (2005) described the pre-settlement surface-water features and vegetation of Tsala Apopka Lake. The Florida Fish and Wildlife Conservation Commission (2008) described the sediment and vegetation of the lake system. Dooris (1978) and Romie (2000) characterized the water quality of Tsala Apopka Lake. Rating curves for the structures on Tsala Apopka Lake were developed by Harrison and others (1981). The SWFWMD (2014a, 2015b) developed a surfacewater flow model for the Withlacoochee River watershed that includes Tsala Apopka Lake. 


\section{Climate}

The Tsala Apopka Lake area has warm, humid summers and cool, dry winters associated with a subtropical climate (Fernald and Purdum, 1998). The mean annual air temperature for 1981-2010 climate normal at the National Oceanic and Atmospheric Administration (NOAA) Inverness $3 \mathrm{SE}$ weather station (fig. 4, station number 084289) is approximately 70 degrees Fahrenheit $\left({ }^{\circ} \mathrm{F}\right)$, with summer air temperatures that occasionally rise above $90^{\circ} \mathrm{F}$, and winter temperatures that occasionally fall below $45^{\circ} \mathrm{F}$ (table 2 , National Oceanic and Atmospheric Administration National Centers for Environmental Information, 2015a). The rainy season lasts from June through September, with rain events mostly in the form of intense localized thunderstorms and occasional tropical storms.

Based on rainfall data recorded at the Inverness $3 \mathrm{SE}$ weather station for 1930-2014 (fig. 8), mean annual rainfall was 54 inches (in.) and ranged from a minimum of 36 in. in 1999 to a maximum of 87 in. in 1960 (National Oceanic and Atmospheric Administration, National Centers for Environmental Information, 2015b). Conditions during the study period were dry; the rainfall deficit, relative to the 1930-2014
Table 2. Range of seasonal air temperature at the National Oceanic and Atmospheric Administration Inverness 3 SE weather station (084289) from 1981 to 2010 (National Oceanic and Atmospheric Administration, 2015a).

$\left[{ }^{\circ} \mathrm{F}\right.$, degree Fahrenheit $]$

\begin{tabular}{lccc}
\hline Season & $\begin{array}{c}\text { Minimum } \\
\text { temperature } \\
\left({ }^{\circ} \mathbf{F}\right)\end{array}$ & $\begin{array}{c}\text { Average } \\
\text { temperature } \\
\left({ }^{\circ} \mathbf{F}\right)\end{array}$ & $\begin{array}{c}\text { Maximum } \\
\text { temperature } \\
\left({ }^{\circ} \mathbf{F}\right)\end{array}$ \\
\hline Annual & 57.6 & 70.3 & 83.0 \\
Winter & 44.0 & 58.0 & 72.1 \\
Summer & 70.4 & 81.1 & 91.9 \\
Spring & 55.1 & 69.2 & 83.3 \\
Autumn & 60.6 & 72.6 & 84.6 \\
\hline
\end{tabular}

mean, exceeded 26 in. in the Tsala Apopka Lake area for the years 2004-12 (fig. 9). Decades during the period 1930-2009 (such as 1930-39, 1940-49, through 2000-09) had mean annual rainfall deficits during four decades with the greatest deficit of 50.3 in. occurring during 1990-99. Annual rainfall records at the Inverness $3 \mathrm{SE}$ weather station indicate no

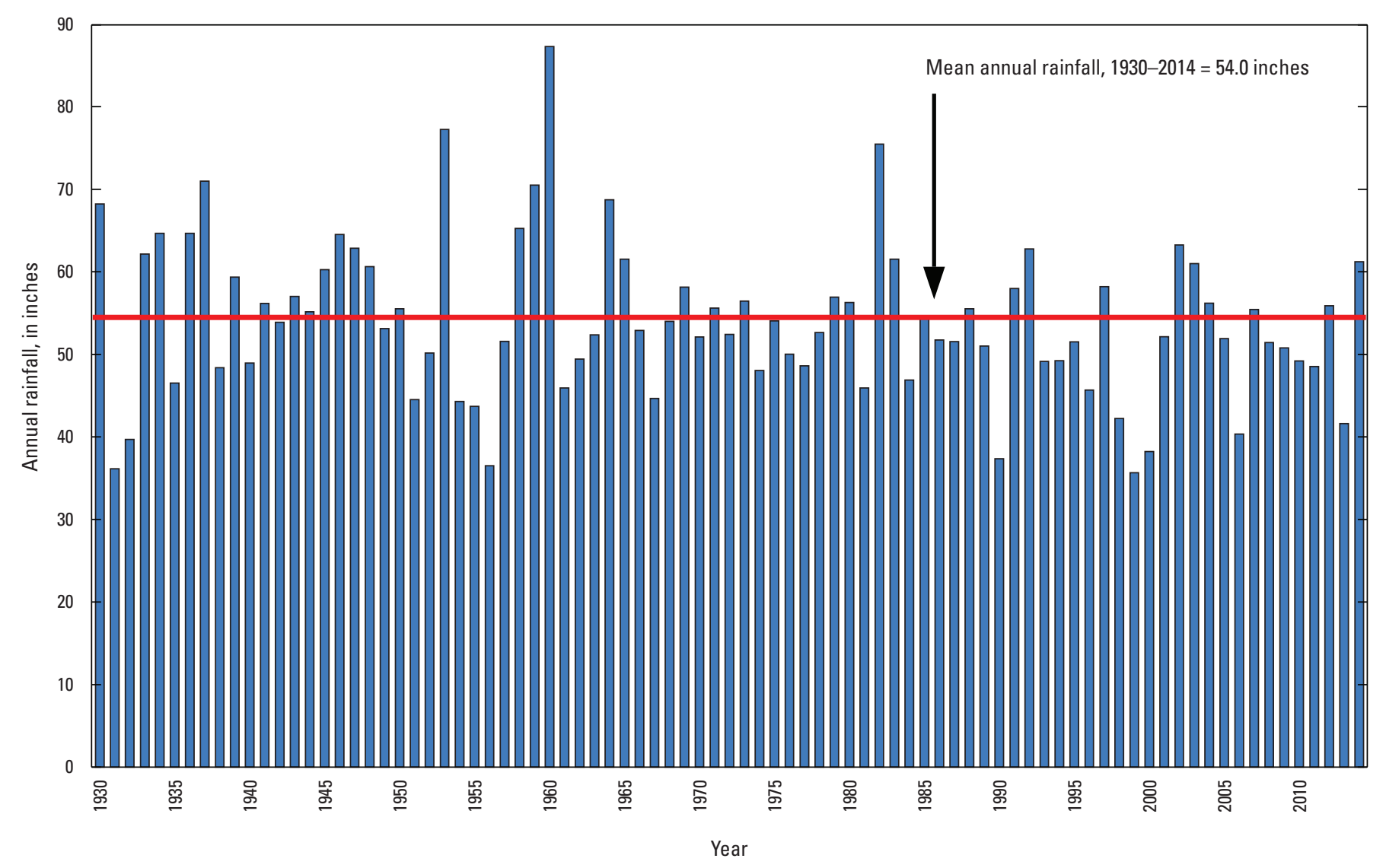

Figure 8. Total annual rainfall at the National Oceanic and Atmospheric Administration Inverness 3 SE weather station (station number 084289) from 1930 to 2014 (National Oceanic and Atmospheric Administration, 2015b). 


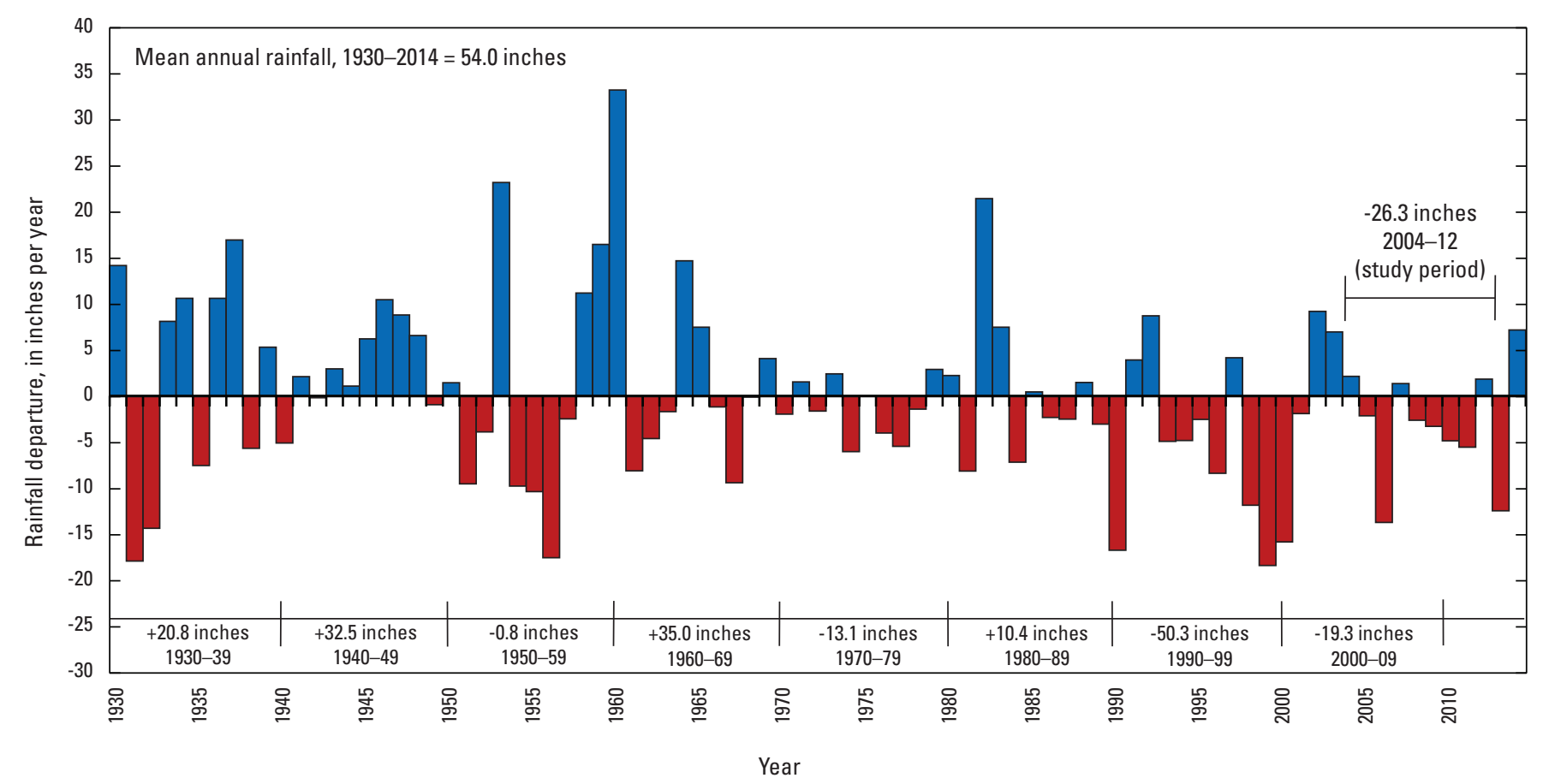

Figure 9. Annual rainfall departure at Tsala Apopka Lake from 1930 to 2014 at the National Oceanic and Atmospheric Administration Inverness 3 SE weather station (station number 084289, National Oceanic and Atmospheric Administration, 2015b).

significant trend from 1931 to 1970 and a significant downward trend from 1971 to 2010 (computed on the basis of the Kendall's tau non-parametric test [Kendall, 1938]). From 2004 to 2012, 6 of 9 years had annual rainfall deficits. In 2006, the deficit was severe with annual rainfall almost 14 in. below normal. Surplus annual rainfall during the same period tended to be slight, with 2004 having the greatest surplus of about 2 in.

\section{Physiography}

Tsala Apopka Lake is located within the Western Valley physiographic region (White, 1970) (fig. 10). The Western Valley parallels the west coast of Florida from north of Gainesville to south of Zephyrhills and is bounded by the Brooksville Ridge to the west and various distinct upland areas to the east, including the Sumter and Lake Uplands (White, 1970). Tsala Apopka Lake and much of the Withlacoochee River are located within a subregion of the Western Valley called the Tsala Apopka Plain. White (1958) theorized that the Tsala Apopka Plain is a relict feature of a much larger lake and river system that originally flowed southward into the Hillsborough River and, ultimately, into Tampa Bay (fig. 1). The Brooksville Ridge formed the western boundary of this large lake and river system. As flowing groundwater dissolved the limestone bedrock, the Dunnellon Gap formed across the Brooksville Ridge (Faulkner, 1973). Surface-water flow in the river system then reversed and began flowing northward along the route of the modern-day Withlacoochee River, which flows west through the Dunnellon Gap before emptying into the Gulf of Mexico (White, 1958).

To the west of the Tsala Apopka Plain is the Brooksville Ridge (fig. 10), which has the most undulating surface of any terrain feature of comparable size in peninsular Florida (White, 1970). Elevations of the Brooksville Ridge are as high as $250 \mathrm{ft}$ above the North American Vertical Datum of 1988 (NAVD 88) but can vary from 70 to $250 \mathrm{ft}$ within short distances.

\section{Geology}

The geology of the Tsala Apopka Lake area is dominated by limestone strata and associated karst terrain. Stratigraphic units in the study area span the Eocene through the Holocene ages and include, from oldest to youngest, the Eocene-age Avon Park Formation and Ocala Limestone, Miocene-age Hawthorn Group, and Tertiary-age and Quaternary-age undifferentiated surficial deposits. The stratigraphic units, hydrogeologic units, and generalized lithologic descriptions are summarized in figure 11, and a generalized geologic map and geologic cross sections (Green and others, 2011) are presented in figures 12 and 13, respectively. Green and others (2011) indicate that the geologic map and associated geologic cross sections may disagree when depicting units exposed at the 


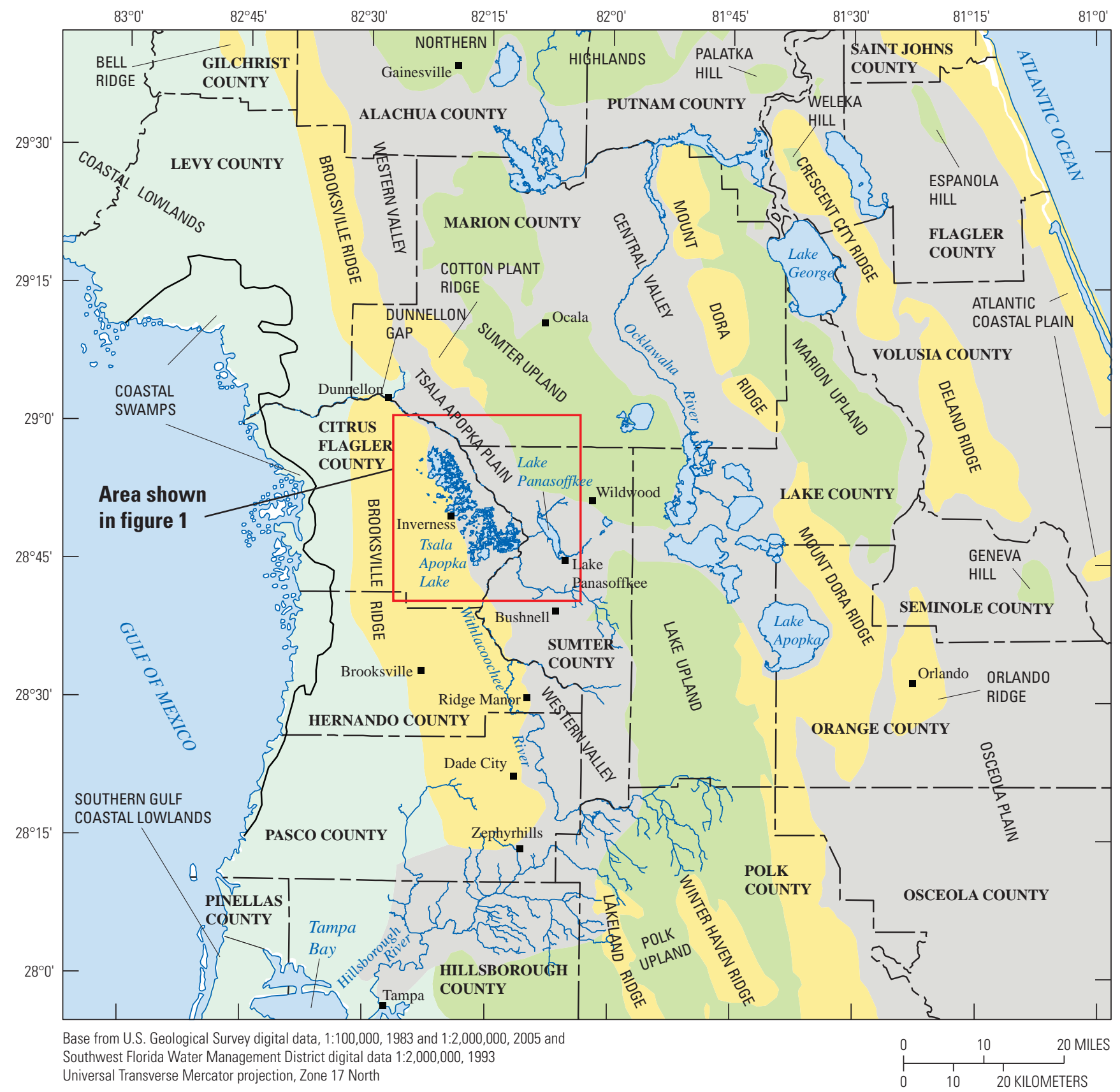

EXPLANATION

Physiographic landform

Lowland/other

Ridge

Upland

Valley or plain

Figure 10. Physiographic regions of central Florida (White, 1970). 


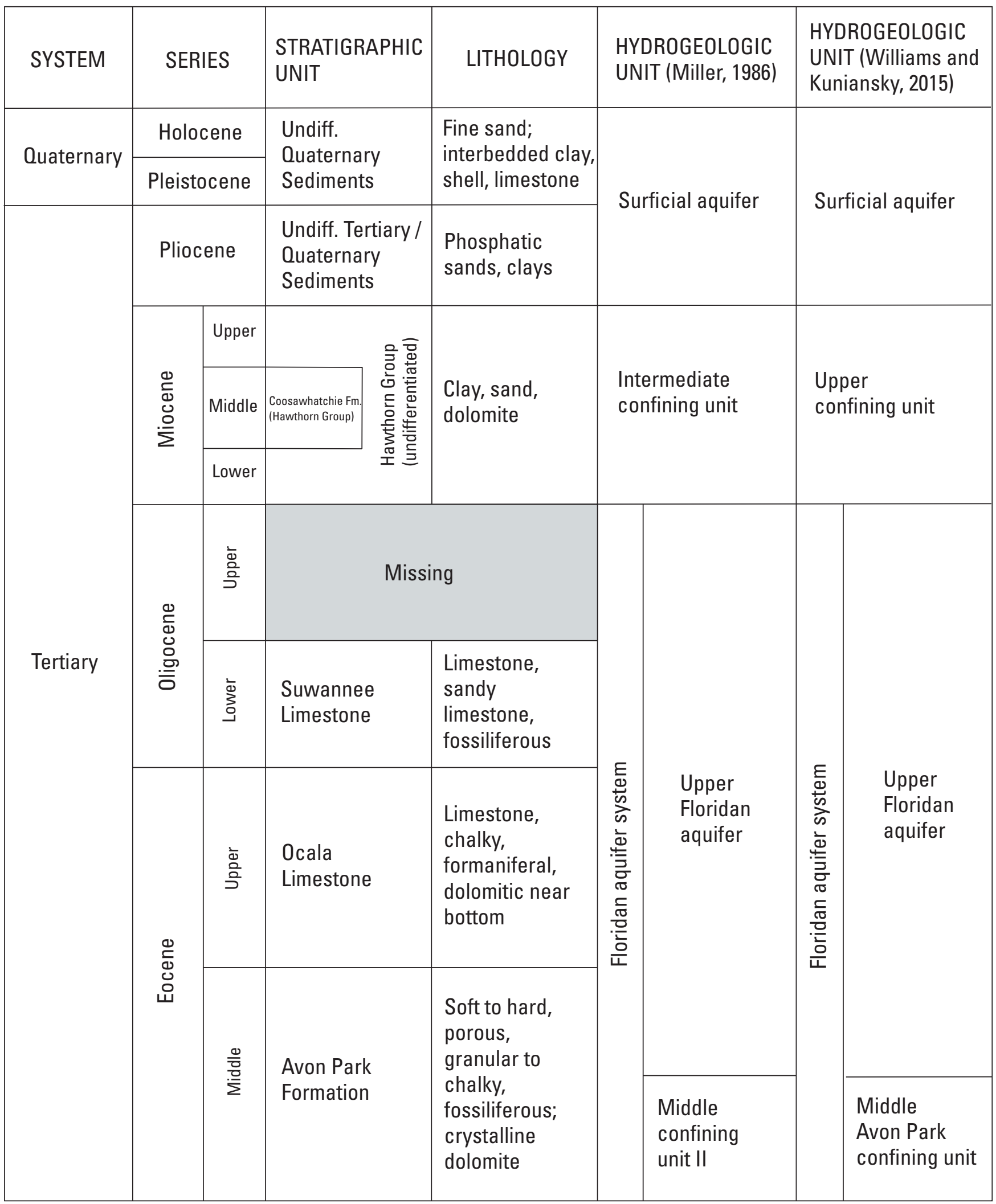

Figure 11. Relation of stratigraphic and hydrogeologic units in the Tsala Apopka Lake study area (modified from Miller, 1986, and Williams and Kuniansky, 2015). 


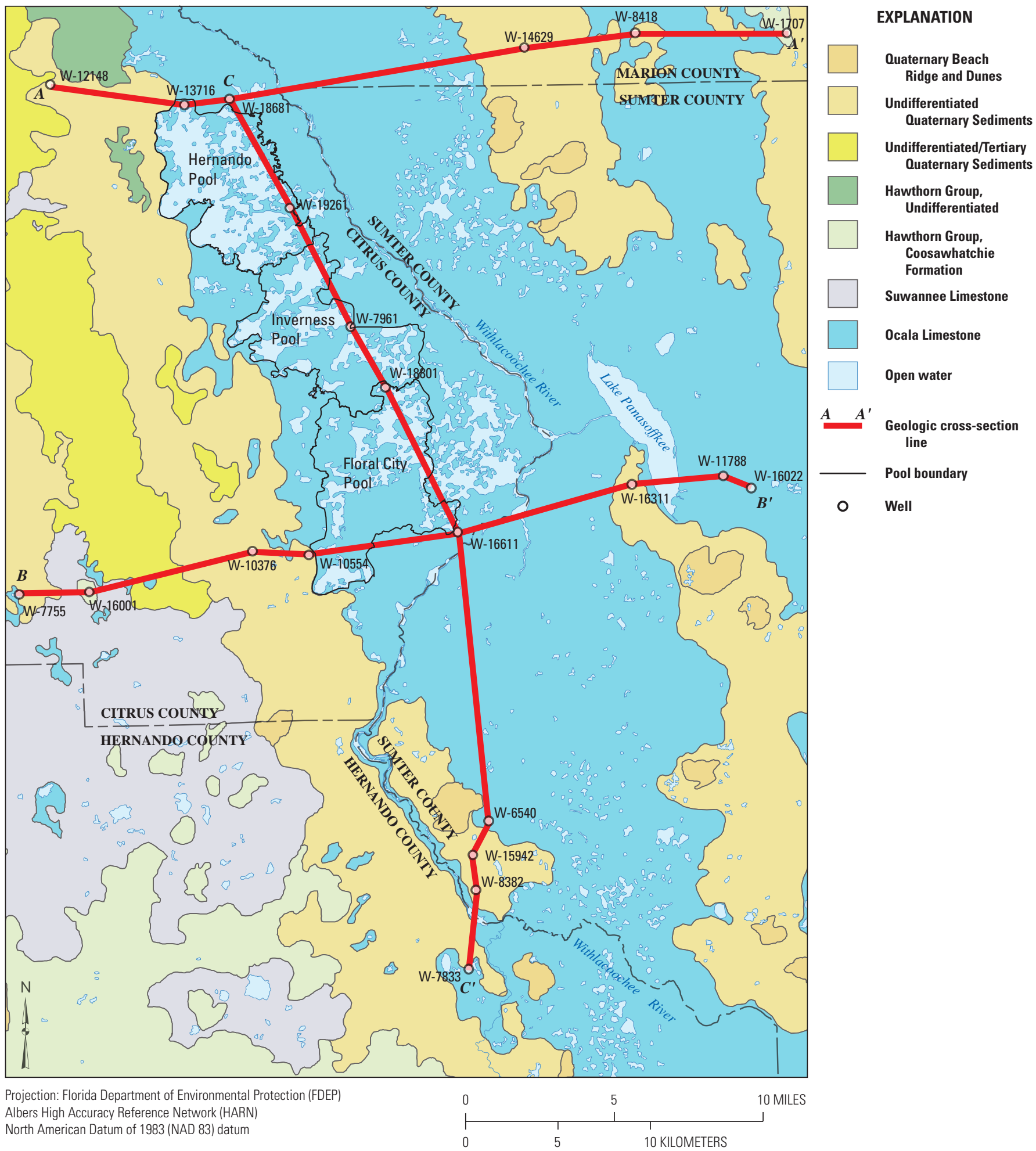

Figure 12. Geology of the Tsala Apopka Lake area (modified from Green and others, 2011). 
A

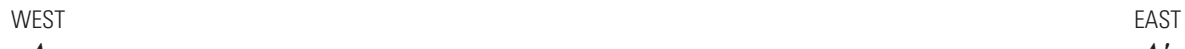

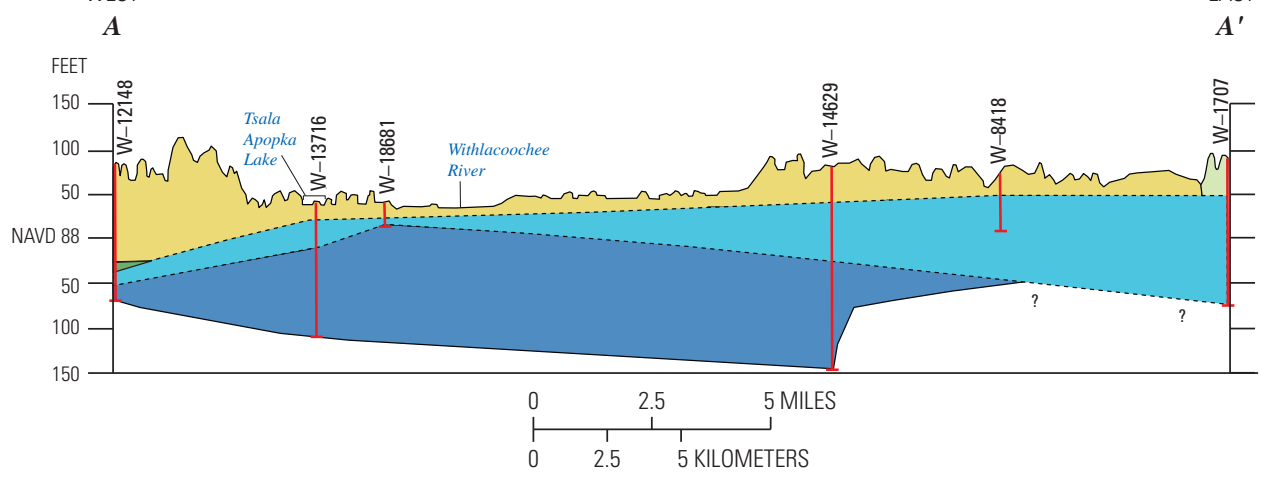

B

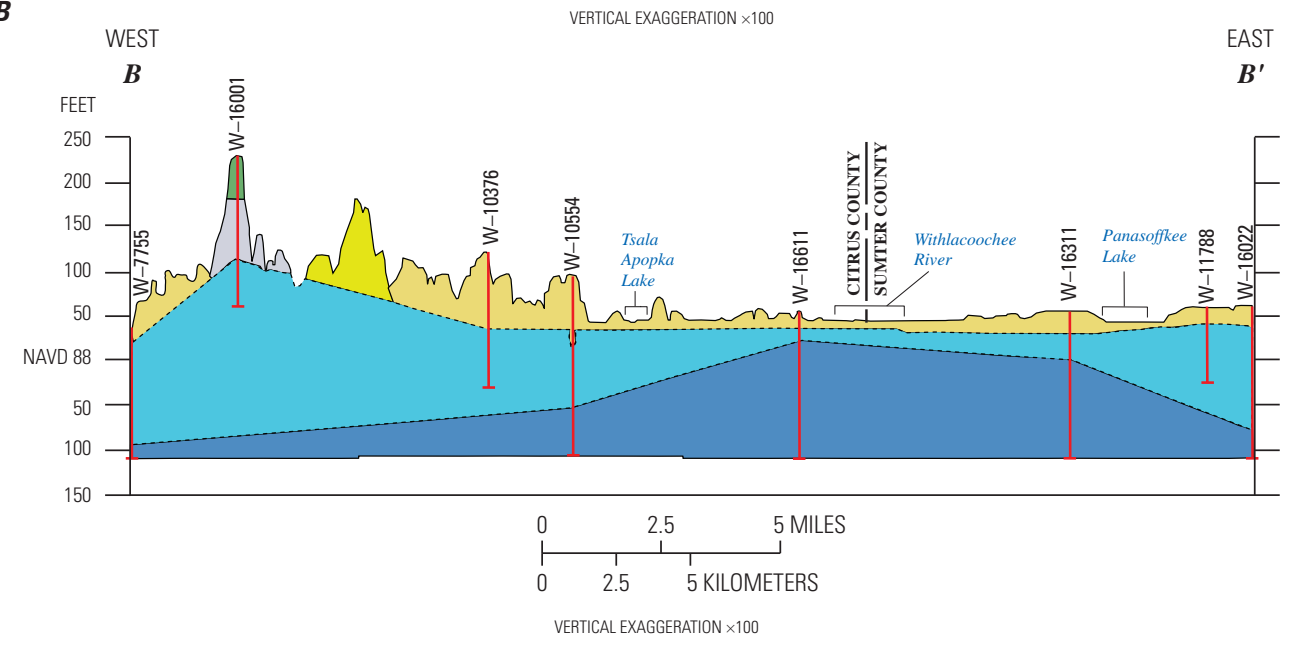

'

AST

A

$c$

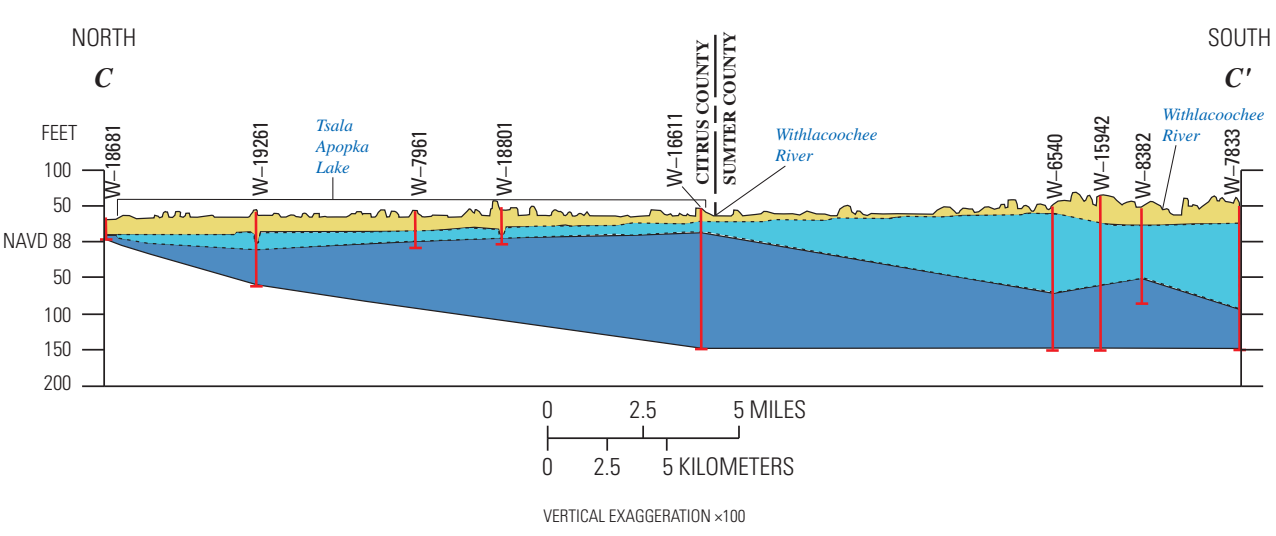

Figure 13. Geologic cross sections showing the geology of the Tsala Apopka Lake area (modified from Green and others, 2011). 
surface, as a result of not portraying undifferentiated sediments on the geologic map unless they are thicker than $20 \mathrm{ft}$. Cross sections will include undifferentiated sediments, and contacts between wells are based on straight-line projections, which can result in apparent thicknesses on the cross section that are not supported by field evidence.

The Middle Eocene-age Avon Park Formation is the oldest and deepest unit that is included in the study area (fig. 13). The formation mostly consists of dolostone and limestone that are cream to light-brown in color. Porosity in the upper Avon Park Formation is primarily intergranular, but there are also frequent pin-point size vugs and fossil molds that increase porosity (LaRoche, 2012). The middle and lower parts of the Avon Park Formation consist of dolomitic limestone that includes intergranular, intercrystalline, or interbedded gypsum, anhydrite, and chert. In the vicinity of Tsala Apopka Lake, the top of the Avon Park Formation is as shallow as $20 \mathrm{ft}$ below land surface (bls), though the top of the unit is typically deeper, as much as $142 \mathrm{ft}$ bls, east and west of the lakes (fig. 13C). Exploratory drilling performed by the SWFWMD, in the northern part of the study area at the Regional Observation and Monitoring-Well Program (ROMP) 119.5 well site, penetrated the base of the Avon Park Formation at a depth of 1,234 ft bls (LaRoche, 2012).

Overlying the Avon Park Formation is the Late Eoceneage Ocala Limestone. Recrystallization of the Ocala Limestone often makes the contact between these units difficult to identify, as does the fact that the contact is a disconformity (LaRoche, 2012). The Ocala Limestone is highly karstified, very fossiliferous, and white to cream in color. Porosity is intergranular and moldic (LaRoche, 2012). The Ocala Limestone is present throughout the study area, except in isolated locations, such as in sinkholes, where it is absent because of chemical and mechanical weathering (Williams and others, 2011). In the lowlands near Tsala Apopka Lake, the top of the Ocala Limestone ranged from 10 to $52 \mathrm{ft}$ bls at seven well sites installed by the SWFWMD (Dawson, 2007; Horstman, 2011). The thickness of the limestone is highly variable throughout the study area. Core data collected by the Florida Geological Survey indicate that the Ocala Limestone is 0-198 ft thick, but it is generally thin near Tsala Apopka Lake, approximately $25 \mathrm{ft}$ thick or less (Williams and others, 2011).

The Ocala Limestone is mostly overlain by Miocene-age through Holocene-age sediments. These sediments include the undifferentiated Hawthorn Group and the undifferentiated Tertiary-age and Quaternary-age sediments (figs. 11, 12, and 13). In many parts of the region these sediments overlie the Lower Oligocene-age Suwannee Limestone, but in the vicinity of Tsala Apopka Lake the Suwannee Limestone is almost entirely missing, leaving the Ocala Limestone as the most common uppermost limestone in the area (Williams and others, 2011). The Miocene-age Hawthorn Group sediments in the study area are either undifferentiated or part of the Coosawhatchie Formation. The undifferentiated Hawthorn Group sediments vary in color from light olive gray and blue gray in areas where they are unweathered to reddish brown to reddish gray in weathered sections. These sediments consist of clayey sands, silty clays, and clays (Williams and others, 2011). The Coosawhatchie Formation, which is rare in the vicinity of Tsala Apopka Lake, is light gray to olive gray in color and consists of variably clayey sand to sandy, silty clay. The Tertiary-age and Quaternary-age undifferentiated sediments that overlie the Coosawhatchie Formation, where present, are white to gray to blue-green coarse-grained sands, sandy clays, clayey sands, and mixtures of clay and organics (Williams and others, 2011).

The thickness of the Miocene-age through Holoceneage sediments in the study area is highly variable. It is difficult to differentiate the Hawthorn and undifferentiated Tertiary-age and Quaternary-age sediments. Many well logs list the overburden above the uppermost limestone simply as "undifferentiated sands and clays." The undifferentiated sands and clays varied from 10 to $36 \mathrm{ft}$ thick at sites TA2 UFA, TA3 UFA, TA4 UFA, TA6 UFA, and Flying Eagle UFA (fig. 4 and table 1, GW19, GW32, GW44, GW37, and GW36, respectively), all wells installed by SWFWMD in the lowlands near Tsala Apopka Lake. At sites TA1 UFA and TA5 UFA (GW22 and GW48, respectively, on fig. 4 and table 1) there was enough distinction to separate the undifferentiated sediments from the Hawthorn Group (Dawson, 2007; Horstman, 2011). The Hawthorn Group sediments were 34 and $14 \mathrm{ft}$ thick, whereas the undifferentiated sediments were 18 and $30 \mathrm{ft}$ thick, respectively.

\section{Hydrogeology}

The hydrogeologic units (fig. 11) in the study area are described by Williams and Kuniansky (2015) and include in descending order, the surficial aquifer, upper confining unit, and Floridan aquifer system. The Floridan aquifer system is further divided into the Upper Floridan aquifer, middle Avon Park confining unit, and the Lower Floridan aquifer, which is not shown on figure 11. To align with SWFWMD studies for this region, the hydrogeologic nomenclature outlined in Miller (1986) is used henceforth instead of the conventions set forth by Williams and Kuniansky (2015). The upper confining unit and middle Avon Park confining unit are the only units affected by this change in convention (fig. 11). The upper confining unit hereafter is referred to as the intermediate confining unit and the middle Avon Park confining unit hereafter is referred to as the middle confining unit II.

\section{Surficial Aquifer}

The surficial aquifer consists of Tertiary-age and Quaternary-age undifferentiated sediments and is the uppermost hydrostratigraphic unit in the study area, except in localized areas where Ocala Limestone or Hawthorn Group clays are exposed at the land surface (figs. 11, 12, and 13). The surficial aquifer is unconfined and permeable with local less-permeable clay layers and is contiguous with the land surface. As such, 
the water table in the surficial aquifer generally mimics the topography of land surface (Arthur and others, 2008). Areas where the surficial aquifer is continuously saturated at the surface are assumed to be underlain by the less permeable sediments of the intermediate confining unit (HydroGeoLogic, 2013). Intermittent saturation can occur when the infiltration rate at land surface exceeds the recharge rate to the Upper Floridan aquifer, typically during the wet season. The surficial aquifer is not typically used as a source of water in the study area, but hydrologically this unit is important because it acts as a "source-sink" bed (Miller, 1986) for water before it either recharges the Upper Floridan aquifer or discharges to sections of the Withlacoochee River, Tsala Apopka Lake, Lake Panasoffkee (fig. 1), or other surface-water bodies.

In the vicinity of Tsala Apopka Lake the surficial aquifer is thin, usually no more than $20 \mathrm{ft}$ thick (plate 2 of Green and others, 2011). In the lowlands, the water table is typically less than $15 \mathrm{ft}$ bls. In the highlands, west of Tsala Apopka Lake along the Brooksville Ridge, sediments in the surficial aquifer become thicker, as much as $130 \mathrm{ft}$ thick, and depths to the water table are also correspondingly deeper (Williams and others, 2011). Along the Brooksville Ridge, a thin veneer of siliclastics overlies sandy clays. In the southern one-half of the Brooksville Ridge, corresponding to sections in Pasco and Hernando Counties, the clays are relatively intact and when the sediments are saturated, a perched water table can result. In the northern one-half of the ridge, west of Tsala Apopka Lake in Citrus County, the clays are sufficiently breached so that the sediments are almost always unsaturated, except for brief periods following heavy rains.

\section{Intermediate Confining Unit}

The intermediate confining unit is laterally discontinuous in the study area (Williams and others, 2011). The intermediate confining unit can act as a semi-confining unit in localized areas within the study area, but generally the unit is so breached by karst activity and erosion that the underlying Upper Floridan aquifer is effectively unconfined. Semi-confined conditions result in areas where the intermediate confining unit is thin or leaky. When karst activity is common and regional in scope, unconfined conditions can result. The intermediate confining unit is assumed to be absent or provides little or no confinement in areas where the hydraulic head difference between the surficial aquifer and underlying Upper Floridan aquifer is less than $0.5 \mathrm{ft}$ (HydroGeoLogic, 2013).

The intermediate confining unit ranges from 4 to $34 \mathrm{ft}$ in thickness at seven well sites located in the lowlands near Tsala Apopka Lake (Dawson, 2007; Horstman, 2011). It is possible that some of the clays at these sites belong to the undifferentiated Tertiary-age and Quaternary-age sediments and not the intermediate confining unit (Hawthorn Group). It is difficult to differentiate the clays of the Hawthorn Group from those of the undifferentiated Tertiary-age and Quaternary-age sediments based on drill cuttings alone. The Hawthorn Group sediments are heavily weathered in the study area and it is likely that most of the clays in the undifferentiated Tertiary-age and Quaternary-age sediments are the residuum of this weathering (Scott, 1988).

\section{Floridan Aquifer System}

The Floridan aquifer system is present throughout Florida and is the primary source of drinking water and spring flow in the region (Miller, 1990). The Floridan aquifer system does not coincide with specific lithostratigraphic units but instead is defined by permeability and hydraulic conductivity (Bush and Johnston, 1988). The Floridan aquifer system is formed in a thick sequence of Tertiary-age carbonate rocks divided into the Upper and Lower Floridan aquifers. In the study area, the two aquifers are hydraulically separated by middle confining unit II (Miller, 1986); because the two systems are separated by a nonleaky gypsiferous and evaporitic carbonate unit with low hydraulic conductivity (Miller, 1986; LaRoche, 2012), the Lower Floridan aquifer is not discussed further. The Floridan aquifer system is artesian throughout much of its range (Miller, 1986), particularly where overlain by the intermediate confining unit; however, Tsala Apopka Lake is situated in an area where the overlying intermediate confining unit is commonly breached by karst activity and is laterally discontinuous, so the Upper Floridan aquifer acts as an unconfined aquifer.

Locally, the Upper Floridan aquifer consists of the upper Avon Park Formation and the Ocala Limestone (figs. 11, 12, and 13). The hydraulic conductivity of the upper Avon Park Formation is typically less than that of the Ocala Limestone due to less karst activity and a more dolomitic composition. Aquifer tests performed by the SWFWMD in the Tsala Apopka Lake area (LaRoche, 2012) indicated that the hydraulic conductivity within the Ocala Limestone was as much as 150 feet per day (ft/d), whereas the upper Avon Park Formation varied from 9 to $28 \mathrm{ft} / \mathrm{d}$. In the study area, the Ocala Limestone is typically the uppermost unit in the Upper Floridan aquifer, though it is possible that isolated remnants of Suwannee Limestone exist. Heavy karstification of the Ocala Limestone creates secondary porosity in the aquifer that greatly increases the hydraulic conductivity of the formation, making it the most productive unit in the Upper Floridan aquifer (Stringfield, 1966).

The common karst activity in the Citrus County area is the result of the discontinuous nature of the intermediate confining unit, generally good hydraulic connection from the surface to the underlying limestone, and close proximity of limestone of the Upper Floridan aquifer to the surface. Without the protection of a clay overburden of the intermediate confining unit, the limestones of the Upper Floridan aquifer are exposed to weathering that actively dissolves the rock (Vernon, 1951; Arthur and others, 2008). The result is numerous sinkholes and internal drainage features typical of karst landscapes. Active karst processes lead to enhanced hydraulic conductivity within the Upper Floridan aquifer as secondary porosity features form. The mean transmissivity value for 
seven aquifer performance tests performed in northern Citrus, Levy, and Marion Counties was 1,070,000 feet squared per day ( $\mathrm{ft}^{2} /$ day; SWFWMD, 2006). Recharge to the Upper Floridan aquifer is directly related to the degree of confinement and the number of karst features present (Copeland and others, 1991). High recharge rates typically occur in areas where there are well-drained sandy soils with a deep-water table, a thin and discontinuous intermediate confining unit, and limestone of the Upper Floridan aquifer that is close to the land surface. Exceptionally high recharge rates occur in areas with these features plus well-developed karst, such as Citrus County. Sepulveda (2002) determined that the highest recharge rates to the Upper Floridan aquifer in the State occur within west-central Citrus County with values ranging from 10 to 25 inches per year (in/yr).

\section{Regional Groundwater Flow}

Potentiometric surface maps of groundwater levels in the Upper Floridan aquifer in September 2007 for the central Florida region (Kinnaman and Dixon, 2008; Ortiz, 2008) were used to infer regional groundwater flow directions (fig. 14). A groundwater divide with a north-south trend exists in central Florida (fig. 14). Tsala Apopka Lake is situated on the western slope of the divide. Regional groundwater flow in central Florida originates from two potentiometric highs - one in Polk County centered near Polk City and one in the northern part of Florida in Alachua and Putnam Counties centered near Keystone Heights. Groundwater in the Polk City high flows northwestward across Lake and Sumter Counties, whereas groundwater in the Keystone Heights high flows south-southwest from north-central Florida. The potentiometric surface of the Upper Floridan aquifer flattens out in central Marion County because of high aquifer transmissivities due to karst activity reflected in the large volume of spring discharge in that area (McBride and others, 2011). Tsala Apopka Lake is within the Northern West-Central Florida Groundwater Basin (SWFWMD, 1987; HydroGeoLogic, 2013) (fig. 14), which is defined at its northeastern end by the Keystone Heights high and its southern end by the Polk City potentiometric high.

\section{Methods}

This study consisted of four data collection and data analysis efforts: determination of discharge through structures, measurement of groundwater levels, water sampling for geochemical analyses, and annual water-budget estimates. Location of wells and surface-water sites used to estimate flow and to sample for geochemical analyses are shown in figure 4 and are listed in table 1. The codes "GW" or "SW" are used to denote groundwater or surface-water sites in this report, and sites are cross-referenced in table 1 with well-site designations as used by other agencies, such as "TA1 UFA" and "ROMP 109 UFA." Details of the equations and methods used to develop rating curves at structures (fig. 2) are described in appendix 1 .

\section{Measurement of Discharge at Structures and Canals}

Discharge was estimated at eight structures in the Tsala Apopka Lake system, including Leslie Heifner, Floral City, Flying Eagle Berm, Golf Course, Moccasin Slough, Brogden Bridge, Brogden Bridge culverts, and Van Ness (fig. 2). Structures are used to manage discharge, fill pools, and maintain target water stages. During 2011 and 2012, discharge was periodically measured at structures by USGS throughout the system to assist in the development of calculated discharge for the 2004-12 water-budget period. There were several years in the study period when no discharge occurred at some of the structures because of low water conditions. Orange State culvert, Bryant Slough, and S-353 remained closed during the study period, so no discharge was measured at these structures. No attempt was made to measure flow at the Consuella Lake or Bradley Lake structures because these are used to maintain stages in these two lakes and not to control flow. Flow data from Shinn Ditch and Flying Eagle Berm culverts were not used in the water-budget calculations. Shinn Ditch is located outside of the water-budget pool area for the Floral City Pool, but a discharge rating was created because it falls within the pool management boundary. Installation of the Flying Eagle Berm culverts was not completed until near the end of the study period. Discharge measurements and real-time streamgage data, when collected, were archived at two sites. Data collected by the SWFWMD are archived in the SWFWMD Water Management Information System (SWFWMD, 2017c) using SWFWMD site identification numbers listed in table 1. Data collected by the USGS are archived in the USGS National Water Information System database (U.S. Geological Survey, 2017a) using USGS station numbers and names as listed in table 1.

Two methods were used to calculate discharge through structures: a rating curve approach and a hydraulic modeling approach. The first involved the development of rating curves using some or all of the following parameters: water stages above and below the structures, gate openings, and streamflow velocities. Discharge rating curves were calibrated using regression analysis and on the basis of hydrodynamic relations as discussed in appendix 1. Hydrodynamic relationships were based on the characteristics of the structure, flow regime, and water stages above and below the structure. The index-velocity method and stage-discharge ratings were used when hydrodynamic relationships could not be developed. Characteristics of structures include the structure elevation, gate dimensions, and number of gates. Flow regime can be defined as orifice or weir flow, depending on the gate opening and headwater stage, and it must be calculated differently for each regime. Each of these flow regimes were further classified as free or submerged, dependent on the tail-water stage, gate opening, 


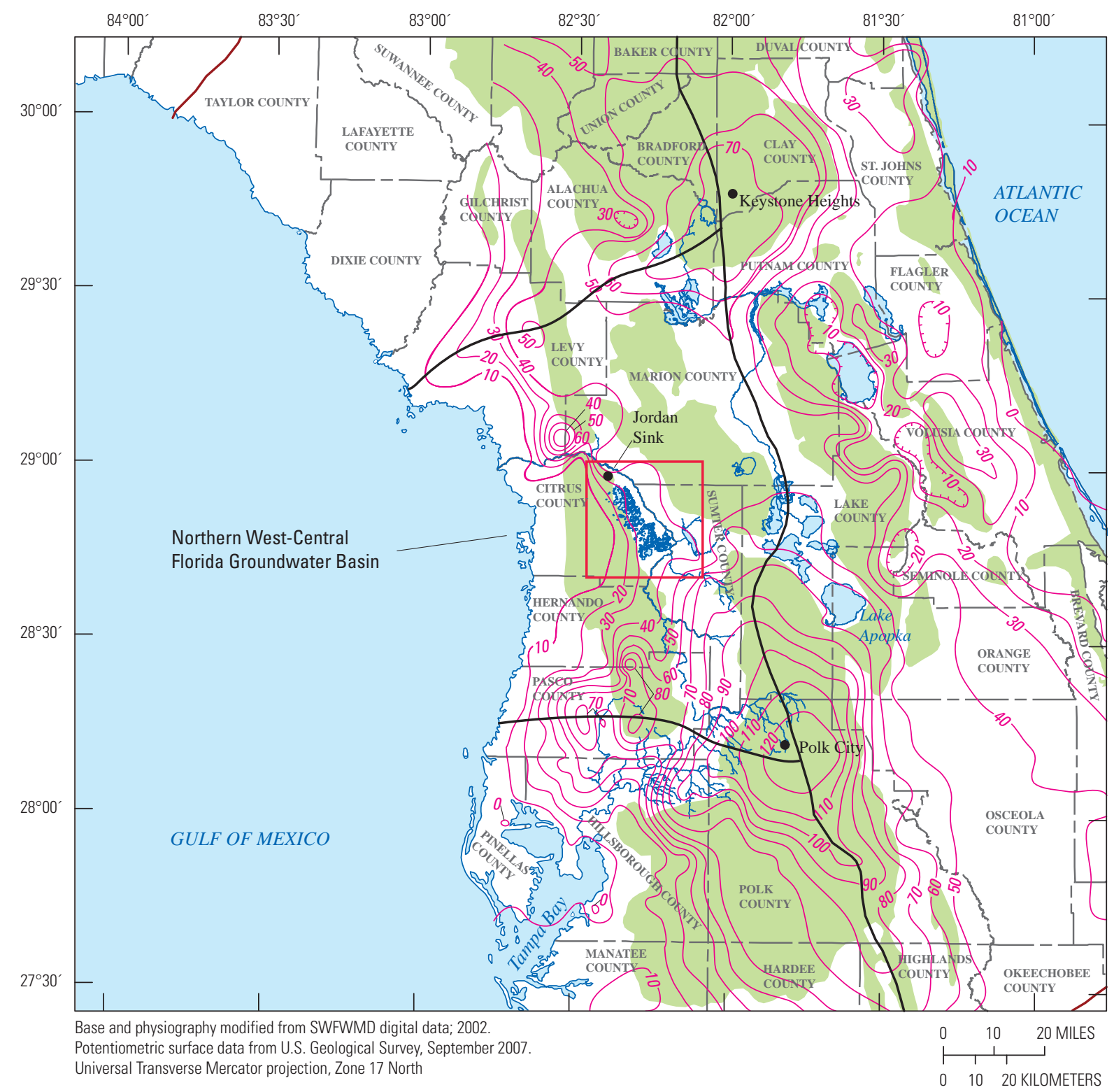

EXPLANATION

Upland and ridge physiographic regions

-60- Potentiometric contour-Shows elevation at which water level would have stood in tightly cased wells. Hachures indicate depression.

Contour interval 10 feet. Datum is National

Geodetic Vertical Datum of 1929

Groundwater divide

General area shown in figure 18

Figure 14. Regional potentiometric surface of the Upper Floridan aquifer, September 2007 (from Kinnaman and Dixon, 2008, and Ortiz, 2008). 
and headwater stage. The criteria that define the characteristics of each regime, and the corresponding flow equations for each structure, are discussed further in appendix 1.

The SWFWMD used a modeling approach to estimate flows through structures for 2004-12 (SWFWMD, 2017a). Discharge measurements and real-time discharge data collected by the USGS, as discussed above, were used to improve the calibration of the SWFWMD models. These models were used for water-budget calculations because long-term flow records were not available. To determine structure flows, stepbackwater calculations (Davidian, 1984; Chow and others, 1988) were performed for each Tsala Apopka Lake structure and the associated canals. The hydraulics of the structures and canals were simulated for the following waterways (fig. 15): (1) Floral City and Leslie Heifner structures and canals between the Withlacoochee River and the Floral City Pool; (2) Golf Course and Moccasin Slough structures and canals between the Floral City Pool and the Inverness Pool; (3) Bryant Slough structure and canal between the Inverness Pool and the Withlacoochee River; (4) Brogden Bridge structure and Brogden Bridge culvert and canals between the Inverness Pool and the Hernando Pool; (5) Van Ness structure and canal between the Hernando Pool and Two Mile Prairie; and (6) the S-353 structure and C-331 canal between the Hernando Pool and the Withlacoochee River.

A number of variables were used in the SWFWMD model surface-water flow calculations: headwater (water stages upstream from the canal), tail water (water stages downstream from the canal), height of gate openings, structure coefficients, channel roughness values, and cross-sectional flow areas. Headwater and tail-water stages were available from USGS and SWFWMD streamgages along the Withlacoochee River and throughout the Tsala Apopka Lake chainof-lakes, and recorded gate openings for each structure were documented by the SWFWMD (2017a).

Cross sections derived from field measured bathymetry of the canal bottom and surveyed structure elevations, all collected by SWFWMD, were used in calculation of crosssectional area of canals. From these data, daily discharge rates were calculated for each structure from 2004 to 2012 and structure coefficients and channel roughness values were adjusted until calculated discharge rates matched measured discharge measurements within 10 percent (SWFWMD, 2017a).

\section{Measurement of Groundwater Levels}

Groundwater levels were measured continuously at a set of 10 paired wells during 2011-14 and measured discretely at 38 wells in May 2012 and October 2012 (fig. 4). Groundwater-level data were used to evaluate the hydraulic connection and groundwater gradients between the surfacewater system, surficial aquifer, and Upper Floridan aquifer. The continuous-recording paired wells, all owned and operated by the SWFWMD, had one well completed in surficial sands and the second in the Upper Floridan aquifer. Completion depths of wells in the surficial aquifer ranged from 6 to $42 \mathrm{ft}$ bls, and completion depths of wells in the Upper Floridan aquifer ranged from 30 to $602 \mathrm{ft}$ bls. Continuous groundwaterlevel data were collected primarily from September 1, 2011, to October 1, 2014, but varied somewhat depending on when the well was constructed. Six of the 10 paired-well sites, designated "TA" for "Tsala Apopka Lake" wells (prefix to short name in table 1), were installed by SWFMWD for this study. A seventh site, designated "Flying Eagle," was completed earlier by the SWFWMD but also with this study in mind. The seven groundwater sites selected specifically for this study were established along transects that extend upgradient and downgradient of the major lakes. The remaining three pairedwell groundwater sites were part of the SWFWMD ROMP well network (SWFWMD, 2017b) and were constructed prior to the study (ROMP 109 SA and UFA, 110 SA and UFA, and 113 SA and UFA).

Potentiometric surface maps were generated using the synoptic groundwater-level measurements made in the Upper Floridan aquifer during the dry season (May and June 2012) and the following wet season (September and October 2012). Precipitation in 2012 was 55.9 in. compared to the long-term mean of 54.0 in. at the Inverness $3 \mathrm{SE}$ weather station (fig. 8). The potentiometric surface is the level to which water rises in a tightly cased well. In a confined aquifer the groundwater level might rise above the top of the aquifer if the aquifer is artesian. In an unconfined aquifer the potentiometric surface is the same as the water table (Fetter, 1994). The slope of the potentiometric surface was used to estimate the gradient and direction of flow of the Upper Floridan aquifer in the study area. The first round of measurements, consisting of one measurement at each well, occurred from May 31 to June 6, 2012, and the second from September 27 to October 4, 2012. Wells labeled with "WL" in table 1 under "Data type" were measured. When the maps were being produced, several data gaps were identified in the coverage and the synoptic water-level data were supplemented with measurements obtained from stations with continuous recorders operated by SWFWMD and USGS. The SWFWMD continuous data came from the Upper Floridan aquifer wells Little Jones Creek UFA (fig. 4, table 1, GW30), Big Jones Creek UFA (GW24), ROMP 121 UFA (GW4), and Gum Springs UFA (GW15), whereas the USGS data came from Rainbow Springs UFA (GW1).

\section{Geochemical Analyses}

Geochemical analyses of water samples were used to determine the types of water (such as calcium type, magnesium type, chloride type, and others), water sources, extent of fractionation and evaporation, and ages of samples. Geochemical sampling sites were selected to represent all of the major hydrologic and hydrogeologic conditions in the study area. Surface-water samples were collected from the major lakes, canals, and streams in the Tsala Apopka Lake pools. 


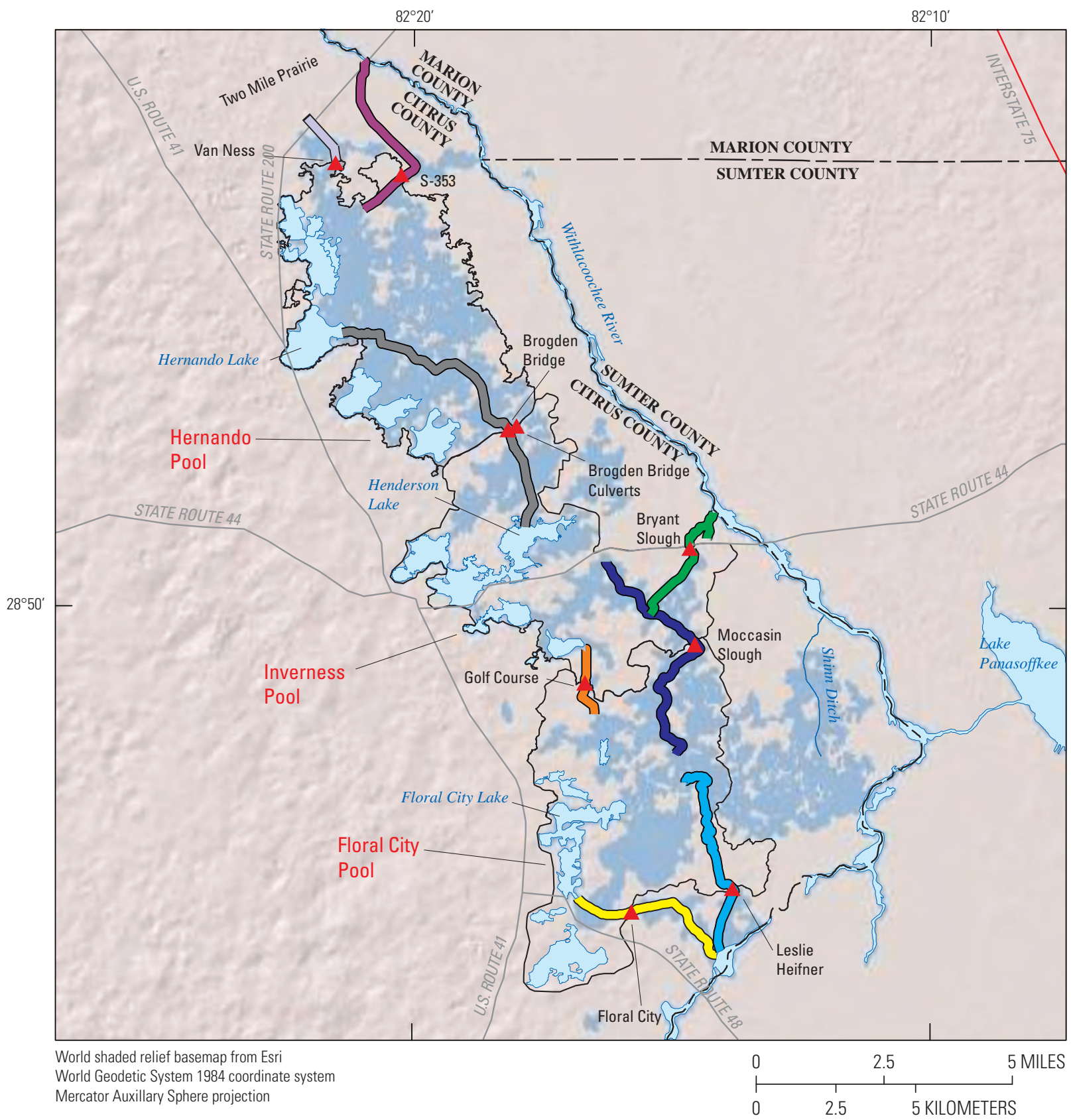

EXPLANATION
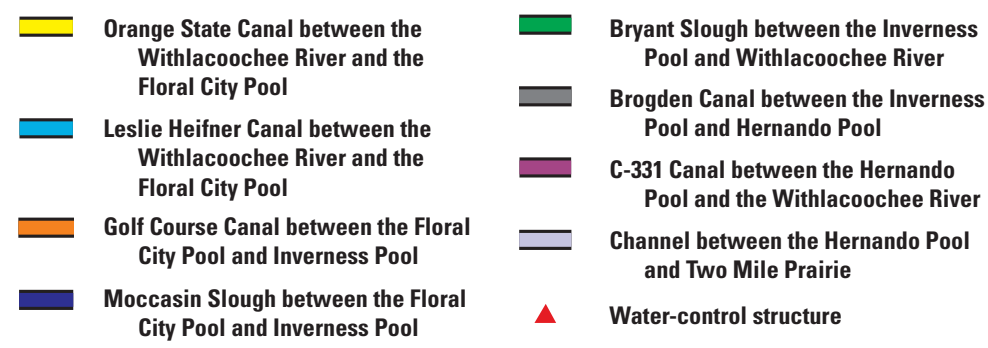

Figure 15. Canals and water-control structures used in the step-backwater calculations for estimating flows in the Tsala Apopka Lake area, 2004-12. 
Groundwater samples were collected from monitoring wells installed in the surficial aquifer and Upper Floridan aquifer. Surface-water and groundwater samples were collected for geochemical analysis once in December 2011 and December 2012. In total, 64 samples at 34 sites were collected during both sampling events, with 32 samples being collected during each sampling event in 2011 and 2012. The same collection sites were used during both sampling events with the following exceptions: samples were collected from the ROMP 116 SA (GW12) and TA2 SA (GW18) wells in 2012 but not in 2011 because the wells were dry in 2011; the TA3 SA well (GW31) was sampled in 2011 and the results were discarded because the sample appeared to be contaminated with bentonite clay, and therefore it was not resampled in 2012; Orange State canal was not resampled in 2012 because of stagnant water at the site; and Gum Slough Spring Run was inaccessible in 2012 because of mechanical issues with a boat. By the time the boat was repaired, hydrologic conditions had changed such that collecting a sample there would not meet the sampling objective of collecting the samples in as short of a time frame as possible.

All water samples were collected using methods described in the USGS "National Field Manual for the Collection of Water-Quality Data" (U.S. Geological Survey, variously dated). Specific conductance, water temperature, $\mathrm{pH}$, dissolved oxygen, turbidity, and alkalinity were measured in the field using calibrated meters. Water samples collected for analysis of major ions, trace elements, organic carbon, and nutrients were filtered in the field through a 0.45 -micrometer capsule filter and analyzed at the USGS National Water Quality Laboratory in Lakewood, Colorado, using inductively coupled plasma atomic emission spectrometry, graphite furnace atomic absorption spectrometry, ion-exchange chromatography, infrared spectrometry, and colorimetry procedures described in Fishman and Friedman (1989), Faires (1993), Fishman (1993), Brenton and Arnett (1993), Garbarino (1999), and Patton and Kryskalla (2003).

The geochemistry of geologic formations in the subsurface, and the amount of time water has been in contact with those formations, largely determines the basic geochemistry of a water sample (Winter and others, 1998). The major ions dissolved in a sample, and the concentration of those ions, make it possible to trace water sources. Major ion data are plotted using both trilinear (Piper) and Stiff diagrams. Trilinear diagrams are used to classify hydrochemical data based on the percentages of major ions in each sample and determine water type. Stiff diagrams are also used to classify the type of water and group similar samples based on the shapes of Stiff polygons of samples. Stiff polygons are wider in shape for water samples with higher ion concentrations. For example, water that has been in contact with the surrounding rocks for a long period of time will be more hydrochemically mature, have a higher concentration of ions, and the associated Stiff polygon will be wider than polygons for less hydrochemically mature waters.
Ratios of ${ }^{87} \mathrm{Sr} /{ }^{86} \mathrm{Sr}$ were determined at the USGS Radiogenic Isotope Laboratory, Menlo Park, California, on a solid source mass spectrometer. Strontium isotopes were analyzed by the positive ion thermal mass spectrometry technique (John Fitzpatrick, USGS, written commun., 2016). For each analysis, a sufficient fluid sample containing approximately 1 microgram of strontium was loaded onto a pre-cleaned cation exchange column, and strontium was separated from other cations and the anions using 2 normal $(\mathrm{N})$ hydrochloric acid as the eluent. The strontium fraction was evaporated to dryness with 40 microliters of $0.5 \mathrm{~N}$ phosphoric acid and converted to a nitrate. The sample was then loaded onto a tantalum ribbon filament and placed in the mass spectrometer. Samples were analyzed for isotopic composition using a double collector dynamic data acquisition approach. Measured ${ }^{87} \mathrm{Sr} /{ }^{86} \mathrm{Sr}$ ratios were corrected for all stable isotope fractionation by simultaneously measuring ${ }^{87} \mathrm{Sr} /{ }^{86} \mathrm{Sr}$, correcting this ratio to a value of 8.37521 , and then correcting the ${ }^{87} \mathrm{Sr} /{ }^{86} \mathrm{Sr}$ ratio using an exponential mass-dependent fractionation relation. The National Institute of Standards and Technology (NIST) strontium carbonate isotopic standard NIST 987, a widely used standard reference material, routinely gives a value of 0.71024 on this instrument. Reported ${ }^{87} \mathrm{Sr} /{ }^{86} \mathrm{Sr}$ ratios are precise to 0.00002 at the 95-percent confidence level.

The isotopes of strontium were used as tracers of flow in the Tsala Apopka Lake study area. Strontium isotopes are useful for determining groundwater sources because each hydrogeologic unit has a unique ${ }^{87} \mathrm{Sr} /{ }^{86} \mathrm{Sr}$ ratio that corresponds to the isotopic ratio of the seawater in which the unit formed. Water can be traced to its source by comparing the ${ }^{87} \mathrm{Sr} /{ }^{86} \mathrm{Sr}$ ratio of the strontium dissolved in the groundwater with the known ${ }^{87} \mathrm{Sr} /{ }^{86} \mathrm{Sr}$ ratio of each stratigraphic unit (DePaolo and Ingram, 1985; Katz and Bullen, 1996). The ${ }^{87} \mathrm{Sr} /{ }^{86} \mathrm{Sr}$ ratios from surface-water samples were compared to ratios from groundwater samples to determine whether the surface-water bodies receive groundwater inflow.

The ratios of oxygen-18 and oxygen- $16\left({ }^{18} \mathrm{O} /{ }^{16} \mathrm{O}\right)$ isotopes and deuterium and hydrogen $\left({ }^{2} \mathrm{H} / \mathrm{H}\right.$ or $\left.\mathrm{D} / \mathrm{H}\right)$ isotopes were determined at the USGS Reston Stable Isotope Laboratory in Reston, Virginia, using the isotope ratio-mass spectrometer by hydrogen gas water equilibration and carbon dioxide water equilibration techniques and reported relative to Vienna Standard Mean Ocean Water (Epstein and Mayeda, 1953; Coplen and others, 1991; Coplen, 1994). Stable isotopes are usually reported using delta $(\delta)$ notation because laboratories measure the relative differences in isotopic ratios rather than the absolute ratios. Delta values are reported in per mil (\%o), or parts per thousand. For example, the delta value for oxygen isotopic ratios is denoted as $\delta^{18} \mathrm{O}$, and delta value for hydrogen isotopic rations is denoted as $\delta \mathrm{D}$. The delta value $\left(\delta_{\text {sample }}\right)$ is computed using the following equation (McKinney and others, 1950):

$$
\left.\delta_{\text {sample }}=1,000\left[\left(R_{\text {sample }} / R_{\text {ref }}\right)-1\right)\right]
$$

where $R_{\text {sample }}$ and $R_{\text {ref }}$ are the isotopic ratios of the sample and reference, respectively. 
Stable isotopes of oxygen and hydrogen are useful for determining water sources and for evaluating the mixing of groundwater and surface-water sources (Gonfiantini, 1986; Katz and others, 1997). Worldwide, meteoric water (rainwater) has a consistent $\delta \mathrm{D}$ and $\delta^{18} \mathrm{O}$ relationship known as the "global meteoric water line" (GMWL), which is defined using the following equation (Craig, 1961):

$$
\delta \mathrm{D}=8 \delta^{18} \mathrm{O}+10
$$

Sacks (2002) developed a local meteoric water line (LMWL) for west-central Florida by collecting and compositing monthly rainfall samples and then analyzing the samples for $\delta \mathrm{D}$ and $\delta^{18} \mathrm{O}$. The LMWL was defined using the following equation:

$$
\delta \mathrm{D}=7.73 \delta^{18} \mathrm{O}+11.62
$$

The LMWL more accurately represents the ambient variability of $\delta \mathrm{D}$ and $\delta^{18} \mathrm{O}$ in rainfall in west-central Florida than the GMWL.

Once meteoric water has been deposited on the land surface, kinetic processes, such as evaporation and condensation, cause the stable isotopes of water to fractionate and become enriched in the heavier isotope. Water that recharges quickly to the groundwater system maintains an isotopic signature similar to the meteoric source, but the longer water remains at the land surface the more enriched the $\delta \mathrm{D}$ and $\delta^{18} \mathrm{O}$ signature becomes. Water affected by evaporation is offset to the right of the meteoric water lines when $\delta \mathrm{D}$ is graphically plotted against $\delta^{18} \mathrm{O}$ because of differences in how the two isotopes fractionate during evaporation (Sacks, 2002). The evaporation trend line provides useful information regarding sources of water in a watershed and is computed as a best-fit line through the isotopic data associated with field samples. Waters having undergone the most evaporation, typically because of longer residence times at land surface, plot farthest to the right, which will decrease the slope of the evaporation trend line. Once water recharges to the groundwater system, it typically maintains the same isotopic signature it attained at the land surface, which makes it possible to determine sources of recharge.

Sulfur hexafluoride $\left(\mathrm{SF}_{6}\right)$ and dissolved gas analysis of groundwater samples were analyzed by the USGS Reston Groundwater Dating Laboratory in Reston, Va. The $\mathrm{SF}_{6}$ was analyzed using procedures described by Busenberg and others (1998) and Busenberg and Plummer (2000). The $\mathrm{SF}_{6}$ is a trace atmospheric gas, primarily anthropogenic in origin, which is useful for dating young groundwater that has recharged in the last 40 years or so (Busenberg and Plummer, 2000). The atmospheric concentration of $\mathrm{SF}_{6}$ has risen steadily in Earth's atmosphere, about 7 percent per year, since the 1950s when its use in industrial processes increased. It is possible to date groundwater using $\mathrm{SF}_{6}$ because water vapor in the atmosphere comes to equilibrium with the atmospheric concentration of $\mathrm{SF}_{6}$ before falling back to earth as precipitation. $\mathrm{The} \mathrm{SF}_{6}$ is stable and non-reactive, so groundwater maintains the atmospheric concentration of $\mathrm{SF}_{6}$ even after recharge. The date of groundwater recharge can be determined by comparing the concentration of $\mathrm{SF}_{6}$ measured in groundwater with air curves displaying the concentration of $\mathrm{SF}_{6}$ in the atmosphere during the last 40 years (Busenberg and Plummer, 2000).

Dissolved gases (nitrogen, argon, carbon dioxide, and methane) were measured in groundwater samples by gas chromatography after extraction in headspaces of glass samplers (Busenberg and others, 1998; Busenberg and Plummer, 2000). Dissolved gases are useful for determining the temperature at which groundwater recharged. For young groundwater, recharge temperature can provide information regarding the seasonality of recharge events and, for old water, it can provide information regarding the paleoclimate under which recharge occurred.

Groundwater samples were analyzed for the concentration of tritium $\left({ }^{3} \mathrm{H}\right)$ by Lamont-Doherty Earth Observatory in Palisades, New York, using quantitative gas extraction followed by mass spectrometric techniques (Ludin and others, 1998). The ${ }^{3} \mathrm{H}$ data were not used directly to compute apparent recharge age but were used to verify the recharge ages established using $\mathrm{SF}_{6}$ data. Tritium naturally occurs in the atmosphere at low levels, but above-ground hydrogen bomb testing in the 1950s caused large increases until the practice was banned in 1963. Since that time, the atmospheric concentration has decreased exponentially and has nearly returned to pre-bomb levels (Clark and Fritz, 1997). The ${ }^{3} \mathrm{H}$ data alone cannot be used to date groundwater in the way that $\mathrm{SF}_{6}$ data can because the concentration is constantly changing because of radioactive decay $-{ }^{3} \mathrm{H}$ has a half-life of 12.43 years. The $\mathrm{SF}_{6}$ data were validated by back-calculating the ${ }^{3} \mathrm{H}$ concentration in the samples to the level that would have been present on the recharge year determined by the $\mathrm{SF}_{6}$ method, on the basis of the decay rate of ${ }^{3} \mathrm{H}$ applied during that time period (McBride and Wacker, 2015; Stamm and McBride, 2016). If the back-calculated ${ }^{3} \mathrm{H}$ concentration approximates the known atmospheric concentration for the recharge year determined by the $\mathrm{SF}_{6}$ method, then the $\mathrm{SF}_{6}$ method is considered valid. The apparent age is estimated as the year in which observed tritium concentrations in north Florida equaled the back-calculated concentration (Stamm and McBride, 2016). Water samples that contained no measureable tritium have been isolated from the atmosphere since before bomb testing commenced, so the data are also useful for determining whether samples contain only water recharged prior to atomic bomb testing (Clark and Fritz, 1997).

\section{Water-Budget Computations}

The general water-budget equation used for each pool and for the combined three-pool area is as follows:

$$
\Delta S=\mathrm{P}-\mathrm{E}+S W_{\mathrm{i}}-S W_{\mathrm{o}}+\mathrm{G}_{\mathrm{i}}-\mathrm{G}_{\mathrm{o}}
$$


where

$\begin{array}{cl}\Delta S & \text { is the combined change in surface and } \\ \text { groundwater storage, } \\ \mathrm{P} & \text { is precipitation, } \\ \mathrm{E} & \text { is evapotranspiration, } \\ S W_{\mathrm{i}} & \text { is surface-water inflow from the canals, } \\ S W_{0} & \text { is surface-water outflow from the canals, } \\ \mathrm{G}_{\mathrm{i}} & \text { is groundwater inflow, and } \\ \mathrm{G}_{0} & \text { is groundwater outflow or downward leakage. }\end{array}$

For this analysis, all of the water-budget components were computed in inches per year over the surface area associated with the control volume, so that water-budget terms could easily be compared between pools that have dissimilar surface areas. Linear units were computed by dividing the change in lake volumes and volumetric fluxes by the pool surface area. The conceptual diagram of the water budget is shown in figure 3. Surface-water inflow and outflow measurements used in the budget calculations are discussed in the "Measurement of Discharge at Structures and Canals" section and appendix 1.

An approach to water-budget calculation is to consider the lake as the control volume; however, the Tsala Apopka Lake system is complex, with emergent areas between lakes that potentially generate surface runoff. Surface topography and long-term lake-stage data were used to determine the historical extent of the lake and adjoining wetlands and incorporate emergent area within the three pools. The pool boundary was delineated as the extent of flooded area at the maximum stage of the lake in 2004-12 plus $0.5 \mathrm{ft}$ additional land elevation. It was assumed that above the elevation of the boundary, precipitation would infiltrate and not produce overland flow to the pool and infiltrated water would not flow laterally to the pool. The pool boundaries used in this water-budget analysis (figs. 1 and 2) coincide with the contour of the surface elevation of $42.5 \mathrm{ft}$ for Floral City Pool, $41.0 \mathrm{ft}$ for the Inverness Pool, and $39.5 \mathrm{ft}$ for the Hernando Pool. It is possible that the no-flow boundary used for this study could be exceeded under extreme hydrologic conditions. Using these methods applied to a digital elevation model (DEM) of bathymetry and topography, the surface areas associated with the control volumes for the Floral City Pool, Inverness Pool, and Hernando Pool were determined to be 12,$495 ; 10,774$; and 11,257 acres, respectively. Sources of bathymetric and topographic data are discussed later in this section.

Stage-volume curves were developed for each pool to determine the change in volume (change in storage) for the lakes and wetlands for a particular change in stage (fig. 16). For this analysis, stage in lakes and adjoining wetlands in each pool were considered to be at the same elevation because the lakes and surrounding wetlands were typically contiguous; however, during extremely dry periods, the lakes and wetlands became disconnected and therefore stages differed slightly. No data were available to correct for the differing stages. The stage-volume curves were developed using mean daily lake stage measured to within $0.01 \mathrm{ft}$ from Floral City Lake (figs. 1 and 4, table 1, SW18, Floral City Pool), Henderson Lake

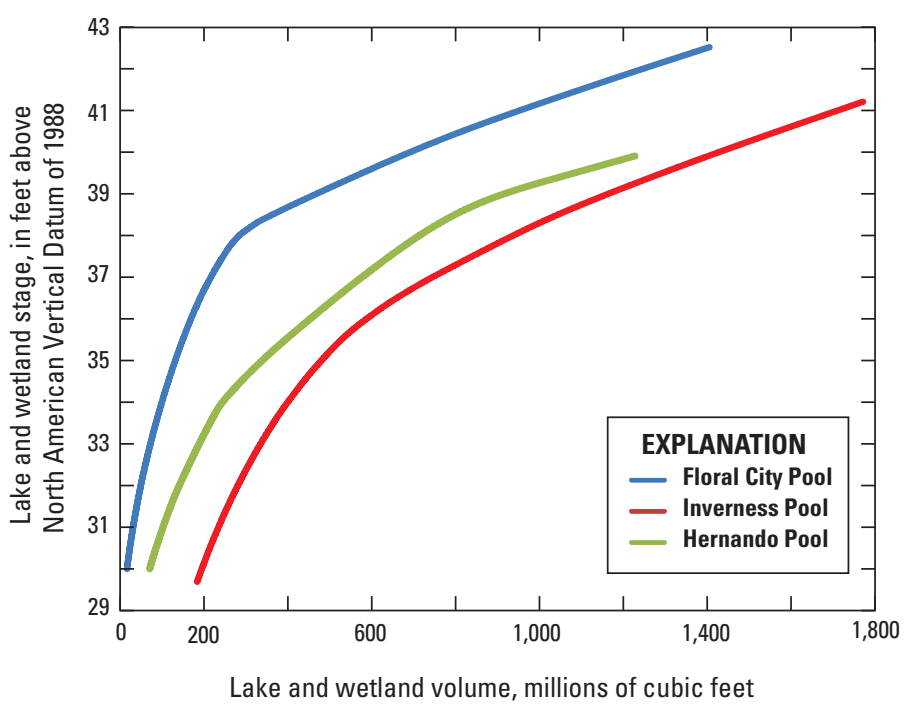

Figure 16. Stage-volume relation curves for lakes and connecting wetlands in the Floral City Pool, Inverness Pool, and Hernando Pool (Southwest Florida Water Management District, 2017c).

(SW10, Inverness Pool), and Hernando Lake (SW6, Hernando Pool) for January 1, 2004, to December 31, 2012. Stage data for the lake stations listed above are available from SWFWMD (2017c). Error of the change in lake stage was assumed to be 10 percent (Swancar and others, 2000) for the daily values used to compute annual water budgets. Annual error would be much less than daily error. A volumetric surface model was developed using the DEM (derived from light detection and ranging [lidar]), previously described, that incorporated the lake bathymetry, wetland, river, and canal elevations. For each $0.01 \mathrm{ft}$ increment of elevation change, surface area (square feet) and volume (cubic feet) were calculated. A lake volume to lake stage relationship was developed on the basis of an incremental increase in stage applied over the pool area using the DEM (generated from lidar and bathymetry data) for each pool. The DEM elevations that were less than the given lakestage elevation were considered flooded and part of the lake area for the pool, including detached areas that may not have been directly connected to a major lake, such as isolated ponds and wetlands.

The water-table fluctuation method (Healy and Cook, 2002) was used to determine the daily change in groundwater storage in each pool. The water-table fluctuation method assumes that a water-table rise in an unconfined aquifer was attributable to positive change in groundwater storage or recharge, and a negative change is attributable to leakage to the underlying aquifer or evapotranspiration. Change in groundwater storage $(\Delta S)$ is calculated using the following equation: 


$$
\Delta S=S_{\mathrm{y}} \Delta \mathrm{h} / \Delta \mathrm{t}
$$

where
$S_{y} \quad$ is the specific yield, and
$\Delta \mathrm{h} / \Delta \mathrm{t} \quad$ is the change in water-table height over a given time.

Reported specific yield for the surficial aquifer ranges from 0.00005 to 0.3 (SWFWMD, 2006) and Freeze and Cherry (1979) indicate a typical range for unconfined aquifers is 0.01 to 0.3 . In the study area, the surficial aquifer is generally described in well logs as sands and clays. Johnson (1967) indicates that unconsolidated clay and sand has a specific yield as high as approximately 0.10 ; therefore, specific yield was assumed herein to be a constant value of 0.10 for the surficial aquifer.

Water-table fluctuations were determined for the threepool area using groundwater-level data collected at the ROMP 110 SA well (fig. 4, table 1, GW51) for 2004-12. Using data from a single well to predict changes in groundwater storage over the three-pool area was not ideal and is one of largest sources of error in the water budget. Preferably, groundwaterlevel data would have been available for at least one surficial aquifer well in each pool, but there were no wells in the Inverness or Hernando Pools with continuous records that covered the 2004-12 water budget period. Nearby Tsala Apopka Lake surficial aquifer wells, such as TA1 SA through TA6 SA and Flying Eagle SA (fig. 4, table 1, GW21, GW18, GW31, GW43, GW49, GW38, and GW35, respectively), were installed during 2010-12, so the period of record was not sufficient for the water-budget analysis. To determine whether the ROMP 110 SA groundwater-level data reasonably represented the groundwater conditions in the three-pool area, correlations were calculated comparing monthly mean groundwater levels of the surficial aquifer at ROMP 110 SA with the TA1-6 SA and Flying Eagle SA wells from October 2011 to September 2014. The correlations ranged from 0.71 to 0.95 , indicating that the ROMP 110 SA well data reasonably approximated the conditions of the surficial aquifer. Data from the TA5 SA well were not included in the calculations because the well was dry for much of the period. Ideally, groundwater storage estimates would include statistical confidence intervals, but calculation of formal error estimates is not practical because of the wide range of inaccuracies in spatial and temporal variability, measurement errors, and the validity of assumptions upon which different methods are based (Healy and Cook, 2002). Based only on the correlation calculations, the maximum annual error in the change of groundwater storage was assumed to be 30 percent.

Groundwater volume was calculated for the area in each pool that was not part of the dynamic surface-water area. As the inundated area increased, such as during the wet season, the area of the surficial aquifer decreased because the pool area is fixed. Groundwater storage volume was calculated as the change in storage (eq. 5) multiplied by the area of the pool not inundated by lakes. Analysis of elevations and thicknesses of surficial aquifer deposits at Upper Floridan aquifer wells TA5 UFA (fig. 4, table 1, GW48) in the Floral City Pool, TA3 UFA (GW32) in the Inverness Pool, and TA1 UFA (GW22) in the Hernando Pool indicated that the base of the surficial aquifer deposits is about the same, or less, than the elevation of the deepest section of the closest major lakes. The elevation of the base of the undifferentiated deposits at the TA5 UFA, TA3 UFA, and TA1 UFA sites was approximately 27,11 , and $23 \mathrm{ft}$, respectively, whereas the elevation of the deepest points in Floral City Lake, Henderson Lake, and Hernando Lake were $26-27 \mathrm{ft}, 22-23 \mathrm{ft}$, and $17-20 \mathrm{ft}$, respectively.

Annual rainfall data used for the water-budget analysis were derived from two sources: Next-Generation Radar (NEXRAD) data, and measured rainfall from weather stations operated by the SWFWMD and NOAA. The NEXRAD data were spatially distributed to a 2-kilometer $\times 2$-kilometer $(1.24-\mathrm{mi} \times 1.24-\mathrm{mi})$ cell grid and were considered to be more accurate than estimating precipitation based on weather station data because of the increased spatial resolution of the NEXRAD datasets compared to data collected at widely spaced weather stations (Hoblit and others, 2003). The NEXRAD data and grid extent are available online from SWFWMD (2017d). The NEXRAD grid cells within each pool were selected on the basis of the criteria that the centroid of the NEXRAD grid cell was within the pool area (fig. 17).

Rainfall data from five SWFWMD weather stations and one NOAA station, shown on figure 4 , were used to validate the NEXRAD rainfall data. In the Floral City Pool, discrepancy in annual rainfall ranged from 5 percent in 2004 to 12 percent in 2007 when NEXRAD data were compared to the SWFWMD 22907 and 22911 weather stations, with a mean discrepancy of 5 percent from 2004 to 2012. In the Inverness Pool, discrepancy in annual rainfall ranged from -6 percent in 2004 to 3 percent in 2007, with a mean discrepancy of 2 percent for the 9-year period, using rainfall data from the SWFWMD 23484 and NOAA Inverness 3 SE stations. In the Hernando Pool, comparisons were made using data from the SWFWMD 23597 and 23611 stations, but the 23611 data were discarded because of extensive missing data. Using data only from the 23597 station, discrepancy in annual rainfall ranged from -30 percent in 2008 and 2011 to 6 percent in 2004, with a mean of -15 percent for the 9 -year period. Because of the unusually high discrepancy in the comparison, the Hernando Pool NEXRAD data were also compared to data from the SWFWMD 23484 weather station located in the Inverness Pool, which is the next closest weather station. The percent discrepancy in annual rainfall using the SWFWMD 23484 data ranged from -23 percent in 2007 to 13 percent in 2011, with a mean of -8 percent from 2004 to 2012 . The combined data from SWFWMD 23597 and 23484 ranged from -23 percent discrepancy in 2008 to 1 percent discrepancy in 2004, with a mean of 12 percent. The mean annual discrepancy for the composite three-pool area was 6 percent. Based on a paired sample t-test for means, annual rainfall for all pairs of rain gages and NEXRAD pixels was not significantly different at the 0.05 probability of a type-I error (probability of 


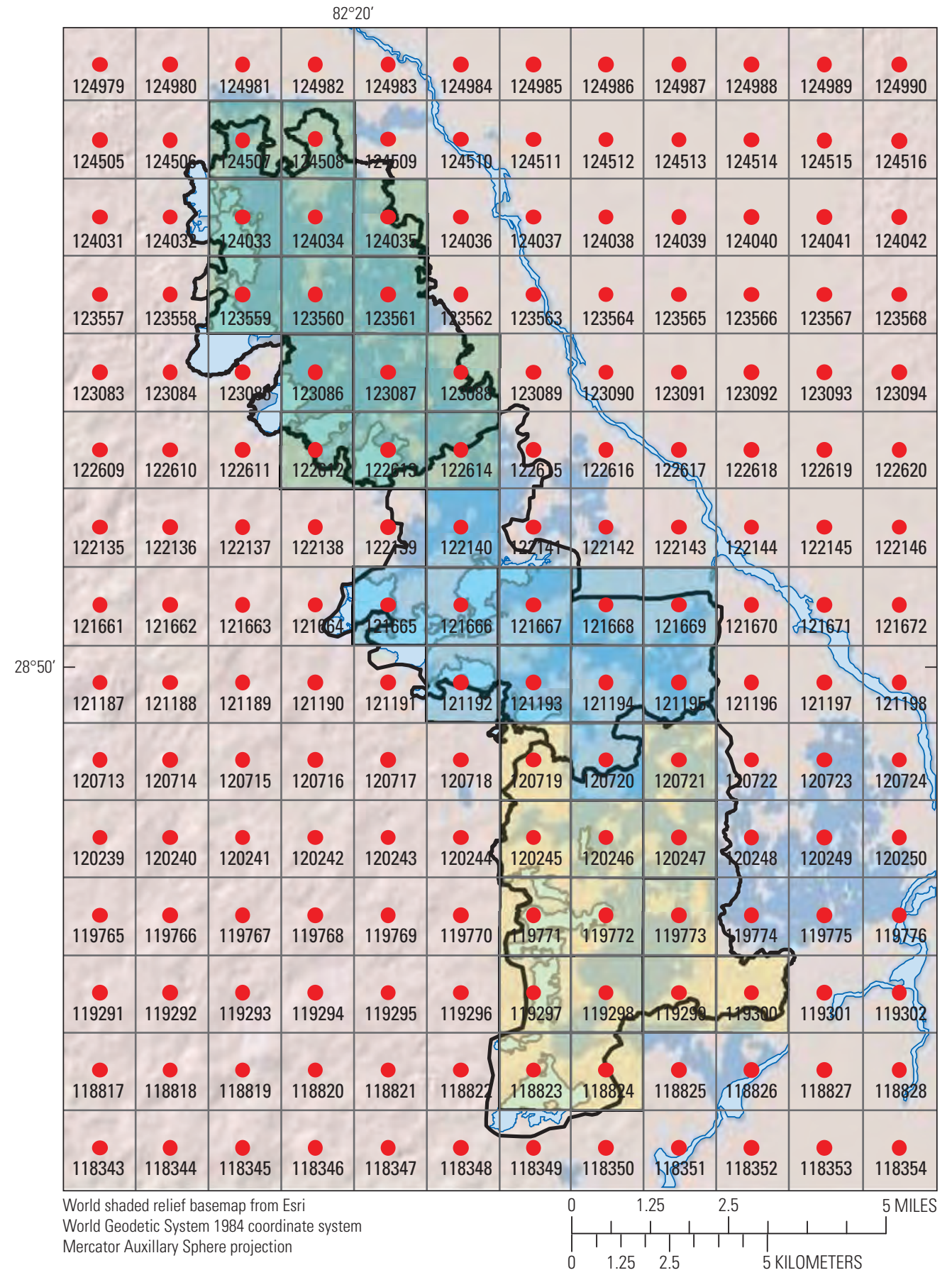

EXPLANATION

Centroid of cell

Cells used in the Floral City Pool analysis

Cells used in the Inverness Pool analysis

Cells used in the Hernando Pool analysis

Figure 17. Two-kilometer Next-Generation Radar (NEXRAD) grid cells used in the calculation of rainfall and evapotranspiration in the Floral City Pool, Inverness Pool, Hernando Pool, and the composite three-pool area. 
rejecting difference when difference exists). Discrepancies in the amount of rainfall recorded at each gage are the result of real differences in rainfall at each site combined with measurement error inherent with each rain gage.

Land-surface elevations in the three pools were determined using lidar data collected in 2006 under contract by the SWFWMD (NOAA, 2017a). The lidar data, 1-meter postings with a vertical accuracy of plus or minus 9.25 centimeters, were processed into a hydro-enforced and hydro-flattened DEM with a 5 -ft grid spacing. Bathymetric survey and field measured elevation data, collected by SWFWMD between 2007 and 2012 for the lakes, wetlands, and canals throughout Tsala Apopka Lake, were incorporated into the DEM by SWFMWD to better represent land-surface elevations in inundated areas that could not be determined using lidar. The processed DEM is available from SWFWMD upon request because the large size of the file prevents the model from being permanently available online.

Land cover in the three pools was determined using data aggregated by SWFWMD (2017e) for 2011. Land cover was generalized into six basic types: forest, grass, wetland, lake, ridge, and urban. Land-cover types were mapped to a 500 -meter $\times 500$-meter grid resolution. Based on the land-use grid, the distribution of the six land-cover types within each 2-kilometer $\times 2$-kilometer NEXRAD grid cell was computed.

A gridded product of reference evapotranspiration (RET) across Florida is available online from the USGS (2017b). The RET is evapotranspiration from a well-watered grass surface, computed using methods described by Mecikalski and others (2011). The grid dimensions and projection of the RET product are equivalent to that of the NEXRAD grid. Actual evapotranspiration (AET) was computed as a function of RET at a grid cell multiplied by annually invariant, monthly landcover coefficients (Sumner, 2006). Land-cover coefficients were computed as the ratio of observed AET to RET for each land-cover type and month, weighted as a function of the distribution of land-cover types within a grid cell. The ratio of AET to RET was computed on the basis of observations at several evapotranspiration stations in Florida that represented the six land-cover types: forest, grass, wetland, lake, ridge, and urban. Stations representing land-cover types include (fig. 1) Tiger Bay for forest (Sumner, 2017a), Lake Wales Ridge for ridge (Sumner, 2017b), and Orlando for urban (Sumner and others, 2017). Stations representing other land-cover types (U.S. Geological Survey, 2017b) include Duda Farms (USGS station number 281626080463400) for grass, Blue Cypress (USGS station number 274143080424100) for wetland, and Reedy Lake (USGS station number 282458081364800) for lake. Once AET was computed as a function of RET and land-cover coefficients, the AET for all grid cells in a pool was integrated to estimate the AET for the pool area. Daily AET for each pool was computed for 2004-12. The assumed error of the daily AET values used to compute annual AET is 10 percent.
To determine net groundwater flow $\left(\mathrm{G}_{\text {net }}\right.$, groundwater inflow minus groundwater outflow), the water-budget equation (eq. 4) was rearranged as follows:

$$
\mathrm{G}_{\text {net }}=\mathrm{G}_{\mathrm{i}}-\mathrm{G}_{0}=\Delta S-\mathrm{P}+\mathrm{E}-S W_{\mathrm{i}}+S W_{0} \text {, }
$$

where $G_{\text {net }}$ is positive when groundwater inflow exceeds groundwater outflow. Likewise, $G_{\text {net }}$ is negative when groundwater outflow (downward and lateral leakage) exceeds groundwater inflow.

Although the water-budget approach provides the means for determining the hydrologic conditions of each pool, there are inherent uncertainties in the water-budget calculations and quantifying these uncertainties is extremely important to the interpretation of the final water budget (Winter, 1981). Some of these uncertainties include determining the storage of the wetlands using connecting lake stages, change in groundwater storage using limited available well data, indirect measurements of rainfall and evapotranspiration, the accuracy of calculated surface-water flows (affected by vegetation and debris), and the magnitude of overland flow from outside the pool area and its contribution to the water budget (assumed to be zero). Although the best available data were used for the water-budget calculations, these data should only be used to make generalized comparisons and to aid in our understanding of the surface-water/groundwater conditions in each of the three pools and in the composite three-pool area.

Net groundwater flow results provide an insight into surface-water/groundwater exchange and the effect that surface-water inflow has on the groundwater system in the three pools. This analysis focused on the annual $G_{\text {net }}$ instead of monthly rates because of the lower uncertainty of the former. When the uncertainty error $\left(\mathrm{e}_{\mathrm{Gnet}}\right)$ was greater than or equal to $G_{\text {net }}$ rate, especially when the amount of $G_{\text {net }}$ was small, a definitive amount of $G_{\text {net }}$ could not be determined.

Because $G_{\text {net }}$ is computed as a residual term, the $G_{\text {net }}$ term incorporates all of the uncertainties in the other water-budget terms. Uncertainties can come from measurement error, extrapolation of point data to regional areas, and ambiguities in computed or assumed parameters used to calculate terms (Winter, 1981). The assumed uncertainties in annual waterbudget terms included surface-water and groundwater storage (30 percent), NEXRAD rainfall (6 percent), AET (10 percent), and surface-water inflow and outflow calculation (10 percent). Explanations of how the uncertainty of each parameter was derived can be found in the respective sections above.

Assuming that the errors in the other water-budget terms are independent, the uncertainty in $G_{\text {net }}$ (or the standard deviation around $G_{\text {net }}$ ) is the square root of the sum of the squared individual uncertainties of annual values (Winter, 1981):

$$
e_{G_{\text {net }}}=\sqrt{e_{\Delta S}^{2}+e_{P}^{2}+e_{E}^{2}+e_{S W_{i}^{2}}^{2}+e_{S W_{o}}^{2}},
$$


where

$\begin{array}{cl}e_{G \text { net }} & \text { is the uncertainty (standard deviation) in net } \\ & \text { groundwater flow, } \\ e_{\Delta S} & \text { is error in change in storage, } \\ e_{P} & \text { is error in precipitation, } \\ e_{E} & \text { is error in evapotranspiration, } \\ e_{S W i} & \text { is error in surface-water inflow, and } \\ e_{S W o} & \text { is error in surface-water outflow. }\end{array}$

When $G_{\text {net }}$ is small, the cumulative uncertainty in the other water-budget terms can exceed the computed $G_{\text {net }}$.

\section{Groundwater Levels}

Groundwater levels for the Upper Floridan aquifer were analyzed by constructing potentiometric surface maps (fig. 18) for May and June 2012 (dry season) and September and October 2012 (wet season). Annual precipitation for 2012 was $55.9 \mathrm{in}$., which slightly exceeded the mean annual precipitation for 1930-2014 of 54.0 in. (fig. 8). Potentiometric surface maps for the two seasons were similar, except the hydraulic gradient was slightly steeper during the wet season. Groundwater in the Upper Floridan aquifer generally flows west-southwest in the study area. East of the Withlacoochee River, such as near Lake Panasoffkee, the hydraulic gradient in the Upper Floridan aquifer is low. In the vicinity of Tsala Apopka Lake the gradient steepens, but to the west, from the Brooksville Ridge to the Gulf coast, the potentiometric surface is nearly flat. The changes in hydraulic gradient correspond with changes in the transmissivity of the Upper Floridan aquifer. East of Tsala Apopka Lake and the Withlacoochee River, the Ocala Limestone becomes thin in the vicinity of Lake Panasoffkee (figs. 12 and 13), which reduces the transmissivity of the Upper Floridan aquifer because the underlying Avon Park Formation lacks the hydraulic conductivity of the Ocala Limestone (McBride and others, 2011; Williams and others, 2011). The decrease in transmissivity, in conjunction with the upward slope of the Avon Park Formation from east to west (fig. 13), results in groundwater discharge conditions east of the Withlacoochee River, especially near Lake Panasoffkee (McBride and others, 2011). In the vicinity of Tsala Apopka Lake, the Ocala Limestone begins to slope downward from east to west and becomes thicker in the same direction. As the Upper Floridan aquifer becomes more deeply buried the sediments of the surficial aquifer become correspondingly thicker and the water table is farther from the land surface.

Wells within the study area had depths to groundwater (fig. 18) that ranged from 4 to $132 \mathrm{ft}$ bls in May and June 2012 (dry season) and 1 to $138 \mathrm{ft}$ bls in September and October 2012 (wet season). Water levels were nearest the surface at wells along a reach of the Withlacoochee River downstream from Lake Panasoffkee and upstream from Rutland. Groundwater could be discharging to the Withlacoochee River along this reach; however, the reach is downstream from the diversion point of streamflow from the Withlacoochee River to Tsala Apopka Lake at the Orange State and Leslie Heifner canals (fig. 2). Wells where groundwater was farthest from the surface were in the area of the Brooksville Ridge, west of the Tsala Apopka Lakes, where land-surface elevations were highest.

Continuous groundwater-level data were used to evaluate the hydraulic relationships of the surficial aquifer, Upper Floridan aquifer, and major Tsala Apopka lakes. West of the Withlacoochee River and east of the major lakes, data were collected from paired surficial aquifer and Upper Floridan aquifer wells at the TA2 SA and UFA, Flying Eagle SA and UFA, TA6 SA and UFA, TA4 SA and UFA, and ROMP 110 SA and UFA sites (figs. 4 and 19, table 1, GW18, GW35, GW38, GW43, and GW51; only the site code for the surficial aquifer well will be listed when discussing paired wells) indicated that the hydraulic head in the two aquifers was nearly equal most of the time. The surficial aquifer and Upper Floridan aquifer for the TA2 SA and UFA, TA4 SA and UFA, Flying Eagle SA and UFA, and ROMP 110 SA and UFA wells generally acted as a single hydrogeologic unit. After heavy rainfall the groundwater level rose rapidly in both aquifers with almost no lag. Well drilling logs (Dawson, 2007; Horstman, 2011) indicate that a 4-22-ft thick clay confining unit is present at these sites at the base of the surficial aquifer, but the lack of a vertical head gradient, and the simultaneous reaction of both aquifers to rainfall, indicates that the confining unit is ineffective, likely because it is either breached by numerous buried karst features or is laterally discontinuous. The hydraulic head for the Upper Floridan aquifer was higher than that for the surficial aquifer during dry periods at the TA6 SA and UFA wells, indicating the confining unit might be more effective at this site when water levels are relatively low, during which time the Upper Floridan aquifer has the potential to recharge the surficial aquifer. Otherwise, the lack of a vertical hydraulic gradient between the surficial aquifer and Upper Floridan aquifer (neither upward nor downward) indicates that recharge potential from the bottom of the surficial aquifer to the Upper Floridan aquifer is low in this area.

Near the western shoreline of the major Tsala Apopka lakes, and east of the Brooksville Ridge, there was a difference in head of the surficial aquifer and Upper Floridan aquifer of approximately $2-18 \mathrm{ft}$ from the surficial aquifer to the Upper Floridan aquifer (fig. 20). Groundwater-level data collected at sites TA5 SA and UFA, TA3 UFA, and TA1 (figs. 4 and 20, table 1, GW49, GW31, and GW21) were consistently higher in the surficial aquifer than the Upper Floridan aquifer, which indicates that the surficial aquifer has the potential to recharge the Upper Floridan aquifer if there is a hydraulic connection between the two aquifers. Drilling records (Dawson, 2004; Horstman, 2011) indicate the presence of a confining unit from 3 to $34 \mathrm{ft}$ thick in this area, as well (fig. 4, table 1, GW12, GW21, GW31, and GW49). Similar to groundwater levels at wells in the eastern part of the study area, groundwater levels fluctuated in the two aquifers nearly simultaneously in 
A. May and June 2012

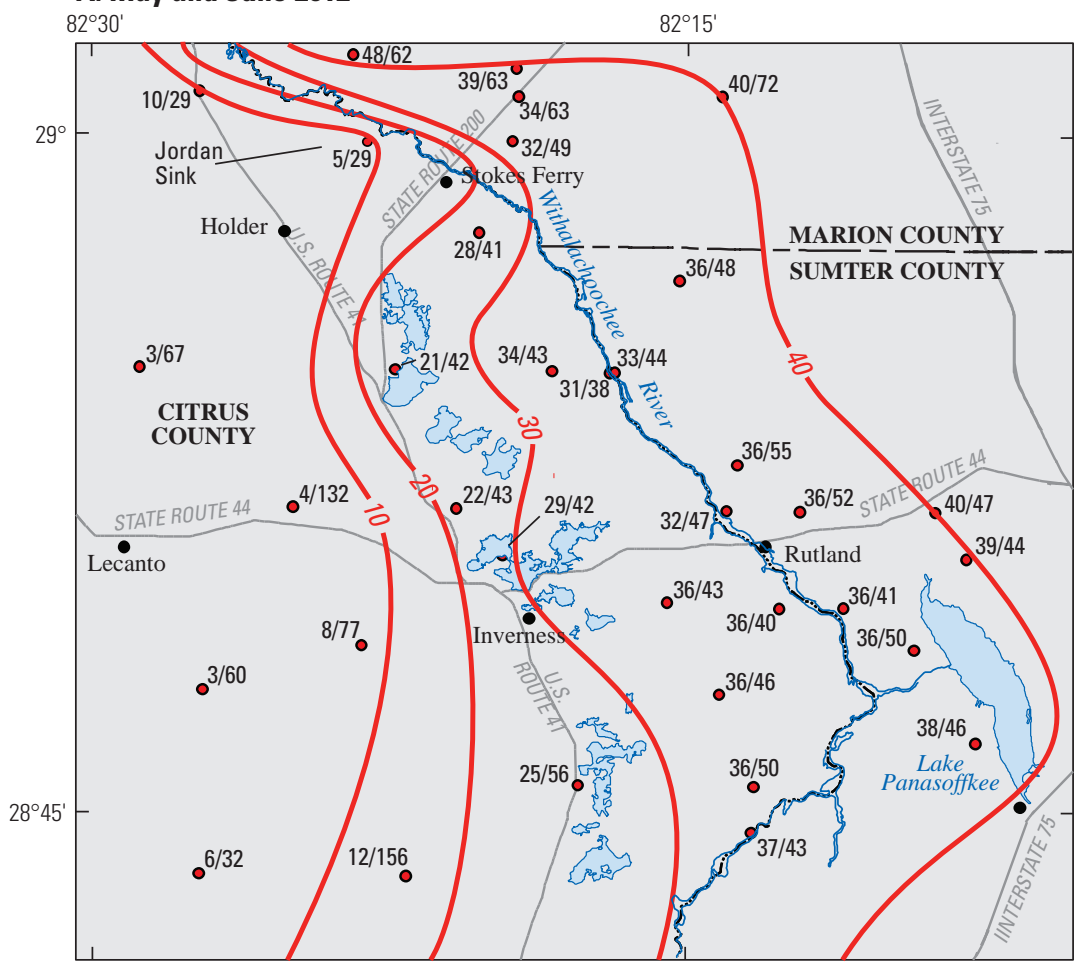

\section{EXPLANATION}

Potentiometric surface contour-Shows level that water would have risen to in tightly cased wells tapping the Upper Floridan aquifer. Interval is 10 feet. Datum is North American Vertical Datum of 1988 (NAVD 88). Dashed line indicates area where there is uncertainty in the contour interval.

40/60 Observation well-First number indicates elevation of water level and second is land-surface elevation. Both are in feet above NAVD 88. Measurements were made in May and June 2012.

40/60 Observation well—First number indicates elevation of water level and second is land-surface elevation. Both are in feet above NAVD 88. Measurements were made in September and October 2012

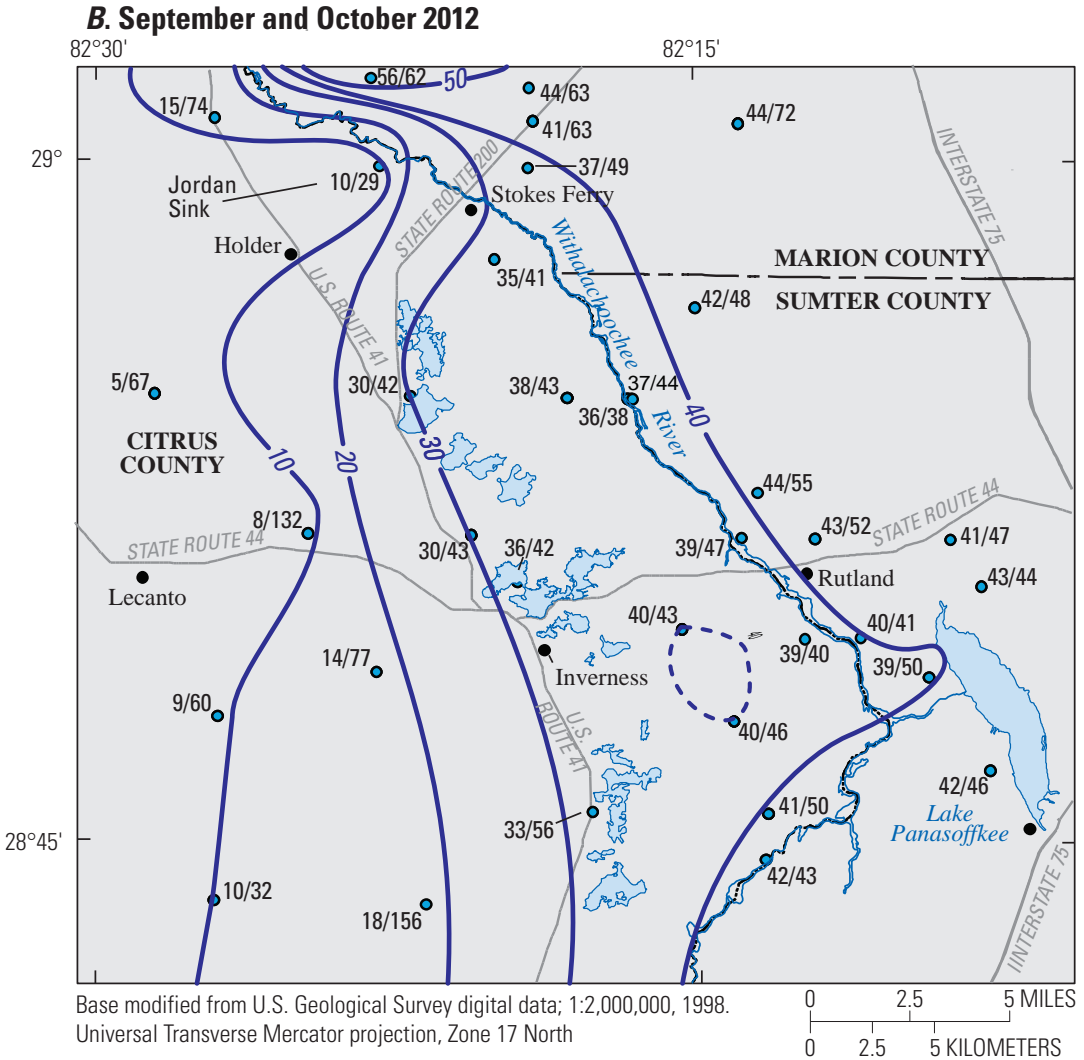

Figure 18. Potentiometric surface of the Upper Floridan aquifer in the Tsala Apopka Lake study area during the A, May-June 2012 dry period and B, September-0ctober 2012 wet period. 


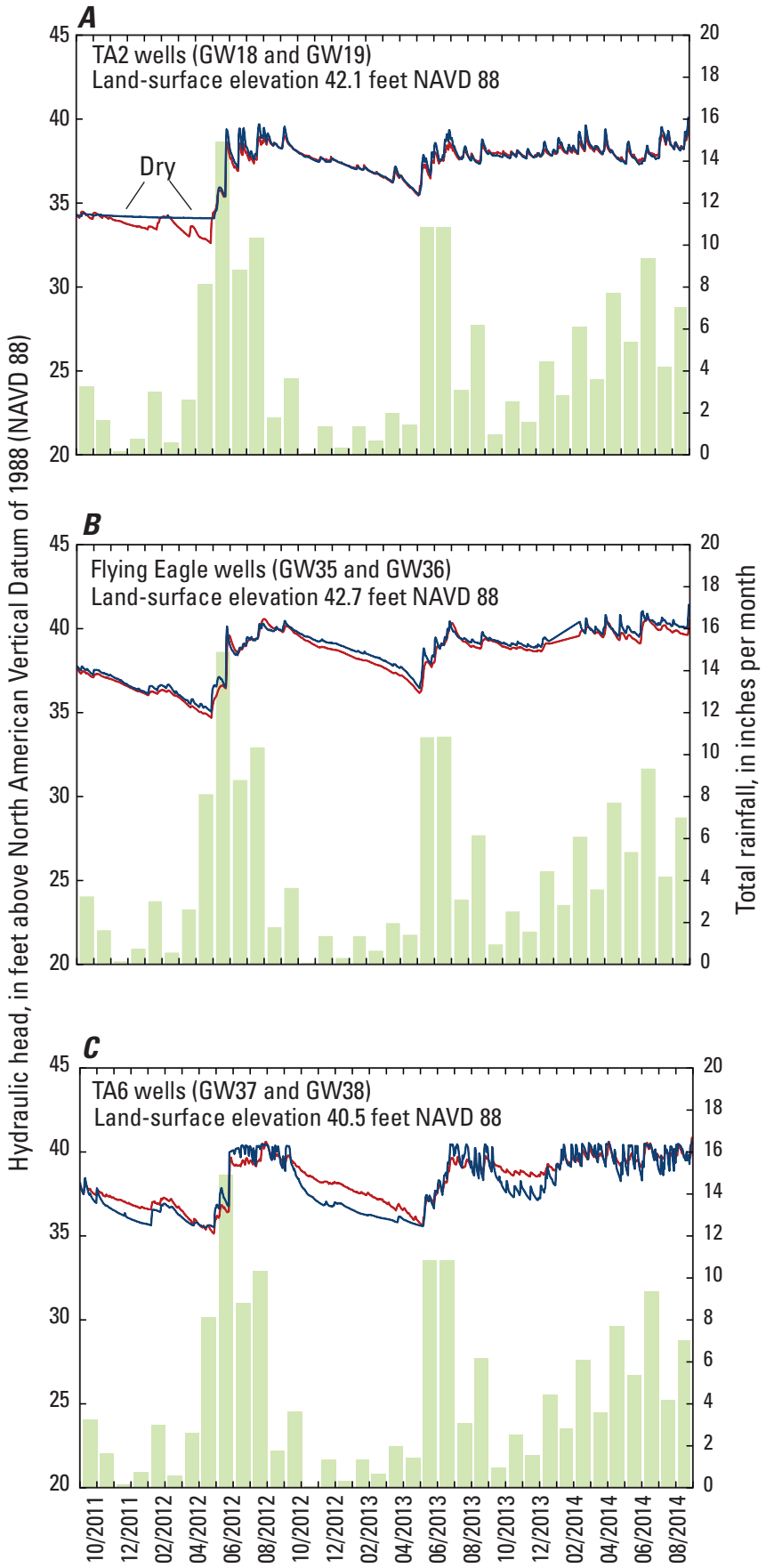

Date

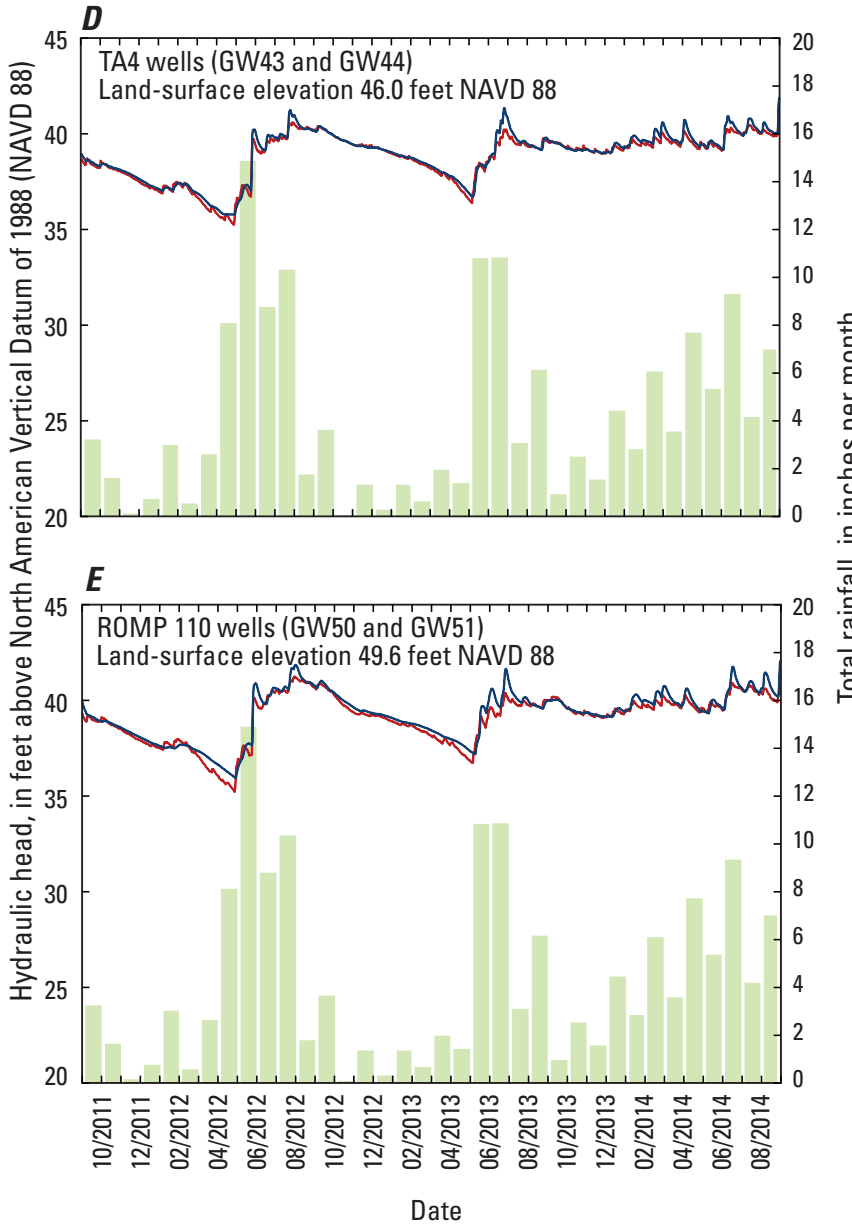

EXPLANATION

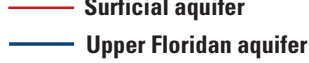

Figure 19. Hydraulic head at paired well sites $A$, TA2 SA and UFA; $B$, Flying Eagle SA and UFA; $C$, TA6 SA and UFA; $D$, TA4 SA and UFA; and $E$, ROMP 110 SA and UFA (Southwest Florida Water Management District, 2017c) compared to total monthly rainfall at the Inverness 3 SE weather station (National Oceanic and Atmospheric Administration, 2015b), October 2011-September 2014 (see table 1 and fig. 4 for site information). 


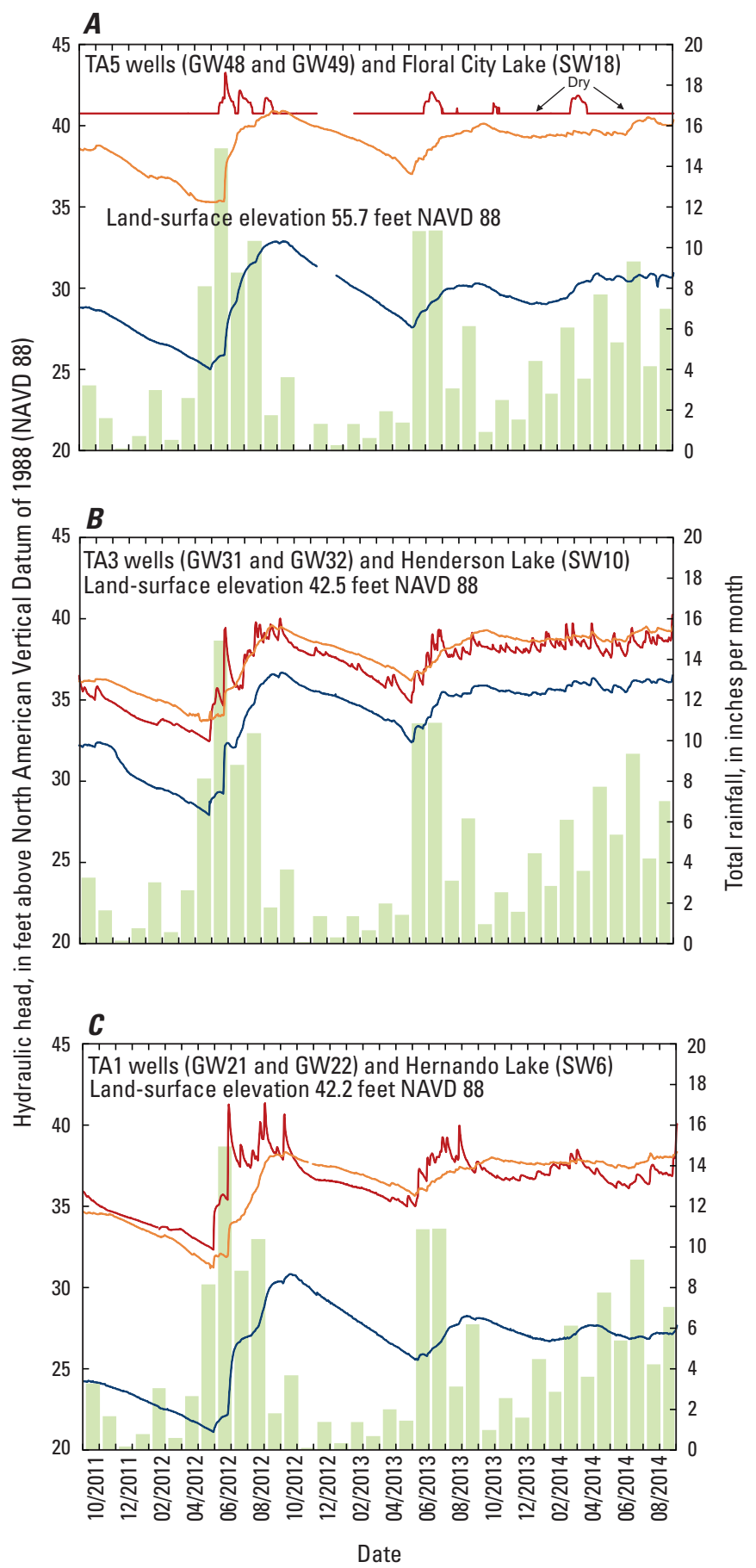

EXPLANATION

Surficial aquifer

- Upper Floridan aquifer

Figure 20. Hydraulic head at paired wells and surface-water stations $A$, TA5 SA and UFA and Floral City Lake; $B$, TA3 SA and UFA and Henderson Lake; and C, TA1 SA and UFA and Hernando Lake (Southwest Florida Water Management District, 2017c) compared to total monthly rainfall at the Inverness 3 SE weather station, October 2011-September 2014 (National Oceanic and Atmospheric Administration, 2015b). See table 1 and figure 4 for site information. response to rainfall, indicating a hydraulic connection from the surficial aquifer to the Upper Floridan aquifer. In the Floral City Pool (fig. 20A) at the TA5 SA site (GW49), the surficial aquifer was mostly dry, with groundwater levels spiking only briefly following heavy rainfall before returning to dry conditions, which is an indication that the surficial aquifer acts merely as a pass-through system in the vicinity of this well, likely because the underlying confining unit (intermediate confining unit) is breached by karst features or is discontinuous. The surficial aquifer only showed brief periods of discharge potential to the major lakes during the study period, when head of the surficial aquifer was higher than that of lake stage during periods of high precipitation. Discharge from the surficial aquifer to the lakes would likely be in the form of lateral flow and diffuse upward flow through the lake bed.

The potentiometric surface of the Upper Floridan aquifer was typically about 3 to $10 \mathrm{ft}$ lower than lake stage, so the Upper Floridan aquifer rarely, if ever, contributes discharge to the lakes in this area. In the Inverness and Hernando Pools (figs. 20B and C), water levels were measurable in surficial aquifer wells (TA1 SA [GW21] and TA3 SA [GW31]) throughout the study period. Based on the similar response of the two aquifers to hydrologic events at these sites, the surficial aquifer and Upper Floridan aquifer seem to be hydraulically connected. Like the Floral City Pool site, lake stages remained higher than Upper Floridan aquifer levels throughout the study period, indicating that the lakes typically have the potential to recharge the Upper Floridan aquifer. In the Inverness Pool, lake stages remained approximately $3 \mathrm{ft}$ higher than the potentiometric surface of the Upper Floridan aquifer, whereas in the Hernando Pool lake stages were usually more than $10 \mathrm{ft}$ higher. Discharge potential was typically highest following major rainfall events when groundwater levels were highest in the surficial aquifer. Also of note for hydrographs for the Inverness and Hernando Pools are the short-term fluctuations in groundwater levels in the surficial aquifer, compared to the smoother nature of the lake hydrographs (figs. 20B and C). This is similarly expressed between hydrographs of groundwater levels in wells and lake levels in Lake Panasoffkee (McBride and others, 2011). This difference might be attributed to the nature of the surficial aquifer, which allows for rapid infiltration, and assuming a specific yield of 0.1 (for unconsolidated clay and sand [Johnson, 1967]) would result in a 10-fold amplification of groundwater-level response when compared to lake response. The gradient between aquifer and lake water levels would result in drainage to the lake and recession in groundwater levels.

West of Tsala Apopka Lake, along the northern section of the Brooksville Ridge, the sediments that constitute the surficial aquifer and intermediate confining unit are thicker than in the lowlands around Tsala Apopka Lake. Throughout the study period, surficial aquifer wells ROMP 109 SA and ROMP 113 SA (figs. 4 and 21, table 1, GW54 and GW26) were dry, except for brief spikes in groundwater level following heavy rainfall. Drilling records from these sites (New, 1980; Decker, 1983) indicate that a confining unit is present that is $15-25 \mathrm{ft}$ thick, but Upper Floridan aquifer groundwater-level data 


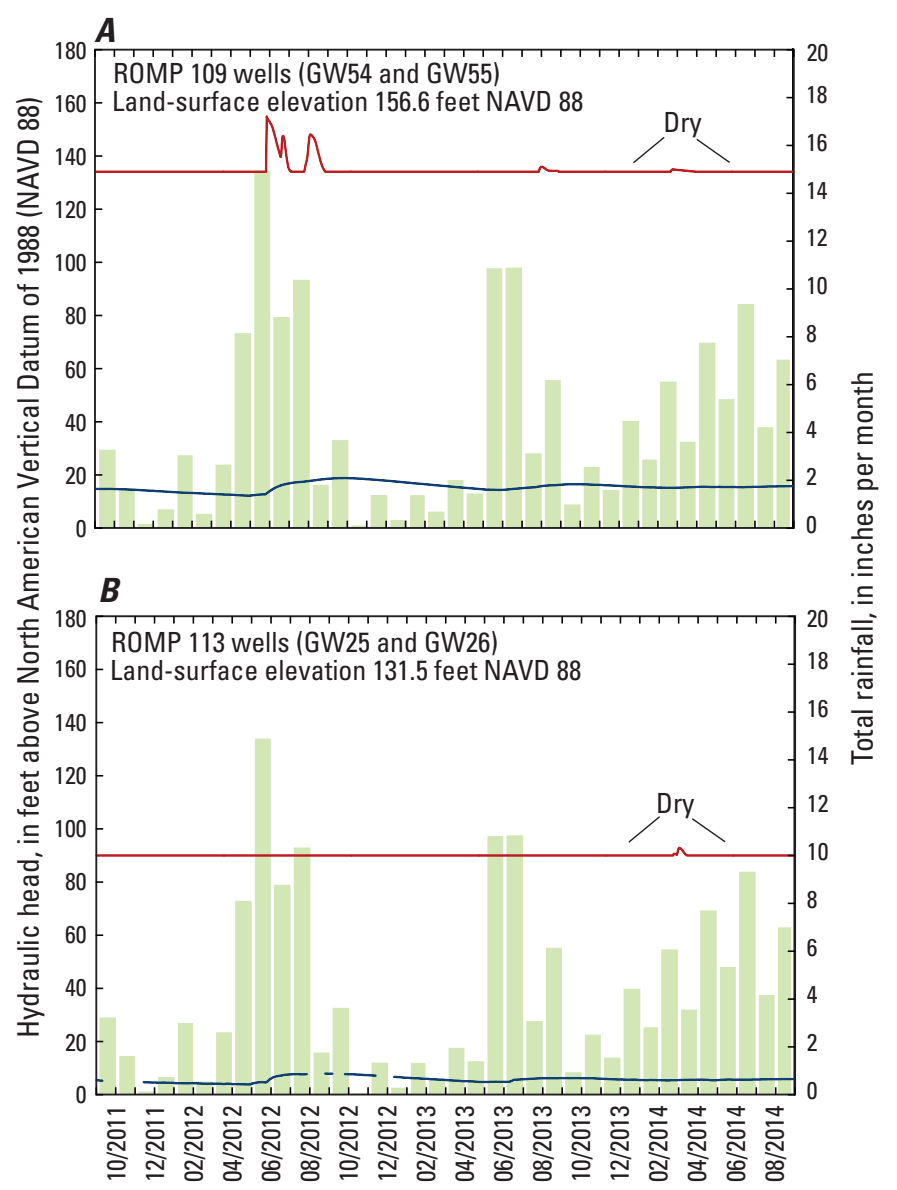

Date

\section{EXPLANATION}

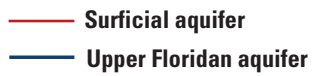

Figure 21. Hydraulic head at paired well sites $A$, ROMP 109 SA and UFA and $B$, ROMP 113 SA and UFA (Southwest Florida Water Management District, 2017c) compared to total monthly rainfall at the Inverness 3 SE weather station, October 2011-September 2014 (National Oceanic and Atmospheric Administration, 2015b). Site information available in table 1 and figure 4.

indicated unconfined conditions. Groundwater levels in the Upper Floridan aquifer were typically lower than the top of limestone (top of the Upper Floridan aquifer) in the ROMP 109 UFA and ROMP 113 UFA wells, and groundwater levels displayed only a muted response to heavy rainfall events, which indicates that the hydraulic conductivity under the ridge is high. Confined aquifers typically have a lag in water-level response to rainfall, which was not the case in the ROMP 109 and 113 UFA wells. When the hydraulic conductivity of an aquifer is very high, recharge is easily dissipated laterally and water levels show little response to recharge events. Extensive karst features, including sinkholes and caves, can be found along the Brooksville Ridge, so secondary porosity likely increases the hydraulic conductivity of the Upper Floridan aquifer in the area (Arthur and others, 2008). The karst features also provide conduits through the confining unit that would enhance recharge. The lack of surface-water features on the ridge, especially channels formed from runoff, indicates that rainfall is mostly internally drained and is a good indication that recharge is high. Sepulveda (2002) determined that some of the highest recharge rates in all of the Upper Floridan aquifer occur in Citrus County.

\section{Jordan Sink}

Jordan Sink is a well-defined karst feature on public land in the Tsala Apopka Lake study area (figs. 1 and 22). It is located approximately $2 \mathrm{mi}$ northwest of the intersection of State Road 200 and the Withlacoochee River, within the Two Mile Prairie tract (fig. 1). Limestone is exposed along the walls of Jordan Sink and a well-developed swallet (an opening through which a stream can flow into the subsurface) is located at the base. The swallet held a small volume of water even under dry conditions throughout the study period (fig. 22A). Flow was observed entering the sinkhole and swallet from Johnson Pond (fig. 1) in May 2012 following heavy rainfall (fig. 22B). The limestone at the base of the sinkhole is well worn and appears to have been subjected to subaerial erosion due to channelized flow (fig. 22C). Based on the erosion of the rocks, Jordan Sink has likely received substantially higher volumes of flow at times prior to the study period, likely from the north and east as the Withlacoochee River overflowed into Johnson Pond. Johnson Pond is connected to Jordan Sink by a natural channel, which turns into a ravine before it empties into the sinkhole and swallet.

The elevation of the potentiometric surface of the Upper Floridan aquifer drops in the vicinity of Jordan Sink (figs. 14 and 18). Water stages in Jordan Sink Pond (figs. 4 and 23, table 1, SW1) and water levels in nearby Jordan Sink UFA monitoring well (GW10) were consistently lower than at the Withlacoochee River near Holder (SW2) and nearby Upper Floridan aquifer monitoring wells ROMP 119.5 UFA and ROMP 116 UFA (GW5 and GW13). The surface-water and groundwater monitoring sites near Jordan Sink maintained water-level elevations of about 26-45 ft during the period of July 8, 2011-August 16, 2013, whereas the elevation in Jordan Sink Pond and Jordan Sink UFA well were similar to one another and varied from about 5 to $10 \mathrm{ft}$ in the same period (fig. 23). The steep hydraulic gradient in the potentiometric surface of the Upper Floridan aquifer in the area of Jordan Sink is likely the result of a zone of low aquifer transmissivity. In parts of an aquifer having lower transmissivity, the potentiometric gradient is steep and contour lines are closely spaced on a potentiometric surface map, as can be seen northeast of Jordan Sink in figure 18. The geology that results in the area of lower transmissivity is unknown. 
$\boldsymbol{A}$
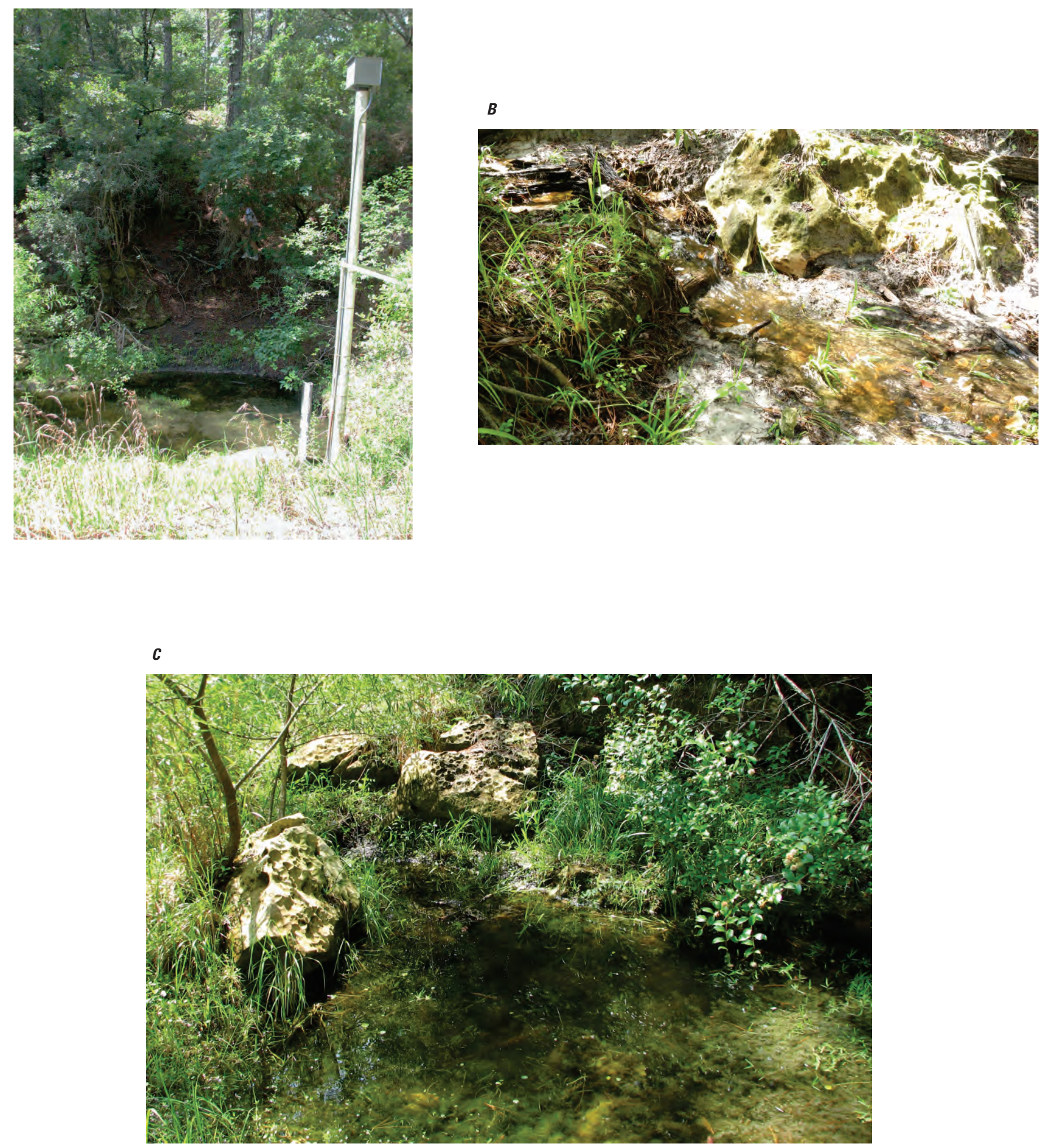

Figure 22. Views of Jordan Sink $A$, from north rim looking down on pond formed in swallet at base of sinkhole; $B$, channelized flow entering the sinkhole in May 2012; and $C$, close up of pond and swallet, and weathered limestone boulders. 


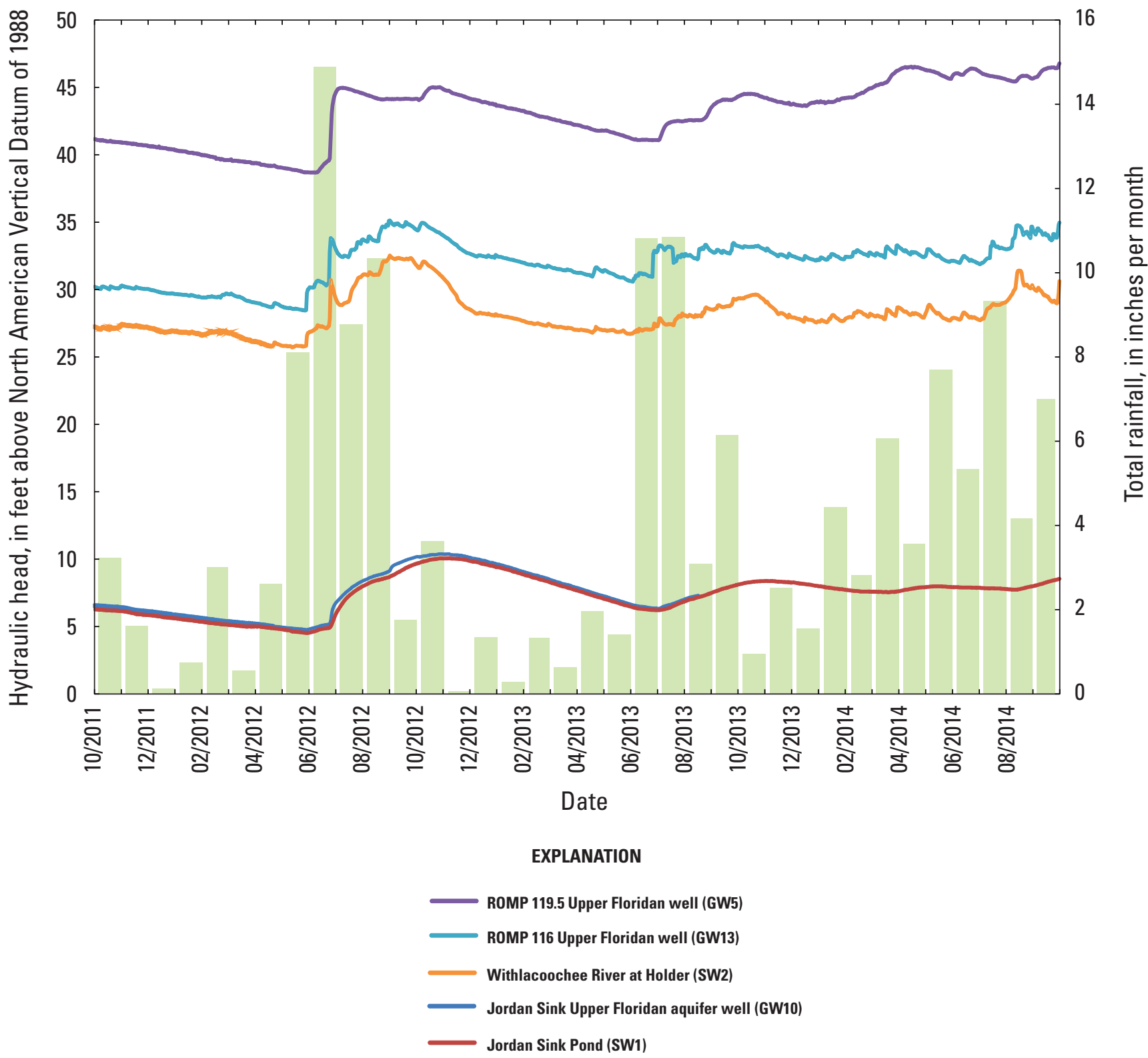

Figure 23. Hydraulic head at Jordan Sink Pond and Jordan Sink Upper Floridan aquifer well compared to nearby Upper Floridan aquifer wells, the Withlacoochee River, and rainfall at the Inverness 3 SE weather station, October 2011-September 2014 (Southwest Florida Water Management District, 2017c; U.S. Geological Survey, 2017a; National Oceanic and Atmospheric Administration, 2015b). Site information available in table 1 and figure 4. 
The gradient of the potentiometric surface of the Upper Floridan aquifer flattens out west of Jordan Sink, likely because groundwater flow in the Upper Floridan aquifer encounters karst features in the area that increase the hydraulic conductivity. Many major karst features, including sinkholes and caves, are along the ridge and are a good example of the effect secondary porosity can have on groundwater flow. Secondary porosity features can greatly increase the hydraulic conductivity of an aquifer. The high recharge rates and flat potentiometric surface under the northern one-half of the Brooksville Ridge and westward are directly related to the extensive karst development in the area.

\section{Geochemistry}

Results of water chemistry, isotopic, and age-dating analyses provide information not available from more traditional methods of hydrologic investigation, such as potentiometric maps and water budgets. Results of the analyses were used to better understand how surface water flows through the Tsala Apopka Lake system, to locate where groundwater and surface-water interactions occur, and to identify sources of water. Age-dating methods were used to determine the mean age of groundwater in the Upper Floridan aquifer and surficial aquifer.

Water samples for geochemical analyses were collected in 2011 and 2012 (table 1), and data are available online for each site at the USGS National Water Information System website (U.S. Geological Survey, 2017a). Conditions in Tsala Apopka Lake were relatively dry prior to the 2011 sampling event and were relatively wet in 2012 based on rainfall data compiled by the National Climatic Data Center (2014) for the NOAA Inverness $3 \mathrm{SE}$ weather station (figs. 8 and 9). The mean annual rainfall at this station from 1930 to 2014 was $54.0 \mathrm{in.}$ In 2011, $48.5 \mathrm{in}$. of rainfall were measured at Inverness $3 \mathrm{SE}$. The 3 years prior to 2011 were also below the mean with annual totals of 49.2, 50.8, and 51.4 in. In 2012, rainfall was slightly above the long-term mean at $55.9 \mathrm{in.}$

The increase in rainfall from 2011 to 2012 is reflected in surface and groundwater levels in the study area. For example, the annual mean streamgage height for 2011 at the USGS Withlacoochee River near Holder streamgage (fig. 4, table 1, SW2) was $27.3 \mathrm{ft}$ (streamflow of 238 cubic feet per second $\left[\mathrm{ft}^{3} / \mathrm{s}\right]$ ), and in 2012 increased $1.3 \mathrm{ft}$ to a streamgage height of $28.6 \mathrm{ft}\left(630 \mathrm{ft}^{3} / \mathrm{s}\right.$; U.S. Geological Survey, 2016). The annual mean groundwater level at the Flying Eagle UFA Upper Floridan aquifer well (GW36) was $37.2 \mathrm{ft}$ in 2011 and increased to $37.7 \mathrm{ft}$ in 2012 (SWFWMD, 2014b).

\section{Major Ions}

The concentration of major ions can be used to identify sampling sites that share similar chemical characteristics. Rainwater contains low concentrations of major ions, but once deposited on land surface the concentrations increase as the water interacts with the minerals contained in rocks and soils. The hydrochemical facies, or "type" of water that develops, depends on the mineralogy of the system. This is especially apparent in the groundwater system, where water is in close contact with aquifer materials.

All of the water-quality sample data, except for one site, indicate a calcium-bicarbonate type water (fig. 24). The primary source of calcium-bicarbonate in the study area is the limestone of the Upper Floridan aquifer, but it is not unusual for surface water and shallow groundwater to also be of this type, though typically less chemically mature, because limestone and shell fragments are commonly found on land surface and in the surficial aquifer. Another source of calcium bicarbonate at Tsala Apopka Lake is the Withlacoochee River. Rivers often contain water with low concentrations of major ions, especially during the wet season, because the source of the water is runoff from rainfall, but previous studies have determined that the Withlacoochee River receives considerable inflow directly from the Upper Floridan aquifer from both spring discharge and diffuse groundwater seepage through the river bed (Trommer and others, 2009; McBride and others, 2011). All of the large lakes that constitute the Tsala Apopka Lake system are connected to the river by a series of canals. During periods of high flow this calcium-bicarbonate-rich river water inundates the canals and lakes of Tsala Apopka Lake, where it mixes with water of meteoric origins. A fraction of this water eventually recharges the groundwater system. The ROMP 112 UFA Upper Floridan aquifer well (fig. 4, table 1, GW23), located near the center of the study area, was the only site to produce calcium-sulfate type water. There is an area in the Upper Floridan aquifer within Marion, Sumter, and Citrus Counties known to produce water containing high concentrations of sulfate. For more information regarding wells that produce calcium-sulfate type water in these areas see Sacks (1996).

Water samples collected from the Upper Floridan aquifer tended to have the highest concentrations of major ions, though the concentrations varied considerably depending on the physiographic setting of the sampling sites (figs. 10 and 25). Samples collected from Upper Floridan aquifer wells in the lowlands tended to have the highest concentrations of major ions, whereas samples collected from the highlands north and west of the Tsala Apopka Plain tended to have lower concentrations. The samples from the uplands are likely less hydrochemically mature, which might indicate that groundwater in this area has been in contact with the calcium bicarbonate aquifer materials of the Upper Floridan aquifer for less time than in the lowlands. In the lowlands, groundwater flow is likely slower because of the flatter gradient and, possibly, lower hydraulic conductivity in the aquifer.

Water samples collected from the surficial aquifer, canals, and lakes tended to be less hydrochemically mature than the samples collected from the Upper Floridan aquifer or Withlacoochee River, but there was one exception. The sample collected from Jordan Sink Pond (figs. 4 and 25, table 1, SW1) 
EXPLANATION

$\checkmark \quad$ Upper Floridan aquifer

Surficial aquifer

- Lakes and ponds

$\triangle \quad$ Streams

$\diamond \quad$ Canals
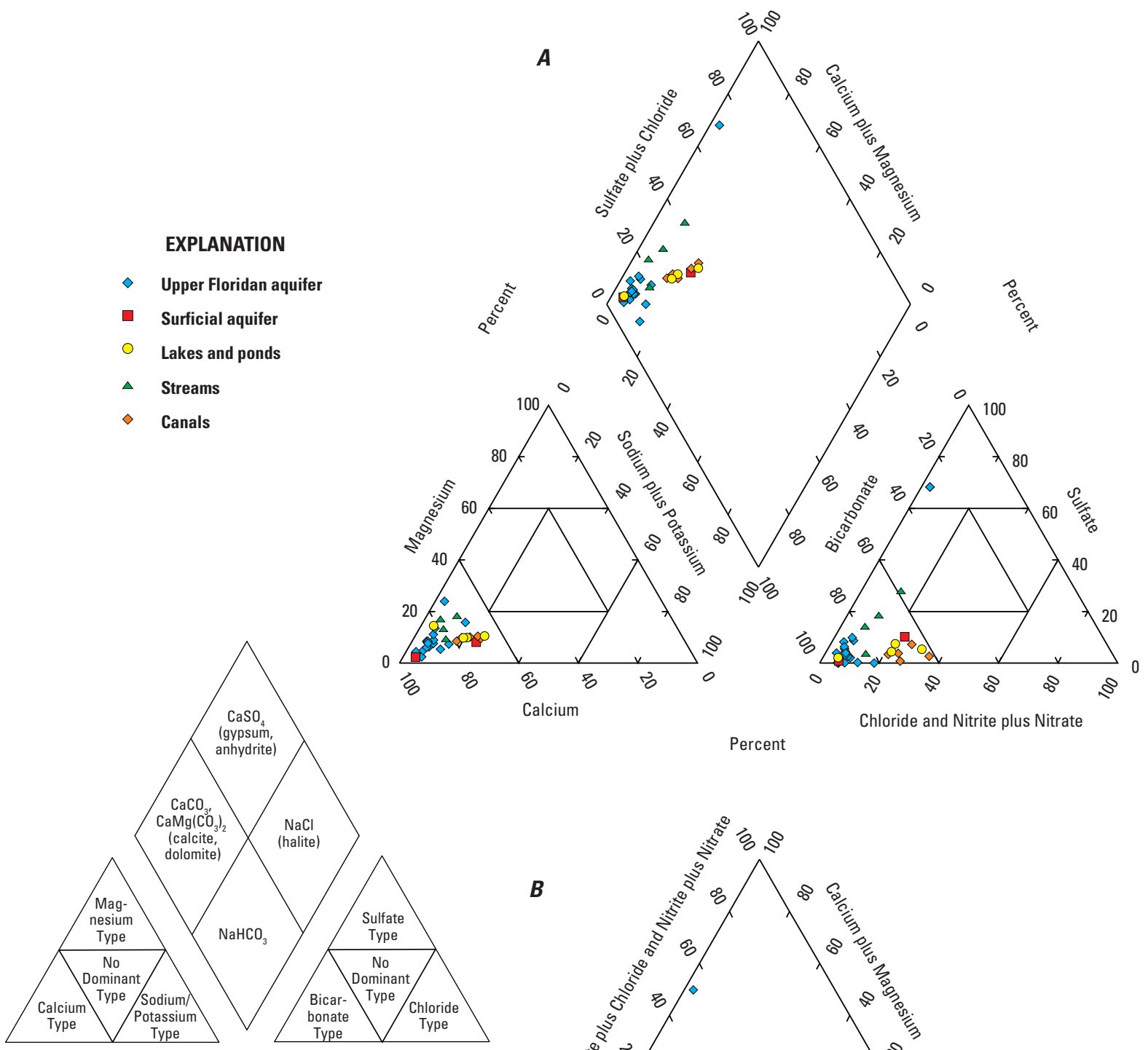

0

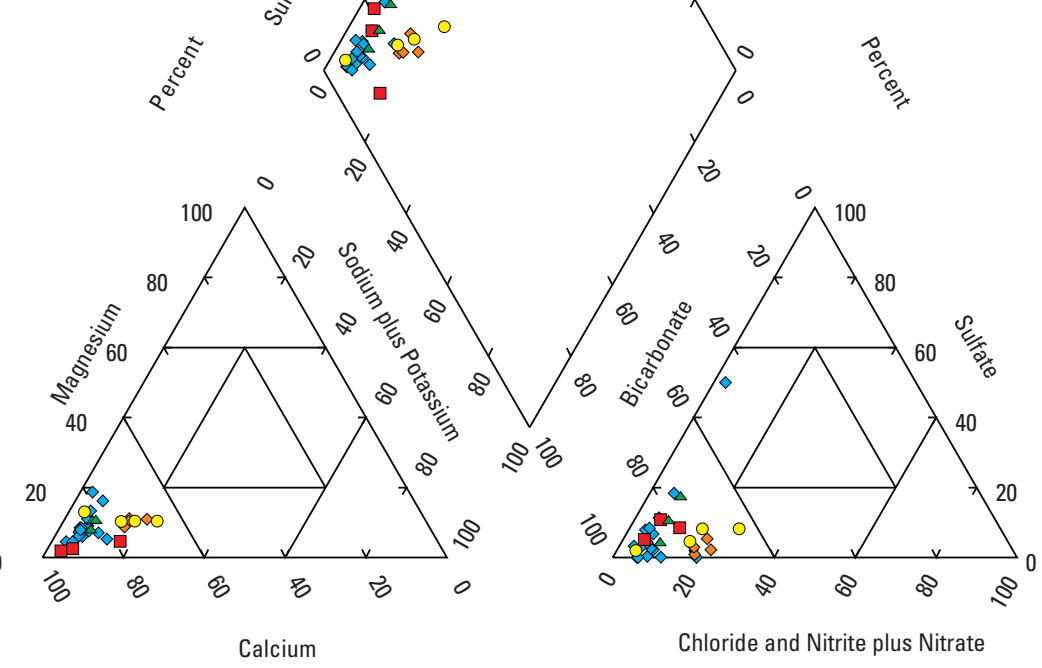

Percent

Figure 24. Trilinear diagrams depicting water types by water source for major-ion samples collected in the Tsala Apopka Lake study area during A, December 2011 and B, December 2012. 
$\boldsymbol{A}$

$82^{\circ} 20^{\prime}$

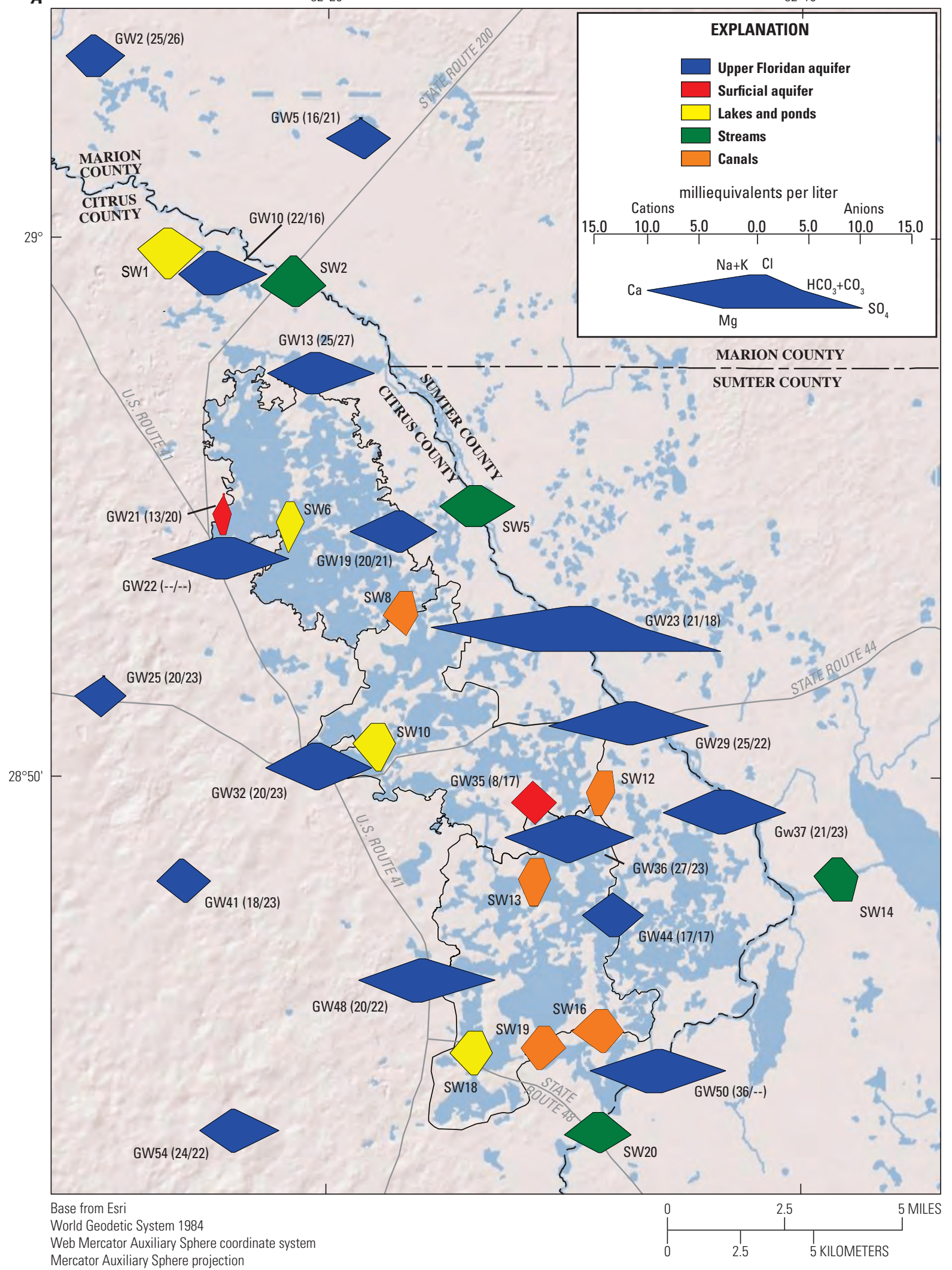

Figure 25. Stiff diagrams depicting water types by sample for major-ion samples collected in the Tsala Apopka Lake study area during $A$, December 2011 and $B$, December 2012. See table 1 for site descriptions and figure 4 for precise site locations. The apparent recharge ages of groundwater samples are listed following the site identifier. The ages are based on sulfur hexafluoride and tritium data, respectively. [Na, sodium; $\mathrm{K}$, potassium; $\mathrm{Cl}$, chloride; $\mathrm{HCO}_{3^{\prime}}$, bicarbonate; $\mathrm{CO}_{3^{\prime}}$ carbonate; $\mathrm{SO}_{4^{\prime}}$ sulfate; $\mathrm{Mg}$, magnesium; $\mathrm{Ca}$, calcium] 


\section{$B$}

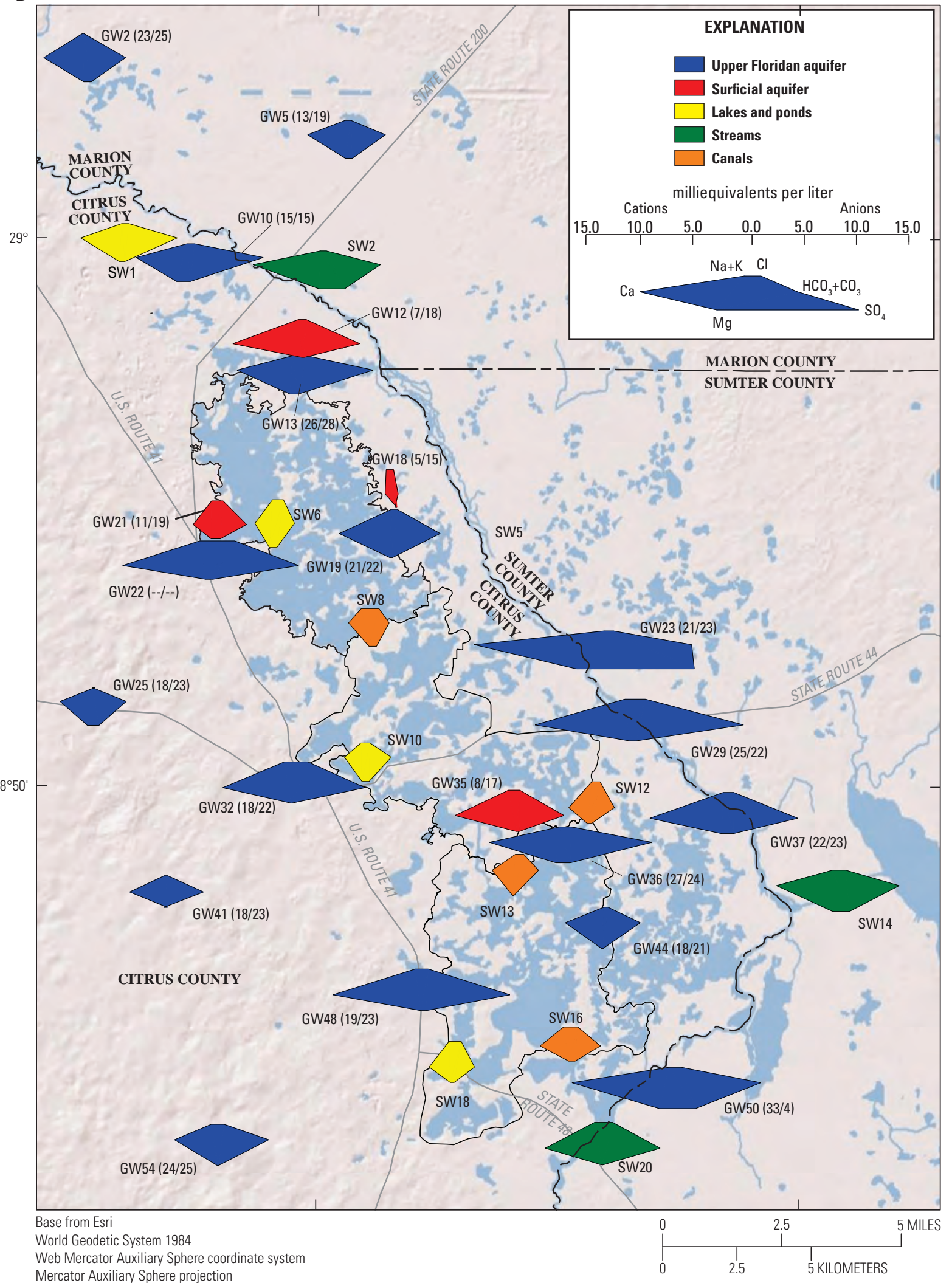

Figure 25. Stiff diagrams depicting water types by sample for major-ion samples collected in the Tsala Apopka Lake study area during $A$, December 2011 and $B$, December 2012. See table 1 for site descriptions and figure 4 for precise site locations. The apparent recharge ages of groundwater samples are listed following the site identifier. The ages are based on sulfur hexafluoride and tritium data, respectively. [ $\mathrm{Na}$, sodium; $\mathrm{K}$, potassium; $\mathrm{Cl}$, chloride; $\mathrm{HCO}_{3^{\prime}}$, bicarbonate; $\mathrm{CO}_{3^{\prime}}$ carbonate; $\mathrm{SO}_{4}$, sulfate; $\mathrm{Mg}$, magnesium; $\mathrm{Ca}$, calcium]—Continued 
had a Stiff pattern that indicated more mature water than other lake and pond water samples and was similar in major ion concentration to Upper Floridan aquifer samples collected in the uplands. This exception might be attributed to the pond being situated at the bottom of a sinkhole where limestone crops out. The pond was an expression of the water level of the Upper Floridan aquifer based on a comparison of waterlevel data collected there and at nearby Jordan Sink UFA well (fig. 4, table 1, GW10).

\section{Isotopes}

Isotopic analyses are valuable tools for determining water sources and for establishing flowpaths. In many systems, it is possible to use major ion chemistry alone to accomplish these tasks, but in a complex system such as Tsala Apopka Lake, where major ion chemistry is similar throughout, isotopes give additional insight into the mechanics of a hydrologic system that might not otherwise be possible.

\section{Strontium}

Most of the groundwater and surface water sampled from the Tsala Apopka Lake pools in 2011 and 2012 had ${ }^{87} \mathrm{Sr} /{ }^{86} \mathrm{Sr}$ ratios similar to the rocks of the Upper Floridan aquifer (fig. 26, table 3). Cores of Ocala Limestone were analyzed by Katz and Bullen (1996) and they determined that the ${ }^{87} \mathrm{Sr} /{ }^{86} \mathrm{Sr}$ ratio varied from 0.7081 to 0.7085 . DePaolo and Ingram (1985) did similar analyses on the rocks of the underlying Avon Park Formation and determined the ${ }^{87} \mathrm{Sr} /{ }^{86} \mathrm{Sr}$ ratio ranged from 0.7077 to 0.7078 . The ${ }^{87} \mathrm{Sr} /{ }^{86} \mathrm{Sr}$ ratio was inversely related to the age of the rocks; that is, older rocks have lower isotopic ratios. In $2011,{ }^{87} \mathrm{Sr} /{ }^{86} \mathrm{Sr}$ ratios of surface-water samples ranged from 0.70788 to 0.70821 and in 2012, from 0.70786 to 0.70820 . The isotopic ratio of groundwater samples varied from 0.70779 to 0.70884 in 2011 and from 0.70781 to 0.70940 in 2012.

All of the water samples collected in 2011 contained ${ }^{87} \mathrm{Sr} /{ }^{86} \mathrm{Sr}$ ratios consistent with carbonate rocks from the Upper Floridan aquifer, except the water sample from the GW21 well, which is the surficial aquifer well TA1 SA (figs. 4 and 26 , tables 1 and 3). The water from the GW21 well had ${ }^{87} \mathrm{Sr} /{ }^{86} \mathrm{Sr}$ ratios typical of samples taken from the sediments of the surficial aquifer. Even though most of the Upper Floridan aquifer wells were finished in the Ocala Limestone (table 4), the ${ }^{87} \mathrm{Sr} /{ }^{86} \mathrm{Sr}$ ratios of samples collected from wells installed in the Upper Floridan aquifer fell in the transition between the range of the Avon Park Formation and the Ocala Limestone, or within the range of the Avon Park Formation. The exceptions were samples from Upper Floridan aquifer wells CE-14 UFA (GW2) in 2011 and ROMP 119.5 UFA (GW5) in 2011 and 2012, which fell in the range of the Ocala Limestone. The exceptions can be explained in that the Ocala Limestone is generally thin in the vicinity of Tsala Apopka Lake. The top of the Avon Park Formation (bottom of the Ocala Limestone) is sometimes as little as $20 \mathrm{ft}$ bls, so it is expected that the bulk of the Upper Floridan aquifer samples contain mixtures of water that have been in contact with the Avon Park Formation and the Ocala Limestone. It is also possible that some of the wells are partially finished in the Avon Park Formation and produce a mixture of water from both formations. Although drilling records indicate that most of the wells are finished entirely in the Ocala Limestone, the disconformity at the boundary between the Avon Park Formation and Ocala Limestone can make the transition difficult to identify based on drill cuttings alone (Jason LaRoche, SWFWMD, oral commun., 2012). Samples from GW2 and GW5, wells located in the north of the study area, contained ${ }^{87} \mathrm{Sr} /{ }^{86} \mathrm{Sr}$ ratios consistent with Ocala Limestone. These wells are both greater than $200 \mathrm{ft}$ in depth and are open to the Avon Park Formation and the Ocala Limestone. Data from these samples likely reflect the lower productivity of the Avon Park Formation compared to the Ocala Limestone.

The surface-water samples from streams and lakes collected in 2011 all seem to contain groundwater sources based on their ${ }^{87} \mathrm{Sr} /{ }^{86} \mathrm{Sr}$ ratios. Samples collected from streams, including the Withlacoochee River (fig. 4, table 1, SW2 and SW20), Gum Slough (SW5), and Outlet River (SW14), all contained ${ }^{87} \mathrm{Sr} /{ }^{86} \mathrm{Sr}$ ratios consistent with a mixture of water originating from the Avon Park Formation and Ocala Limestone. Previous studies determined that much of the discharge from these streams originates from groundwater sources (Trommer and others, 2009; McBride and others, 2011). Three samples were analyzed from large lakes in the Tsala Apopka Lake chain-of-lakes, including one lake sample from each of the three pools. Samples from Floral City Lake (SW18) and Henderson Lake (SW10), located in the Floral City and Inverness Pools, respectively, contained ${ }^{87} \mathrm{Sr} /{ }^{86} \mathrm{Sr}$ ratios consistent with Ocala Limestone groundwater. The sample from Hernando Lake (SW6), located in the Hernando Pool, contained an ${ }^{87} \mathrm{Sr} /{ }^{86} \mathrm{Sr}$ ratio consistent with mixed Avon Park Formation and Ocala Limestone groundwater. All of the large lakes in the Tsala Apopka Lake chain-of-lakes are interconnected through a series of canals that receive flow from the Withlacoochee River during wet periods. The river water, as discussed above, contained a large fraction of water from the Upper Floridan aquifer. Groundwater-level data collected from paired Upper Floridan aquifer and surficial aquifer wells (fig. 20) indicate that the Upper Floridan aquifer rarely, if ever, discharges (provides base flow) to the major lakes, so the Upper Floridan aquifer water likely discharged to the Withlacoochee River in reaches upstream from Tsala Apopka Lake before it was diverted into the canals and lakes.

Samples collected from the major lakes and canals tended to contain slightly higher ${ }^{87} \mathrm{Sr} /{ }^{86} \mathrm{Sr}$ ratios and strontium concentrations than samples collected from the Upper Floridan aquifer and Withlacoochee River (fig. 26). A similar trend was identified when ${ }^{87} \mathrm{Sr} /{ }^{86} \mathrm{Sr}$ ratios were compared to chloride concentrations (fig. 27). The increase in concentration of strontium and chloride ions is likely caused by concentration as water evaporates from the lakes and 

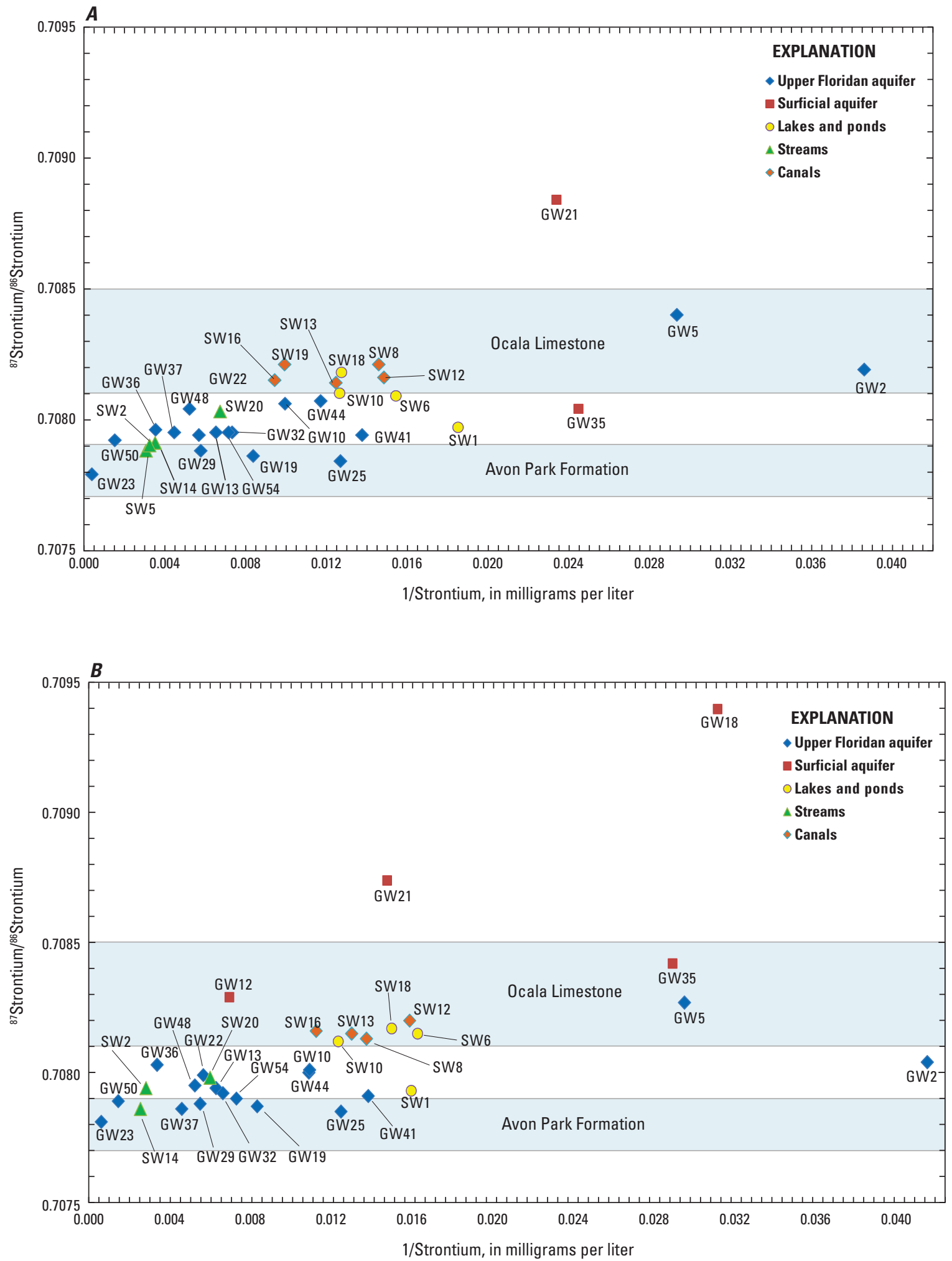

Figure 26. Relation between strontium isotope ratios and the reciprocal of the strontium concentration in water samples from the Tsala Apopka Lake study area for $A$, December 2011 and B, December 2012. See table 1 for site descriptions and figure 4 for site locations. 
Table 3. Strontium, hydrogen, and oxygen isotope data collected from select groundwater and surface-water sites in the Tsala Apopka Lake study area, December 2011 and December 2012.

[USGS, U.S. Geological Survey; yyyy/mm/dd, year/month/day; EST, Eastern Standard Time; per mil, parts per thousand; GW, groundwater; UFA, Upper Floridan aquifer; SA, surficial aquifer; SW, surface water]

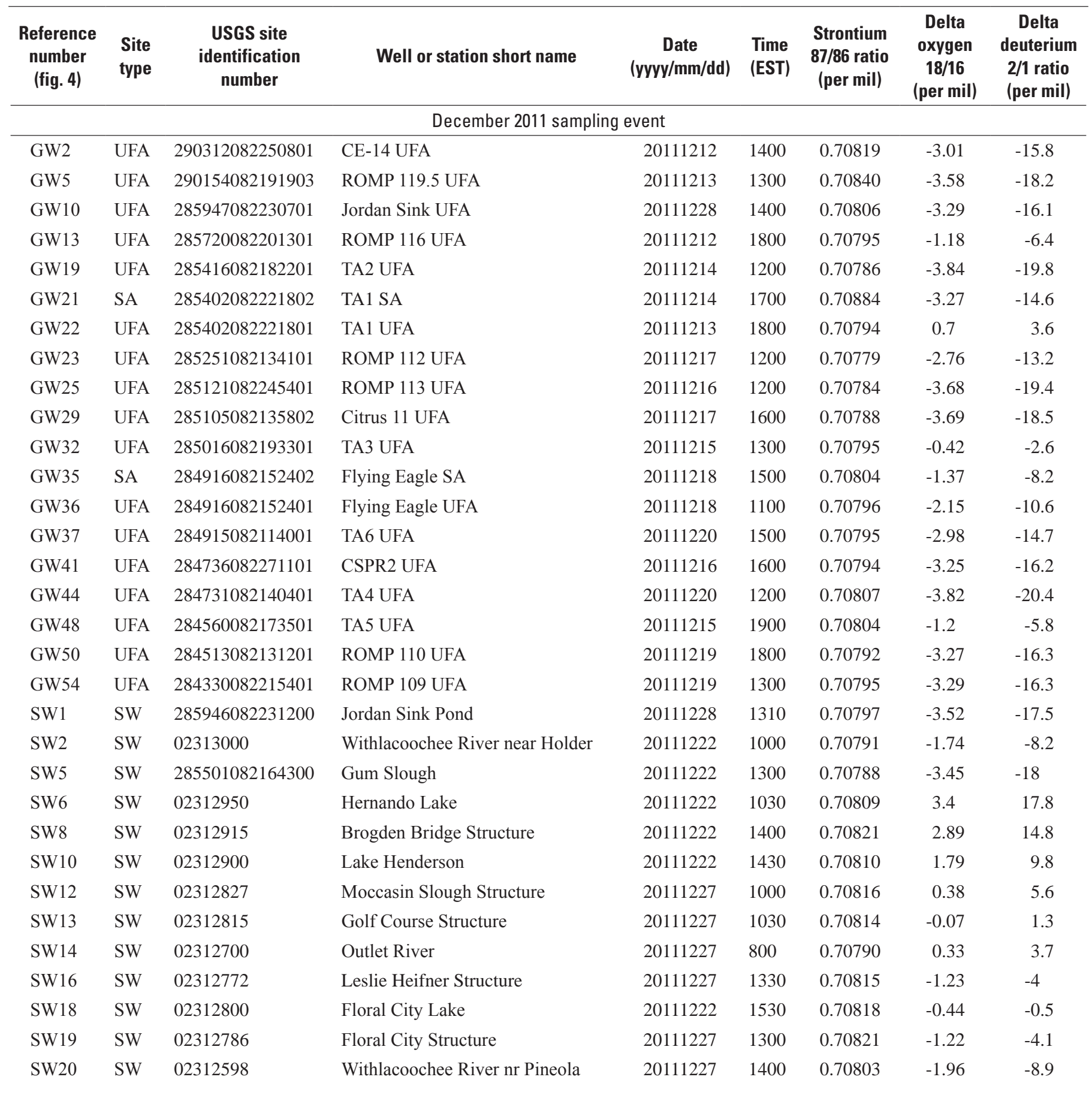


Table 3. Strontium, hydrogen, and oxygen isotope data collected from select groundwater and surface-water sites in the Tsala Apopka Lake study area, December 2011 and December 2012.-Continued

[USGS, U.S. Geological Survey; yyyy/mm/dd, year/month/day; EST, Eastern Standard Time; per mil, parts per thousand; GW, groundwater; UFA, Upper Floridan aquifer; SA, surficial aquifer; SW, surface water]

\begin{tabular}{|c|c|c|c|c|c|c|c|c|}
\hline $\begin{array}{l}\text { Reference } \\
\text { number } \\
\text { (fig. 4) }\end{array}$ & $\begin{array}{l}\text { Site } \\
\text { type }\end{array}$ & $\begin{array}{l}\text { USGS site } \\
\text { identification } \\
\text { number }\end{array}$ & Well or station short name & $\begin{array}{c}\text { Date } \\
\text { (yyyy/mm/dd) }\end{array}$ & $\begin{array}{l}\text { Time } \\
\text { (EST) }\end{array}$ & $\begin{array}{c}\text { Strontium } \\
87 / 86 \text { ratio } \\
\text { (per mil) }\end{array}$ & $\begin{array}{c}\text { Delta } \\
\text { oxygen } \\
18 / 16 \\
\text { (per mil) } \\
\end{array}$ & $\begin{array}{c}\text { Delta } \\
\text { deuterium } \\
2 / 1 \text { ratio } \\
\text { (per mil) }\end{array}$ \\
\hline \multicolumn{9}{|c|}{ December 2012 sampling event } \\
\hline GW2 & UFA & 290312082250801 & CE-14 UFA & 20121203 & 1400 & 0.70804 & -3.02 & -16.3 \\
\hline GW5 & UFA & 290154082191903 & ROMP 119.5 UFA & 20121204 & 1300 & 0.70827 & -3.52 & -18.6 \\
\hline GW10 & UFA & 285947082230701 & Jordan Sink UFA & 20121203 & 1700 & 0.70801 & -3.35 & -17.7 \\
\hline GW12 & SA & 285720082201302 & ROMP $116 \mathrm{SA}$ & 20121204 & 1900 & 0.70829 & -2.57 & -16.8 \\
\hline GW13 & UFA & 285720082201301 & ROMP 116 UFA & 20121204 & 1700 & 0.70794 & -1.18 & -6.4 \\
\hline GW18 & SA & 285416082182202 & TA2 SA & 20121210 & 1600 & 0.70940 & -4.08 & -23.3 \\
\hline GW19 & UFA & 285416082182201 & TA2 UFA & 20121210 & 1200 & 0.70787 & -3.71 & -18.9 \\
\hline GW21 & SA & 285402082221802 & TA1 SA & 20121205 & 1600 & 0.70874 & -5.26 & -32 \\
\hline GW22 & UFA & 285402082221801 & TA1 UFA & 20121205 & 1200 & 0.70799 & 0.29 & 2 \\
\hline GW23 & UFA & 285251082134101 & ROMP 112 UFA & 20121206 & 1100 & 0.70781 & -2.92 & -14.7 \\
\hline GW25 & UFA & 285121082245401 & ROMP 113 UFA & 20121212 & 1100 & 0.70785 & -3.67 & -17.7 \\
\hline GW29 & UFA & 285105082135802 & Citrus 11 UFA & 20121206 & 1600 & 0.70788 & -3.63 & -18.2 \\
\hline GW32 & UFA & 285016082193301 & TA3 UFA & 20121217 & 1600 & 0.70792 & -0.36 & -2 \\
\hline GW35 & SA & 284916082152402 & Flying Eagle SA & 20121212 & 1700 & 0.70842 & -2.41 & -12.5 \\
\hline GW36 & UFA & 284916082152401 & Flying Eagle UFA & 20121212 & 1500 & 0.70803 & -2.01 & -9 \\
\hline GW37 & UFA & 284915082114001 & TA6 UFA & 20121214 & 1500 & 0.70786 & -3.02 & -15.6 \\
\hline GW41 & UFA & 284736082271101 & CSPR2 UFA & 20121214 & 1100 & 0.70791 & -3.16 & -16 \\
\hline GW44 & UFA & 284731082140401 & TA4 UFA & 20121214 & 1800 & 0.70800 & -3.67 & -18.5 \\
\hline GW48 & UFA & 284560082173501 & TA5 UFA & 20121217 & 1100 & 0.70795 & -1.2 & -6.1 \\
\hline GW50 & UFA & 284513082131201 & ROMP 110 UFA & 20121213 & 1700 & 0.70789 & -3.26 & -16.1 \\
\hline GW54 & UFA & 284330082215401 & ROMP 109 UFA & 20121213 & 1200 & 0.70790 & -3.24 & -16.4 \\
\hline SW1 & SW & 285946082231200 & Jordan Sink Pond & 20121218 & 1130 & 0.70793 & -3.63 & -18.5 \\
\hline SW2 & SW & 02313000 & Withlacoochee River near Holder & 20121218 & 1000 & 0.70794 & -2.4 & -11.9 \\
\hline SW6 & SW & 02312950 & Hernando Lake & 20121218 & 1200 & 0.70815 & 0.75 & 2.9 \\
\hline SW8 & SW & 02312915 & Brogden Bridge Structure & 20121218 & 1330 & 0.70813 & 0.3 & 0.6 \\
\hline SW10 & SW & 02312900 & Lake Henderson & 20121218 & 1430 & 0.70812 & -0.4 & -3.8 \\
\hline SW12 & SW & 02312827 & Moccasin Slough Structure & 20121219 & 1000 & 0.70820 & -0.81 & -4.1 \\
\hline SW13 & SW & 02312815 & Golf Course Structure & 20121219 & 1100 & 0.70815 & -0.72 & -4.6 \\
\hline SW14 & SW & 02312700 & Outlet River & 20121219 & 900 & 0.70786 & -1.31 & -6.2 \\
\hline SW16 & SW & 02312772 & Leslie Heifner Structure & 20121219 & 1300 & 0.70816 & -1.52 & -8.3 \\
\hline SW18 & SW & 02312800 & Floral City Lake & 20121218 & 1500 & 0.70817 & -1.16 & -5.8 \\
\hline SW20 & SW & 02312598 & Withlacoochee River near Pineola & 20121219 & 1400 & 0.70798 & -2.24 & -11 \\
\hline
\end{tabular}




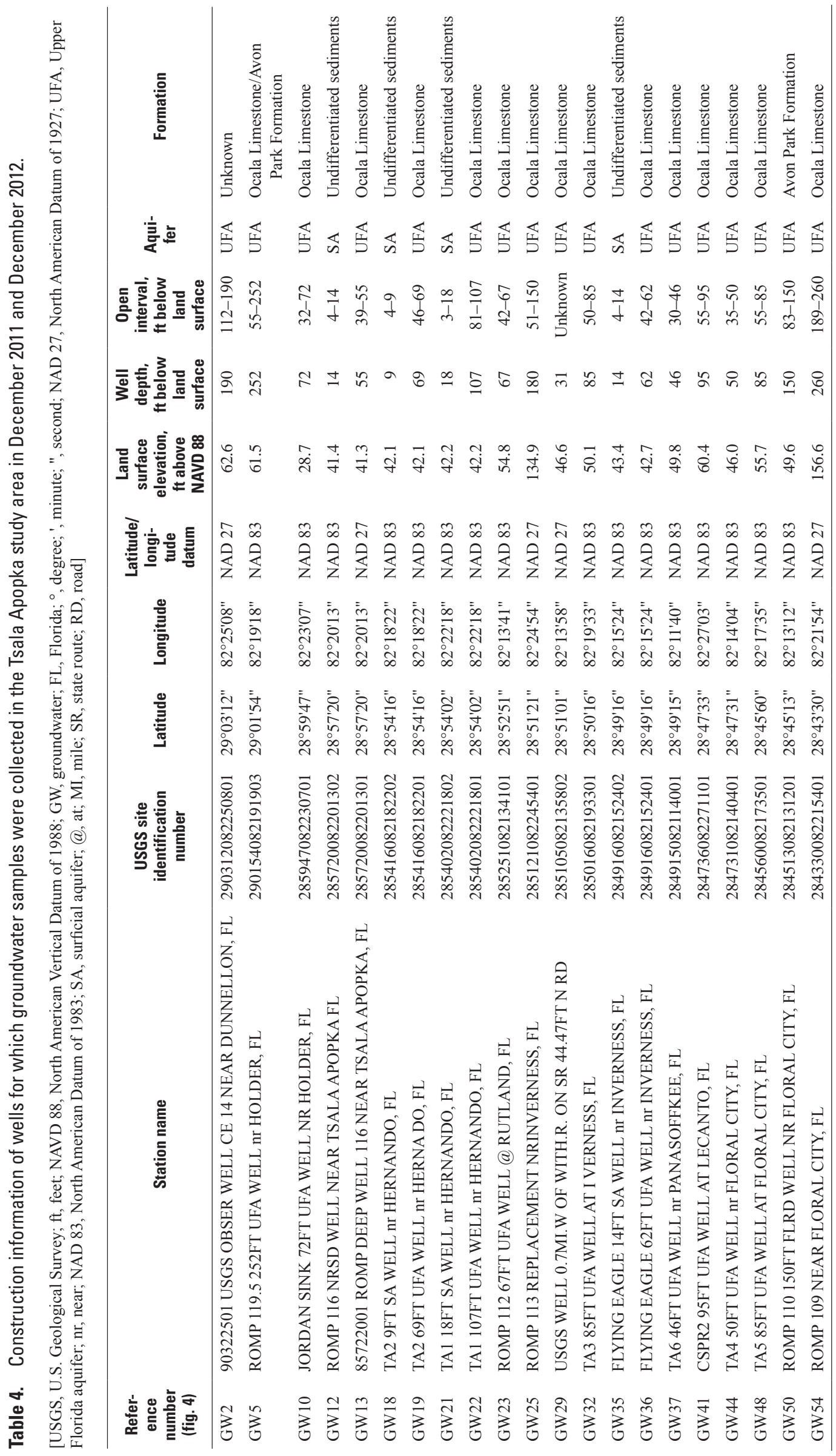



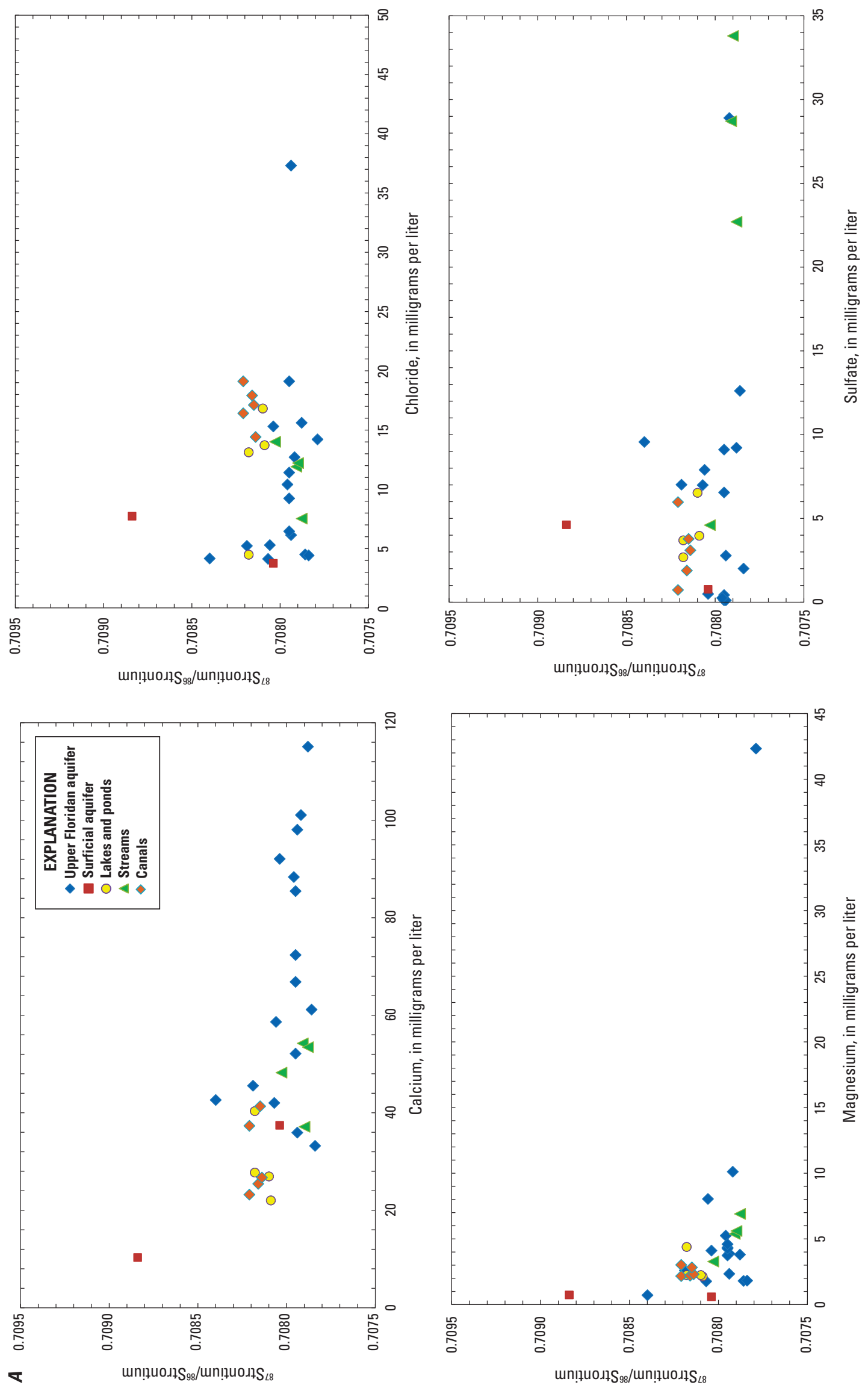

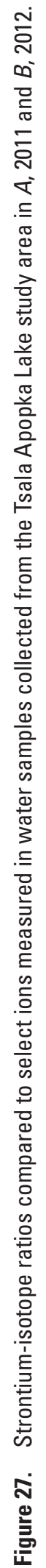



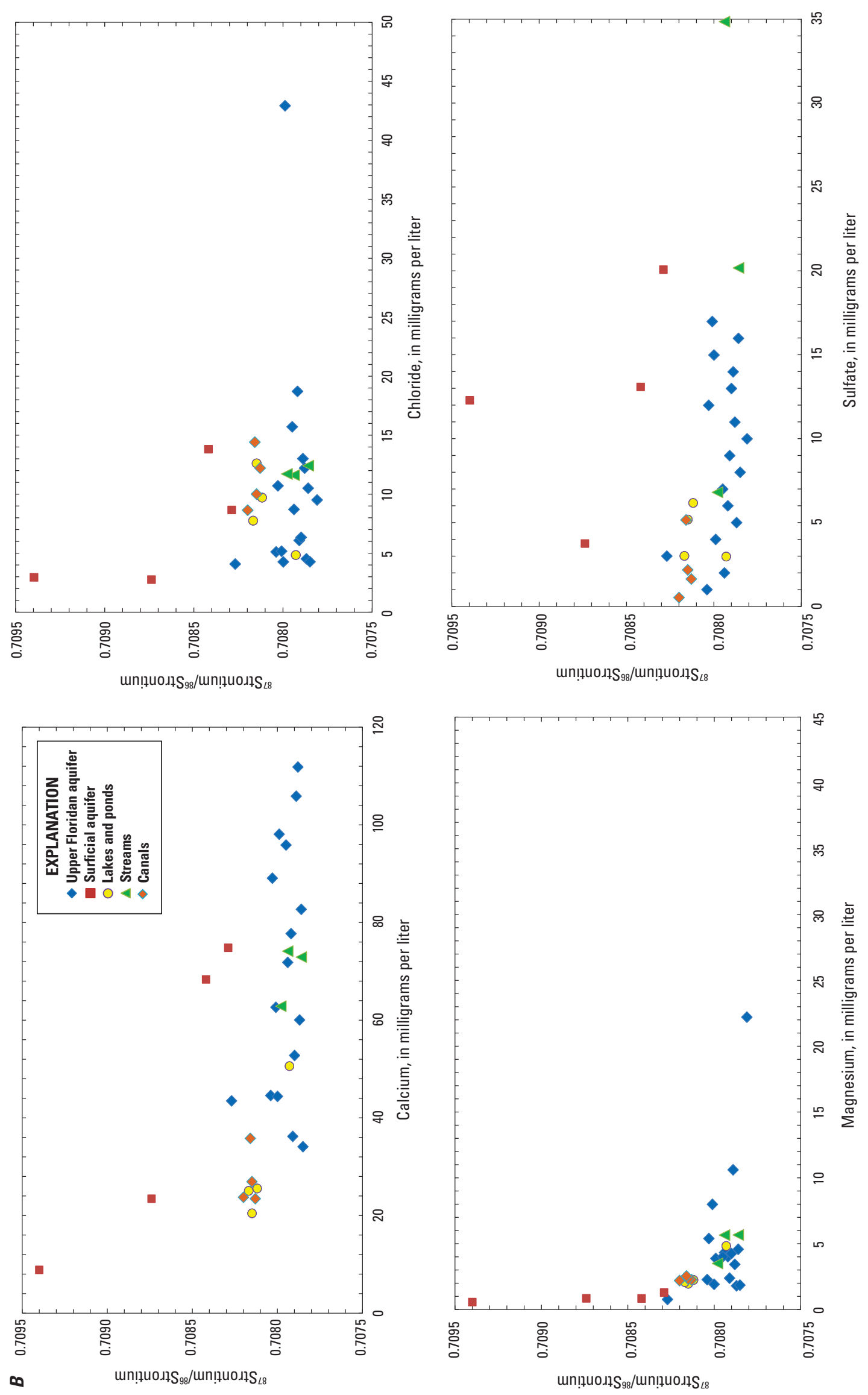

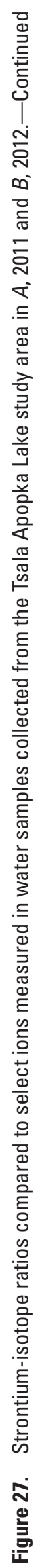


canals (evapoconcentration). Both strontium and chloride are conservative ion species in the environment (Maddox and others, 1992) and tend to increase downstream in a flow system because they are non-reactive with other ions. Ions such as calcium, magnesium, and sulfate tended to have lower concentrations in the lakes and canals than from the river and Upper Floridan aquifer. These ions are all more reactive in the environment compared to strontium and chloride, and likely decrease as they move through the flow system because of chemical and biologic activity in the water. Attardi (1983) determined generally decreasing trends in nutrients, organic carbon, color, and dissolved solids as water flowed north through the three pools. Evapoconcentration likely also occurs in the Withlacoochee River, but the residence time of the water in Tsala Apopka Lake is likely much longer compared to water moving down the river. The river also tends to be more shaded than the lakes, so it receives less solar radiation and, therefore, evaporates less.

The results of the groundwater ${ }^{87} \mathrm{Sr} /{ }^{86} \mathrm{Sr}$ sampling in 2012 were similar to 2011, but most samples contained slightly higher ratios of ${ }^{87} \mathrm{Sr} /{ }^{86} \mathrm{Sr}$ under the wetter conditions, indicating a higher contribution of water from the shallower portions of the Upper Floridan aquifer (Ocala Limestone). All of the samples, except two, fell in the range of ${ }^{87} \mathrm{Sr} /{ }^{86} \mathrm{Sr}$ ratios expected for water that has been in contact with the Upper Floridan aquifer. Samples from TA1 SA well (GW21) and TA2 SA well (GW18) contained ${ }^{87} \mathrm{Sr} /{ }^{86} \mathrm{Sr}$ ratios consistent with that unit. Samples from ROMP 116 SA (GW12) and Flying Eagle SA (GW35) wells both produced water containing ${ }^{87} \mathrm{Sr} /{ }^{86} \mathrm{Sr}$ ratios consistent with the Ocala Limestone. The GW12 well is located on the banks of a canal and likely receives recharged surface water that originated from groundwater sources. It is unclear why the GW35 SA well produces samples with ${ }^{87} \mathrm{Sr} /{ }^{86} \mathrm{Sr}$ ratios consistent with the Upper Floridan aquifer, but it could be caused by karst activity in the area because the well is located at the edge of a small sinkhole pond and hydraulic head data (fig. 19B), which indicates that the site occasionally has slight upward flow potential. All of the samples collected from wells installed in the Upper Floridan aquifer, except one, produced water with ${ }^{87} \mathrm{Sr} /{ }^{86} \mathrm{Sr}$ ratios consistent with either a mixture of groundwater from the Avon Park Formation and Ocala Limestone or the Avon Park Formation only. The sample from the GW5 well, as in 2011, seems to originate from the Ocala Limestone.

During both sampling events, samples from the lakes and canals contained slightly higher ${ }^{87} \mathrm{Sr} /{ }^{86} \mathrm{Sr}$ ratios than samples from the river and Upper Floridan aquifer (fig. 26). The higher ratios in the lakes and canals likely result from mixing with rainwater, runoff, and discharge from the surficial aquifer. Samples collected in 2012 from the lakes and canals tended to have slightly higher ${ }^{87} \mathrm{Sr} /{ }^{86} \mathrm{Sr}$ ratios than in 2011, indicating the lakes and canals contained a higher fraction of water from rainfall, runoff, and the surficial aquifer under the wetter conditions.

\section{Deuterium and 0xygen-18}

Surface-water samples collected in 2011 and 2012 mostly have an enriched $\delta \mathrm{D}$ and $\delta^{18} \mathrm{O}$ signature that is typical of surface water that has undergone kinetic fractionation, most likely from evaporation (fig. 28 and table 3). Lakes in the north of the study area tended to have a more enriched signature than those in the south. The large lakes within Tsala Apopka Lake become shallower from south to north. Large surface areas, combined with shallower depths in the northern lakes, increase the rate of enrichment. Also, surface water flows from south to north in the Tsala Apopka Lake system. During periods when water was flowing through the system, water in the northern part of the study area had more opportunity for enrichment because of longer travel times. Samples from the canal system (fig. 4, table 1, SW8, SW12, SW13, and SW16) tended to have $\delta \mathrm{D}$ and $\delta^{18} \mathrm{O}$ signatures similar to the lakes upstream from the sampling site (SW6, SW10, and SW18). Water from the Withlacoochee River near Pineola (SW20) and Holder (SW2) was slightly enriched because it is a mixture of unenriched discharge from the Upper Floridan aquifer and surface-water sources. The sample from Gum Slough (SW5) in 2011 was unenriched in $\delta \mathrm{D}$ and $\delta^{18} \mathrm{O}$. Site SW5 consisted of water that discharges from several springs and the lack of enrichment likely indicates that the source of the spring flow was internal drainage in the uplands west of the springs. Rainfall infiltrates to the surficial aquifer rapidly in the uplands, which limits opportunities for isotopic enrichment to occur. Likewise, the sample from Jordan Sink Pond (SW1) was also unenriched. Although the pond appeared to be a stagnant pool, the lack of $\delta \mathrm{D}$ and $\delta^{18} \mathrm{O}$ enrichment, combined with the ${ }^{87} \mathrm{Sr} /{ }^{86} \mathrm{Sr}$ source data, indicates that water in the pool readily exchanges with the Upper Floridan aquifer at this site.

The 2011 and $2012 \delta \mathrm{D}$ and $\delta^{18} \mathrm{O}$ data indicate that Upper Floridan aquifer wells located on the western side of Tsala Apopka Lake, but east of the Brooksville Ridge, received recharge from the surface-water system; data from Upper Floridan aquifer wells ROMP 116 UFA (fig. 4, table 1, GW13), TA1 UFA (GW22), Flying Eagle UFA (GW36), and TA5 UFA (GW48) contains an enriched $\delta \mathrm{D}$ and $\delta^{18} \mathrm{O}$ signature consistent with recharge from fractionated surface water. The enriched surface-water signature was only slight in samples from Upper Floridan aquifer wells located farther west along the Brooksville Ridge, such as ROMP 113 UFA (GW25), ROMP 109 UFA (GW54), and CSPR2 UFA (GW41). As the Upper Floridan aquifer groundwater flows westward, the enriched signature was most likely lost through dilution with unenriched groundwater sources, or flow may also have moved deeper into the groundwater flow system at depths beyond where the monitoring wells are finished.

Most of the data from Upper Floridan aquifer samples collected east of the major lakes at Tsala Apopka Lake and west of the Withlacoochee River, including TA2 UFA (GW19), TA6 UFA (GW37), TA4 UFA (GW44), and ROMP 110 UFA 

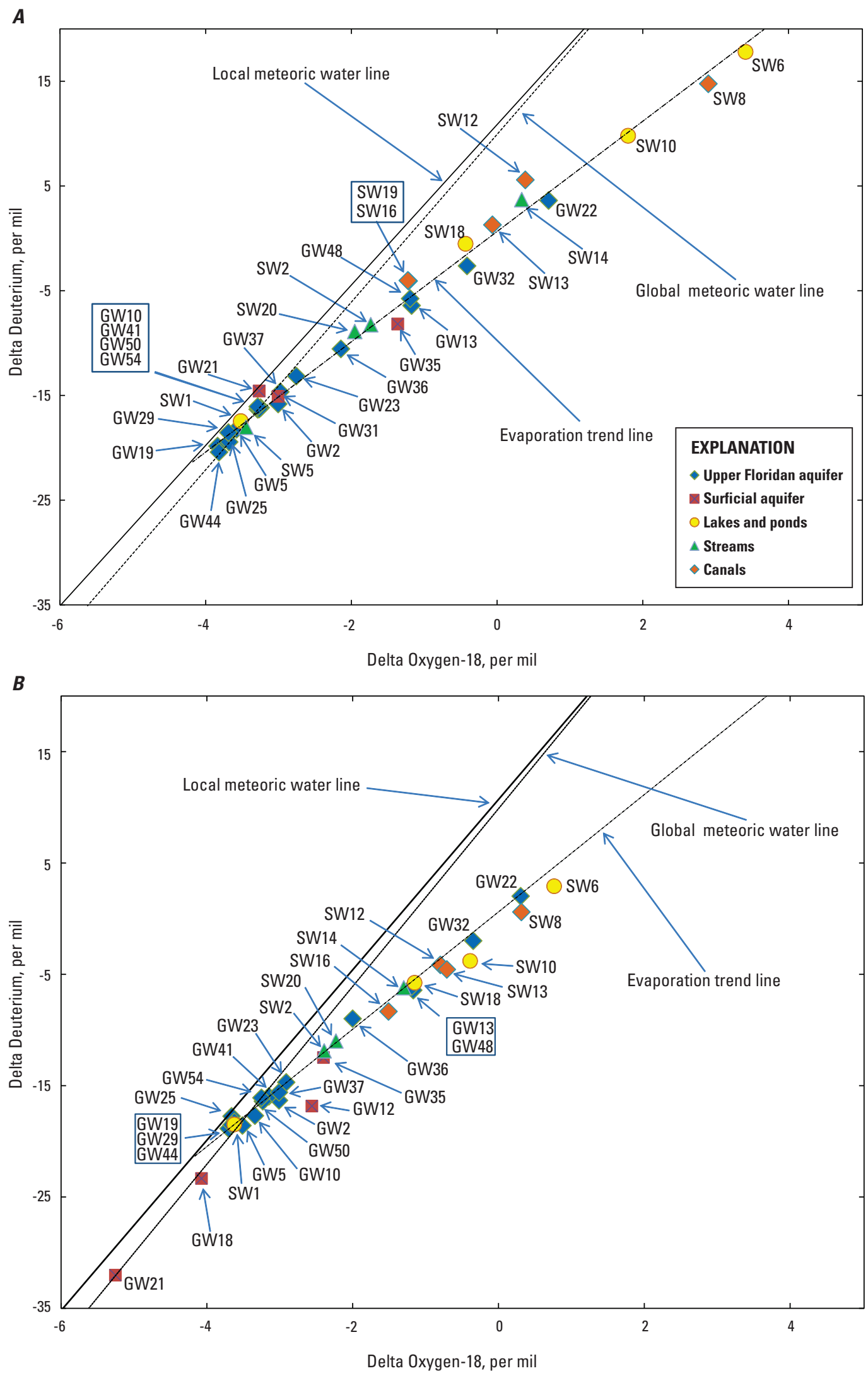

Figure 28. Relation between deuterium and oxygen isotopes in the Tsala Apopka Lake study area in A, December 2011 and B, December 2012 (global meteoric water line from Craig, 1961; local meteoric water line from Sacks, 2002). See table 1 for site descriptions and figure 4 for site locations. 
(GW50) wells, have slight or no $\delta \mathrm{D}$ and $\delta^{18} \mathrm{O}$ enrichment, which likely indicates that the wetlands in the vicinities of these wells do not contribute substantial recharge to the Upper Floridan aquifer. Standing water from wetland areas typically has an enriched $\delta \mathrm{D}$ and $\delta^{18} \mathrm{O}$ signature because of extensive evaporation that occurs under these conditions (Sacks, 2002). Hydraulic head data for wells GW19, GW37, and GW44, and GW50 (figs. 4 and 19) indicate that recharge conditions were unlikely in the area, so it is not surprising that the isotopic data indicated that the wetlands were not contributing recharge to the Upper Floridan aquifer. The wetlands likely have relatively intact confining units beneath them, which enables the wetlands to hold water during the wet season. The $\delta \mathrm{D}$ and $\delta^{18} \mathrm{O}$ sample from Flying Eagle UFA Upper Floridan aquifer well (fig. 4, table 1, GW36), located near the center of the study area, contained enriched water. Although there is evidence of upward flow at GW36, based on hydraulic head and strontium isotope data, the $\delta \mathrm{D}$ and $\delta^{18} \mathrm{O}$ data also indicate periods of recharge. The mixed isotopic signal is likely the result of bidirectional vertical flow at this site depending on the hydrologic conditions.

\section{Age Tracers}

Water samples were collected for the analysis of $\mathrm{SF}_{6}$ and tritium concentrations to aid in the determination of the age of the groundwater at these sites. Groundwater age is defined as the amount of time that has elapsed since a parcel of water was isolated from the atmosphere when it recharged to the groundwater system. Knowledge of the age of a sample can help determine water sources, define the length of an aquifer flowpath, help locate recharge areas, and determine whether water is exchanging between aquifer formations (Cook and Bohlke, 2000). All apparent ages are relative to the year that the sample was collected.

\section{Sulfur Hexafluoride}

On the basis of the apparent age computed from $\mathrm{SF}_{6}$ concentration, all of the Upper Floridan aquifer and surficial aquifer wells that were sampled in the study area produced "young" groundwater. Plummer and Freidman (1999) defined "young" groundwater as groundwater that has recharged in the last 50 years. The age of groundwater was determined for $\mathrm{SF}_{6}$ data assuming piston-flow (that is, a parcel of water that moves through a flow system with no mixing), which is an unlikely scenario in a karst system, where water of different ages may be withdrawn at a well because of secondary porosity features that short-circuit flowpaths. The apparent $\mathrm{SF}_{6}$ ages likely represent a mixture of groundwaters with differing ages and are referred to as apparent or average age to reflect this uncertainty.

The $\mathrm{SF}_{6}$ data collected from the Upper Floridan aquifer wells sampled in 2011 recharged, on average, in about 1990 (table 5) and ranged from 16 to 36 years in age, with a mean apparent age of 22 years and a median apparent age of 21 years. In 2012, the $\mathrm{SF}_{6}$ results were similar to those collected in 2011. On average, the Upper Floridan aquifer wells produced water recharged in about 1992. The 2012 Upper Floridan aquifer samples ranged in apparent age from 13 to 33 years with a mean and median age of 21 years.

The $\mathrm{SF}_{6}$ age for data collected from wells screened in the surficial aquifer was 8 and 13 years in 2011 (there were only two samples from the surficial aquifer in 2011) and ranged from 5 to 11 years in 2012. In 2011, the mean apparent age was 10 years, whereas in 2012 the mean and median were 8 and 9 years, respectively. Flying Eagle SA (GW35) well was the only surficial aquifer site that was successfully sampled in both 2011 and 2012 and it produced water of similar apparent ages, 8 and 10 years, in both sampling events (table 5).

The variability in groundwater ages in the study area does not seem to be spatially dependent, because in no part of the study area does the apparent age of groundwater in the Upper Floridan aquifer seem considerably older or younger. The variation in the age of the groundwater probably relates more to the depth of the wells than the spatial location within the study area. Aquifers with confining conditions typically show an increase in the apparent age of groundwater as it moves along a flowpath, but in the study area groundwater was relatively uniform in apparent age, which is an indication that infiltration occurred at multiple points in the study area. This theory supports the idea that the intermediate confining unit is highly dissected or laterally discontinuous in the Tsala Apopka Lake area. Age data collected from paired surficial aquifer and Upper Floridan aquifer wells were limited, but the difference in apparent age for the paired samples at each site varied from 16 to 19 years, which is an indication of the time that is required for the average parcel of water to recharge from the surficial aquifer to the Upper Floridan aquifer in the study area. The age difference is also an indication that upward flow from the Upper Floridan aquifer is not occurring at these sites and supports the idea that the pools are primarily recharge areas.

\section{Tritium}

Tritium concentration data were used to verify $\mathrm{SF}_{6}$ apparent ages. When there is strong correlation in the apparent ages generated by the tritium and $\mathrm{SF}_{6}$ dating methods there is a greater certainty in the $\mathrm{SF}_{6}$ age. The $\mathrm{SF}_{6}$ molecule is typically inert in the environment, but under rare conditions, such as when a site is contaminated with a natural source of $\mathrm{SF}_{6}$ or when microbial degradation occurs, the $\mathrm{SF}_{6}$ concentration can be altered leading to errors in age estimations (Busenberg and Plummer, 2000).

The apparent ages generated by the two dating methods (table 5) generally were similar for the Upper Floridan aquifer and differed for the surficial aquifer. Mean difference in apparent recharge age $\left(\mathrm{SF}_{6}\right.$ apparent recharge age minus tritium apparent recharge age) for the Upper Floridan aquifer and surficial aquifer were -0.5 and -9.0 years, respectively, 


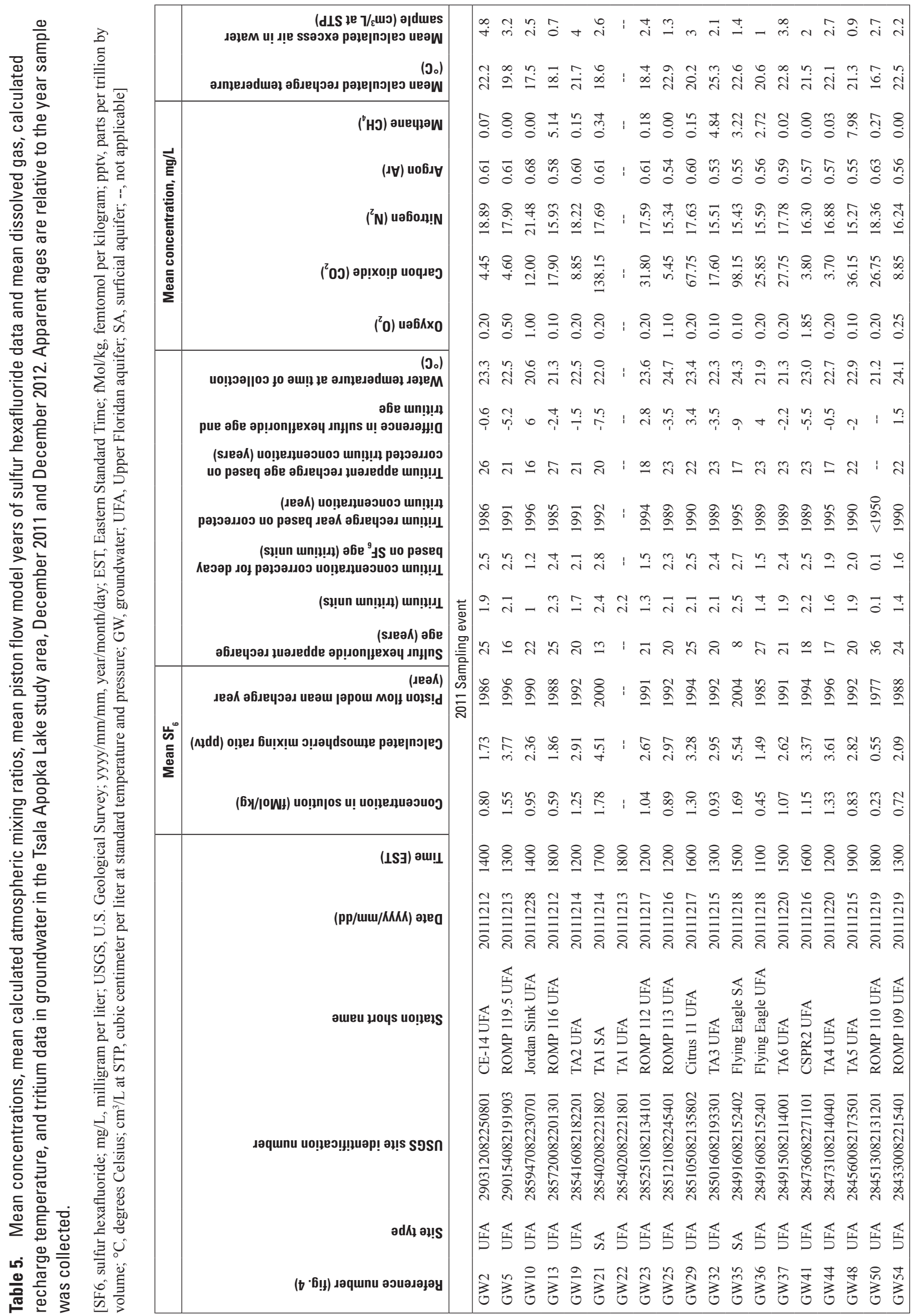




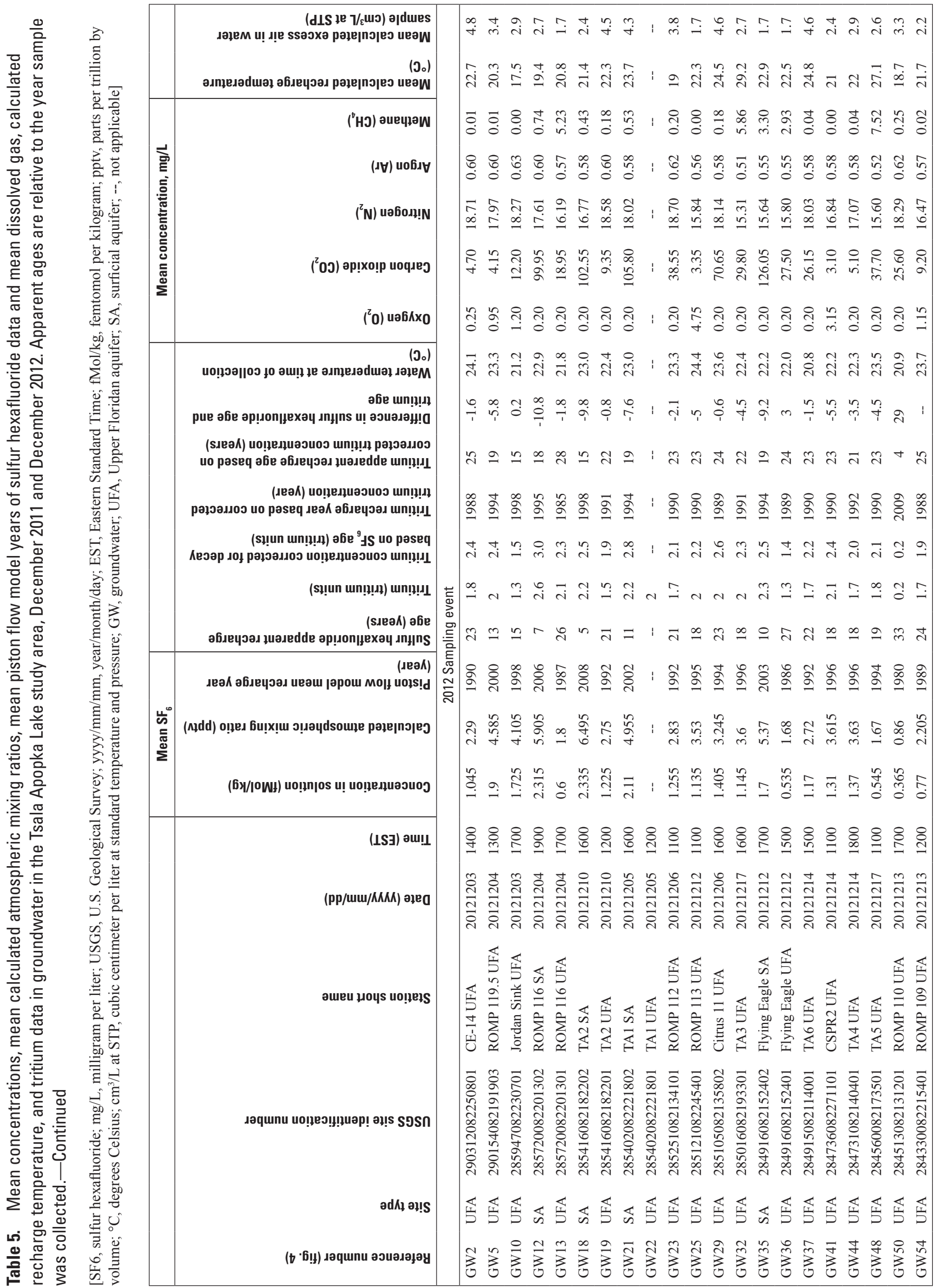


with the surficial aquifer apparent-age difference significantly different from zero based on paired t-tests at 0.05 probability of type-I error and 6 age differences. The differences in calculated apparent ages for data collected from the surficial aquifer might be attributable to differences in how $\mathrm{SF}_{6}$ and tritium are affected by dispersion (Hinkle and others, 2010). Tritium apparent recharge age can sometimes be biased old because of long residence times in wet soils or the unsaturated zone before reaching the water table. Similarly, dissolved gases, such as $\mathrm{SF}_{6}$, can be affected by diffusion, but generally to a lesser degree than tritium from dispersion. Disparities in groundwater ages generated by different methods can also be an indication of mixtures of water of different ages, which seems an unlikely scenario for the water from the surficial aquifer considering the shallow depth of the wells; however, this scenario does likely explain the discrepancy in apparent recharge ages from Upper Floridan aquifer well ROMP 110 UFA (fig. 4, tables 1 and 5, GW50). The $\mathrm{SF}_{6}$ ages in 2011 and 2012, respectively, were 34 and 32 years. The tritium apparent recharge age could not be calculated for the 2011 sample because the tritium concentration was less than modern atmospheric concentration. The apparent recharge age for the sample collected in 2012 was 4 years. The very low concentrations of tritium in these samples likely indicate that a fraction of the water contained in the samples pre-dates nuclear testing and is greater than 60 years of age. This well was the only well in the study area that produced samples that seem to contain a significant fraction of water that recharged prior to atomic testing. If GW50 is disregarded, the mean difference in apparent age for Upper Floridan aquifer samples is -1.5 years and is significantly different from zero.

\section{Water Budget}

A water budget defines the balance of inflows and outflows to and from a control volume and is a useful tool for understanding surface-water/groundwater interactions and the sustainability of the hydrologic system (Healy and others, 2007). The water-budget analysis as presented in this report includes separate annual budgets for control volumes associated with the Floral City, Inverness, and Hernando Pools, and for the composite three-pool area for 2004-12. The waterbudget analysis also describes the interaction of the Withlacoochee River with Tsala Apopka Lake and the effect this interaction has on the surface-water and groundwater system.

The major components of the water budget include surface-water (lakes and wetlands) and groundwater storage, rainfall, actual evapotranspiration (AET), and surface-water inflows and outflows. The measured components were applied to equation 6 to estimate $G_{\text {net }}$.

\section{Rainfall}

Rainfall, computed on the basis of NEXRAD data, was the dominant factor in the water budget of the Tsala Apopka Lake system for 2004-12 (tables 6-9). The driest year in the Floral City and Inverness Pools was 2006, with total rainfall of 42 and 43 in., respectively, whereas in the Hernando Pool, the driest year was 2011, with 42 in. of rainfall (tables 6-8). Total rainfall in 2006 for the Hernando Pool was 44 in. The composite three-pool area was driest in 2006 with 43 in. of rainfall (table 9). The wettest year for all three pools was 2005, with

Table 6. Yearly water-budget terms, computed net groundwater flow, and estimated uncertainty or error associated with the computed net groundwater flow for the Floral City Pool, 2004-12.

[SW, surface water; GW, groundwater; NEXRAD, Next-Generation Radar; AET, actual evapotranspiration; in/yr, inches per year; $\mathrm{G}_{\text {net }}$, net groundwater flow; $\mathrm{eG}_{\text {net, }}, \mathrm{G}_{\text {net }}$ error]

\begin{tabular}{|c|c|c|c|c|c|c|c|}
\hline \multicolumn{8}{|c|}{ Floral City Pool } \\
\hline Date & $\begin{array}{c}\text { Change in } \\
\text { storage } \\
\text { (SW and GW), } \\
\text { in/yr }\end{array}$ & $\begin{array}{c}\text { NEXRAD } \\
\text { rainfall, } \\
\text { in/yr }\end{array}$ & $\begin{array}{c}\text { Pool evapo- } \\
\text { transpiration } \\
\text { (AET), } \\
\text { in/yr }\end{array}$ & $\begin{array}{c}\text { Total surface- } \\
\text { water inflow, } \\
\text { in } / y r\end{array}$ & $\begin{array}{c}\text { Total surface- } \\
\text { water outflow, } \\
\text { in/yr }\end{array}$ & $\begin{array}{l}\mathbf{G}_{\text {net' }} \\
\text { in/yr }\end{array}$ & $\begin{array}{c}\mathbf{e G}_{\text {net' }^{\prime}} \\
\text { maximum error, } \text { in/yr, plus or } \\
\text { minus }\end{array}$ \\
\hline 2004 & 5 & 56 & 46 & 18 & 14 & -9 & 6 \\
\hline 2005 & -1 & 59 & 48 & 3 & 2 & -13 & 5 \\
\hline 2006 & -16 & 42 & 54 & 1 & 0 & -6 & 4 \\
\hline 2007 & 6 & 52 & 52 & 6 & 0 & 0 & 3 \\
\hline 2008 & -2 & 47 & 50 & 14 & 15 & 2 & 4 \\
\hline 2009 & 1 & 52 & 51 & 25 & 17 & -9 & 5 \\
\hline 2010 & -5 & 49 & 50 & 23 & 21 & -5 & 5 \\
\hline 2011 & 3 & 52 & 51 & 15 & 12 & -2 & 4 \\
\hline 2012 & 10 & 56 & 48 & 55 & 30 & -24 & 5 \\
\hline $\begin{array}{l}\text { Average } \\
2004-12\end{array}$ & 0 & 52 & 50 & 18 & 12 & -7 & 4 \\
\hline
\end{tabular}


Table 7. Yearly water-budget terms, computed net groundwater flow, and estimated uncertainty or error associated with the computed net groundwater flow for the Inverness Pool, 2004-12.

[SW, surface water; GW, groundwater; NEXRAD, Next-Generation Radar; AET, actual evapotranspiration; in/yr, inches per year; $\mathrm{G}_{\text {net }}$, net groundwater flow; $\mathrm{eG}_{\mathrm{net}}, \mathrm{G}_{\text {net }}$ error]

\begin{tabular}{|c|c|c|c|c|c|c|c|}
\hline \multicolumn{8}{|c|}{ Inverness Pool } \\
\hline Date & $\begin{array}{c}\text { Change in } \\
\text { storage } \\
\text { (SW and GW), } \\
\text { in/yr }\end{array}$ & $\begin{array}{c}\text { NEXRAD } \\
\text { rainfall, } \\
\text { in/yr }\end{array}$ & $\begin{array}{c}\text { Pool evapo- } \\
\text { transpiration } \\
\text { (AET), } \\
\text { in/yr }\end{array}$ & $\begin{array}{c}\text { Total surface- } \\
\text { water inflow, } \\
\text { in/yr }\end{array}$ & $\begin{array}{c}\text { Total surface- } \\
\text { water outflow, } \\
\text { in/yr }\end{array}$ & $\begin{array}{c}\mathbf{G}_{\text {net' }} \\
\text { in/yr }\end{array}$ & $\begin{array}{c}\mathbf{e G}_{\text {net' }} \\
\text { maximum error, } \\
\text { in/yr, plus or } \\
\text { minus }\end{array}$ \\
\hline 2004 & 6 & 59 & 46 & 17 & 8 & -16 & 5 \\
\hline 2005 & -2 & 60 & 48 & 2 & 6 & -10 & 4 \\
\hline 2007 & -2 & 46 & 51 & 0 & 0 & 3 & 5 \\
\hline 2008 & 2 & 48 & 50 & 17 & 0 & -13 & 5 \\
\hline 2009 & 4 & 48 & 50 & 20 & 13 & -1 & 5 \\
\hline 2010 & -1 & 49 & 50 & 25 & 7 & -19 & 4 \\
\hline 2011 & -2 & 49 & 51 & 13 & 5 & -8 & 5 \\
\hline
\end{tabular}

Table 8. Yearly water-budget terms, computed net groundwater flow, and estimated uncertainty or error associated with the computed net groundwater flow for the Hernando Pool, 2004-12.

[SW, surface water; GW, groundwater; NEXRAD, Next-Generation Radar; AET, actual evapotranspiration; in/yr, inches per year; $\mathrm{G}_{\text {net }}$, net groundwater flow; $\mathrm{eG}_{\text {net }}, \mathrm{G}_{\text {net }}$ error]

\begin{tabular}{|c|c|c|c|c|c|c|c|}
\hline \multicolumn{8}{|c|}{ Hernando Pool } \\
\hline Date & $\begin{array}{c}\text { Change in } \\
\text { storage } \\
\text { (SW and GW), } \\
\text { in/yr }\end{array}$ & $\begin{array}{l}\text { NEXRAD } \\
\text { rainfall, } \\
\text { in/yr }\end{array}$ & $\begin{array}{c}\text { Pool evapo- } \\
\text { transpiration } \\
\text { (AET), } \\
\text { in/yr }\end{array}$ & $\begin{array}{c}\text { Total surface- } \\
\text { water inflow, } \\
\text { in/yr }\end{array}$ & $\begin{array}{l}\text { Total surface- } \\
\text { water outflow, } \\
\text { in/yr }\end{array}$ & $\begin{array}{c}\mathbf{G}_{\text {net' }} \\
\text { in/yr }\end{array}$ & $\begin{array}{c}\mathbf{e G}_{\text {net' }^{\prime}} \\
\text { maximum error, } \\
\text { in/yr, plus or } \\
\text { minus }\end{array}$ \\
\hline 2004 & 7 & 58 & 47 & 7 & 13 & 1 & 5 \\
\hline 2005 & -2 & 61 & 49 & 5 & 13 & -7 & 5 \\
\hline 2007 & -1 & 47 & 53 & 0 & 0 & 5 & 3 \\
\hline 2008 & -1 & 55 & 51 & 0 & 0 & -4 & 3 \\
\hline 2009 & 4 & 53 & 52 & 12 & 0 & -9 & 3 \\
\hline 2010 & 1 & 53 & 51 & 6 & 0 & -7 & 4 \\
\hline
\end{tabular}


Table 9. Yearly water-budget terms, computed net groundwater flow, and estimated uncertainty or error associated with the computed net groundwater flow for the composite three-pool area, 2004-12.

[SW, surface water; GW, groundwater; NEXRAD, Next-Generation Radar; AET, actual evapotranspiration; in/yr, inch per year; $\mathrm{G}_{\text {net }}$, net groundwater flow; $\mathrm{eG}_{\text {net, }}, \mathrm{G}_{\text {net }}$ error]

\begin{tabular}{|c|c|c|c|c|c|c|c|}
\hline \multicolumn{8}{|c|}{ Composite of the three-pool area } \\
\hline Date & $\begin{array}{c}\text { Change in } \\
\text { storage } \\
\text { (SW and GW), } \\
\text { in/yr }\end{array}$ & $\begin{array}{l}\text { NEXRAD } \\
\text { rainfall, } \\
\text { in/yr }\end{array}$ & $\begin{array}{l}\text { Pool evapo- } \\
\text { transpiration } \\
\text { (AET), } \\
\text { in/yr }\end{array}$ & $\begin{array}{c}\text { Total surface- } \\
\text { water inflow, } \\
\text { in/yr }\end{array}$ & $\begin{array}{c}\text { Total surface- } \\
\text { water outflow, } \\
\text { in/yr }\end{array}$ & $\begin{array}{l}G_{\text {net' }} \\
\text { in/yr }\end{array}$ & $\begin{array}{c}\mathbf{e G}_{\text {net' }} \\
\text { maximum error } \\
\text { in/yr, plus or } \\
\text { minus }\end{array}$ \\
\hline 2004 & 6 & 57 & 46 & 7 & 4 & -8 & 5 \\
\hline 2005 & -2 & 60 & 48 & 1 & 4 & -10 & 5 \\
\hline 2006 & -15 & 43 & 54 & 0 & 0 & -4 & 4 \\
\hline 2007 & 1 & 48 & 52 & 2 & 0 & 3 & 3 \\
\hline 2008 & -1 & 50 & 51 & 5 & 0 & -5 & 4 \\
\hline 2009 & 3 & 51 & 51 & 9 & 0 & -6 & 4 \\
\hline 2010 & -2 & 50 & 50 & 8 & 0 & -10 & 4 \\
\hline 2011 & -1 & 48 & 51 & 6 & 0 & -4 & 4 \\
\hline 2012 & 12 & 58 & 48 & 20 & 0 & -17 & 4 \\
\hline $\begin{array}{l}\text { Average } \\
2004-12\end{array}$ & 0 & 52 & 50 & 6 & 1 & -7 & 4 \\
\hline
\end{tabular}

59, 60, and 61 in. in the Floral City, Inverness, and Hernando Pools, respectively. The Hernando Pool also received 61 in. in 2012.

Total annual and monthly rainfall at times varied considerably from pool to pool during 2004-12 (figs. 29 and 30, tables 6-8). The most extreme instance occurred in 2011, when annual rainfall for the Floral City Pool and Hernando Pool differed by 10 in. of rainfall (fig. 29), with the largest differences in the summer months (fig. 30B). Annual rainfall for the Floral City Pool and Hernando Pool was 52 in. and 42 in., respectively. In 2008, Hernando Pool received 55 in. of annual rainfall, whereas Floral City Pool received only 47 in., which was an 8-in. difference (figs. 29 and 30A). Neighboring pools varied by as much as 7 in. of rainfall annually, such as Inverness and Hernando Pools in 2008 and 2011 (figs. 29 and 30).

There were several major rainfall events in the Tsala Apopka area during 2004-12 (fig. 31). In August-September 2004, Hurricanes Charley, Frances, and Jeanne made landfall in Florida and resulted in nearly 24 in. of rainfall for the 2-month period. About 17 in. fell in September alone, which was the single wettest month of the study period. Other notable rainfall events included Tropical Storm Fay in August 2008, which resulted in about 13 in. of rainfall, and Tropical Storm Debby in June 2012, with rainfall of about 16 in.

\section{Evapotranspiration}

Actual evapotranspiration was computed as a function of gridded estimates of RET and monthly land-cover coefficients, as discussed in the "Methods" section. Six sets of monthly land-cover coefficients were calculated based on the major land-cover types in the study area (forest, grass, wetland, lake, ridge, and urban; fig. 32, table 10). The derived landcover coefficient ratios ranged from 0.45 for ridge in January to 1.18 for lake in August. Note that AET from lakes can exceed RET. Land-cover coefficients were weighted based on the distribution of land-cover types within each RET pixel (table 11). Note that acreages of land covers for each pool vary slightly from actual acreages for each pool because they are based on the NEXRAD grid, which does not precisely align with the actual pool perimeter (fig. 17).

Lake was the most common land cover in each of the three pools, varying from 36 to 53 percent of the total pool area (table 11), whereas wetland was the second most common at 17 to 33 percent. Lake and wetland together accounted for 69, 68, and 70 percent of the land area in the Floral City, Inverness, and Hernando Pools, respectively. Much of the rest of the land area in the pools was classified either as urban or grass (fig. 32 and table 11). Forest and ridge accounted for no more than 3 percent of the land cover in any of the pools.

Evapotranspiration was the most consistent of the annual water-budget terms and all three pools had similar trends (fig. 33). The Hernando Pool had slightly higher annual AET rates (fig. 33, table 9) than the other pools because it has the largest lake area of the three pools, about 53 percent of the pool area compared to 36 and 38 percent for the Floral City and Inverness Pools, respectively, and monthly land-cover coefficients are higher for lakes than other land-cover types (table 11). Annual AET rates for the three pools (fig. 33 and 


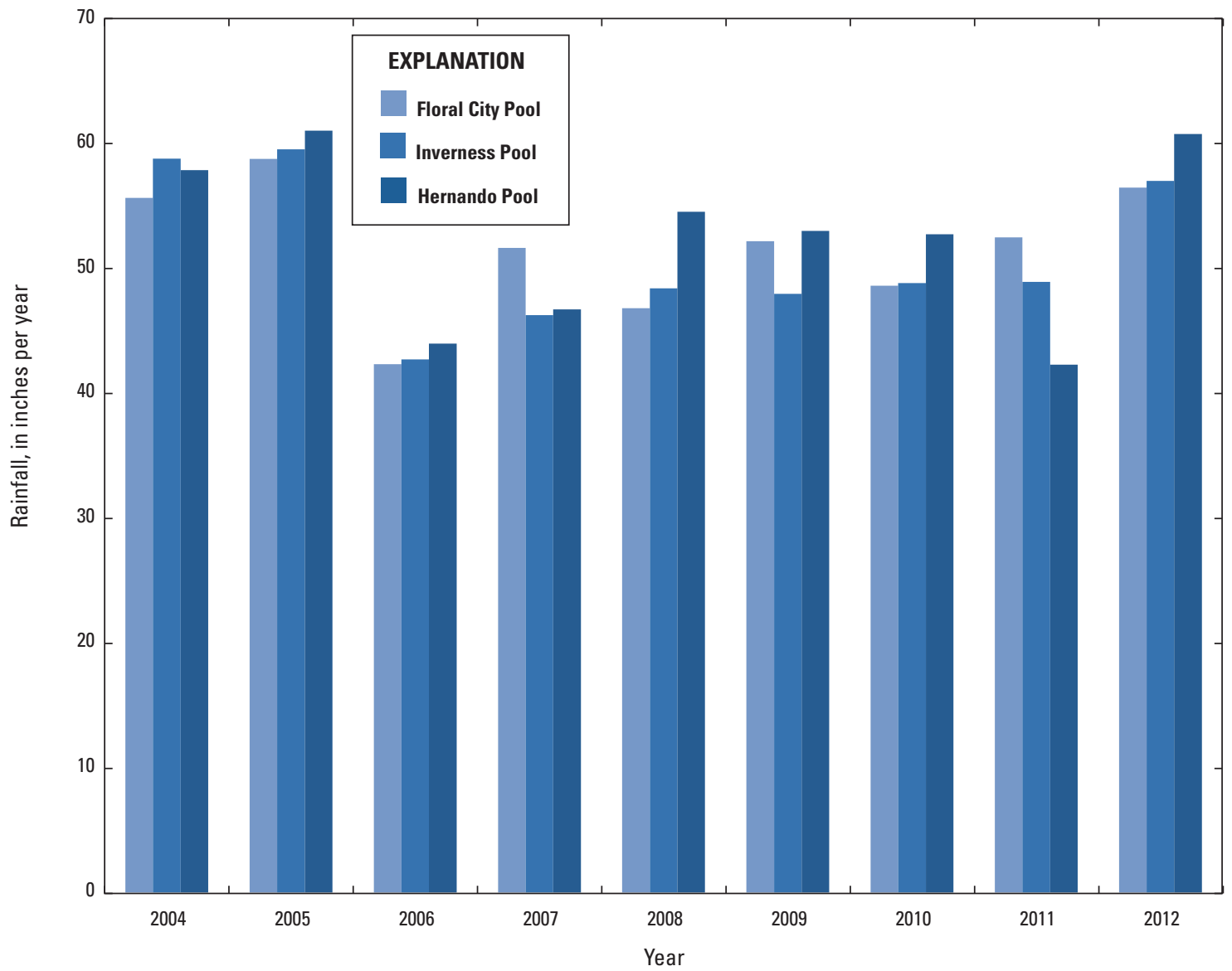

Figure 29. Comparison of annual Next-Generation Radar (NEXRAD) rainfall for the Floral City Pool, Inverness Pool, and Hernando Pool, 2004-12 (Southwest Florida Water Management District, 2017d).

table 9) were lowest in 2004 (46 in/yr) and highest in 2006 (54 in/yr). Lower AET rates occurred during years with high rainfall amounts, whereas high AET rates occurred during years with low rainfall. Wet years generally have greater cloud cover and, therefore, lower incident solar radiation, which results in lower AET rates (Mecikalski and others, 2011). In some years, based on the composite three-pool area, AET rates exceeded precipitation rates, such as in 2006, 2007, 2008, and 2011 (table 9).

\section{Surface-Water and Groundwater Storage}

Lake stage (fig. 34A) and groundwater levels at the ROMP 110 SA well (fig. 34B) were used to compute the change in surface-water and groundwater storage for each pool and for the composite three-pool area. Lake stage and groundwater levels showed similar responses to rainfall in the three pools (figs. 34A-C). Groundwater levels and lake stages tended to rise rapidly following heavy rainfall with little or no lag in groundwater response to events.
Histograms of lake-stage data were used to compare and contrast the hydrologic conditions of the three pools from 2004 to 2012. During the water-budget period, the median stage for Floral City Pool (fig. 35A) was $38.55 \mathrm{ft}$. The minimum lake stage of $33.38 \mathrm{ft}$ was on July 10, 2007, and the maximum was $41.82 \mathrm{ft}$ on September 27, 2004. Floral City Pool had the greatest range in stages at $8.44 \mathrm{ft}$. In the Inverness Pool (fig. 35B), the median lake stage was $36.60 \mathrm{ft}$. The minimum stage was $32.68 \mathrm{ft}$ on July 2, 2007, and the maximum was $40.05 \mathrm{ft}$ on October 6, 2004. Range of stage in the Inverness Pool was $7.37 \mathrm{ft}$. In the Hernando Pool (fig. 35C), the minimum and maximum stages were $31.20 \mathrm{ft}$ and $39.00 \mathrm{ft}$ on May 28, 2012, and October 12, 2004, respectively. The median stage was $35.39 \mathrm{ft}$ and the range of stage for the Hernando Pool was $7.80 \mathrm{ft}$.

Analysis of the composite surface-water and groundwater storage data indicated that the largest annual storage decline was -15 in. in 2006 (table 9). This decline was associated with the lowest amount of annual rainfall (NEXRAD) for the water-budget period (43 in.) and the highest annual 
A

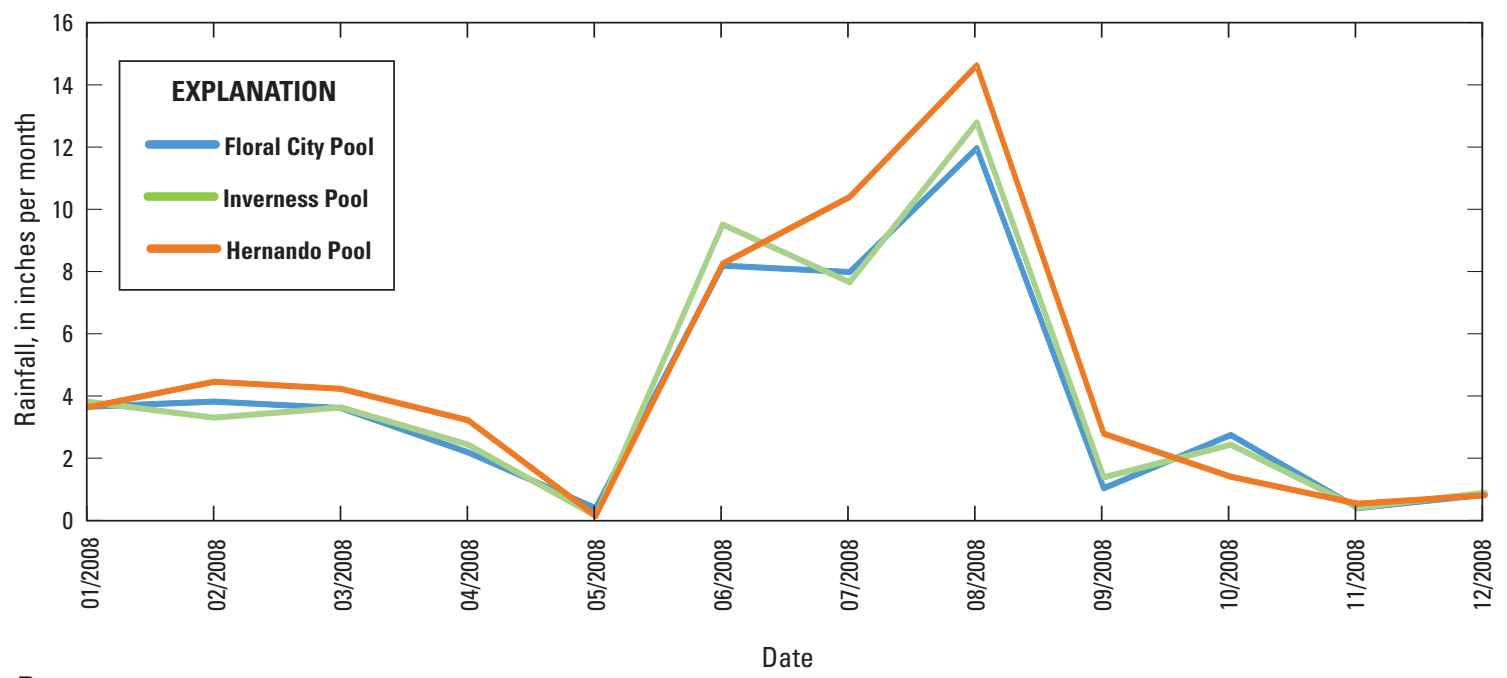

$\boldsymbol{B}$

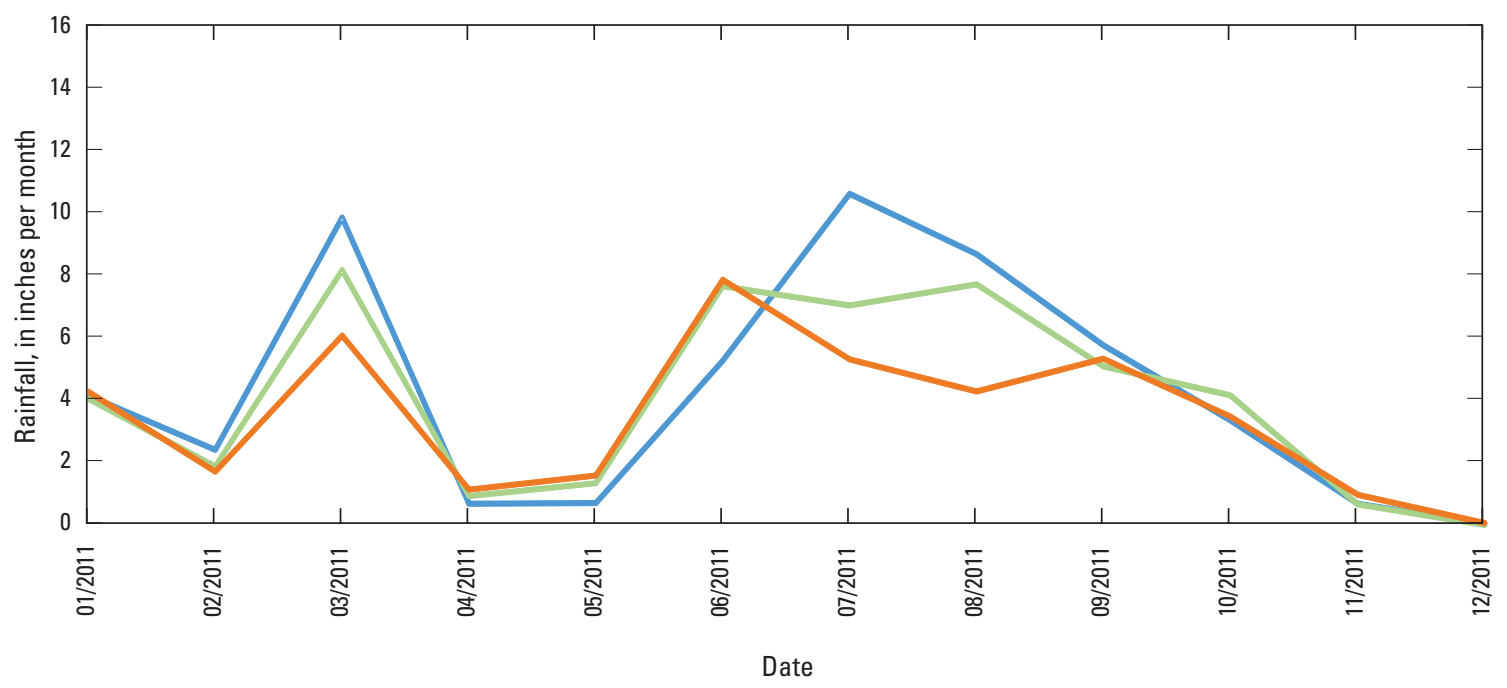

Figure 30. Monthly total of Next-Generation Radar (NEXRAD) rainfall in the Floral City Pool, Inverness Pool, and Hernando Pool in A, 2008 and B, 2011 (Southwest Florida Water Management District, 2017d).

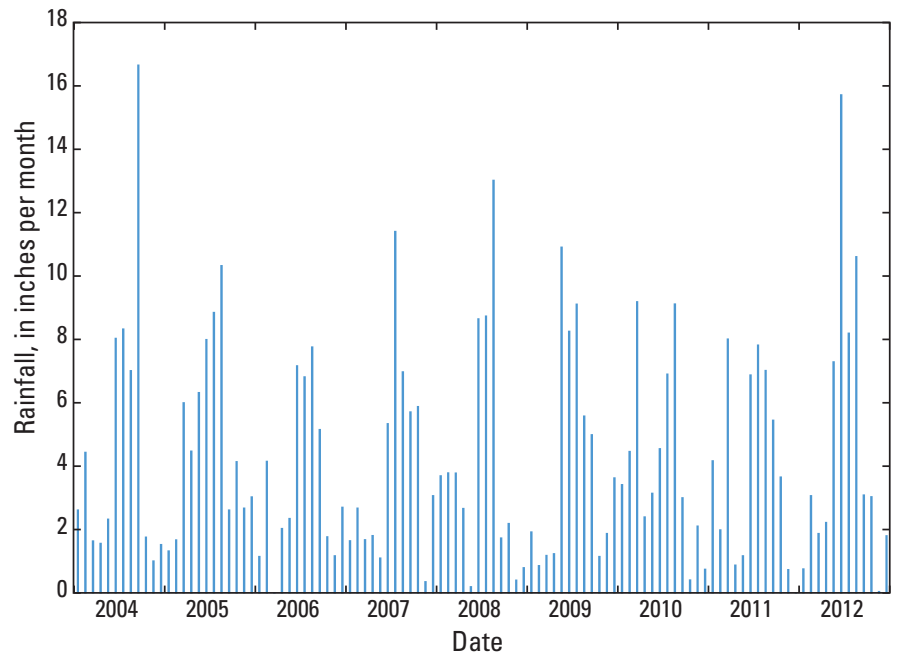

Figure 31. Next-Generation Radar (NEXRAD) monthly rainfall in the composite three-pool area, 2004-12 (Southwest Florida Water Management District, 2017d). 


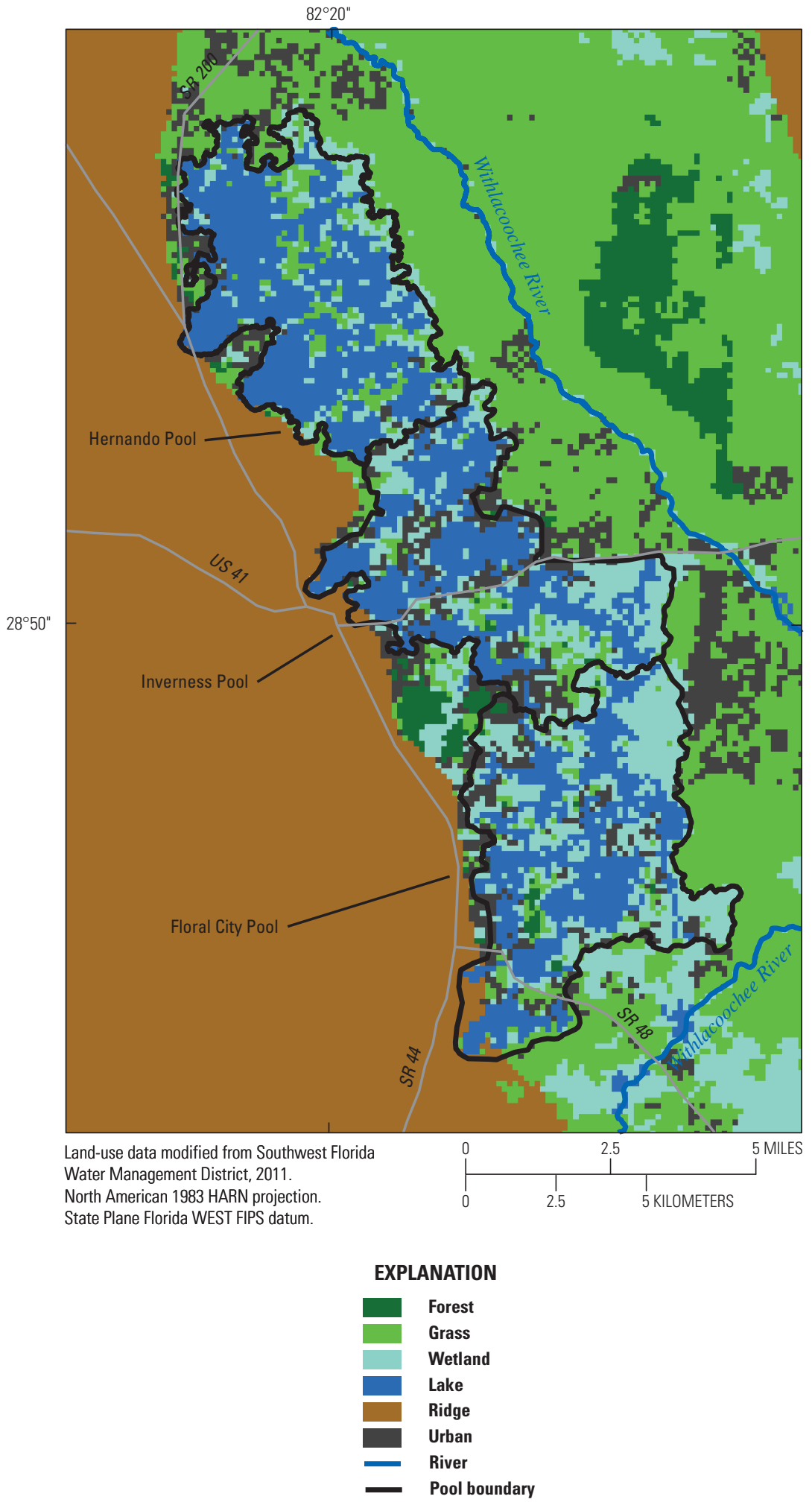

Figure 32. Generalized land cover in the Floral City Pool, Inverness Pool, and Hernando Pool by Next-Generation Radar (NEXRAD) grid cell (Southwest Florida Water Management District, 2017e). See figure 17 for grid cell identification numbers and table 10 for the percentage and acreage of land cover by grid cell. 


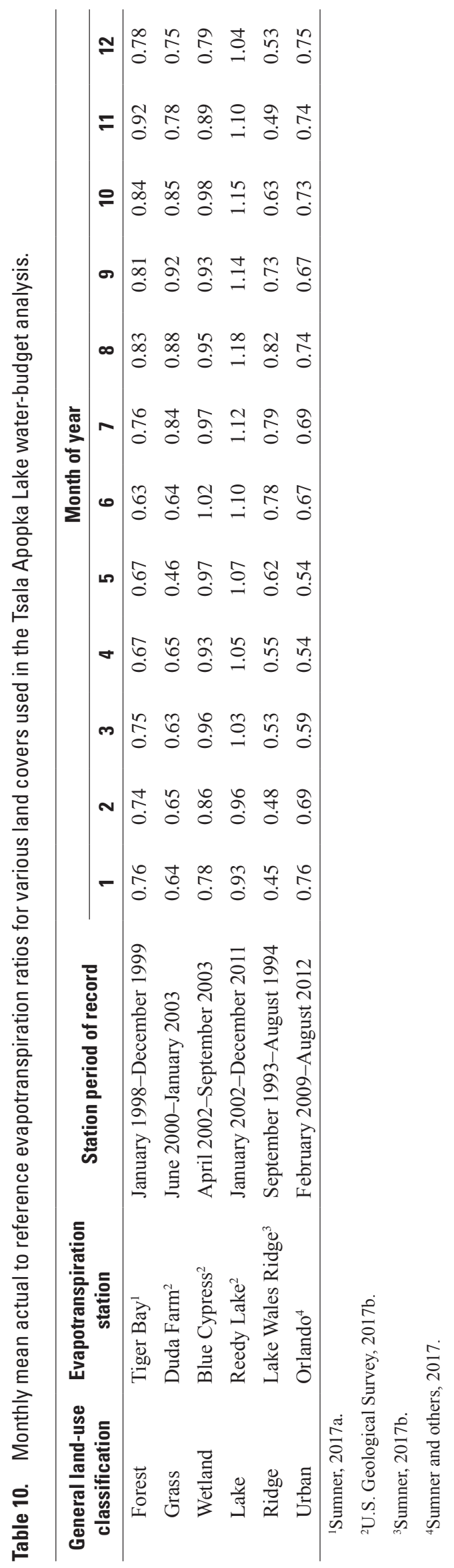


Table 11. Land-cover types, percentage of land by type, and acreage of land by type in each Next-Generation Radar (NEXRAD) grid cell in the Floral City Pool, Inverness Pool, and Hernando Pool, 2011.

\begin{tabular}{|c|c|c|c|c|c|c|c|c|c|c|c|c|}
\hline \multicolumn{13}{|c|}{ Floral City Pool } \\
\hline \multicolumn{7}{|c|}{ Percentage of land type in each grid cell } & \multicolumn{6}{|c|}{ Acreage of land type in each grid cell } \\
\hline $\begin{array}{l}\text { NEXRAD } \\
\text { Grid Cell }\end{array}$ & FOREST & GRASS & WETLAND & LAKE & RIDGE & URBAN & FOREST & GRASS & WETLAND & LAKE & RIDGE & URBAN \\
\hline 118824 & 1.3 & 42.1 & 20.1 & 20.1 & 0.0 & 16.4 & 12 & 417 & 199 & 199 & 0 & 162 \\
\hline 119297 & 7.5 & 6.3 & 10.0 & 30.6 & 11.3 & 34.4 & 74 & 62 & 99 & 303 & 111 & 340 \\
\hline 119298 & 6.3 & 8.1 & 30.6 & 49.4 & 0.0 & 5.6 & 62 & 80 & 303 & 488 & 0 & 56 \\
\hline 119300 & 0.0 & 18.6 & 62.7 & 6.8 & 0.0 & 11.8 & 0 & 184 & 620 & 68 & 0 & 117 \\
\hline 119771 & 2.5 & 9.4 & 23.8 & 44.4 & 0.0 & 20.0 & 25 & 93 & 235 & 439 & 0 & 198 \\
\hline 119772 & 0.0 & 8.1 & 36.3 & 50.6 & 0.0 & 5.0 & 0 & 80 & 358 & 500 & 0 & 49 \\
\hline 119773 & 1.3 & 3.1 & 31.9 & 45.6 & 0.0 & 18.1 & 12 & 31 & 315 & 451 & 0 & 179 \\
\hline 120245 & 0.6 & 5.6 & 38.8 & 21.3 & 0.0 & 33.8 & 6 & 56 & 383 & 210 & 0 & 334 \\
\hline 120246 & 0.6 & 6.9 & 25.6 & 61.9 & 0.0 & 5.0 & 6 & 68 & 253 & 612 & 0 & 49 \\
\hline \multicolumn{7}{|l|}{ Total acres } & 353 & 1,544 & 4,514 & 4,962 & 289 & 2,176 \\
\hline \multicolumn{7}{|c|}{ Percentage of total pool area } & 2.6 & 11.2 & 32.6 & 35.9 & 2.1 & 15.7 \\
\hline \multicolumn{13}{|c|}{ Inverness Pool } \\
\hline \multicolumn{7}{|c|}{ Percentage of land type in each grid cell } & \multicolumn{6}{|c|}{ Acreage of land type in each grid cell } \\
\hline $\begin{array}{l}\text { NEXRAD } \\
\text { Grid Cell }\end{array}$ & FOREST & GRASS & WETLAND & LAKE & RIDGE & URBAN & FOREST & GRASS & WETLAND & LAKE & RIDGE & URBAN \\
\hline 120720 & 0.6 & 20.0 & 38.8 & 14.4 & 0.0 & 26.3 & 6 & 198 & 383 & 142 & 0 & 259 \\
\hline 121192 & 2.5 & 14.9 & 23.0 & 32.3 & 0.0 & 27.3 & 25 & 147 & 227 & 319 & 0 & 270 \\
\hline 121193 & 3.1 & 13.8 & 20.6 & 49.4 & 0.0 & 13.1 & 31 & 136 & 204 & 488 & 0 & 130 \\
\hline 121194 & 2.5 & 23.1 & 42.5 & 25.0 & 0.0 & 6.9 & 25 & 229 & 420 & 247 & 0 & 68 \\
\hline 121195 & 0.0 & 12.6 & 45.9 & 40.3 & 0.0 & 1.3 & 0 & 124 & 454 & 398 & 0 & 12 \\
\hline Percentage & of total poc & 1 area & & & & & 0.9 & 12.3 & 29.8 & 38.3 & 0.6 & 18.2 \\
\hline \multicolumn{13}{|c|}{ Hernando Pool } \\
\hline \multicolumn{7}{|c|}{ Percentage of land type in each grid cell } & \multicolumn{6}{|c|}{ Acreage of land type in each grid cell } \\
\hline $\begin{array}{l}\text { NEXRAD } \\
\text { Grid Cell }\end{array}$ & FOREST & GRASS & WETLAND & LAKE & RIDGE & URBAN & FOREST & GRASS & WETLAND & LAKE & RIDGE & URBAN \\
\hline 122612 & 0.6 & 14.9 & 10.6 & 39.8 & 34.2 & 0.0 & 6 & 147 & 104 & 393 & 338 & 0 \\
\hline 122613 & 0.0 & 20.8 & 19.5 & 50.9 & 0.0 & 8.8 & 0 & 205 & 193 & 504 & 0 & 87 \\
\hline 122614 & 0.0 & 5.0 & 27.3 & 49.7 & 0.0 & 18.0 & 0 & 49 & 270 & 491 & 0 & 178 \\
\hline 123086 & 0.0 & 8.8 & 7.5 & 80.5 & 0.0 & 3.1 & 0 & 87 & 75 & 796 & 0 & 31 \\
\hline 123087 & 0.0 & 15.6 & 16.3 & 68.1 & 0.0 & 0.0 & 0 & 154 & 161 & 673 & 0 & 0 \\
\hline 123088 & 0.0 & 47.8 & 16.4 & 28.9 & 0.0 & 6.9 & 0 & 472 & 162 & 286 & 0 & 68 \\
\hline 123559 & 0.0 & 6.3 & 6.3 & 77.5 & 0.0 & 10.0 & 0 & 62 & 62 & 766 & 0 & 99 \\
\hline 123560 & 0.0 & 23.4 & 8.9 & 67.7 & 0.0 & 0.0 & 0 & 231 & 88 & 669 & 0 & 0 \\
\hline 123561 & 0.0 & 9.3 & 22.4 & 68.3 & 0.0 & 0.0 & 0 & 92 & 221 & 675 & 0 & 0 \\
\hline 124033 & 0.0 & 1.3 & 6.9 & 88.1 & 0.0 & 3.8 & 0 & 12 & 68 & 871 & 0 & 37 \\
\hline 124034 & 0.0 & 26.1 & 16.8 & 57.1 & 0.0 & 0.0 & 0 & 258 & 166 & 565 & 0 & 0 \\
\hline 124035 & 0.0 & 41.3 & 35.6 & 23.1 & 0.0 & 0.0 & 0 & 408 & 352 & 229 & 0 & 0 \\
\hline 124507 & 0.0 & 38.8 & 11.3 & 26.9 & 0.0 & 23.1 & 0 & 383 & 111 & 266 & 0 & 229 \\
\hline 124508 & 0.0 & 43.8 & 27.5 & 15.6 & 0.0 & 13.1 & 0 & 432 & 272 & 154 & 0 & 130 \\
\hline Total acres & & & & & & & 6 & 2,994 & 2,303 & 7,338 & 338 & 859 \\
\hline Percentage & of total poc & 1 area & & & & & 0.0 & 21.6 & 16.6 & 53.0 & 2.4 & 6.2 \\
\hline
\end{tabular}




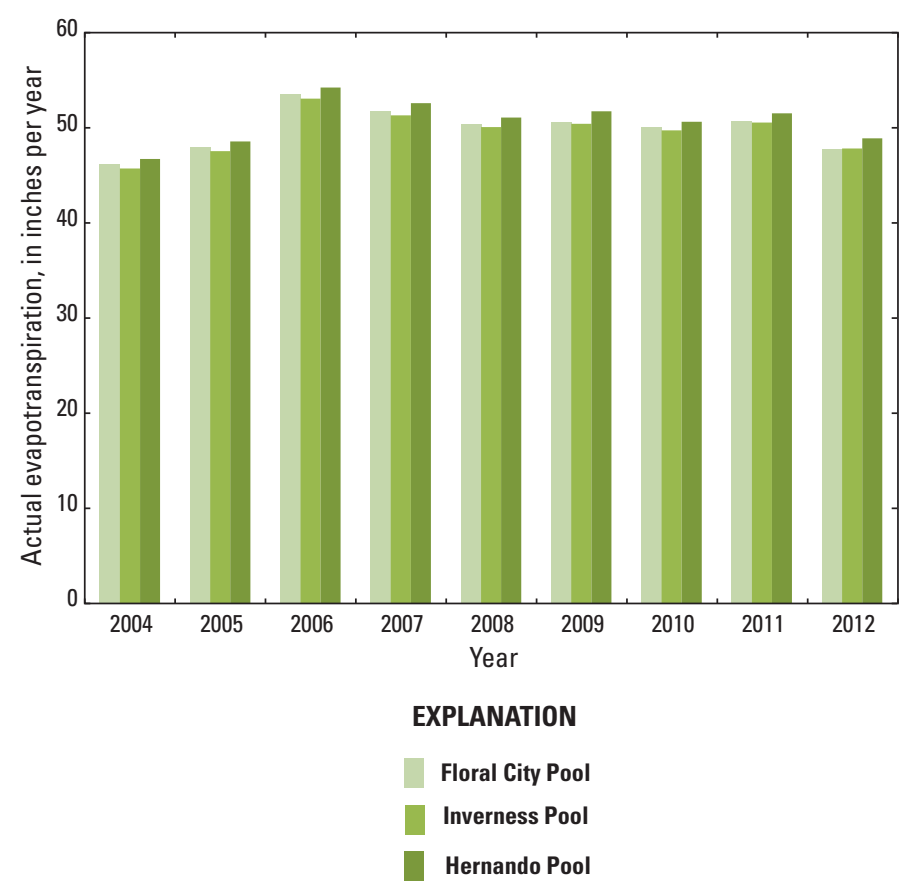

Figure 33. Annual actual evapotranspiration rates for the Floral City Pool, Inverness Pool and Hernando Pool, 2004-12.

evapotranspiration rate (54 in.) of all years during 2004-12. Observations at the Inverness $3 \mathrm{SE}$ weather station indicated a deficit in rainfall of about 14 in. in 2006 relative to the long-term mean (fig. 9). The Floral City and Inverness Pools had storage declines in 2006 of about -16 in., followed by the Hernando Pool at about -12 in. The largest annual increase in storage occurred in 2012 for all three pools, with increases of about 10, 13, and 13 in. for the Floral City, Inverness, and Hernando Pools, respectively. The increase in storage was largely because of above-average rainfall during the wet season, which included Tropical Storm Debby, following an extreme dry period.

\section{Inundated Area of the Pools}

The lakes and connecting wetlands of the Tsala Apopka Lake system are situated in relatively flat topography, and a large change in the inundated area is associated with a small change in surface-water stage. As a result, accurately defining the inundated area of the lakes and connecting wetlands is a critically important component of the water-budget analysis. To understand the inundation characteristics of the three pools, a DEM was used to determine the lake volume associated with a given lake stage. If the land elevation was less than or equal to the lake stage for a pool on a given day then that point was considered inundated. The areas of Tsala Apopka Lake that would be potentially inundated at pool stages of $30-75 \mathrm{ft}$ are shown in figure 36 .

The minimum and maximum inundated area for each pool varied substantially (figs. 37-39), which shows the effect of the flat topography. The daily mean of percent inundated area during 2004-12 was calculated for each pool (fig. 40). From 2004 to 2012, the inundated area of the Floral City Pool ranged from 616 acres ( 5 percent) to 6,892 acres ( 55 percent) of the total 12,495 acres in the pool (figs. 37 and 40A). The median inundated area for the Floral City Pool was 4,680 acres or 37 percent of the total acreage. The Inverness Pool varied in inundated area from 1,213 acres (11 percent) to 6,193 acres (57 percent) of the total 10,774 acres (figs. 38 and 40B). The median inundated area was 3,378 acres ( 31 percent). Of the total 11,257 acres in the Hernando Pool, inundated area ranged from 843 (7 percent) to 8,142 acres ( 72 percent) and the median was 2,737 acres ( 24 percent) of the total pool area (figs. 39 and 40C).

The time series of inundation for each pool (fig. 40) illustrates a more rapid response of inundation in the Floral City Pool, with a step-pattern that is typical for regulated streams and reservoirs. This pattern contrasts with the Hernando Pool during the water-budget period, which has spikes in the hydrographs that is a typical response to rainfall events. These patterns may occur because the Floral City Pool receives the most surface-water inflow (18 in/yr) from the Withlacoochee River, whereas the Hernando Pool is the farthest downstream of the pools and receives the least surface-water inflow (6 in/yr, tables 6 and 8). Since 2010, Tsala Apopka Lake has been managed by SWFWMD so that surface-water inflows are shared equally among the three pools. The Hernando Pool is relatively flat, which limits storage, but would also result in change in inundation area that is more sensitive to rainfall events. After large rainfall events or large volumes of surface-water inflow, the inundated area in the Floral City Pool was the fastest to decline, possibly indicating leakage to the groundwater system, release of storage to downstream pools, or less storage capacity in surrounding wetlands.

\section{Computed Surface-Water Inflows and Outflows}

Surface-water diversions from the Withlacoochee River through the Tsala Apopka system are regulated by 12 gated structures that help move or control surface-water flows between pools (fig. 3). For the water-budget analysis described herein, the term "computed structure inflow" refers to the contribution of all surface waters that flow through structures into a pool, whereas "computed structure outflow" refers to the contribution of all surface waters that flow through structures out of a pool.

From 2004 to 2012, the Floral City Pool had the largest volume of computed structure inflow, followed by the Inverness Pool and the Hernando Pool (fig. 41 and table 12). For all years within the water-budget period, some measurable 


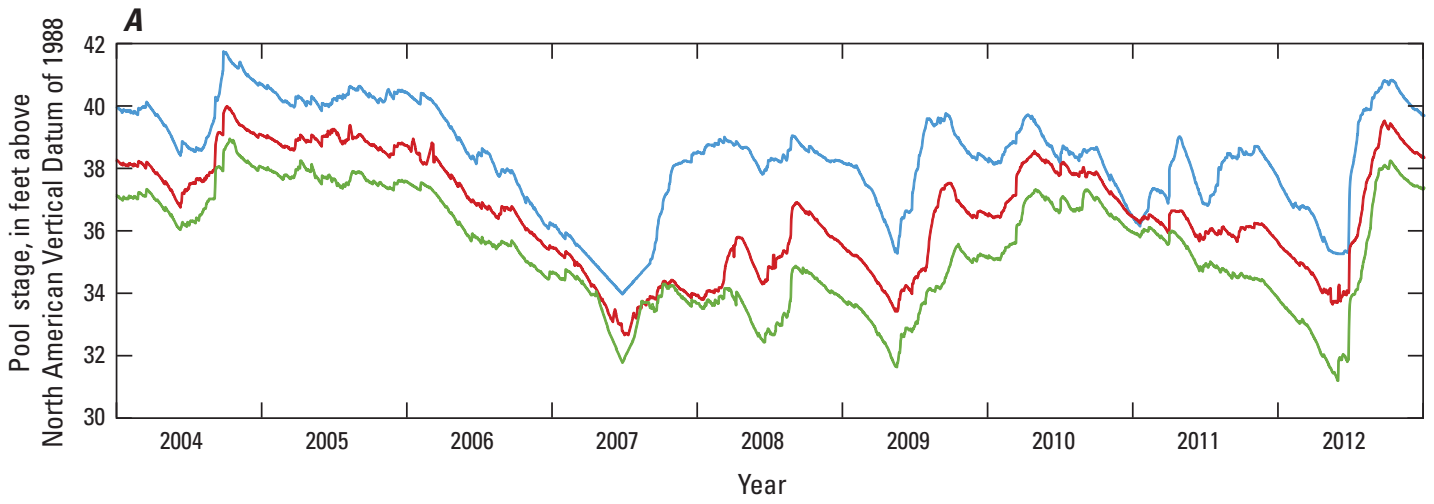

EXPLANATION

Floral City Pool (Floral City Lake - Southwest Florida Water Management District 22908)

Inverness Pool (Henderson Lake - Southwest Florida Water Management District 23481)

Hernando Pool (Hernando Lake - Southwest Florida Water Management District 23609)

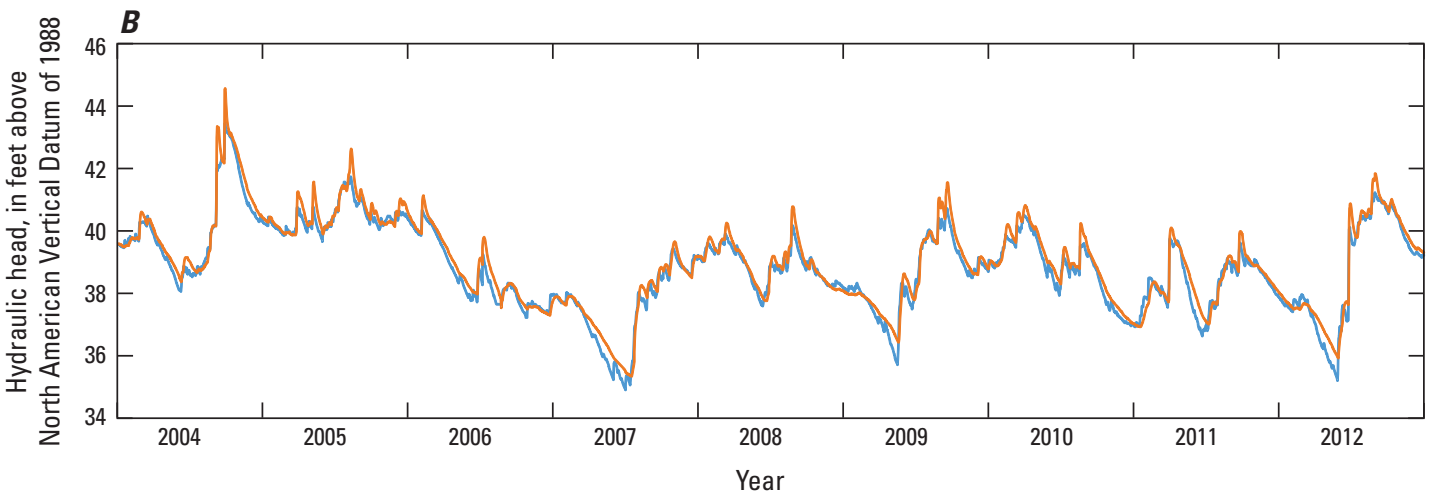

EXPLANATION

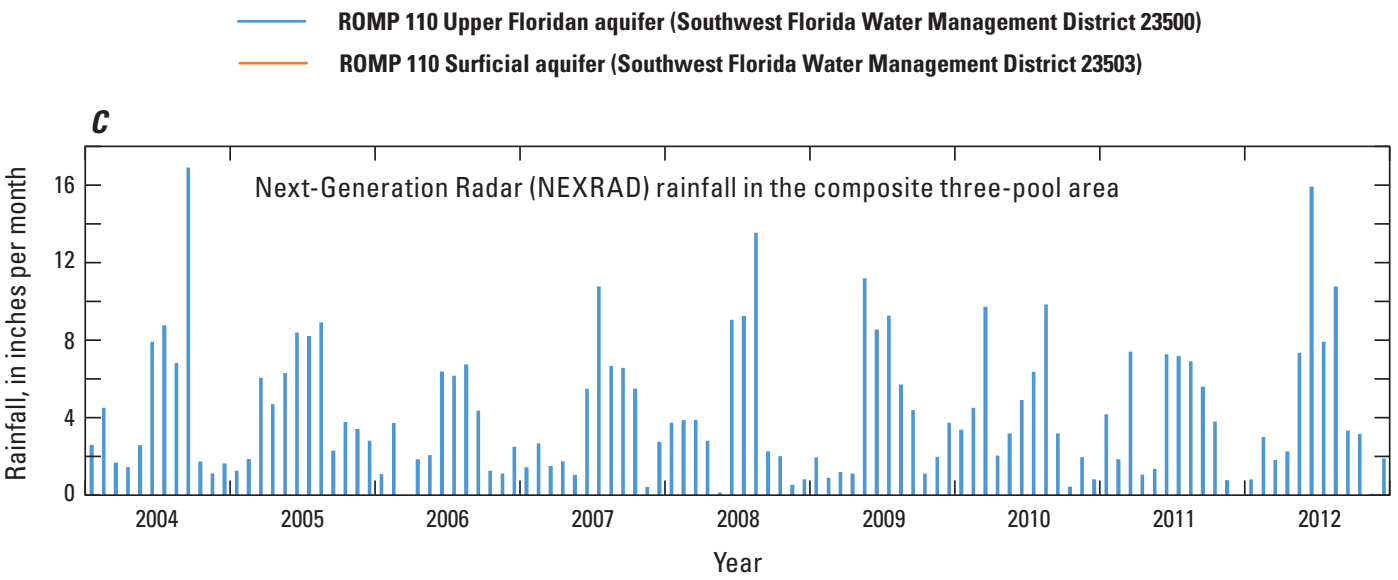

Figure 34. Time series of daily mean $A$, pool stage; $B$, hydraulic head; and $C$, monthly rainfall in the Tsala Apopka Lake area, 2004-12 (Southwest Florida Water Management District, 2017c). Site information available in table 1 and figure 4. 

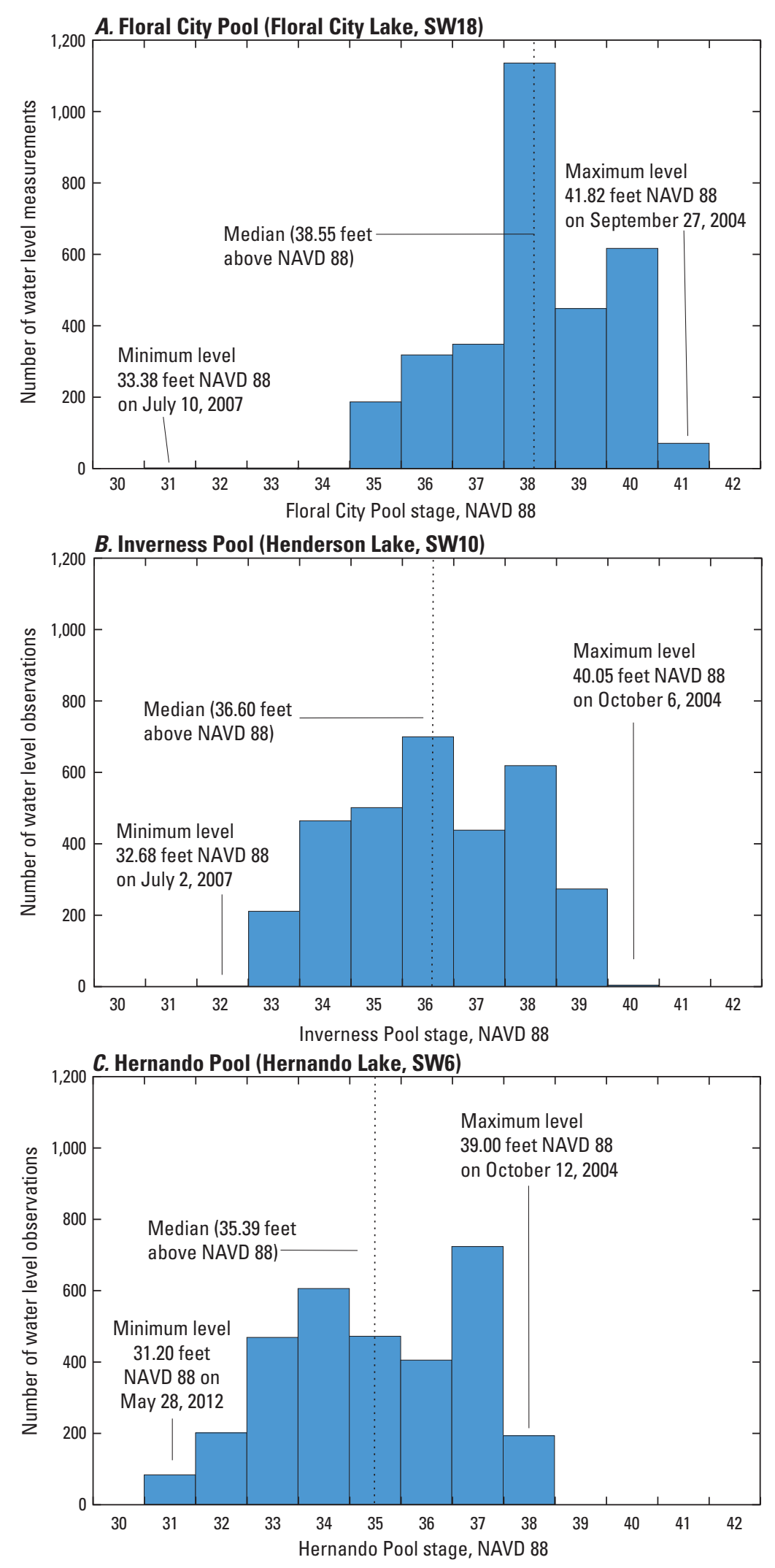

Figure 35. Statistical distribution of water stage data in the $A$, Floral City Pool; $B$, Inverness Pool; and $C$, Hernando Pool, 2004-12 (Southwest Florida Water Management District, 2017c). Each number on the $x$-axis represents the range of pool stages for that integer. For example, 35 represents pool stages between 35.00 and 35.99 feet. Site information available in table 1 and figure 4. 


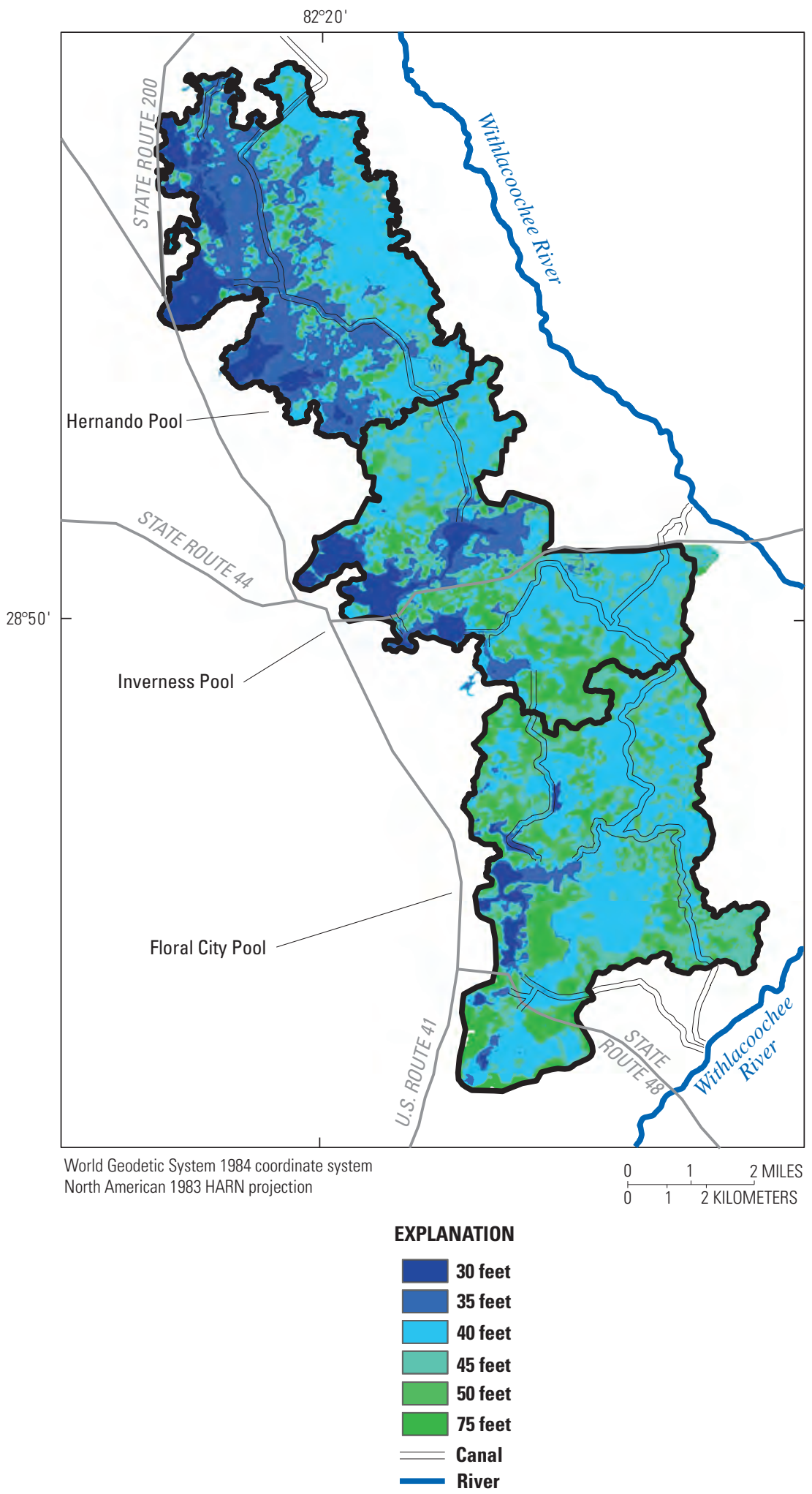

Figure 36. Areas of potential inundation in the Floral City Pool, Inverness Pool, and Hernando Pool at stages of 30-75 feet above the North American Vertical Datum of 1988. 


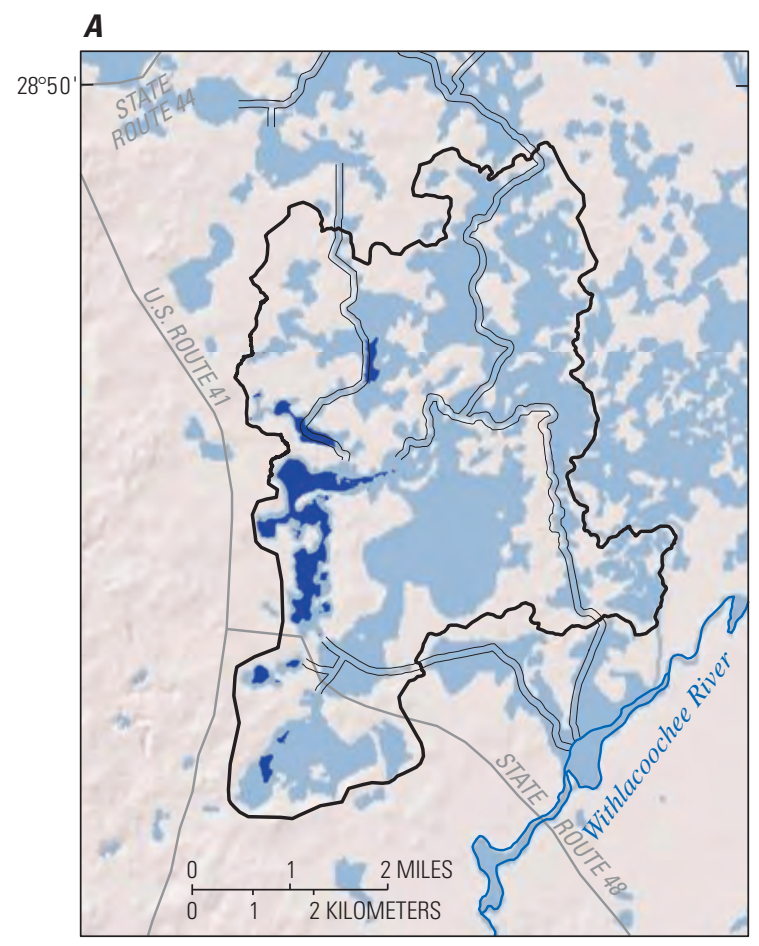

World shaded relief basemap from Esri

World Geodetic System 1984 coordinate system

Mercator Auxillary Sphere projection

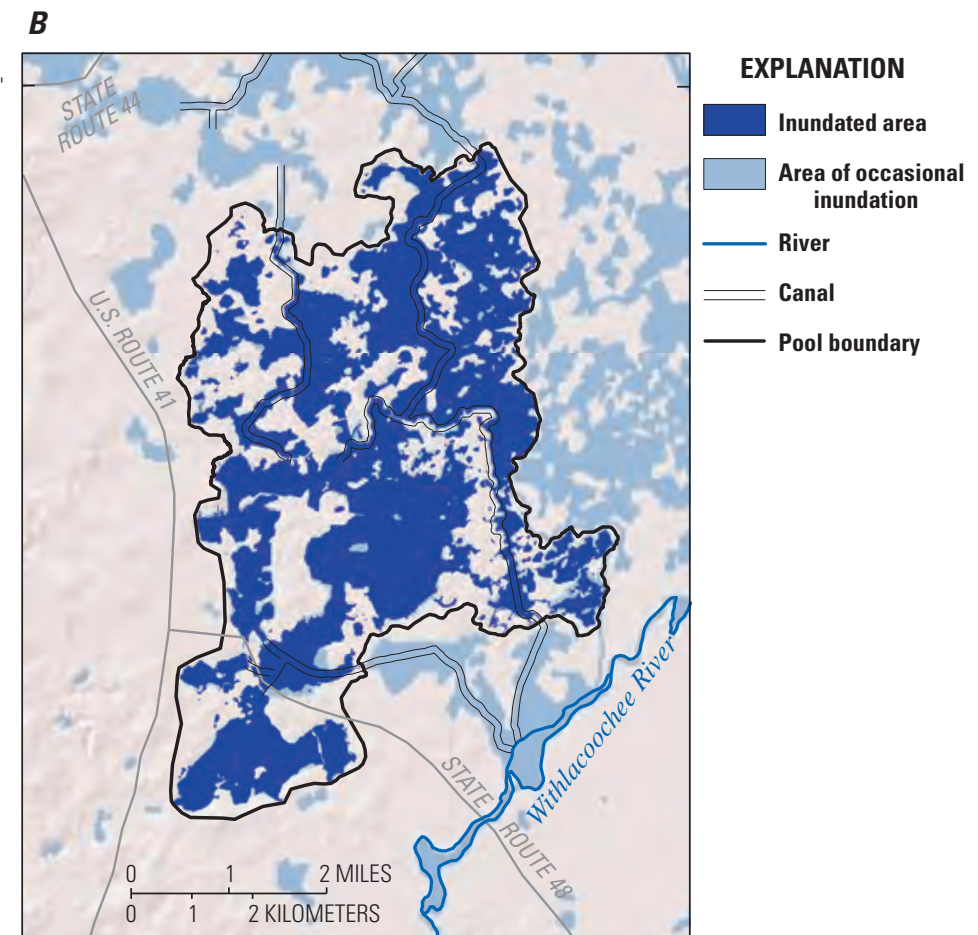

World shaded relief basemap from Esri

World Geodetic System 1984 coordinate system

Mercator Auxillary Sphere projection

Figure 37. Minimum and maximum inundated areas in the Floral City Pool, 2004-12. $A$, The minimum stage 33.38 feet above the North American Vertical Datum of 1988, occurred July 10, 2007. B, The maximum stage 41.82 feet, occurred September 27, 2004.
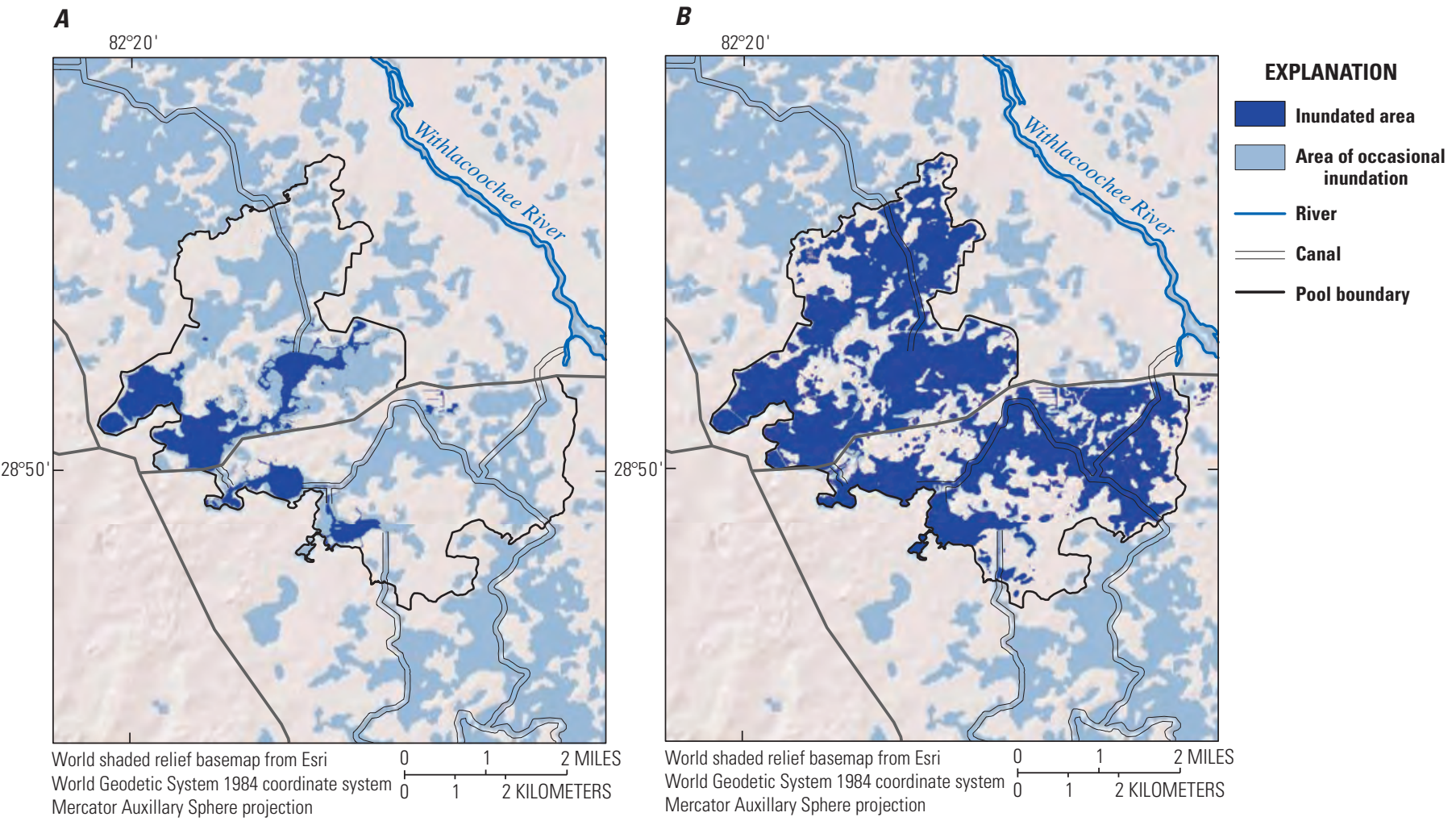

Figure 38. Minimum and maximum inundated areas in the Inverness Pool, 2004-12. A, The minimum stage, 32.68 feet above the North American Vertical Datum of 1988, occurred July, 2 2007. B, The maximum stage, 40.05 feet, occurred October 6, 2004. 

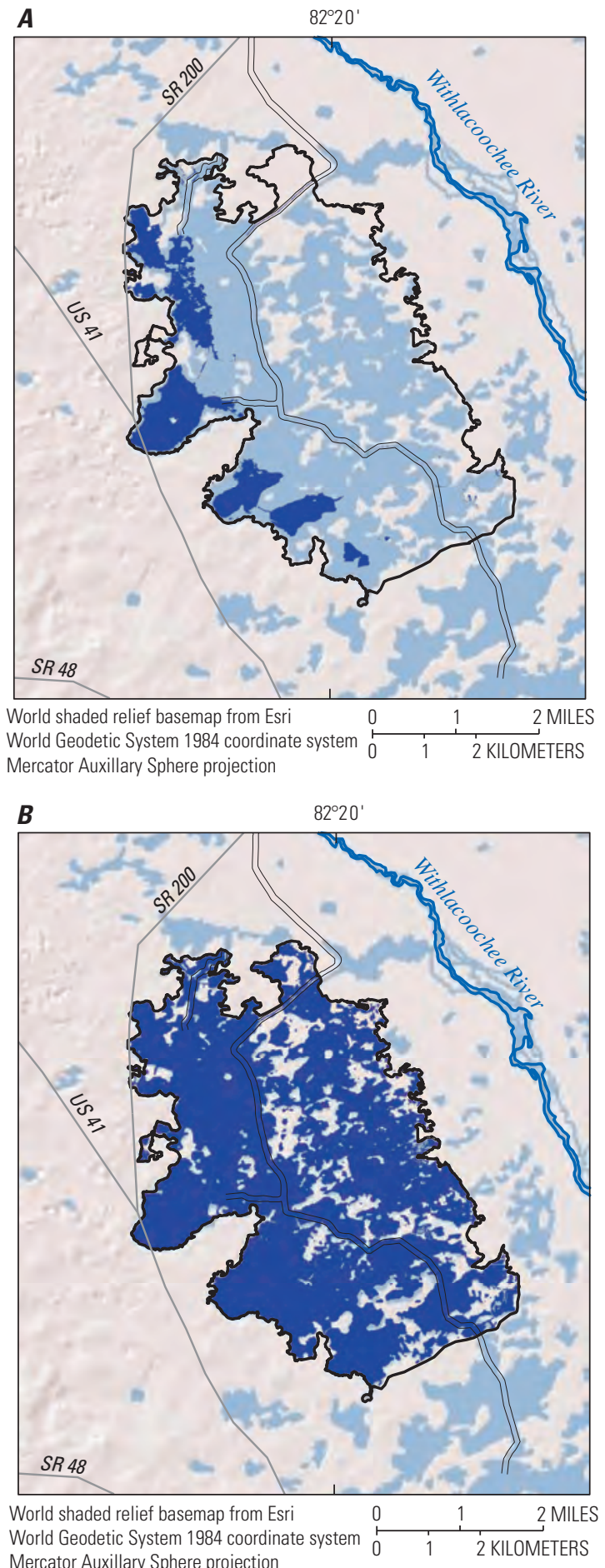

Mercator Auxillary Sphere projection

\section{EXPLANATION}

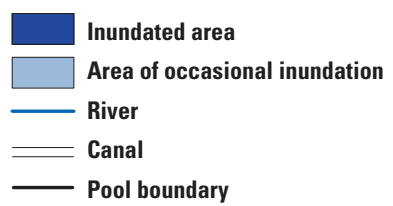

Figure 39. Minimum and maximum inundated areas in the Hernando Pool, 2004-12. A, The minimum stage, 31.20 feet above the North American Vertical Datum of 1988, occurred May 28, 2012. $B$, The maximum stage, 39.00 feet, occurred October 12, 2004.
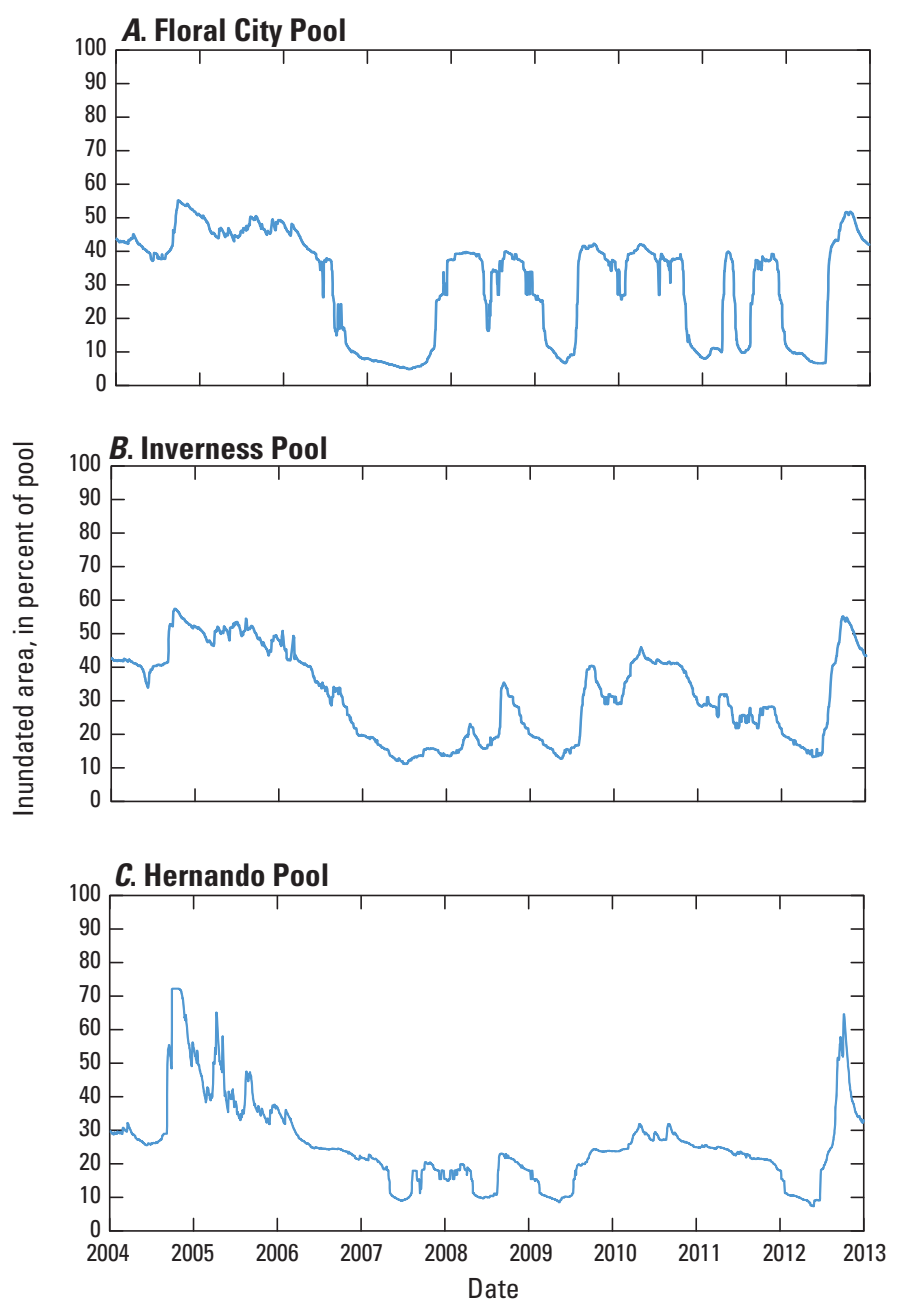

Figure 40. Daily mean of percent inundated area of the $A$, Floral City Pool; $B$, Inverness Pool; and $C$, Hernando Pool, 2004-12. 
computed structure inflow occurred from the Withlacoochee River to the Floral City Pool. The Inverness Pool had no computed structure inflow or outflow in 2006-07 and no outflow in 2008. The Hernando Pool had no computed structure inflow in 2006-08 and no outflow in 2006-11 (fig. 41 and table 12).

The largest annual computed structure inflow during the water-budget period occurred in 2012 for all three pools (Floral City Pool $\left[29,031 \mathrm{ft}^{3} / \mathrm{s} ; 55.3 \mathrm{in} / \mathrm{yr}\right.$ over the fixed pool boundary]; Inverness Pool [15,772 ft $\mathrm{ft}^{3} / \mathrm{s} ; 34.8 \mathrm{in} / \mathrm{yr}$ over the fixed pool boundary]; and Hernando Pool [8,807 ft $\mathrm{t}^{3} \mathrm{~s}$; $18.6 \mathrm{in} / \mathrm{yr}$ over the fixed pool boundary]; fig. 41; table 12). Following a prolonged dry period, Tropical Storm Debby (June 24-27, 2012) brought approximately 16 in. of rainfall to the Tsala Apopka Lake chain-of-lakes and sufficiently increased stages along the Withlacoochee River to allow for large structure inflows to each pool. Following the storm, some of the structures, including Brogden Bridge culverts, Bryant Slough, and Van Ness, flowed for the first time since 2005.

The structures at Tsala Apopka Lake are operated to provide inflow from the Withlacoochee River when water stages in the river are higher than the Floral City Pool and when the major lakes are below their target stages (SWFWMD, 2010). If the Floral City or Leslie Heifner structures are left open when the Withlacoochee River drops below the Floral City Pool, reversal of structure flow can occur. Reverse flow occurred from the Floral City Pool to the Withlacoochee River for brief periods in 2009, 2011, and 2012 (fig. 41 and table 12). The amounts of reverse structure flow ranged from 1 to $13 \mathrm{ft}^{3} / \mathrm{s}$. The Inverness Pool is connected directly to the Withlacoochee River by way of Bryant Slough. Flow from the river to the Inverness Pool (through Bryant Slough) was considered an outflow in the water-budget calculations. During the water budget period, outflow through Bryant Slough Structure was observed only in 2004, when mean flow was calculated to be $47 \mathrm{ft}^{3} / \mathrm{s}(0.1 \mathrm{in} / \mathrm{yr})$.

From 2004 to 2012, the Floral City Pool had the largest volume of computed structure outflow $\left(15,787 \mathrm{ft}^{3} / \mathrm{s} ; 30.1 \mathrm{in} / \mathrm{yr}\right.$; 2012), followed by the Inverness Pool $\left(8,947 \mathrm{ft}^{3} / \mathrm{s} ; 19.8 \mathrm{in} / \mathrm{yr}\right.$; 2012), and the Hernando Pool (6,255 ft/s; $13.2 \mathrm{in} / \mathrm{yr} ; 2004)$ (fig. 41; table 12). The Floral City and Inverness Pools had no computed structure outflow during 2006-07 and 2006-08, respectively. The Hernando Pool had substantial computed structure outflow only in 2004-05, when high-water stages necessitated the release of water to the Withlacoochee River and Two Mile Prairie.

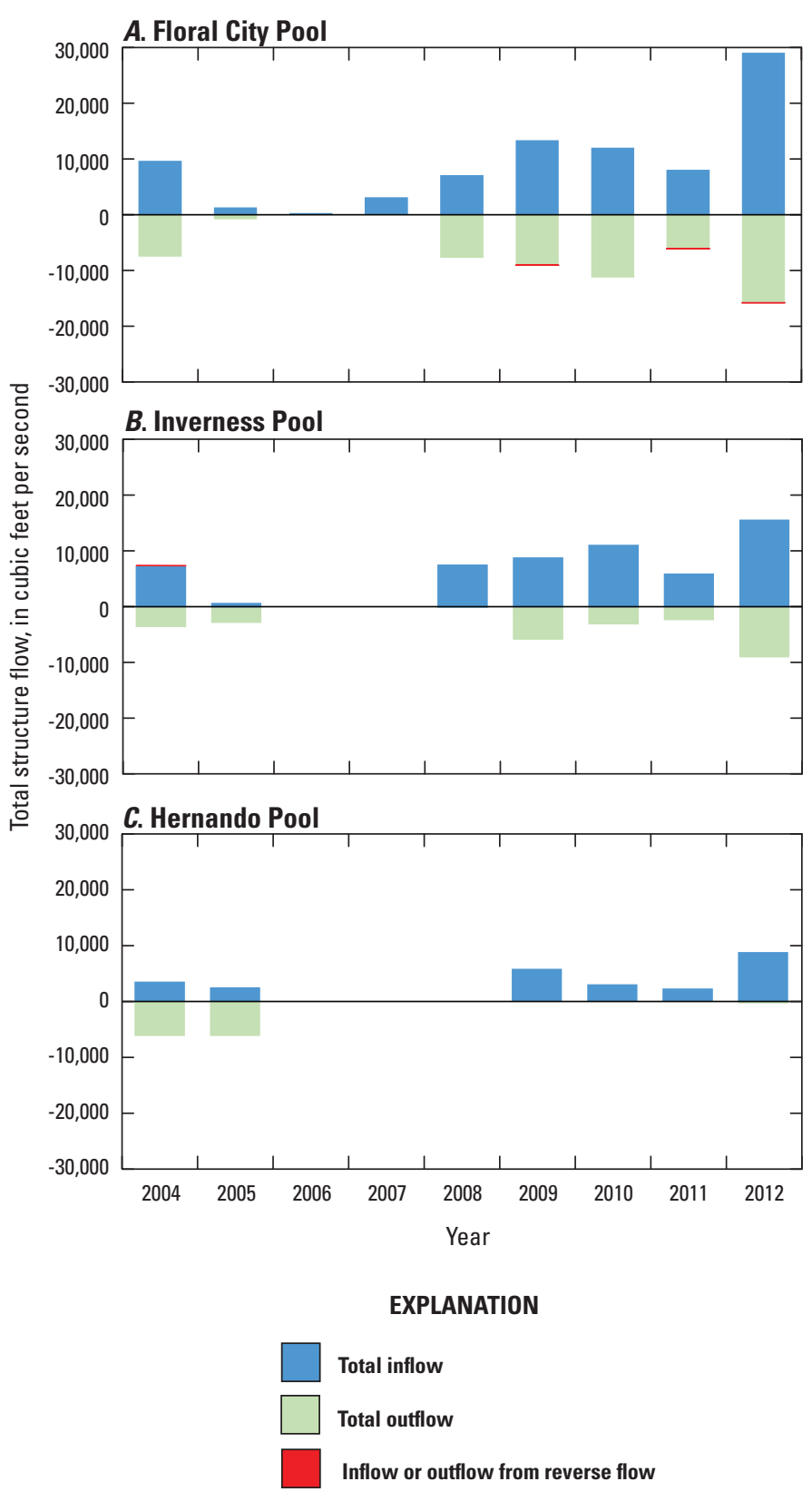

Figure 41. Computed surface-water inflows and outflows for the $A$, Floral City Pool; $B$, Inverness Pool; and $C$, Hernando Pool, 2004-12. 
Table 12. Calculated surface-water flows for Tsala Apopka Lake structures, 2004-12.

[ft $\mathrm{ft}^{3} / \mathrm{s}$, cubic feet per second; in/yr, inches per year; R, reverse flow]

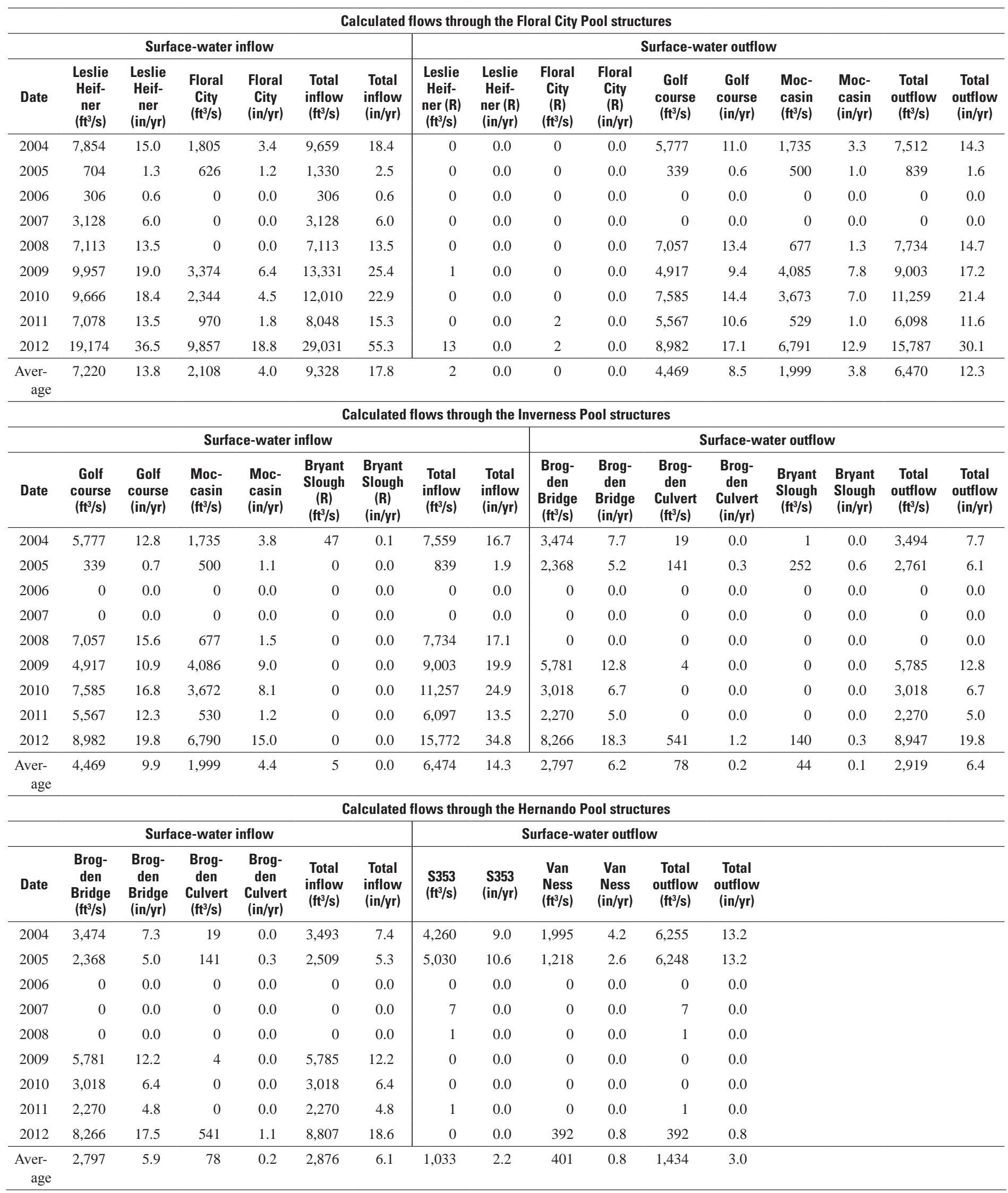




\section{Net Groundwater Flow}

During 2004-12, the water-budget analysis indicated that annual values of $G_{\text {net }}$ outflow usually exceeded $G_{\text {net }}$ inflow for the three pools. Annual $\mathrm{G}_{\text {net }}$ ranged from -24 to $5 \mathrm{in} / \mathrm{yr}$ in the three pools (fig. 42 and tables 6-8). Negative values indicate that downward leakage of surface water to groundwater exceeded upward leakage of flow to the surface. From 2004 to 2012, the Floral City Pool, Inverness Pool, and Hernando Pool mean $G_{\text {net }}$ rates were $-7,-9$, and -4 in/yr, respectively. The composite three-pool area had a mean rate of $-7 \mathrm{in} / \mathrm{yr}$ for the same period. For a number of years at each pool where the error $\left(e_{G \text { net }}\right)$ was potentially greater than the absolute value of groundwater flow, such as at Inverness Pool in 2007 and 2009 (fig. 42, table 7), it is possible that the actual $G_{\text {net }}$ is the opposite in direction of that indicated for the mean net flow for that year, but this only happens during periods when net flow is nearing neutral conditions. Net groundwater flow varied considerably between pools, which may be related to differences in the number of karst features in each pool and the variable surface-water inflow rates that increase the vertical head differences between the surface-water and groundwater systems.

\section{Results of the Water-Budget Analysis}

The water-budget analysis indicated that rainfall was the largest water input and AET was the largest water output for Tsala Apopka Lake, which is typical of seepage lakes in Florida (Sacks and others, 2014). Based on the data found in table 9, the mean composite water-budget inputs, as a percent of the total for the 9-year (2004-12) analysis period, include 11 percent for surface-water inflow, 88 percent for rainfall, and 1 percent for $G_{\text {net }}$ inflow (for this summary, years with positive $G_{\text {net }}$ were counted as inflow and years with negative $G_{\text {net }}$ were counted as outflow). The mean of the composite water-budget outputs, as a percent of the total for the 9-year period, include 2 percent surface-water outflow, 12 percent $G_{\text {net }}$ outflow, and 86 percent evapotranspiration. Although the long-term means of the inputs and outputs are useful for identifying the largest components of the budget during the 9-year water-budget period, they can be misleading in regards to the annual water budgets because they can differ substantially in individual years, which is especially true for budget terms that can be both positive and negative, such as storage and $G_{\text {net }}$. For instance, the mean change in storage for 2004-12 was zero, but storage was a major component of the budget in 2006 (-15 in/yr) and 2012 (12 in/yr) (table 9).
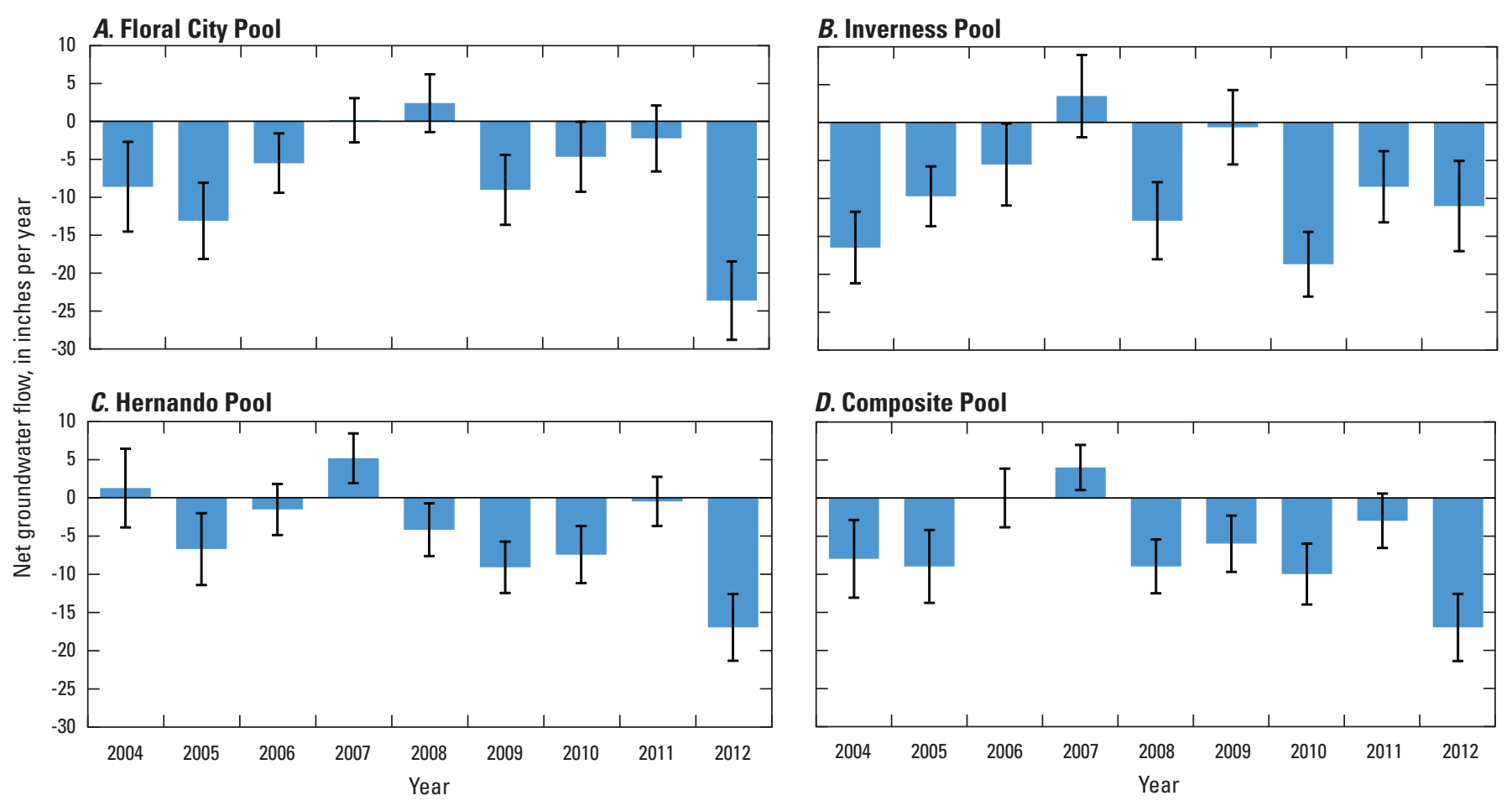

Figure 42. Annual variability of net groundwater flow for the $A$, Floral City Pool; $B$, Inverness Pool; $C$, Hernando Pool; and $D$, composite three-pool area, 2004-12. Positive values indicate groundwater inflow and negative values indicate groundwater outflow (leakage). Error bars indicate the maximum calculated error of each net groundwater flow estimate. 
For the annual water budgets, $G_{\text {net }}$ outflow from the surficial aquifer exceeded $G_{\text {net }}$ inflow for the three pools during most of the 9-year period. The driest year (2006), wettest year (2012), and average over the water-budget period (2004-12) had a $G_{\text {net }}$ outflow for all pools (figs. 42 and 43). Hydraulichead data collected from paired Upper Floridan aquifer and surficial aquifer wells indicated that the vertical hydraulic gradient between the two aquifers increases from east to west across the pools, which is illustrated in figures 19-21. East of the major lakes the hydraulic heads in the Upper Floridan aquifer and surficial aquifer are nearly equal (fig. 19), and the Upper Floridan aquifer and surficial aquifer seem to act as a single, connected aquifer system, particularly during wet years. The lack of a vertical hydraulic gradient between the surficial aquifer and Upper Floridan aquifer indicates that recharge potential is low in this area. Near the western shore of the major lakes in all three pools, hydraulic head in the Upper Floridan aquifer was lower than that of the surficial aquifer and major lakes during the data collection period (October 2011-September 2014). The difference between lake stages and groundwater levels in the Upper Floridan aquifer were about $10 \mathrm{ft}$ for Floral City and Hernando Pools at the Floral City and Hernando Lakes, respectively, and about $4 \mathrm{ft}$ for the Inverness Pool at Henderson Lake (fig. 20). Most of the recharge to the Upper Floridan aquifer likely occurs in the western one-half of the pools because the difference in hydraulic head is greatest there.

Net groundwater inflow from the control volume (wetlands, lakes, and the surficial aquifer) for each pool exceeded outflow during several years of the water-budget period, such as in Floral City Pool in 2008, Inverness Pool in 2007, and Hernando Pool in 2004 and 2007, though usually within the range of calculated error for $G_{\text {net }}$ (fig. 42 , tables 6-8). The hydraulic head of the Upper Floridan aquifer rarely exceeded that of the surficial aquifer or major lakes anywhere in the three pools, except in isolated locations for brief periods (figs. 19-21). The Upper Floridan aquifer does not likely contribute considerable groundwater inflow to the control volume of the three pools under typical hydrologic conditions. Positive $G_{\text {net }}$ inflow should not be interpreted as spring flow or seepage of Upper Floridan aquifer groundwater directly into the major Tsala Apopka lakes because there was no indication of Upper Floridan aquifer discharge directly to the major lakes at any time (fig. 20). It is possible that positive $G_{\text {net }}$ is an artifact of lateral surficial flow/runoff into the control volume if the areal boundaries of the pools are not "hard" no-flow boundaries. Conditions for positive discharge occurred most often following major rainfall events after a rise in groundwater levels (fig. 44), which are also the most likely conditions for flow to cross the fixed pool boundaries. If flow is crossing the pool boundaries, then it is not properly accounted for in the water budget and the positive $G_{\text {net }}$ results may not be real, but positive $G_{\text {net }}$ results tended to be small and usually fell within the maximum $e_{G \text { net }}$ for that year. The degree of positive groundwater discharge varied depending on the amount of rainfall and the hydrologic conditions in the pools prior to the event. Most years of the 9-year water-budget period experienced at least 1 month of positive groundwater discharge conditions, but in the annual budgets these positive periods were usually offset by longer and more intense periods of net loss. Inflow does likely occur within the control volume, from the surficial aquifer to the major lakes, because hydraulic head in the surficial aquifer was often higher than lake stage during wet periods (fig. 20).

Years with large $G_{\text {net }}$ outflow (negative values) in the three pools, such as 2012, were associated with large surfacewater inflows to the pools from the Withlacoochee River. Inflows increase the head difference between the lakes/ wetlands and the groundwater system, which results in an increased potential for vertical leakage to the underlying aquifers. Metz and Sacks (2002) determined that augmenting lakes with groundwater artificially raises lakes stages, which increases recharge potential. Inflows from the Withlacoochee River to the Tsala Apopka Lake pools are controlled by structures, which could have a similar effect when lake levels are higher than groundwater levels in the surficial aquifer (fig. 20). Lack of confinement or breaches in the intermediate confining unit can facilitate the downward movement of surface water to the Upper Floridan aquifer. Loss of storage from lakes might also occur as horizontal flow to the surficial aquifer along the perimeter of the lakes because surface-water inflow raises lake and wetland stages above the adjacent groundwater table elevation, creating a potential for lateral leakage to the surficial aquifer (Metz and Sacks, 2002; Lee and others, 2009). This loss of storage to the surficial aquifer would be internal to the control volume, so it would have no impact on the water budget calculations. 


\section{A. Average for 2004-12, inches per year}

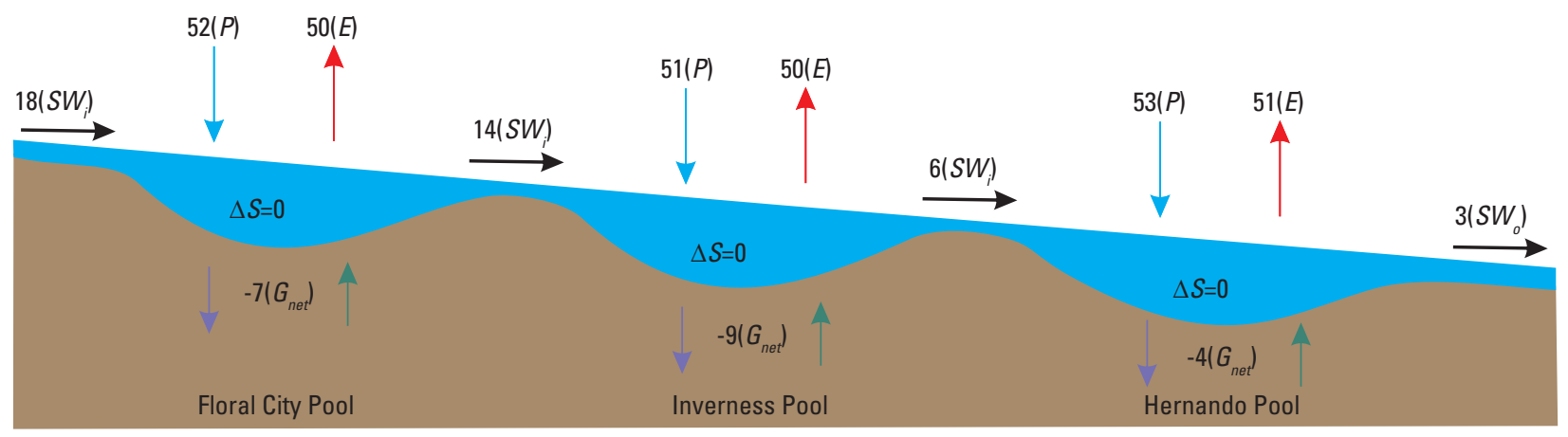

B. Dry year, 2006, inches per year

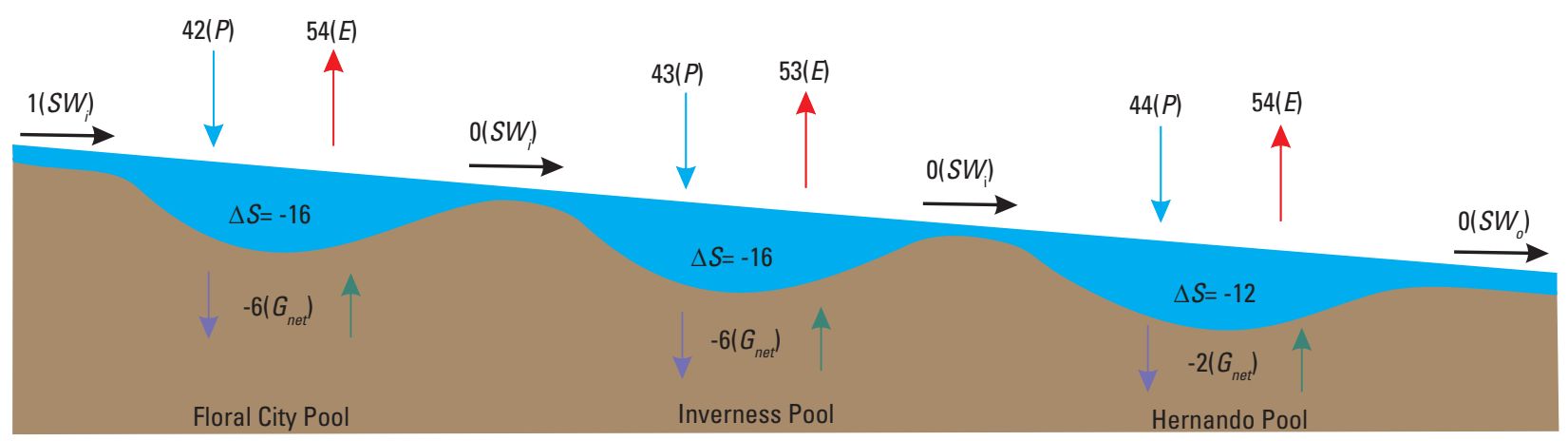

C. Wet year, 2012, inches per year

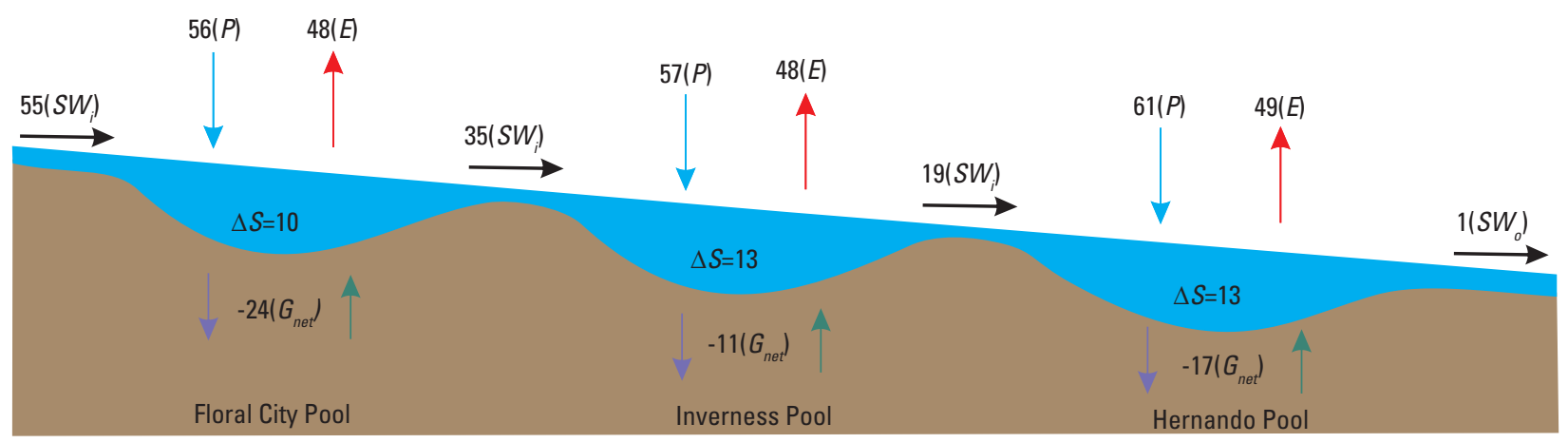

\section{EXPLANATION}

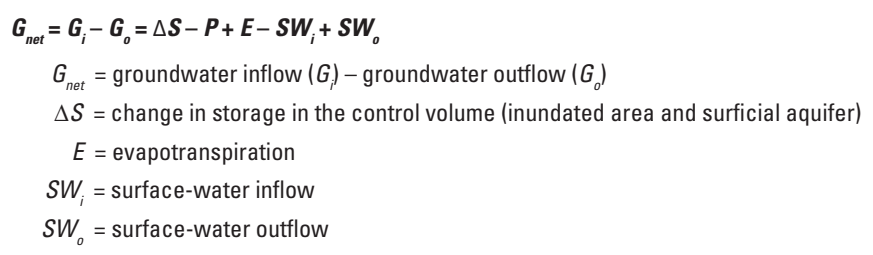

Figure 43. Water-budget diagrams for the control volumes of Floral City Pool, Inverness Pool, and Hernando Pool showing the annual mean water budget for $A, 2004-12$; $B$, a dry year (2006); and $C$, a wet year (2012). Overall, 2004-12 was a dry period with mean precipitation below the long-term mean (based on weather station records for 1930-2014). 

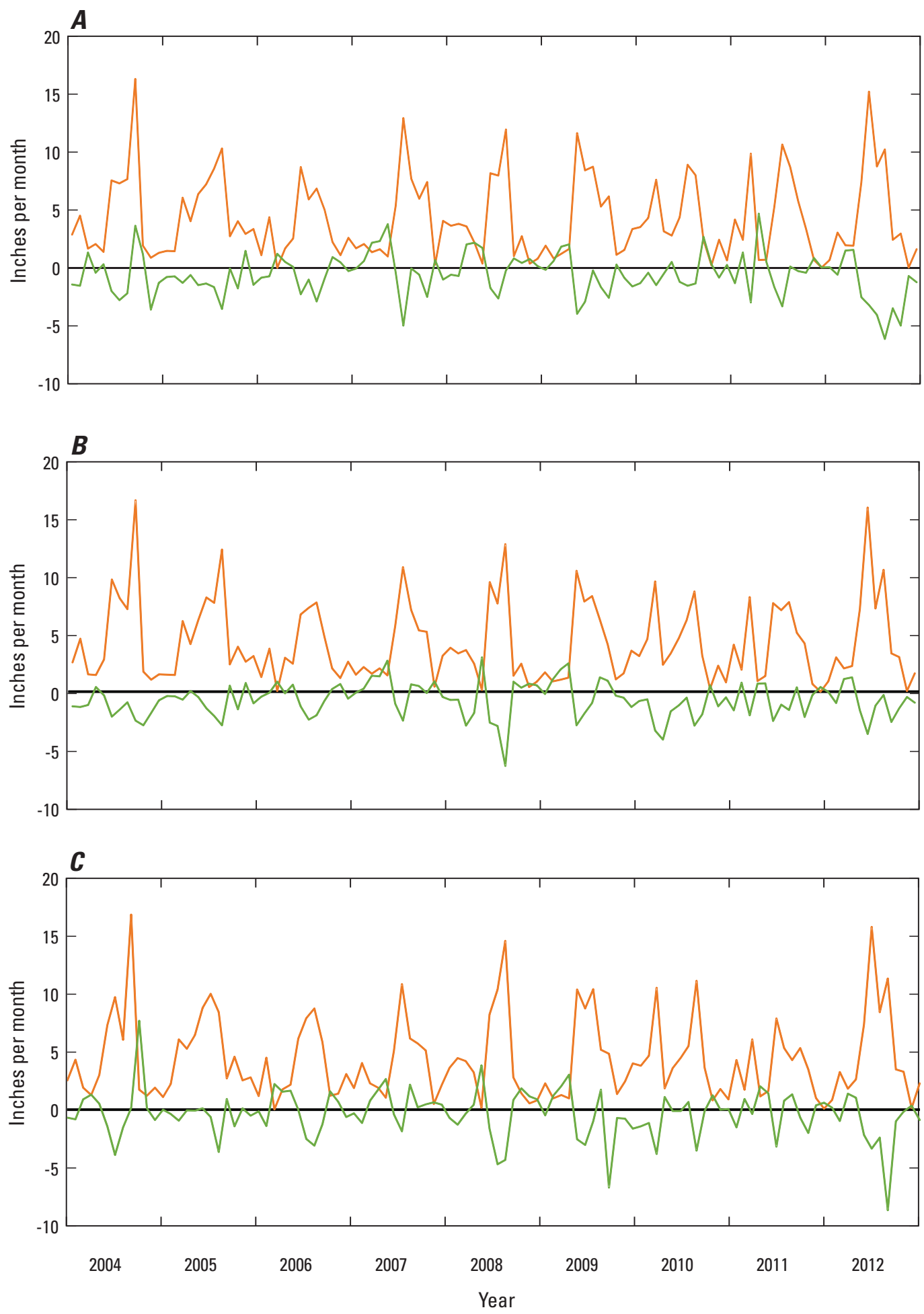

EXPLANATION

NEXRAD rainfall

Net groundwater flow $\left(G_{\text {net }}\right)$

Figure 44. Comparisons of monthly Next-Generation Radar (NEXRAD) rainfall (Southwest Florida Water Management District, 2017e) and computed net groundwater flow $\left(\mathrm{G}_{\text {net }}\right)$ in the $A$, Floral City Pool; $B$, Inverness Pool; and $C$, Hernando Pool, 2004-12. 


\section{Summary}

Tsala Apopka Lake is a complex system of interconnected lakes and wetlands, with intervening uplands, located in Citrus County in west-central Florida. It is located within the 2,100 square mile watershed of the Withlacoochee River, which drains north and northwest towards the Gulf of Mexico. The Tsala Apopka Lake consists of three hydrologically distinct pools that are managed by the Southwest Florida Water Management District. From upstream to downstream the pools are Floral City Pool, Inverness Pool, and Hernando Pool. Water flows to Tsala Apopka Lake from the Withlacoochee River, which flows along the eastern edge of the lake system. When conditions permit, water from the Withlacoochee River flows through a series of canals and gravity-fed control structures to the pools. Tsala Apopka Lake is a challenge to manage as a water resource due to its complex network of interconnecting canals and structures. Understanding how water moves through the system and interacts with the underlying aquifer, using geochemical indicators and a water-budget approach, would give water managers better insight into how to manage the system.

Tsala Apopka Lake is an area of karst terrain, and unique challenges can arise in protecting surface-water and groundwater quality because of the complex surface hydrologic connectivity and the close hydraulic connection of the surface environment to the relatively shallow and karstic Upper Floridan aquifer. Therefore, hydrologic and hydrogeologic data were needed to understand the interactions between groundwater and surface water. Hydrogeologic units in the study area include the surficial aquifer, intermediate confining unit, and the Floridan aquifer system. The surficial aquifer is exposed at the land surface and consists of the undifferentiated Tertiaryage and Quaternary-age sediments. Beneath the surficial aquifer are the sands and clays of the intermediate confining unit, which coincide with the sediments of the Miocene-age undifferentiated Hawthorn Group and Coosawhatchie Formation. Below the intermediate confining unit is the Floridan aquifer system, which is present throughout Florida and consists of Tertiary-age carbonate rocks, including the Avon Park Formation and overlying Ocala Limestone. The Floridan aquifer system is further subdivided into the Upper Floridan aquifer and Lower Floridan aquifer.

Spatial variations in geology in the region affect the areal distribution of groundwater discharge and recharge. East of the Withlacoochee River, in the vicinity of Lake Panasoffkee, groundwater discharge conditions exist in the surficial aquifer and Upper Floridan aquifer. This is related to the thinning of the Ocala Limestone (uppermost unit of the Upper Floridan aquifer), which reduces the transmissivity of the Upper Floridan aquifer because the underlying Avon Park Formation lacks the hydraulic conductivity of the Ocala Limestone. Such conditions do not exist west of the Withlacoochee River, where the Ocala Limestone thickens and the transmissivity of the Upper Floridan aquifer increases in the Tsala Apopka Lake area.
Groundwater levels were measured continuously at a set of 10 paired well locations from 2011 to 2014 and 38 wells synoptically in May and October 2012. Groundwater-level data were used to evaluate the hydraulic connection between the surficial aquifer and the Upper Floridan aquifer. The continuous-recording well pairs had one well completed in the surficial aquifer and the second within the Upper Floridan aquifer, and groundwater-level data were collected primarily from September 1, 2011, to October 1, 2014, but varied somewhat depending on well completion dates. In the area of mixed wetlands and uplands between the major Tsala Apopka lakes and the Withlacoochee River, groundwater levels in wells in the surficial and Upper Floridan aquifers were nearly equal during most of the study period, indicating that the two aquifers essentially act as a single system. Following heavy rains, surficial-aquifer levels briefly rose above the level of the Upper Floridan aquifer at many sites, indicating slight downward recharge potential from the surficial to the Upper Floridan aquifer. At one paired well site, the Upper Floridan aquifer sometimes exceeded the level of the surficial aquifer, indicating upward discharge potential. Near the major Tsala Apopka lakes, in the western part of the pools, water levels were always higher in the surficial aquifer than in the Upper Floridan aquifer, typically by 4 to 10 feet (ft). The difference in head between the aquifers indicated that the surficial aquifer had strong recharge potential to the Upper Floridan aquifer. Generally, recharge potential to the Upper Floridan aquifer increased from east to west across Tsala Apopka Lake. In the vicinity of the major Tsala Apopka lakes, the surficial aquifer was often at higher levels than the lakes for brief periods following heavy rains. Because the major lakes are fully incised into the surficial aquifer, or nearly so, the discharge most likely occurs along lake perimeters as horizontal flow in the surficial aquifer.

The depth to the potentiometric surface of the Upper Floridan aquifer below land surface can vary between dry periods (May and June 2012) and wet periods (September and October 2012). The depth to the Upper Floridan aquifer below land surface is least on the eastern side of the study area and greatest to the west where the lakes are situated. During times of high water or drought, there remains a downward leakage of surface water into the Upper Floridan aquifer along the western side of the pools, where the deeper lakes contain geology that is affected by karst features.

Major ion data indicate that all of the major water sources in the Tsala Apopka Lake study area are a calcium-bicarbonate type water, including the surface-water system, surficial aquifer, and Upper Floridan aquifer. The primary source of calcium bicarbonate in the area are the limestones of the Upper Floridan aquifer. The presence of calcium bicarbonate in surface water is often an indication of groundwater discharge, but hydraulic-head data indicated that the potential for upward discharge was low in the Tsala Apopka Lake area for most of the study period. Signatures of groundwater from the Upper Floridan aquifer might reflect the geochemistry of areas of groundwater discharge from the Upper Floridan aquifer, 
located upstream from Tsala Apopka Lake and along the Withlacoochee River. Several factors can likely account for the prevalence of calcium-bicarbonate type water in the study area, including inflow from the Withlacoochee River, the thinness of the surficial aquifer and frequent limestone outcrops, and localized upward discharge of the Upper Floridan aquifer under certain conditions. Previous studies have shown that much of the Withlacoochee River is a groundwater discharge area. Calcium-bicarbonate type water from the Withlacoochee River feeds the Tsala Apopka lakes through a series of canals when the stage of the river is high enough for inflow to occur (and water-control structures are opened). Throughout the study area, surface water also frequently contacts limestone where it crops out at the land surface and where it is exposed along lake and canal bottoms. Under wet conditions the Upper Floridan aquifer likely discharges flow to the surficial aquifer in isolated locations.

Groundwater and surface-water samples collected in the study area mostly contained strontium-87/strontium- 86 $\left.{ }^{87} \mathrm{Sr} /{ }^{86} \mathrm{Sr}\right)$ isotope ratios consistent with the limestones of the Upper Floridan aquifer, which is further evidence of the importance of Upper Floridan aquifer groundwater to Tsala Apopka Lake. Most samples from the Upper Floridan aquifer contained ${ }^{87} \mathrm{Sr} /{ }^{86} \mathrm{Sr}$ ratios consistent with a mixed-water source from the Avon Park Formation and Ocala Limestone. The Ocala Limestone is thin in the study area, as little as $20 \mathrm{ft}$ thick, so many of the Upper Floridan aquifer wells are installed either near the top of the Avon Park Formation or partially in it, which results in a mixed sample. The ${ }^{87} \mathrm{Sr} /{ }^{86} \mathrm{Sr}$ ratios of samples collected from the major lakes and canals were mostly consistent with that of the Ocala Limestone, which likely reflects the effect of the Withlacoochee River on the lake system.

Groundwater samples collected near the western shorelines of the major Tsala Apopka lakes contained enriched deuterium/hydrogen $(\delta \mathrm{D})$ and oxygen-18/oxygen-16 $\left(\delta^{18} \mathrm{O}\right)$ isotope ratios consistent with a surface-water source that has undergone evaporation or other forms of fractionation. The likely source of the evaporated water was the major lakes immediately upgradient of the Upper Floridan aquifer wells, such as Floral City Lake, Henderson Lake, and Hernando Lake. Samples from Upper Floridan aquifer wells located between the major lakes and the Withlacoochee River mostly did not contain an enriched $\delta \mathrm{D}$ and $\delta^{18} \mathrm{O}$ signature. The lack of enrichment in these samples is an indication that the wetlands in the vicinity of these wells do not provide substantial recharge to the Upper Floridan aquifer, as was also demonstrated by the water-level data collected at paired wells in the area, which mostly indicated neutral recharge potential. Therefore, the major lakes in the Tsala Apopka Lake system seemed to be a source of recharge to the Upper Floridan aquifer, whereas the wetlands east of the major lakes and west of the Withlacoochee River likely did not contribute substantial recharge.

The apparent ages of groundwater samples from the Upper Floridan aquifer in the study area were less than
50 years old and were considered young. The apparent age of water in samples from the Upper Floridan aquifer was relatively uniform across the study area. The differences in the apparent ages of the groundwater produced by individual wells was most likely related more to well depth and the length of each well's open interval than the spatial location of each well. Data collected from paired surficial aquifer and Upper Floridan aquifer wells were limited, but the difference in apparent age for the paired samples at each site varied from 16 to 19 years, which is an indication of the time that is required for the average parcel of water to recharge from the surficial aquifer to the Upper Floridan aquifer in the study area.

Surface topography and long-term lake-stage data were used to determine the boundaries of the three pools for waterbudget analysis. Using this method, the topographical high boundaries set for each pool correspond to surface elevations of 42.5, 41.0, and $39.5 \mathrm{ft}$ in the Floral City, Inverness, and Hernando Pools, respectively. Using these methods, following the same order, the size of the pools were determined to be 12,$495 ; 10,774$; and 11,257 acres. The control volume for the water budget extended to the base of the surficial aquifer within the pool area.

The major components of the water-budget analysis included surface-water and groundwater storage, rainfall, actual evapotranspiration, surface-water inflows and outflows, and groundwater inflows and outflows. Daily changes in lake stages and groundwater levels were used to define the annual change in storage for each pool. Stage-volume curves were developed for each pool to determine the change in surfacewater storage, whereas the water-table fluctuation method was used to determine the change in groundwater storage. From 2004 to 2012, the largest storage decline occurred in 2006 in the three-pool area as a result of an 11-inch (in.) rainfall deficit and the highest measured evapotranspiration rate (about 54 in.). The largest increase in storage occurred in 2012, based on above-average rainfall (about 58 in.) and relatively low evapotranspiration (about 48 in.).

The Tsala Apopka Lake area is situated in a relatively flat topography, so small changes in water elevation result in large changes in inundated area. Accurately defining the surface elevation was critical to understanding the daily fluctuations of the inundated area. Daily inundated area was defined for each pool using a lake volume to lake stage relationship developed on the basis of an incremental increase in stage applied over a digital elevation model for each pool area. If the elevation associated with the surface-volume data was less than or equal to lake stage on a given day, then the point was considered inundated. From 2004 to 2012, the minimum and maximum inundated area for each pool was 616-6,892 acres in the Floral City Pool; 1,213-6,193 acres in the Inverness Pool; and 843-8,142 acres in the Hernando Pool.

For the three-pool area, rainfall was determined using 2-kilometer $\times$ 2-kilometer gridded Next-Generation Radar (NEXRAD) data that were validated by comparing with ground-based measurements. The analysis indicated that the two datasets were not statistically different. The long-term 
mean of rainfall in the study area for 1930-2014 at the Inverness $3 \mathrm{SE}$ weather station was 54 inches per year. In the three-pool area, annual rainfall ranged from about 43 to 60 inches per year from 2004 to 2012 and had a mean of 52 in. during the same period. The most substantial rainfall during the water-budget period occurred during a 3-week period in the summer of 2004 when three hurricanes made landfall in Florida and resulted in about $17 \mathrm{in}$. of rainfall. The driest year of the water-budget period was 2006, when there was only 43 in. of rain.

Evapotranspiration was calculated as a function of reference evapotranspiration and adjusted to actual evapotranspiration on the basis of monthly land-use coefficients. Reference evapotranspiration was available at a 2-kilometer $\times 2$-kilometer grid, equivalent to that of the NEXRAD grid. Land-cover types in the pool areas included forest, grass, wetland, lake, ridge, and urban. The monthly land-use coefficients ranged from 0.45 for ridge in January to 1.18 for lake in August. Lake was the most abundant land type, varying from about 36 to 53 percent of the total land area in each pool. Wetland and open water accounted for about 69 percent of the acreage in the composite threepool area. For the three-pool area, 2004 had the lowest actual evapotranspiration rate at 46 inches per year, whereas 2006 was the highest at 54 inches per year. The lowest actual evapotranspiration rates coincided with the wettest years, which was inferred to be associated with increased cloud cover.

Surface-water inflows and outflows to the pools were determined at water-control structures and were estimated using a hydraulic modeling approach calibrated to fieldmeasured discharge data. The modeling approach was necessary because long-term flow records were not available. Step-backwater calculations were performed for each structure that included headwater, tail water, height of gate openings, structure coefficients, channel roughness values, and crosssectional flow areas. For the 2004-12 water budget period, Floral City Pool had the largest volume of structure inflow, followed by the Inverness Pool and Hernando Pool. Floral City Pool receives inflow directly from the Withlacoochee River when river stages are high enough for gravity flow to occur. Floral City Pool received some inflow from the river every year of the study. The Inverness Pool had no structure inflow in 2006-07 and no outflow in 2006-08. The Hernando Pool had no structure inflow in 2006-08 and no outflow in 2006-11. The largest inflows for the water-budget period occurred in 2012 for all three pools: Floral City Pool, 29,031 cubic feet per second; Inverness Pool, 15,772 cubic feet per second, and Hernando Pool, 8,807 cubic feet per second. The largest outflows also occurred in 2012 for Floral City and Inverness Pools at 15,787 and 8,947 cubic feet per second, respectively. The highest outflows for Hernando Pool were in 2004 at a rate of 6,255 cubic feet per second.

Net groundwater flow was calculated as a residual term in the water budget. Negative values indicate that downward leakage of surface water exceeded upward (or lateral) leakage of groundwater to the surface-water system. Downward leakage exceeded upward leakage 8 out 9 years in the composite three-pool area. Net annual groundwater flow had a mean of -7 inches per year in the Floral City Pool, -9 inches per year in the Inverness Pool, and -4 inches per year in the Hernando Pool from 2004 to 2012 and annual means ranged from -24 to $2,-19$ to 3 , and -17 to 5 inches per year, respectively.

The water-budget analysis indicated that rainfall was the largest water input and evapotranspiration was the largest water output for the Tsala Apopka Lake system. The mean values of the composite water-budget inputs, as a percent of the total for the analysis period, are 11 percent for surfacewater inflow, 88 percent for rainfall, and 1 percent for groundwater inflows (years with positive net groundwater flow were counted as inflows, while years with negative net groundwater flow were counted as outflows). The mean values of the composite water-budget outputs, as a percent of the total, are 2 percent surface-water outflow, 12 percent net groundwater outflow, and 86 percent evapotranspiration. This analysis indicates that rainfall, with lesser emphasis on surface-water inflows, was the most important component to the sustainability of the Tsala Apopka Lake system.

Surface-water inflows to the Tsala Apopka Lake system from the Withlacoochee River also increases the head difference between the lakes/wetlands and the surficial aquifer, which results in an increased potential for vertical leakage to the underlying Upper Floridan aquifer. The difference in groundwater levels in the surficial aquifer and Upper Florida aquifer was about $10 \mathrm{ft}$ for wells located near major lakes in both the Hernando and Floral City Pools and $4 \mathrm{ft}$ for the Inverness Pool.

In conclusion, Tsala Apopka Lake is primarily an area of groundwater recharge for the Upper Floridan aquifer. Recharge potential is highest in the western part of the study area near the major lakes. In most years, net groundwater outflow exceeds net groundwater inflow. In dry years during the water-budget period, annual actual evapotranspiration was estimated to exceed annual rainfall. Water-budget calculations indicate that rainfall is the dominant source of input of water to the Tsala Apopka Lake pools and evapotranspiration is the dominant source of output.

\section{References Cited}

Arthur, J.D., Fischler, Cindy, Kromhout, Clint, Clayton, J.M., Kelley, G.M., Lee, R.A., Li Li, O’Sullivan, Mike, Green, R.C., and Werner, C.L., 2008, Hydrogeologic framework of the Southwest Florida Water Management District: Florida Geological Survey Bulletin No. 68, 102 p.

Attardi, V.J., 1983, An environmental description of Lake

Tsala Apopka Lake: Southwest Florida Water Management District, Environmental Section Technical Report 1983-4, $64 \mathrm{p}$. 
Bradner, L.A., 1988, Hydrology of the Floral City Pool of Tsala Apopka Lake, west-central Florida: U.S. Geological Survey Water-Resources Investigations Report 88-4024, $44 \mathrm{p}$.

Brenton, R.W., and Arnett, T.L., 1993, Methods of analysis by the U.S. Geological Survey National Water Quality Laboratory-Determination of dissolved organic carbon by UVpromoted persulfate oxidation and infrared spectrometry: U.S. Geological Survey Open-File Report 92-480, 12 p.

Buickerood, M., Mann, J., Wylupek, Q., and Romie, K., 1990, Lake Tsala Apopka Lake Environmental Assessment: Southwest Florida Water Management District Lake Levels Project, $291 \mathrm{p}$.

Busenberg, Eurybiades, and Plummer, L.N., 2000, Dating young groundwater with sulfur hexafluoride-Natural and anthropogenic sources of sulfur hexafluoride: Water Resources Research, v. 36, no. 10, p. 3011-3030.

Busenberg, Eurybiades, Plummer, L.N., Bartholomay, R.C., and Wayland, J.E., 1998, Chlorofluorocarbons, sulfur hexafluoride, and dissolved permanent gases in ground water from selected sites in and near the Idaho National Engineering and Environmental Laboratory, Idaho, 1994-1997: U.S. Geological Survey Open-File Report 98-274, 72 p.

Bush, R.W., and Johnston, R.H., 1988, Ground-water hydraulics, regional flow, and ground-water development of the Floridan aquifer system in Florida and in parts of Georgia, South Carolina, and Alabama: U.S. Geological Survey Professional Paper 1403-C, 80 p., 17 pls.

Chow, V.T., Maidment, D.R., and Mays, L.W., 1988, Applied hydrology: New York, McGraw-Hill, 572 p.

Clark, I.D., and Fritz, Peter, 1997, Environmental isotopes in hydrogeology: Lewis Publishers, Boca Raton, Fla., 328 p.

Cook, P.G., and Bohlke, J.K., 2000, Determining time scales for groundwater flow and solute transport, chap. 1 of Cook, P.G., and Herczeg, A.L., eds., Environmental tracers in subsurface hydrology: Boston, Kluwer Academic Publishers, p. $1-30$.

Cooke, C.W., 1945, Geology of Florida: Florida Geological Survey Geological Bulletin No. 29, 339 p.

Copeland, Rick, Scott, T.M., Lloyd, J.M., and Maddox, Gary, 1991, Florida's ground water quality monitoring network hydrogeologic framework: Florida Geological Survey, Special Publication No. 32, 97 p.

Coplen, T.B., 1994, Reporting of stable hydrogen, carbon, and oxygen isotopic abundances: Pure and Applied Chemistry, v. 66 , p. 273-276.
Coplen, T.B., Wildman, J.D., and Chen, J., 1991, Improvements in the gaseous hydrogen-water equilibration technique for hydrogen isotope ratio analysis: Analytical Chemistry, v. 63, p. 910-912.

Craig, Harmon, 1961, Isotopic variations in meteoric waters: Science, v. 133, no. 3465 , p. 1702-1703.

Davidian, J., 1984, Computation of water-surface profiles in open channels: U.S. Geological Survey Techniques of Water-Resources Investigations, book 3, chap. A15, 48 p.

Dawson, Tiffany, 2007, Exploratory drilling and monitor-well construction at Lake Tsala-Apopka (Flying Eagle) Citrus County, Florida: Southwest Florida Water Management District, Regional Observation and Monitor-Well Section, $10 \mathrm{p}$.

Decker, J.L., 1983, ROMP 109 “Old Story Mine”: Southwest Florida Water Management District Executive Summary 19-020-51XX, 4 p.

DePaolo, D.J., and Ingram, B.L., 1985, High-resolution stratigraphy with strontium isotope: Science, v. 227, p. 938 941.

Dooris, P.M., 1978, Environmental monitoring within the Southwest Florida Water Management District with recommendations concerning stream and lake water quality sampling: Southwest Florida Water Management District Environmental Section Technical Report 1978-8, 42 p.

Epstein, S., and Mayeda, T., 1953, Variation of O-18 content of water from natural sources: Geochimica et Cosmochimica Acta, v. 4, p. 213-224.

Faires, L.M., 1993, Methods of analysis by the U.S. Geological Survey National Water Quality Laboratory-Determination of metals in water by inductively coupled plasma-mass spectrometry: U.S. Geological Survey Open-File Report 93-125, $217 \mathrm{p}$.

Faulkner, G.L., 1973, Geohydrology of the Cross-Florida Barge Canal with special reference to the Ocala vicinity: U.S. Geological Survey Water-Resources Investigations Report 73-1, $117 \mathrm{p}$.

Fernald, E.A., and Purdum, E.D., eds., 1998, Water resources atlas of Florida: Institute of Science and Public Affairs, Florida State University, 312 p.

Fetter, C.W., 1994, Applied hydrogeology (3d ed.): New York, Macmillan College Publishing, Inc., 616 p.

Fishman, M.J., ed., 1993, Methods of analysis by the U.S. Geological Survey National Water Quality LaboratoryDetermination of inorganic and organic constituents in water and fluvial sediments: U.S. Geological Survey OpenFile Report 93-125, 217 p. 
Fishman, M.J., and Friedman, L.C., 1989, Methods for determination of inorganic substances in water and fluvial sediments: U.S. Geological Survey Techniques of WaterResources Investigations, book 5, chap. A1, 545 p.

Florida Fish and Wildlife Conservation Commission, 2008, Diagnostic survey of sediment and vegetation of the Tsala Apopka Lake Chain of Lakes: PB Americas, Project No. FWC04/05-17, v. 1-4. [Also available at http://www.citrusbocc.com/pubworks/aquatics/tsala-apopka/ sediment-vegetation-study.htm.]

Freeze, R.A., and Cherry, J.A., 1979, Groundwater: New Jersey, Prentice-Hall, Inc., 604 p.

Garbarino, J.R., 1999, Methods of analysis by the U.S. Geological Survey National Water Quality LaboratoryDetermination of dissolved arsenic, boron, lithium, selenium, strontium, thallium, and vanadium using inductively coupled plasma-mass spectrometry: U.S. Geological Survey Open-File Report 99-093, 31 p.

Gonfiantini, R., 1986, Environmental isotopes in lake studies, in Fritz, P., and Fontes, J., eds., Handbook of environmental isotope geochemistry: Elsevier, Amsterdam, The Netherlands, v. 2, p. 113-168.

Green, R.C., Williams, C.P., Burdette, K.E., Bassett, S.W., Flor, A.D., and Paul, D.T., 2011, Geologic map of the eastern portion of the USGS Inverness 30 x 60 minute quadrangle, central Florida: Florida Geological Survey Open-File Map Series 102, scale 1:100,000, 3 pls.

Harrison, T.J., Hubbell, P.G., and Brass, N.B., 1981, Rating curves for the structures on the Tsala Apopka Lake chain of lakes, Citrus County, Florida: Southwest Florida Water Management District, 28 p.

Healy, R.W., and Cook, P.G., 2002, Using groundwater levels to estimate recharge: Hydrogeology Journal, v. 10, p. 91-109.

Healy, R.W., Winter, T.C., LaBaugh, J.W., and Franke, O.L., 2007, Water budgets - Foundations for effective waterresources and environmental management: U.S. Geological Survey Circular 1308, 90 p.

Hinkle, S.R., Shapiro, S.D., Plummer, L.N., Busenberg, Eurybiades, Widman, P.K., Casile, G.C., and Wayland, J.E., 2010, Estimates of tracer-based piston-flow ages of groundwater from selected sites-National Water-Quality Assessment Program, 1992-2005: U.S. Geological Survey Scientific Investigations Report 2010-5229, 90 p.
Hoblit, B.C., Castello, C., Liu, L., and Curtis, D., 2003, Creating a seamless map of gage-adjusted radar rainfall estimates for the state of Florida: Proceedings of the EWRI World Water and Environmental Congress, Philadelphia, Pennsylvania, June 23-26, 2003. [Also available at http://dx.doi. org/10.1061/40685(2003)215.]

Horstman, Tiffany, 2011, Tsala Apopka well installation summary and notification of completion as of July 2011: Southwest Florida Water Management District, Regional Observation and Monitor-Well Section, $31 \mathrm{p}$.

HydroGeoLogic, 2013, Northern District Groundwater Flow Model version 4.0: Prepared for St. Johns River Water Management District, Southwest Florida Water Management District, Marion County, and Withlacoochee Regional Water Supply Authority, 755 p.

Johnson, A.I., 1967, Specific yield-Compilation of specific yields for various materials: U.S. Geological Survey Water-Supply Paper 1662-D, 72 p. [Also available at https://pubs.usgs.gov/wsp/1662d/report.pdf.]

Katz, B.G., and Bullen, T.D., 1996, The combined use of ${ }^{87} \mathrm{Sr} /{ }^{86} \mathrm{Sr}$ and carbon and water isotopes to study the hydrochemical interaction between groundwater and lakewater in mantled karst: Geochimica et Cosmichimica Acta, v. 60, no. 24 , p. $5075-5087$.

Katz, B.G., Coplen, T.B., Bullen, T.D., and Davis, J.H., 1997, Use of chemical and isotopic tracers to characterize the interactions between ground water and surface water in mantled karst: Ground Water, v. 35, no. 6, p. 1014-1028.

Kendall, M.G., 1938, A new measure of rank correlation: Biometricka, v. 30, p. 81-93.

Kinnaman, S.L., and Dixon, J.F., 2008, Potentiometric surface of the Upper Floridan aquifer in the St. Johns River Water Management District and vicinity, Florida, September 2007: U.S. Geological Survey Open-File Report 2008-1085, 1 sheet.

LaRoche, J.L., 2012, Hydrogeology, water, quality, and well construction at the ROMP 119.5-Ross Pond well site in Marion County, Florida: Southwest Florida Water Management District, $359 \mathrm{p}$.

Lee, T.M., Haag, K.H., Metz, P.A., and Sacks, L.A., 2009, Comparative hydrology, water quality, and ecology of selected natural and augmented freshwater wetlands in West-Central Florida: U.S. Geological Survey Professional Paper 1758, $152 \mathrm{p}$.

Ludin, A., Weppernig, R., Bonisch, G., and Schlosser, P., 1998, Mass spectrometric measurement of helium isotopes and tritium in water samples: Palisades, N.Y., LamontDoherty Earth Observatory, Columbia University, Technical Report 98.6. 
Maddox, G.L., Lloyd, J.M., Scott, T.M., Upchurch, S.B., and Copeland, Rick, eds., 1992, Florida Ground Water Quality Monitoring Program-Volume 2, Background hydrogeochemistry: Florida Geological Survey, Special Publication no. 34, 364 p.

Mahler, B.J., Personné, J.-C., Lods, G.F., and Drogue, C., 2000, Transport of free and particulate-associated bacteria in karst: Journal of Hydrology, v. 238, p. 179-193.

McBride, W.S., Bellino, J.C., and Swancar, Amy, 2011, Hydrology, water budget, and water chemistry of Lake Panasoffkee, west-central Florida: U.S. Geological Survey Scientific Investigations Report 2010-5237, 96 p.

McBride, W.S., and Wacker, M.A., 2015, Depth-dependent groundwater quality sampling at City of Tallahassee test well 32, Leon County, Florida, 2013: U.S. Geological Survey Open-File Report 2014-1255, 13 p. and 2 appendixes. [Also available at https://dx.doi.org/10.3133/ ofr20141255.]

McKinney, C.R., McCrea, J.M., Epstein, S., Allen, H.A., and Urey, H.C., 1950, Improvements in mass spectrometers for the measurement of small differences in isotope abundance ratios: Review of Scientific Instruments, v. 21, p. 724-730.

Mecikalski, J.R., Sumner, D.M., Jacobs, J.M., Pathak, C.S., Paech, S.J., and Douglas, E.M., 2011, Use of visible geostationary operational meteorological satellite imagery in mapping reference and potential evapotranspiration over Florida, chap. 10 of Labedzki, Leszek, ed., Evapotranspiration: Intech, p. 229-254 [Also available at http://www.intechopen.com/books/show/title/evapotranspiration.]

Metz, P.A., and Sacks, L.A., 2002, Comparison of hydrogeology and water quality of an augmented lake with two non-augmented lakes in northwest Hillsborough County, Florida: U.S. Geological Survey Water-Resources Investigations Report 02-4032, 74 p.

Miller, J.A., 1986, Hydrogeologic framework of the Floridan Aquifer System in Florida and in parts of Georgia, South Carolina, and Alabama: U.S. Geological Survey Professional Paper 1403-B, 91 p.

Miller, J.A., 1990, Ground water atlas of the United StatesSegment 6, Alabama, Florida, Georgia, and South Carolina: U.S. Geological Survey Hydrologic Investigations Atlas HA-730-G, 28 p.

Monroe, W.H., 1970, A glossary of karst terminology: U.S. Geological Survey Water Supply Paper 1988-K, 26 p.

National Oceanic and Atmospheric Administration, 2015a, Data tools-1981-2010 Normals: National Centers for Environmental Information, accessed January 20, 2016, at https://www.ncdc.noaa.gov/cdo-web/datatools/normals.
National Oceanic and Atmospheric Administration, 2015b, Monthly summaries data details: National Centers for Environmental Information, accessed January 20, 2016, at https://www.ncdc.noaa.gov/cdo-web/datasets/GHCNDMS/ stations/GHCND:USC00084289/detail.

National Oceanic and Atmospheric Administration, 2017a, 2006 Southwest Florida Water Management District (SWFWMD) Lidar: North District: accessed August 22, 2017, at https://data.noaa.gov/dataset/2006-southwest-florida-watermanagement-district-swfwmd-lidar-north-district.

New, Greg, 1980, ROMP site 113: Southwest Florida Water Management District Executive Summary, 4 p.

O'Reilly, A.M., 2007, Effects of the temporal variability of evapotranspiration on hydrologic simulation in central Florida: U.S. Geological Survey Scientific Investigations Report 2007-5100, 36 p.

Ortiz, A.G., 2008, Potentiometric surface of the Upper Floridan aquifer, west-central Florida, September 2007: U.S. Geological Survey Open-File Report 2008-1105, 1 sheet.

Patton, C.J., and Kryskalla, J.R., 2003, Methods of analysis by the U.S. Geological Survey National Water Quality Laboratory-Evaluation of alkaline persulfate digestion as an alternative to Kjeldahl digestion for determination of total and dissolved nitrogen and phosphorus in water: U.S. Geological Survey Water-Resources Investigations Report 03-4174, 33 p.

Plummer, L.N., and Friedman, L.C., 1999, Tracing and dating young groundwater: U.S. Geological Survey Fact Sheet 134-99, 4 p.

Romie, Kenneth, 2000, Water chemistry of lakes in the Southwest Florida Water Management District: Southwest Florida Water Management District Environmental Section, 124 p.

Rutledge, A.T., 1977, Hydrologic reconnaissance of Tsala Apopka Lake, Citrus County, Florida: U.S. Geological Survey Water-Resources Investigations Report 77-89, 1 map.

Sacks, L.A., 1996, Geochemical and isotopic composition of ground water with emphasis on sources of sulfate in the Upper Floridan aquifer in parts of Marion, Sumter, and Citrus Counties, Florida: U.S. Geological Survey WaterResources Investigations Report 95-4251, 47 p.

Sacks, L.A., 2002, Estimating ground-water inflow to lakes in central Florida using the isotope mass-balance approach: U.S. Geological Survey Water-Resources Investigations Report 02-4192, 59 p.

Sacks, L.A., Lee, T.M., and Swancar, A., 2014, The suitability of a simplified isotope-balance approach to quantify transient groundwater-lake interactions over a decade with climatic extremes: Journal of Hydrology, v. 519, p. 30423053. 
Schiffer, D.M., 1996, Hydrology of central Florida lakes-A primer: U.S. Geological Survey Open-File Report 96-412, $37 \mathrm{p}$.

Scott, T.M., 1988, The lithostratigraphy of the Hawthorn Group (Miocene) of Florida: Florida Geological Survey Bulletin No. 59, 148 p.

Sepulveda, Nicasio, 2002, Simulation of groundwater flow in the Intermediate and Floridan aquifer systems in peninsular Florida: U.S. Geological Survey Water-Resources Investigations Report 02-4009, 130 p.

Southwest Florida Water Management District, 1987, Groundwater resource availability inventory-Citrus County, Florida: Resource Management, Planning, and Resource Regulation Departments, 140 p.

Southwest Florida Water Management District, 2004, ROMP 116 Tsala Apopka Lake surficial monitor well addition: Southwest Florida Water Management District Executive Summary Addendum, 7 p.

Southwest Florida Water Management District, 2006, Aquifer characteristics within the Southwest Florida Water Management District (4th ed.): Southwest Florida Water Management District Report 99-1, 28 p., at http://www.swfwmd.state.fl.us/permits/wellconstruction/ aquifer_characteristics.pdf.

Southwest Florida Water Management District, 2007, Minimum and guidance levels for Tsala Apopka Lake in Citrus County, Florida: Southwest Florida Water Management District Ecologic Evaluation Section, 87 p.

Southwest Florida Water Management District, 2010, Operational guidelines for the Tsala-Apopka Chain of Lakes: no. 19-1, 4 p. [Also available at http://www.swfwmd. state.fl.us/files/database/site_file_sets/2269/Tsala-_Apopka_ Chain_of_Lakes[1].pdf.]

Southwest Florida Water Management District, 2011, Land use and management plan-Flying Eagle Preserve: Southwest Florida Water Management District, 27 p.

Southwest Florida Water Management District, 2014a, Withlacoochee River Watershed Initiative model development and verification report (H066): Orlando, Atkins Global, $157 \mathrm{p}$.

Southwest Florida Water Management District, 2014b, Water management information system: accessed September 29, 2014, at http://www18.swfwmd.state.fl.us/ResData/Search/ ExtDefault.aspx.

Southwest Florida Water Management District, 2015a, Regional water supply plan-Northern planning region: Southwest Florida Water Management District with the assistance of WadeTrim, $149 \mathrm{p}$.
Southwest Florida Water Management District, 2015b, Withlacoochee River Watershed Initiative model scenario report (H066): Orlando, Atkins Global, 153 p.

Southwest Florida Water Management District, 2017a, Index of Tsala Apopka structure flows from 2004 to 2013: accessed August 22, 2017, at http://ftp.swfwmd.state. fl.us/pub/GWIS/Tsala_Apopka_Structure_Flows_2004_ to_2013/.

Southwest Florida Water Management District, 2017b, Regional observation and monitor-well program (ROMP): accessed August 22, 2017, at https://www.swfwmd.state. fl.us/projects/romp/.

Southwest Florida Water Management District, 2017c, Historical groundwater and surface water levels, rainfall, and evapotranspiration data: accessed August 22, 2017, at http://www.swfwmd.state.fl.us/data/hydrologic/.

Southwest Florida Water Management District, 2017d, Index of radar rainfall: accessed August 22, 2017, at http://ftp.swfwmd.state.fl.us/pub/radar_rainfall/.

Southwest Florida Water Management District, 2017e, 2011 Land use land cover: accessed August 22, 2017, at http://data-swfwmd.opendata.arcgis.com/datasets/ f325a3417c92444d9cba838154d6fa0d_11.

Spencer, S.M., 1984, Geology of Citrus County, Florida: Florida Geological Survey Open-File Report 5, 18 p.

Stamm, J.F., and McBride, W.S., 2016, Sources of groundwater and characteristics of surface-water recharge at Bell, White, and Suwannee Springs, Florida, 2012-13: U.S. Geological Survey Open-File Report 2016-1190, 27 p. [Also available at https://doi.org/10.3133/ofr20161190.]

Stringfield, V.T., 1966, Artesian water in Tertiary limestone in the southeastern states: U.S. Geological Survey Professional Paper 517, $226 \mathrm{p}$.

Sumner, D.M., 2006, Adequacy of selected evapotranspiration approximations for hydrologic simulation: Journal of the American Water Resources Association, v. 42, no. 3, p. 699-711.

Sumner, D.M., 2017a, Evapotranspiration (ET) at Tiger Bay State Forest site, Volusia County, Florida, January 1, 1998December 31, 1999: U.S. Geological Survey data release, accessed September 16, 2017, at https://doi.org/10.5066/ F7SB447H.

Sumner, D.M., 2017b, Evapotranspiration (ET) at Lake Wales Ridge site, 20-minute data, Orange County, Florida, September 15, 1993-August 27, 1994: U.S. Geological Survey data release, accessed September 16, 2017, at https://doi.org/10.5066/F7PK0DN5. 
Sumner, D.M., Hinkle, C.R., and Becker, K.E., 2017, Evapotranspiration (ET) at University of Central Florida urban site, daily data, Orange County, Florida, January 29, 2009 September 27, 2012: U.S. Geological Survey data release, accessed September 16, 2017, at https://doi.org/10.5066/ F7JS9NZB.

Swancar, Amy, Lee, T.M., and O'Hare, T.M., 2000, Hydrogeologic setting, water budget, and preliminary analysis of ground-water exchange at Lake Starr, a seepage lake in Polk County, Florida: U.S. Geological Survey Water-Resources Investigations Report 00-4030, 65 p.

Trommer, J.T., Yobbi, D.K., and McBride, W.S., 2009, Surface- and groundwater interactions along the Withlacoochee River, west-central Florida: U.S. Geological Survey Scientific Investigations Report 2009-5124, 65 p.

U.S. Geological Survey, variously dated, National field manual for the collection of water-quality data: U.S. Geological Survey Techniques of Water-Resources Investigations, book 9, chap. A1-A9, [variously paged]. [Also available at http://water.usgs.gov/owq/FieldManual/.]

U.S. Geological Survey, 2017a, National Water Information System-Web interface: accessed March 22, 2017, at https://doi.org/10.5066/F7P55KJN.

U.S. Geological Survey, 2017b, Evapotranspiration information and data: accessed March 22, 2017, at https://fl.water.usgs.gov/et/.

Vernon, R.O., 1951, Geology of Citrus and Levy Counties, Florida: Florida Geological Survey Bulletin 33, 256 p.
Wharton, B.R., and Dooris, P.M., 2005, Lake Tsala Apopka Lake watershed presettlement surface water features and vegetation: Prepared by HDR for U.S. Army Corps of Engineers, $45 \mathrm{p}$.

White, William, 1958, Some geomorphic features of Central Peninsular Florida: Florida Geological Survey Geological Bulletin No. 41, 92 p.

White, William, 1970, The geomorphology of the Florida Peninsula: Florida Geological Survey Geological Bulletin No. 51, 164 p.

Williams, C.P., Burdette, K.E., Green, R.C., Bassett, S.W., Flor, A.D., and Paul, D.T., 2011, Text to accompany geologic map of the eastern portion of the USGS Inverness $30 \times 60$ minute quadrangle, central Florida: Florida Geological Survey Open-File Report 96, 40 p.

Williams, L.J., and Kuniansky, E.L., 2015, Revised hydrogeologic framework of the Floridan aquifer system in Florida and parts of Georgia, Alabama, and South Carolina: U.S. Geological Survey Professional Paper 1807, 140 p., 23 pls.

Winter, T.C., 1981, Uncertainties in estimating the water balance of lakes: Water Resources Bulletin, v. 17, no. 1, p. 82-115.

Winter, T.C., Harvey, J.W., Franke, O.L., and Alley, W.M., 1998, Ground water and surface water-A single resource: U.S. Geological Survey Circular 1139, 79 p. 


\section{Appendix 1. Detailed Description of Methods of Discharge Computation and Rating Development}

\section{Canal Flows and Water-Control Structure Ratings}

Discharge conditions were monitored from 2010 to 2014 at each of the following water-control structures with the intention of developing flow rating curves for each structure: Leslie Heifner, Floral City, Orange State culverts, Flying Eagle Berm culverts, Golf Course, Moccasin Slough, Bryant Slough, Brogden Bridge, Brogden Bridge culverts, Vann Ness, and S-353 (fig. 1-1). Flow did not occur through the Orange State culverts, Bryant Slough, and S-353 during the study period, so it was not possible to collect the discharge data necessary to develop ratings for these structures. No structure is present at Shinn Ditch, but flows were measured there and a rating curve was developed for the site.

Each structure is unique in construction and the flow through each structure is dependent on channel conditions upstream and downstream; therefore, it was necessary to use a variety of techniques to develop rating curves for each structure. Flow regimes were classified as free or submerged orifice and weir, depending on the tail-water level, gate opening, and headwater level. The criteria that define each regime and the corresponding flow equations are listed in table $1-1$ (Collins, 1977). Flow equations and characteristics were determined for each structure, and data associated with each structure, canal, and stream are available from Southwest Florida Water Management District (SWFWMD) at SWFWMD (2017). Discharge data collected by the U.S. Geological Survey (USGS) are available from the National Water Information System (U.S. Geological Survey, 2017).

Orifice flow is flow through a pipe, culvert, or gate in which water upstream fully submerges the orifice entrance. Orifice flow can further be classified as free or submerged orifice flow. Free orifice flow exists when water leaving a pipe or culvert falls freely to the water surface below; more specifically, it is defined as when the tail water is below the orifice invert (Franz and Melching, 1997). For free orifice flow, a flow coefficient was calculated for each discharge measurement using equation 1 in table 1-1 (Collins, 1977). The relationship between the free orifice flow coefficient ( $C$ in equation 1) and the vertical gate opening is determined using a least squares regression (hereinafter referred to as "regression"). Discharge can then be calculated for any free orifice flow condition using the flow coefficient determined from the regression equation and the measured gate opening, headwater level, and gate width.

If orifice flow conditions are present and the tailwater level referenced to the gate sill rises higher than the vertical gate opening, then submerged orifice flow exists. Using equation 2 in table $1-1$ and the measured discharge, a submerged orifice flow coefficient $\left(\mathrm{C}_{\mathrm{gs}}\right)$ can be calculated. The relation of the submerged orifice flow coefficient as a function of vertical gate opening $\left(h_{g}\right)$ is determined using a regression. For submerged culverts, such as the Flying Eagle Berm culverts, the area of water flowing through the culvert can be substituted into equation 2 for the static tail-water elevation and lateral width of the gate $\left(h_{3} B\right)$ terms. Another option for submerged orifice flow uses the total vertical gate opening of all gates (eq. 3) and the "square root of fall" $\left(\sqrt{ }\left(h_{1}-h_{3}\right)\right.$ across the structure to calculate discharge (eq. 4). The "square root of fall" term is commonly used in submerged weir flow ratings, and the total gate opening makes equation 4 applicable to orifice flow conditions. The term $\mathrm{C}_{\mathrm{TGO}}$ is a constant commonly assumed to be 1.0. A regression equation for discharge as a function of the "square root of fall" should produce a linear relationship.

In general, weir flow occurs when the water upstream from a structure does not submerge the opening. More specifically, when the structure gate opens at or above two-thirds the static headwater level referenced to the gate sill, the flow regime changes to weir flow. Free weir flow exists if the submergence ratio is less than the $R_{w}$ term, which is typically 0.6 (Collins, 1977). A free weir flow coefficient is calculated for each discharge measurement using equation 5 . The coefficients are then plotted as a function of the corresponding $h_{1}$ values, from which a regression can be developed. Flows can then be calculated for various headwater elevations using the coefficient produced from the regression equation. Another option for discharge calculation at a structure under free weir flow is the use of total static head (TSH). The total static head is the sum of the difference between headwater elevation and top of gate elevation for each gate (eq. 6). A regression equation of discharge as a function of total static head should produce a linear relationship.

If the tail-water elevation rises high enough, it can affect flow through the structure, and a different equation must be used for the discharge calculation. These submerged conditions occur under weir flow when the submergence ratio is greater than or equal to 0.6 (Collins, 1977). The free weir flow coefficient calculated in equation 5 is used in equation 7 (table 1-1), along with the measured discharge and other pertinent parameters, to calculate the submerged weir flow coefficient. A relationship is determined between the submerged weir flow coefficients as a function of submergence ratios using linear regression. If no free weir flow exists at a thin-plate weir structure, or equation 5 did not provide a favorable relationship from which to calculate a free weir flow coefficient, other methods for submerged weir flow should be investigated. For thin-plate weirs, it may be feasible to assume the free weir flow coefficient is constant at 1.0, and the submerged weir flow coefficient can 


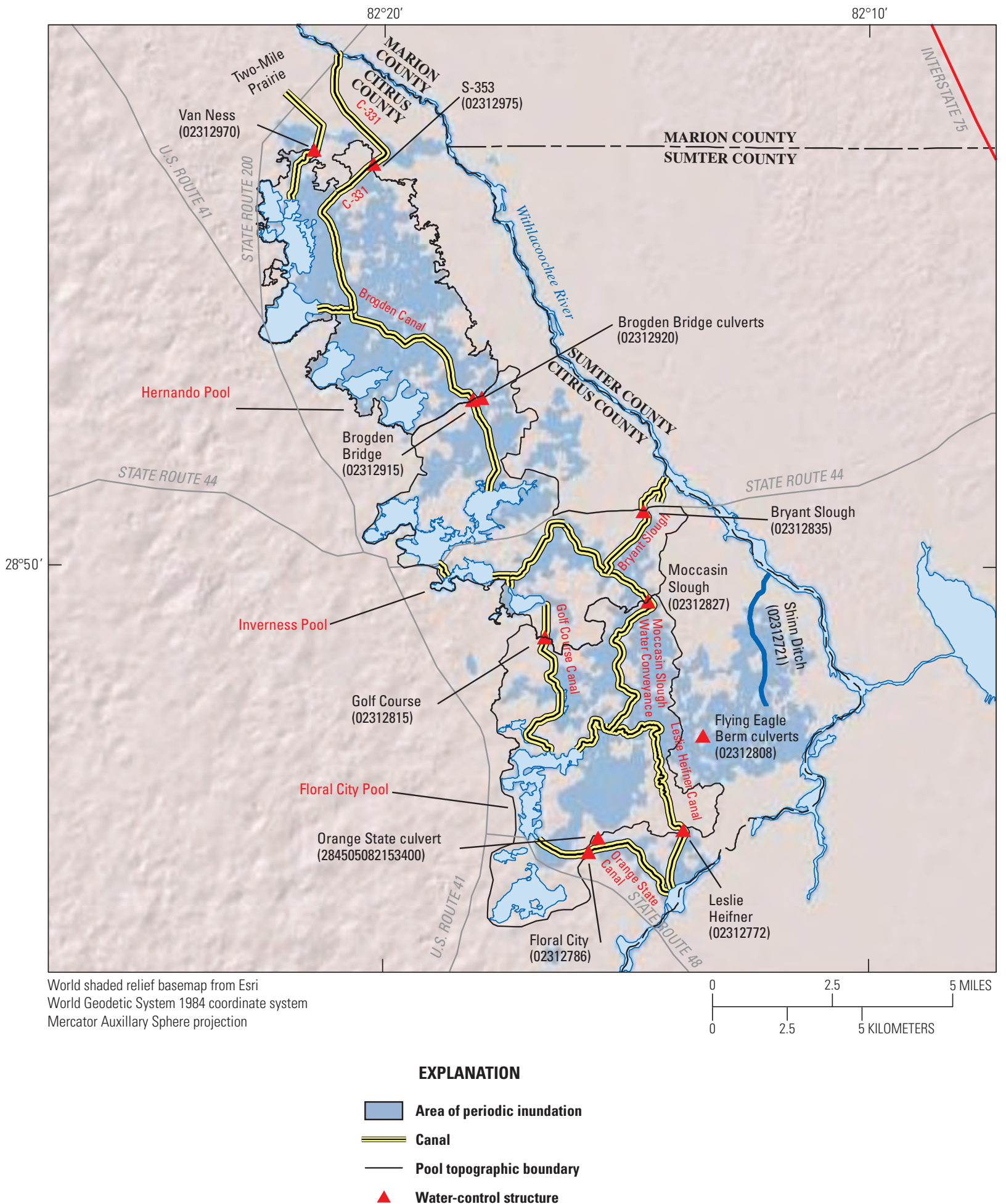

Figure 1-1. Location of the water-control structures and canals at Tsala Apopka Lake where discharge conditions were monitored from 2010 to 2014 
Table 1-1. Flow equations used to develop discharge ratings at the Tsala Apopka Lake water-control structures.

[ $B$, lateral width of gate, in feet; $C$, free orifice flow coefficient; $C_{g s}$, submerged orifice flow coefficient; $C_{T G O}$, total gate opening constant (usually 1.0), in feet to 1.5 power divided by seconds; $C_{w}$, free weir flow coefficient; $C_{W s}$, submerged weir flow coeffieient; $g$, acceleration of gravity, in feet per second per second; $h_{g}$, vertical gate opening, in feet; $h_{1}$, static headwater elevation, referenced to gate sill, culvert invert, or top of crest gates, in feet; $h_{3}$, static tailwater elevation referenced to gate sill, culvert invert, or top of crest gates, in feet; $\frac{h_{3}}{h_{1}}$, submergence ratio; $n$, number of gates in the control structure; $Q$, flow, or discharge, in cubic feet per second; $R_{w}$, value of submergence ratio (usually 0.6 ) above which submerged weir flow exists; TGO, sum of total vertical gate opening of all gates, in feet; $T S H$, sum of total static head over top of each gate, in feet]

\begin{tabular}{|c|c|c|c|}
\hline Equation number & Flow regime & Hydraulic conditions & Flow equations \\
\hline (1) & Free Orifice & $\begin{array}{l}h_{g}<\frac{2}{3} h_{1} \\
h_{3}<h_{g}\end{array}$ & $Q=C h_{g} B \sqrt{2 g h_{1}}$ \\
\hline (2) & \multirow{3}{*}{ Submerged Orifice } & \multirow{3}{*}{$\begin{array}{l}h_{g}<\frac{2}{3} h_{1} \\
h_{3} \geq h_{g}\end{array}$} & $Q=C_{g s} h_{3} B \sqrt{2 g\left(h_{1}-h_{3}\right)}$ \\
\hline (3) & & & $T G O=\sum_{i=1} h_{g_{i}}$ \\
\hline (4) & & & $Q=C_{T G O} T G O \sqrt{h_{1}-h_{3}}$ \\
\hline (5) & \multirow[b]{2}{*}{ Free Weir } & \multirow{2}{*}{$\begin{array}{l}h_{g} \geq \frac{2}{3} h_{1} \\
\frac{h_{3}}{h_{1}}<R_{w}\end{array}$} & $Q=C_{w} B h_{1}{ }^{3 / 2}$ \\
\hline (6) & & & $T S H=\sum_{i=1}^{n} h_{1_{i}}$ \\
\hline (7) & \multirow[b]{2}{*}{ Submerged Weir } & \multirow{2}{*}{$\begin{aligned} h_{g} & \geq \frac{2}{3} h_{1} \\
\frac{h_{3}}{h_{1}} & \geq R_{w}\end{aligned}$} & $Q=C_{w} C_{w s} B h_{1}^{3 / 2}$ \\
\hline (8) & & & $C_{w s}=\left[1-\left(\frac{h_{3}}{h_{1}}\right)^{3 / 2}\right]^{0.385}$ \\
\hline
\end{tabular}


then be calculated. A free weir flow coefficient can then be calculated using the submerged weir flow measurements, and the submerged weir flow coefficient can be calculated using the Villemonte equation (table 1-1, eq. 8). The Villemonte equation was developed in laboratory studies for submerged thin-plate weirs and provides a submerged weir coefficient for use in equation 7 (Villemonte, 1947). A relationship can then be determined between the calculated free weir flow coefficient for the submerged weir flow measurements and $h_{1}$ with a regression.

\section{Leslie Heifner Structure (USGS station number 02312772)}

The Leslie Heifner structure (fig. 1-1) is the main inlet to Tsala Apopka Lake. The canal branches from the Withlacoochee River and flows primarily northeast until it bends to the northwest approximately 300 feet (ft) upstream from the Leslie Heifner structure. The main channel merges with a secondary channel just downstream from the bend; the secondary channel only contributes at higher flows. Water flows through the structure and enters the Floral City Pool.

The structure consists of a steel sheet pile dam with a single vertical lift gate. The gate is usually either closed or fully open and clear of the water surface. In general, structure operations consist of opening the gate when the Withlacoochee River stage is higher than that of the Floral City Pool, allowing water to enter Tsala Apopka Lake. When the river stage drops below that of the lakes, the gate is closed to keep water in the lakes; therefore, Leslie Heifner canal connects two surface-water bodies with little fall across the structure. The real-time streamgage data can be referenced by the USGS station number 02312772 (table 1, SW16). Four discharge measurements by USGS were made from February 2011 to April 2011 with stage and gate opening data collected by SWFWMD. The USGS collected index-velocity and stage data beginning May 2011, and only the USGS data were used for rating development and real-time discharge computation through the structure. Discharge data (https://waterdata. usgs.gov/fl/nwis/measurements/?site_no=02312772) indicate that backflow occurred about 14 percent of the time from May 2011 to December 2013, such as in May 2011 and October 2012. The lack of fall across the structure and backflow led to the installation of an index velocity streamgage upstream of the structure and the use of index-velocity method (Levesque and Oberg, 2012) for discharge computation. This method uses a meter to measure one point velocity in the channel and surveying a cross section to relate stage to cross-sectional area of the channel.

The Leslie Heifner structure gate was fully opened each year of the study, and 27 discharge measurements were made by USGS personnel from May 2011 to February 2014 with the velocity equipment installed. The measured discharges covered multiple flow conditions, ranging from -21 to 238 cubic feet per second $\left(\mathrm{ft}^{3} / \mathrm{s}\right)$. Positive flow is defined as water flowing from the Withlacoochee River to Tsala Apopka Lake, and negative flow is defined as water flowing in the reverse direction. An index-velocity rating and stagearea rating were made using the index-velocity method with standard USGS procedures (Levesque and Oberg, 2012). The index-velocity rating was computed by way of two separate linear regressions, one each for the positive and negative measurements, and the stage-area rating was computed by way of a survey of the channel cross section in the reach of the streamgage (figs. 1-2A, B). The resultant index-velocity rating consists of a two-segment line with a smoothed transition near 0.00 foot per second (ft/s) (fig. 1-2A). One segment represents positive flow and the other represents negative flow. The different slopes in the two lines can be attributed to the orientation of the canal and the secondary channel. During positive flow, water enters the canal from the Withlacoochee River and, if high enough, from the secondary channel. The two channels merge upstream from the streamgage and structure, and the channel and structure opening serve as the control. During negative flow, water flows from the lakes through the structure and travels to the river. Under these conditions, control changes to the channel only, which splits into the main and secondary channels, so a different slope in the rating is expected.

The rating represents the canal and flow conditions well. The coefficient of determination for the positive portion of the index-velocity rating is 0.99 with a standard error of 0.025 , and a coefficient of determination of 0.96 with a standard error of 0.013 for the negative portion (errors are in terms of velocities, not discharge). Sixteen discharge measurements agreed with the discharges computed from the index velocity rating within plus or minus $( \pm) 7$ percent. The other higher percent differences can be misleading during low flow conditions. For example, one measurement in September 2011 plotted -34 percent off the rating, but was only low by $0.6 \mathrm{ft}^{3} / \mathrm{s}$ (fig. 1-2A). During flows with index velocities above $0.15 \mathrm{ft} / \mathrm{s}$, the channel represents a uniform flow distribution with stable velocities. The uniform distribution and channel geometry are ideal for the operation of an index-velocity streamgage.

Leakage through the structure was observed during the study period, and four discharge measurements were made with the gate closed. Although relatively insignificant $\left(-2.5\right.$ to $\left.-0.1 \mathrm{ft}^{3} / \mathrm{s}\right)$, the leakage measurements helped define the transition of the two segments of the rating, but scatter between the measured and rated discharge is expected at those very low flows.

Index velocities collected at Leslie Heifner canal ranged from -0.60 to $1.28 \mathrm{ft} / \mathrm{s}$ and streamgage heights ranged from 35.31 to $41.25 \mathrm{ft}$ during the period of study. Sharp fluctuations in index velocity of $0.2 \mathrm{ft} / \mathrm{s}$ or more in 15 -minute intervals occurred frequently (fig. 1-3A), which can be attributed to localized rainfall and (or) variable backwater conditions. Sharp decreases in velocity are most likely a result of heavy rainfall on the Floral City Pool downstream from the structure, which temporarily elevates the stage of the lake, whereas the Withlacoochee River remains unaffected. 

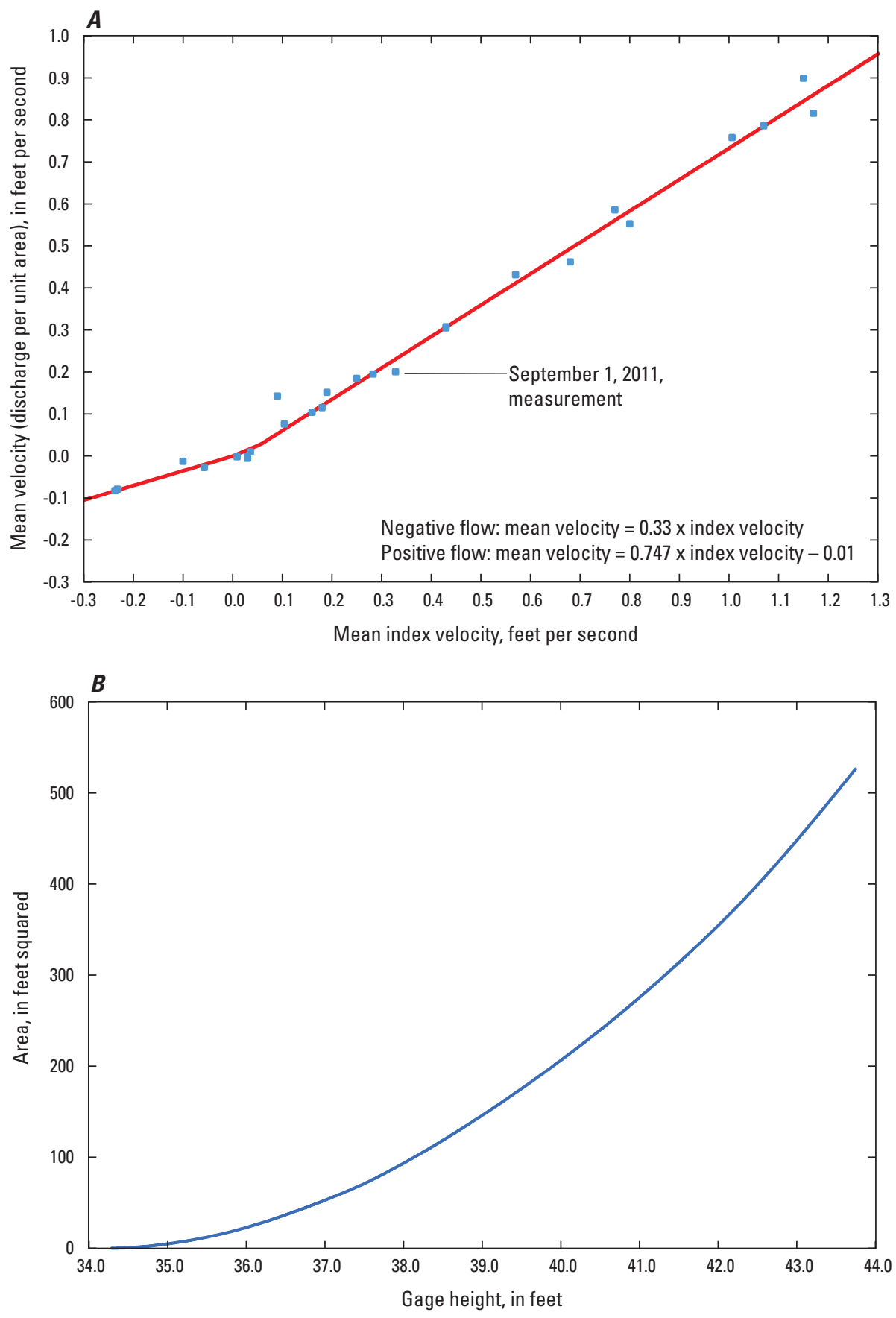

EXPLANATION

- Discharge measurement

Figure 1-2. Leslie Heifner structure $A$, index velocity and $B$, stage/area rating curve. 


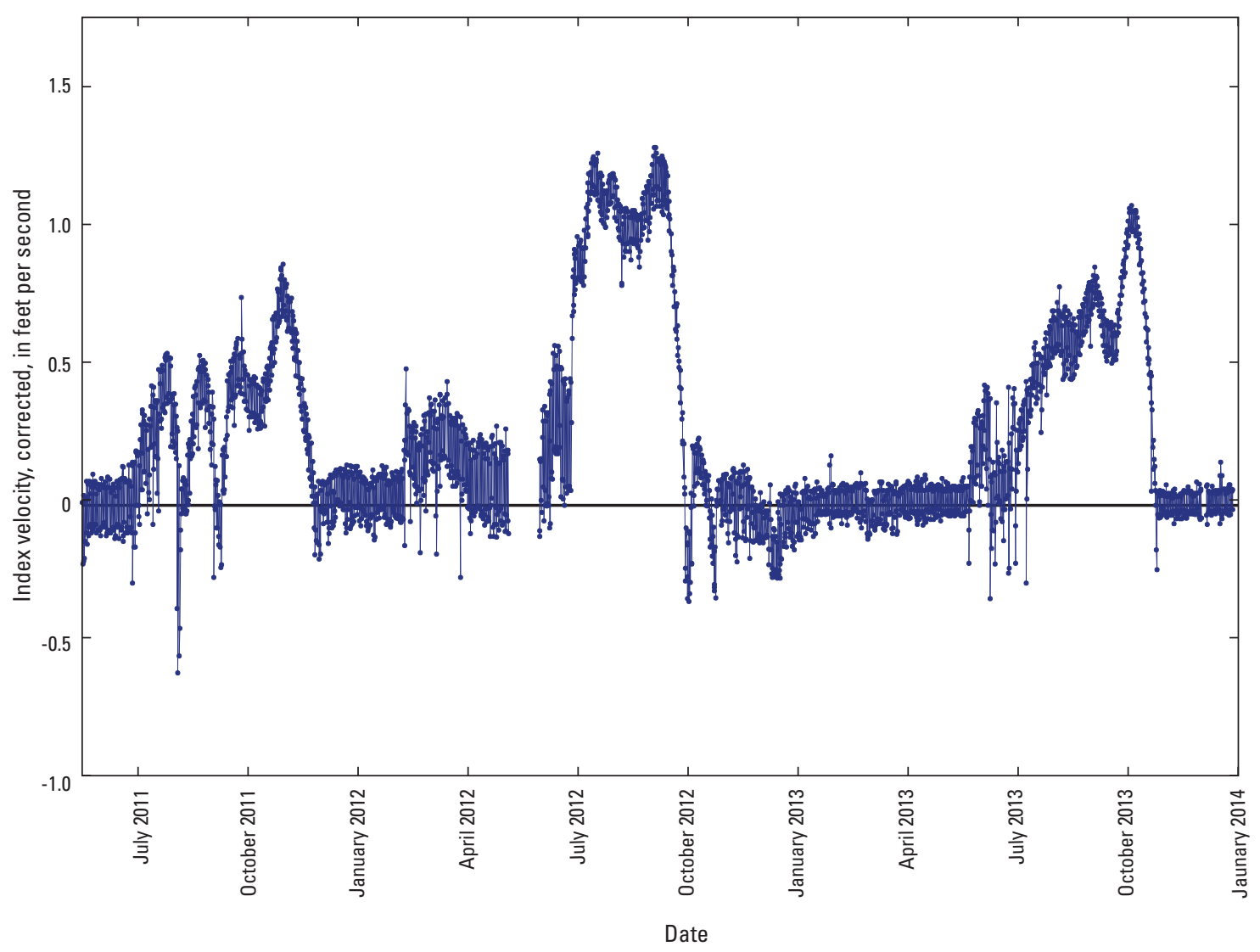

Figure 1-3. Fluctuations in index velocity at Leslie Heifner structure based on corrected 15-minute data measurements, May 2011-January 2014.

\section{Floral City Structure (USGS station number 02312786)}

The Floral City structure (fig. 1-1) is the second major inflow to Tsala Apopka Lake and diverts water from the Withlacoochee River. The canal runs primarily northwest from the river until 0.9 mile upstream from the Floral City structure, where it bends west. The canal runs west past the structure to the Floral City Pool, which is oriented primarily north-south.

The Floral City structure controls water through the Orange State canal (fig. 1-1) and consists of a single vertical lift gate with an invert elevation $3 \mathrm{ft}$ higher than that of the Leslie Heifner structure. The gate is usually either closed or fully open and clear of the water surface. In general, structure operations consist of opening the gate when the Withlacoochee River stage is higher than that of the Floral City Pool, allowing water to enter Tsala Apopka Lake. When the river stage drops below that of the lakes, the gate is closed to keep water in the lakes. Due to the higher invert elevation, free and submerged weir flow ratings were attempted, as well as a traditional stage/ discharge relationship. With increased backwater effects, neither of these procedures produced computed discharges that were representative of the measured flows. Therefore, a velocity meter was installed upstream from the structure and the index-velocity method for discharge computation was used. The real-time streamgage data can be referenced by the USGS station number 02312786 (SW19). The USGS collected index velocity and stage data beginning May 2013, and SWFWMD collected gate opening, upstream, and downstream stage data from February 2011 to February 2014. Only the USGS data were used for rating development and real-time discharge computation through the structure.

The Floral City structure gate was fully opened each year of the study, and 14 discharge measurements ranging from -10.8 to $130 \mathrm{ft}^{3} / \mathrm{s}$ were made by USGS personnel from February 2011 to April 2013. Traditional structure flow and stage/ discharge relationships could not be developed due to a large presence of backwater from the Floral City Pool (fig. 1-1), as indicated by the negative discharge measurements. For example, the highest discharge measurement of $130 \mathrm{ft}^{3} / \mathrm{s}$ only had $0.02 \mathrm{ft}$ of fall across the structure; therefore, computed discharges could not be produced during the study period without real-time records, continuous discharge measurements, and shifts for backwater. 
From May to December 2013, a velocity meter was installed upstream from the Floral City structure. Nine discharge measurements were made with the gate fully open during the study period with the velocity equipment installed. Leakage was not observed at the structure, and the measurements ranged from 0.44 to $62.5 \mathrm{ft}^{3} / \mathrm{s}$. An index-velocity rating was computed with a linear regression, and a stage-area rating was computed by way of a survey of the channel cross section in the reach of the streamgage using the index-velocity method and standard USGS procedures (Levesque and Oberg, 2012). The linear ratings (figs. 1-4A and B) show a good relationship between index velocity and discharge per unit area for the full range of measurements, as confirmed by the coefficient of determination of 0.99 and standard error of $0.06 \mathrm{ft}^{3} / \mathrm{s}$. Five of the nine measurements plotted within \pm 3 percent of the rated discharges and eight of the nine measurements plotted within \pm 13 percent. The highest percentage was a result of very low flow conditions because the measurement difference was only $0.14 \mathrm{ft}^{3} / \mathrm{s}$ from the rating.

The recorded index velocities ranged from -0.43 to $2.21 \mathrm{ft} / \mathrm{s}$ over the period of study (fig. 1-5). The index velocity record showed periods of sharp fluctuations, which can be attributed to localized rainfall either upstream or downstream from the site. Velocity fluctuations of $0.25 \mathrm{ft} / \mathrm{s}$ in 15 -minute intervals were common during summer months when heavy rainfall events occurred frequently. The rapid changes in velocities were verified by the jumps in streamgage height record, but the response was not always the same for each occurrence, which suggests that the location of the rainfall determines the discharge response. Rainfall on the Floral City Pool near the structure decreases discharge, whereas rainfall on the Withlacoochee River increases discharge, and both increase the streamgage height at the structure. This phenomenon hinders traditional stage/discharge or structure rating development, and index velocities provide an accurate parameter for discharge computation. Negative discharges were also computed for 2 days in late October 2013, after a recession from the peak earlier in the month. Water levels increased in the Floral City Pool from the positive discharges throughout the 4-month period and decreased in the Withlacoochee River due to the lack of rainfall, allowing negative flow until the structure gate was closed.

\section{Orange State Culvert (USGS station number 284505082153400)}

The Orange State culvert (fig. 1-1) is a secondary channel that branches from the Orange State canal approximately 0.3 mile upstream from the Floral City structure (SW19). The secondary channel is regulated by a culvert and gate operated by the SWFWMD. The Orange State culvert allows water to flow from the Withlacoochee River to the Floral City Pool, but its function as a conveyance is limited by tail-water conditions and debris problems. The channel contributed no flow through the Orange State culvert to Tsala Apopka Lake during the period of study (Mike Bartlett, SWFWMD, oral commun(s).,
2010-13), either because it was dry or the culvert gate was closed, and no discharge was measured by USGS personnel.

\section{Flying Eagle Berm Culverts (USGS station number 02312808)}

The Flying Eagle Berm culverts (fig. 1-1), approximately 2 miles north of the Leslie Heifner structure (SW16), indirectly connect the Floral City Pool and the Withlacoochee River. The site consists of 10 corrugated metal culverts with a wooden slide gate on the east (upstream) side of each culvert. The culverts allow water to pass under a berm dike road into the Floral City Pool if the stage in the river allows. Water does not directly enter from the river, but rather from approximately 2 miles of swamp and marsh, and no channelized canal exists like the other two inflows of Leslie Heifner canal and Orange State canal. The culverts can also be used to discharge water from the Floral City Pool to the Withlacoochee River if a positive head exists towards the river. Positive flow for this site is defined as flow from the Withlacoochee River to the Floral City Pool.

The culvert gates were only opened one time during the period of study, with 6 of the 10 culvert gates open. Three discharge measurements were made in August and September 2012 by USGS personnel during this 1-month period, and stage in the Floral City Pool (fig. 1-1) was higher than that of the river, so reverse flow was measured. Each discharge measurement consisted of one point velocity inside the center of the culvert, which is then multiplied by the cross-sectional area of water in the culvert. The total discharge for the site is the sum of individual discharges through each culvert. The measured discharges ranged from -5.2 to $-20.4 \mathrm{ft}^{3} / \mathrm{s}$ with a difference in stage of $0.63 \mathrm{ft}$. The SWFWMD collected headwater stage and tail-water stage data, which were used to compute the discharge rating for the structure culverts.

Regression was used to develop a rating curve of flow coefficient as a function of tail-water elevation referenced to the culvert invert (fig. 1-6), using a modified form of equation 2 (table 1-1). Tail-water elevation was used in the regression instead of gate opening due to the submergence of the culvert and fully opened gate. The cross-sectional area of water flowing through the six open culverts was substituted in the equation for $h_{3} B$ (static tail-water elevation times width of gate) for the calculation of the orifice flow coefficient. Essentially, it is an average coefficient for the culverts; they were not evaluated individually. The regression fits the discharge measurements with a coefficient of determination of 0.80 , and the computed discharge percent differences range from +8.9 to -10.6 percent; however, the small number of measurements (three in August and September 2012) reduces certainty in the rating curve. More measurements are needed to define the relationship outside the range of measured stages and with all culvert gates opened. The culverts were not open at any other times during the period of study, so no relationship could be made with positive discharge through the culverts. 

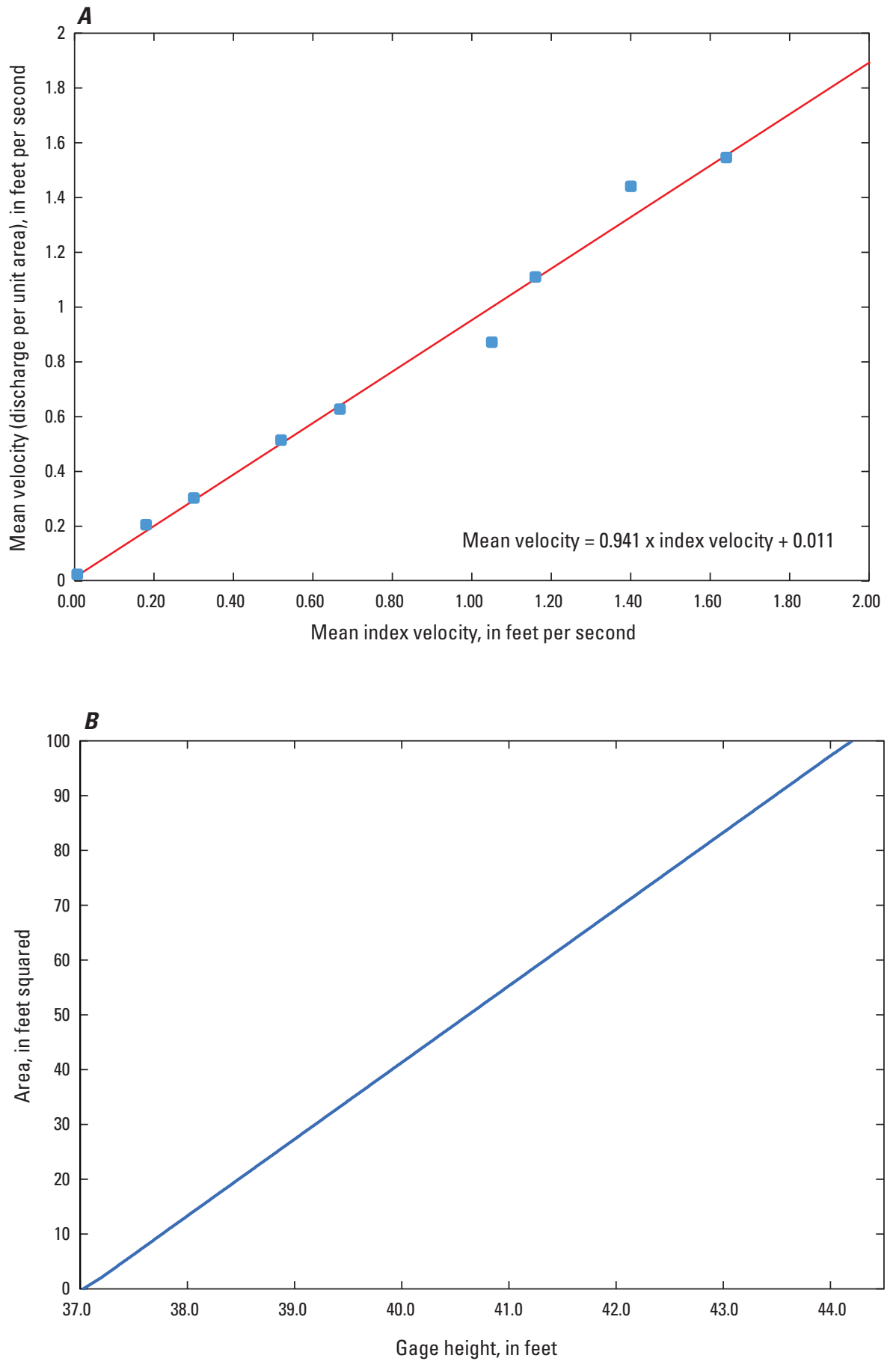

EXPLANATION

- Discharge measurement

Figure 1-4. Floral City structure $A$, index velocity and $B$, stage/area rating curve. 


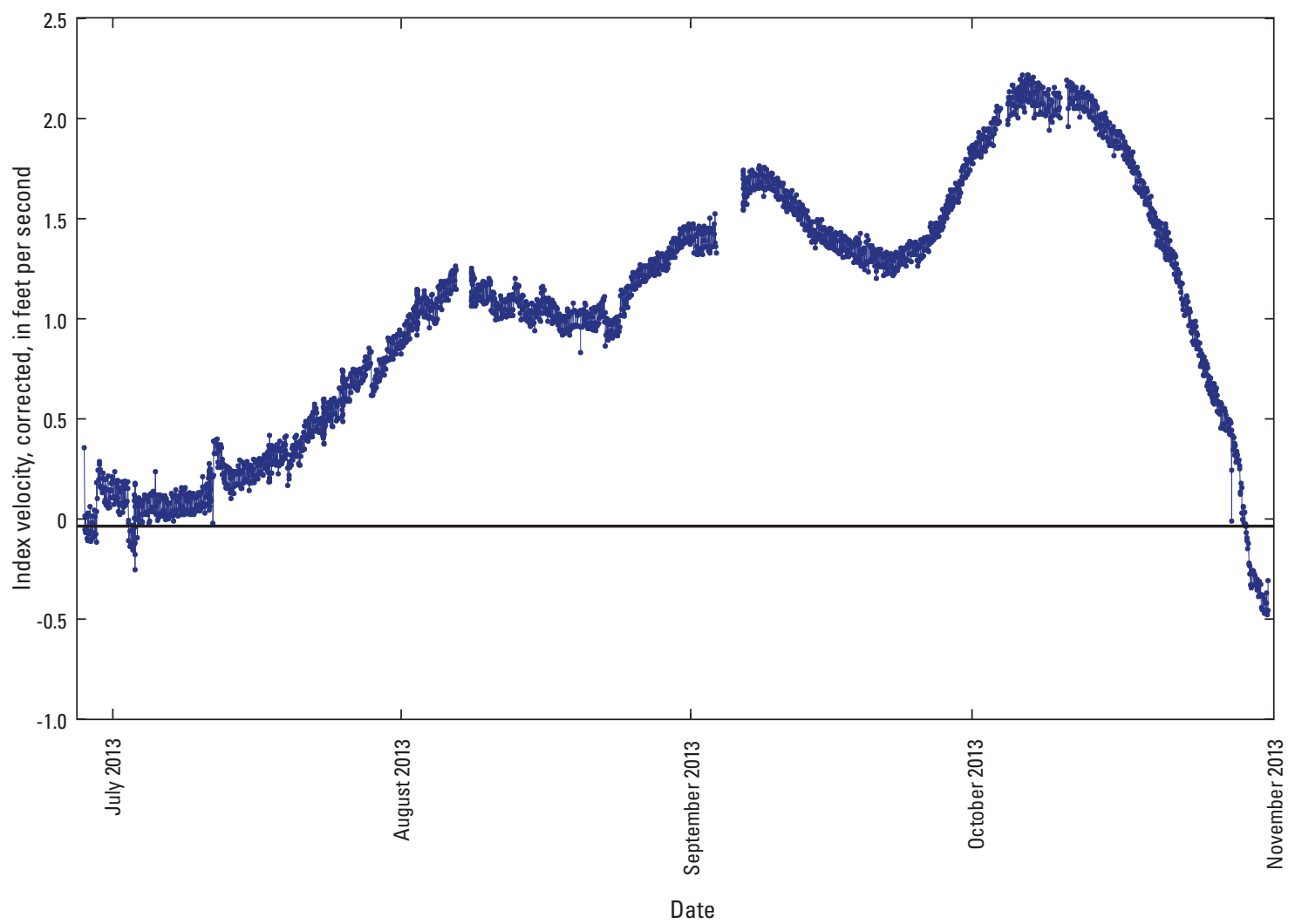

Figure 1-5. Fluctuations in index velocity at Floral City structure based on corrected 15-minute data measurements, May-November 2013.

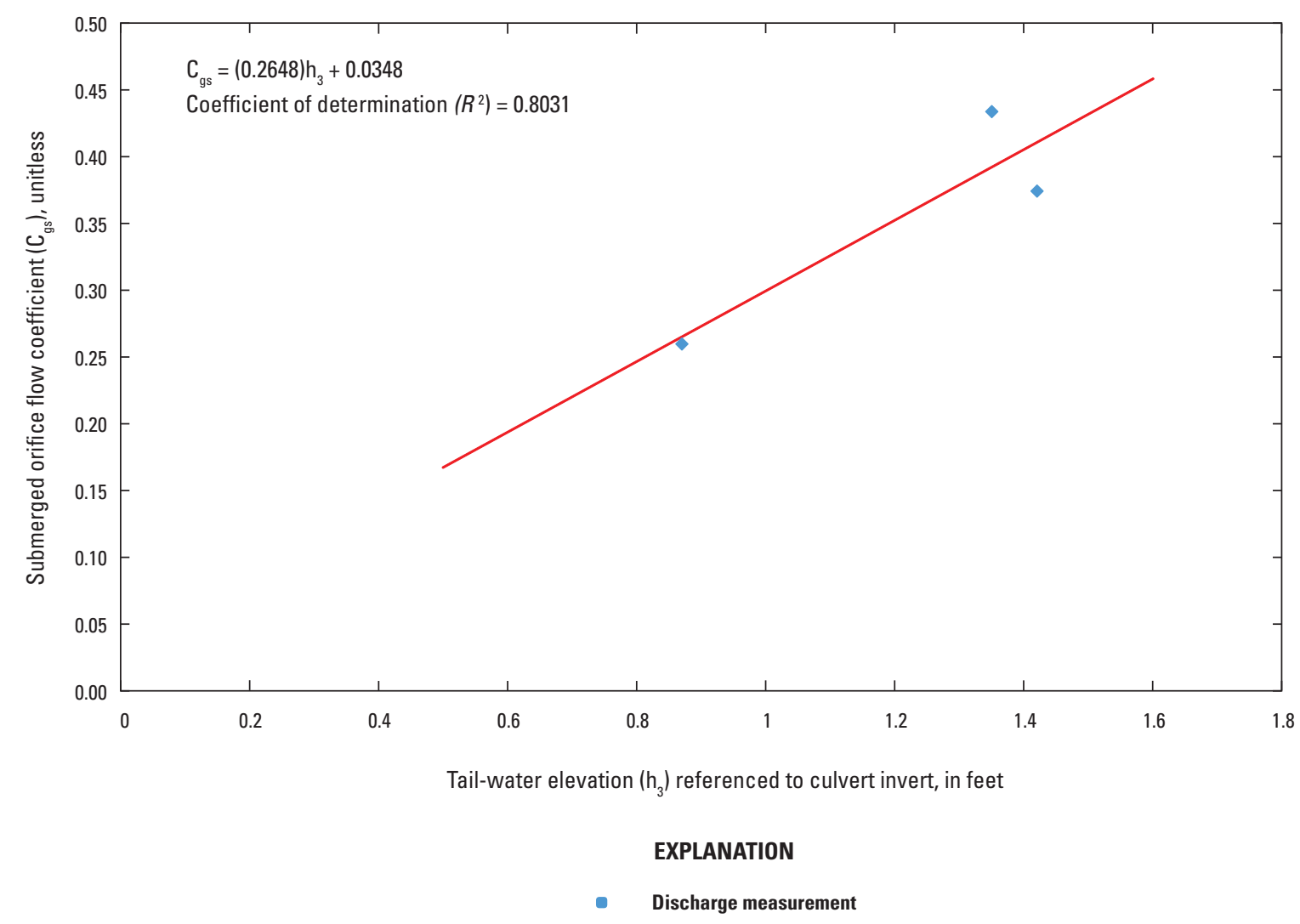

Figure 1-6. Least squares regression rating curve for the Flying Eagle Berm culverts (reverse flow only). See equation 2 in table 1-1 for the submerged orifice flow coefficient. 


\section{Shinn Ditch (USGS station number 02312721)}

Shinn Ditch (fig. 1-1) is an outlet from the Floral City Pool to the Withlacoochee River. Located on the northeast side of the pool, Shinn Ditch consists of a small, unregulated shallow canal that flows through the vegetated swamps. Flow through Shinn Ditch is affected by vegetation, downfall, and debris that change from season to season. A gravel road bed approximately 0.25 mile upstream from the data collection site acts as the retaining berm in the vicinity of the gage for the Floral City Pool. Flow was confined to the channel for all measurements during the study period.

Discharge measurements at Shinn Ditch, collected by USGS in 2012-13, were used to establish a stage-discharge rating (fig. 1-7), as a function of streamgage height. The stage-discharge rating for Shinn Ditch consists of two segments due to the low water control of sand and debris downstream from the streamgage. The slope of rating curve decreases when stage is above $37.0 \mathrm{ft}$, at which point the low water control is drowned out by the channel. Eight discharge measurements were made by USGS personnel from June 2012 to September 2013 with a range in stage from 35.97 to $37.54 \mathrm{ft}$ and in discharge from 3.2 to $35.4 \mathrm{ft}^{3} / \mathrm{s}$. Two measurements verified the upper end of the rating within \pm 9 percent. One measurement in September 2013 plotted -63 percent off the rating (fig. 1-7) due to substantial backwater effect from the Withlacoochee River and debris and downed trees in the channel downstream from the streamgage. Measurements in the range of the low water control with no backwater conditions checked the rating at \pm 9 percent, and three measurements plot within \pm 2 percent, which is considered an acceptable representation of the measurements made at the site under nonbackwater conditions given the many variables that affect flow through the small channel.

\section{Golf Course Structure (USGS station number 02312815)}

The Golf Course structure (fig. 1-1) separates the Floral City Pool from the Inverness Pool and consists of four steel vertical drop crest gates. A fixed sheet pile weir connects to the structure and extends into each bank. Four downward opening vertical lift gates, when open, allow water to flow over the top, acting as a thin-plate weir. A fairly straight man-made canal leads from the Floral City Pool to the structure, and a

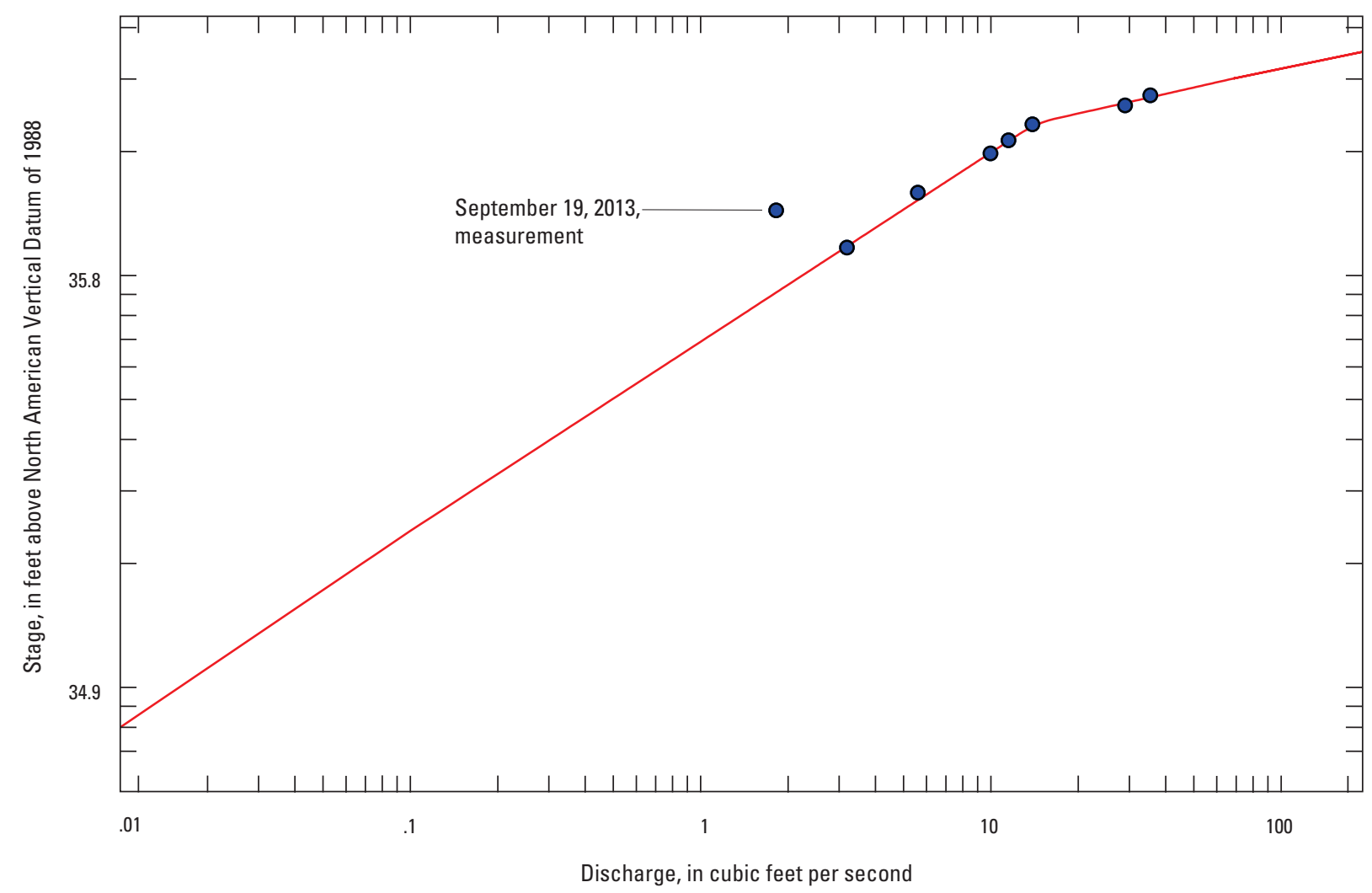

EXPLANATION

O Discharge measurement

Figure 1-7. Stage/discharge rating curve for Shinn Ditch. 
canal that leads away from the structure on the left bank and an overflow marsh make up the tail water. The SWFWMD collected gate opening, headwater stage, and tail-water stage data, which were used to compute flow ratings for the structure. Water flow through the Golf Course structure is restricted by its relatively high gate elevation of approximately $37.37 \mathrm{ft}$ with the gates fully opened (elevation average of all four gates), which is slightly higher than the invert elevation at the Floral City structure (fig. 1-1) and approximately $3 \mathrm{ft}$ higher than that of the Leslie Heifner structure, both upstream from the Floral City Pool. Therefore, water can enter the pool by way of Leslie Heifner canal but cannot exit until the stages rise above the higher elevation of the fully opened gates at the Golf Course structure, which limits the flow distribution capability to achieve the goal of passing two-thirds of the water from the Floral City Pool to the Inverness Pool during low or moderate flow periods (SWFWMD, 2010).

Twenty discharge measurements were made at the Golf Course structure by USGS personnel from April 2011 to September 2012 with flow possible over the top of the open gates in the fully down position. The measured discharges ranged from 3.6 to $184 \mathrm{ft}^{3} / \mathrm{s}$, and no leakage through the structure was observed or measured (fig. 1-8B). The water elevation was below the top of the fixed sheet pile weir on both sides of the structure gates during the entire period of study, so the only water that passed the structure flowed through the gates. All four gates were set at the same opening for all measurements, so all gates were evaluated together; ratings were not made for individual gates. All measurements were made under weir flow conditions, and submergence was determined by the evaluation of submergence ratio as defined by table $1-1$. Water flow through the structure was not completely perpendicular to the gates. Rather, it angled due to the approach channel shape and structure orientation, and the flow angle was more pronounced with higher flows.

Debris also affected discharge over the structure. Most of the vegetation in the canal floated on the surface, which lodged between the gates or on the edges and blocked flow through the cross-sectional area of gate opening. Debris was cleared before the measurements when possible, but large amounts of debris that could not be cleared existed for some measurements. The measurements affected by debris lodged on the structure were not used in rating development because the rating was drawn for clear control conditions. As expected, all of the debris-affected measurements plotted very low of the rated discharges due to smaller cross-sectional area available for flow.

Nine measurements were made under free weir flow conditions, and the rating function was based on equation 5 (table 1-1). Three of those measurements were affected by debris and not used for rating development. Neglecting the three measurements affected by debris, the plot of $C_{w}$ as a function of static head $\left(h_{1}\right)$ yields a linear relationship with a coefficient of determination of 0.89 . The relatively high value is misleading because the final discharge percent differences between the discharge measurements and rated discharges range from -22 to 18 percent, with only two measurements at 10 percent or less.

A linear relationship was also produced using discharge as a function of total static head (TSH) for the six free weir flow measurements not affected by debris (fig. 1-8A). The measured discharges verify the rated discharges between -14 and 9 percent, with four of the six measurements at less than \pm 7 percent, and a coefficient of determination of 0.90 with a standard error of 6.8. This relationship has better fit than the traditional free weir method using equation 5, most likely due to the nonperpendicular orientation of the approach channel to the structure.

Eleven discharge measurements were made under submerged weir flow conditions (fig. 1-8B). Three of those measurements were affected by debris and not used for rating development purposes. A "true" free weir flow coefficient $\left(C_{w}\right)$ was not calculated due to the use of total static head for free weir flow, so the Villemonte equation (table 1-1, eq. 8) was used for the submerged weir flow coefficient $\left(C_{w s}\right)$ calculation and a separate free weir coefficient was calculated using the submerged weir flow measurements, as described in the "Methods" section. The relationship of $C_{w}$ as a function of $h_{1}$ is linear and provides final discharge percent differences within less than \pm 6 percent for measurements not affected by debris, with a coefficient of determination of 0.87 and standard error of 0.20 for the coefficient relationship. The measurements affected by debris produced discharges that were 11-30 percent lower than the corresponding rated discharges.

\section{Moccasin Slough Structure (USGS station number 02312827)}

The Moccasin Slough structure (fig. 1-1) separates the Floral City Pool from the Inverness Pool. The structure regulates water through a canal that flows through cypress swamps above and below the structure. The structure consists of a single, vertical downward opening gate and two fixed weirs. The historic natural control elevation in Moccasin Slough between the Floral City and Inverness Pools is $39.20 \mathrm{ft}$. In general, the structure is fully opened (gate opened to its fullest position) at water levels below $39.20 \mathrm{ft}$ to allow normal movement of water in the immediate vicinity of the structure (SWFWMD, 2010). The SWFWMD collected gate opening, headwater stage, and tail-water stage data, which were used in the development of the discharge rating.

Due to limited fall across the structure, traditional weir flow equations were not used in rating development. Instead, the structure and channel were both treated as controls, and a stage-discharge relationship was developed (fig. 1-9). Twelve discharge measurements were made at Moccasin Slough structure by USGS personnel from June 2011 to October 2013 with water flowing over top of the opened structure gate, ranging from 0.4 to $122 \mathrm{ft}^{3} / \mathrm{s}$. Flow was not observed through the two fixed weirs during the period of study. A stage-discharge rating 

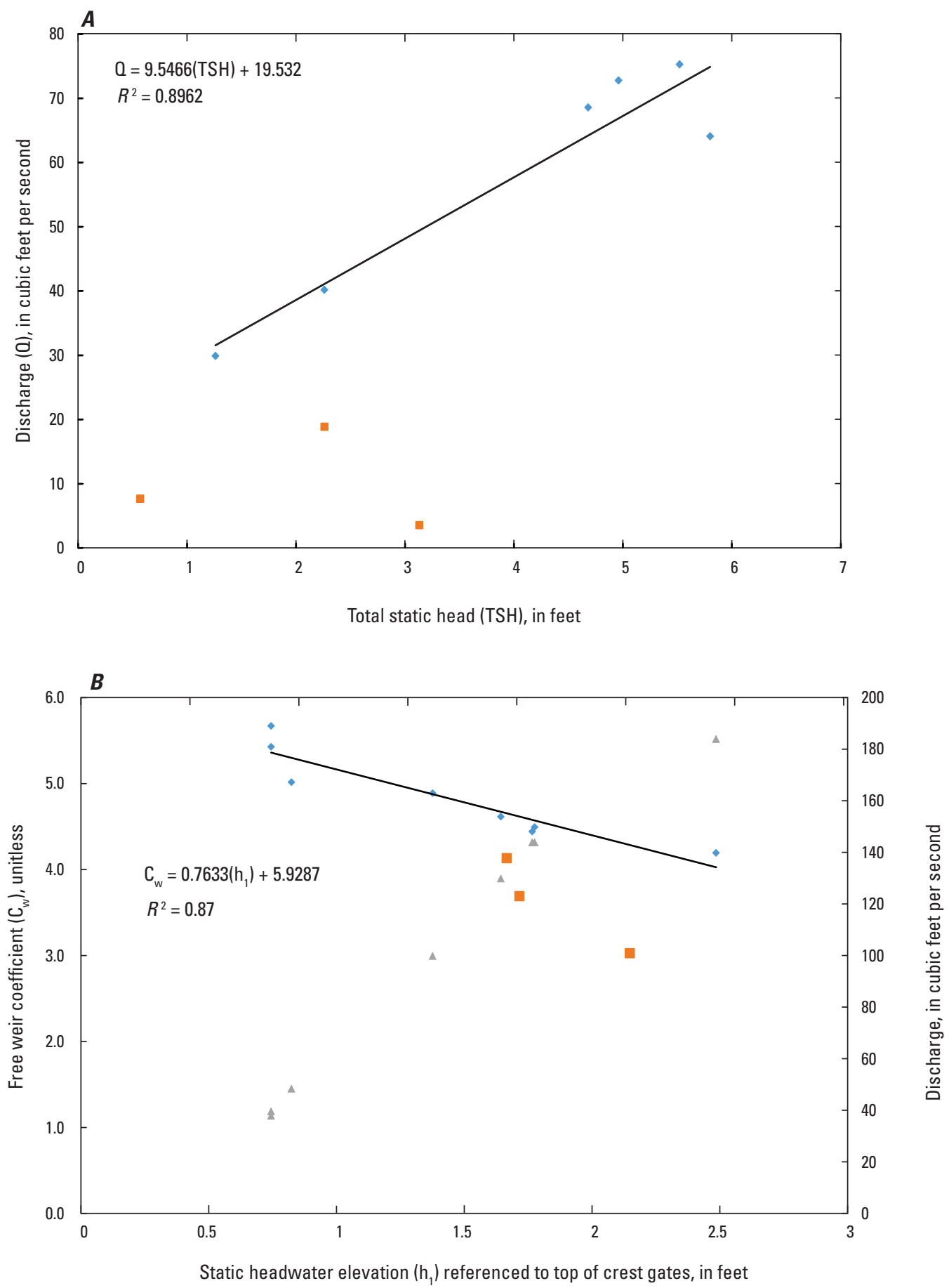

EXPLANATION

- Measurement used in rating

- Measurement not used in rating

$\triangle$ Measured discharge

Figure 1-8. Golf Course structure $A$, free weir and $B$, submerged-weir discharge rating curves. See equation 5 in table $1-1$ for the free-weir orifice coefficient. 


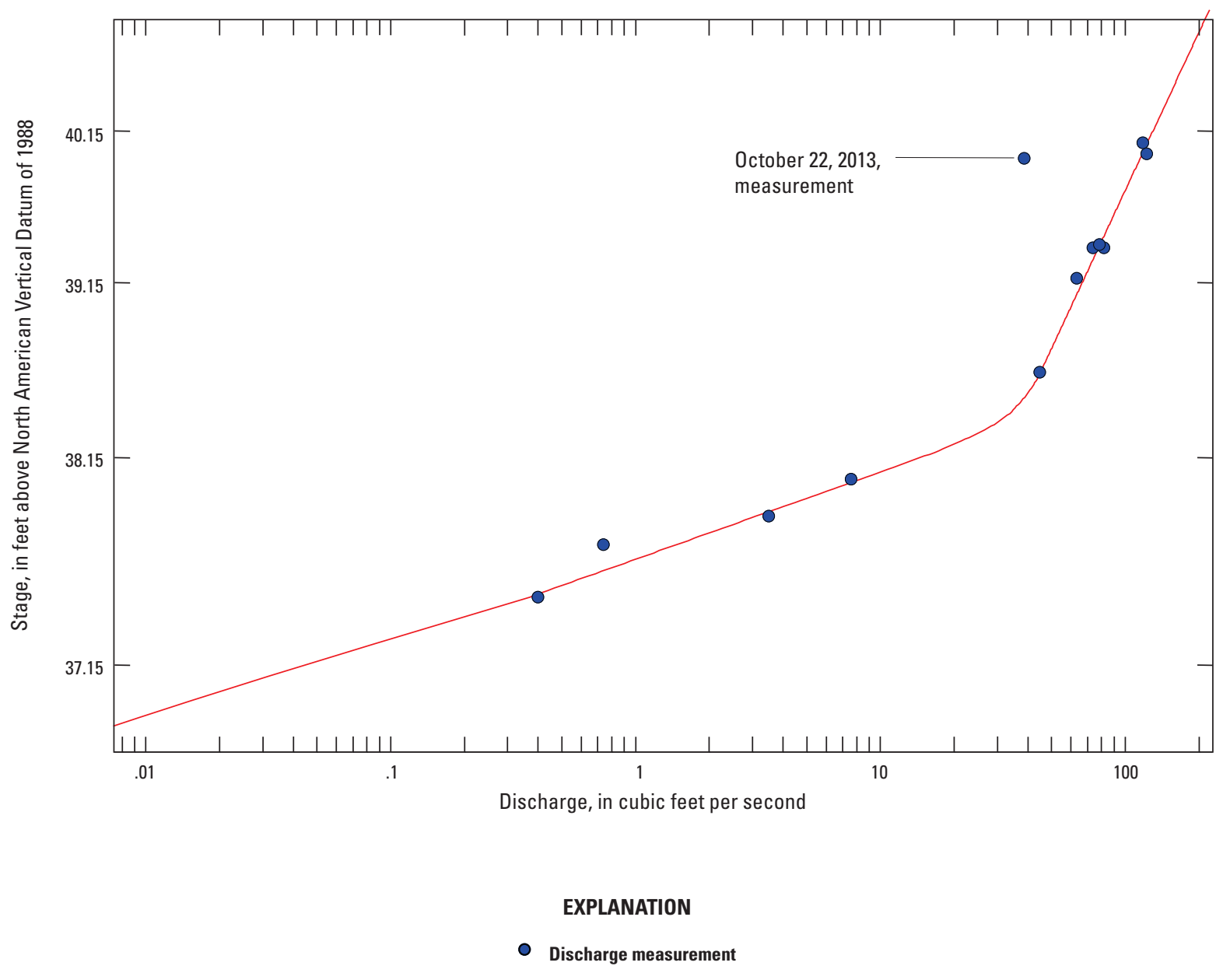

Figure 1-9. Stage/discharge rating curve for Moccasin Slough structure.

for nonbackwater conditions was created using the headwater streamgage height and discharge measurements made in 2011 and 2012. The rating consists of two linear segments that transition between 10 and $40 \mathrm{ft}^{3} / \mathrm{s}$. The lower segment is characterized by a flat slope for measurements below $10 \mathrm{ft}^{3} / \mathrm{s}$ with little fall across the structure. Tail-water conditions affect the structure control at these low flows, causing scatter around the rating. The mid- to high flow measurements above $40 \mathrm{ft}^{3} / \mathrm{s}$ all plot on a line with increased slope. These measurements were made with considerable fall across the structure, indicating the structure becomes the main control at higher flows. Discharge measurements in this portion all plotted within \pm 7 percent of the rating curve.

High flows occurred in 2012 and the tail-water elevation remained elevated during the winter dry season. The higher tail-water elevation made backwater conditions more pronounced. The structure gate was closed for most of 2013, and only one discharge measurement was made with the structure gate open in October. The measurement plotted -66 percent off the rating curve (fig. 1-9), confirming the backwater conditions. Backwater conditions exist at this site due to the cypress swamps surrounding the structure and control of the Inverness Pool.

In general, the Golf Course structure has a greater capacity to move water to the Inverness Pool than Moccasin Slough (fig. 1-1). An average of the highest flow measurements made in 2012 indicates that Golf Course passed $184 \mathrm{ft}^{3} / \mathrm{s}$, compared to $120 \mathrm{ft}^{3} / \mathrm{s}$ through Moccasin Slough, even though Moccasin Slough has an invert elevation $0.4 \mathrm{ft}$ lower. The higher flows through Golf Course can be attributed to the more desirable tail-water conditions, and the total width of all gates being more than 1.5 times the width of the gate at Moccasin Slough.

\section{Bryant Slough Structure (USGS station number 02312835)}

The Bryant Slough structure (fig. 1-1) discharges water from the east side of the Inverness Pool to the Withlacoochee River. The structure is mainly used to remove water from 
the pool during high water conditions or to create flood storage in anticipation of tropical storm or hurricane landfall (SWFWMD, 2010). These conditions and storage needs did not occur during the study period and the structure gates remained closed. No discharge measurements were made during the study period by USGS personnel.

\section{Brogden Bridge Structure (USGS station number 02312915)}

The Brogden Bridge structure (fig. 1-1) separates the Inverness Pool from the Hernando Pool and consists of two steel vertical lift gates. A steel sheet pile weir connects to the structure and extends into each bank. A straight man-made canal carries water into and out of the structure.

Sixteen discharge measurements were made at Brogden Bridge structure by USGS personnel from April 2011 to February 2014. No discharge was observed with a headwater elevation high enough to flow over the fixed sheet pile weir on either end of the structure. All measurements were made under submerged conditions, as determined by the equations in table 1-1 for weir or orifice flow. The SWFWMD collected gate opening, headwater stage, and tail-water stage data, which were used in the development of the discharge ratings.

Three discharge measurements were made with submerged weir flow (fig. 1-10A), covering a discharge range from 60 to $140 \mathrm{ft}^{3} / \mathrm{s}$. Because only submerged weir flow was measured, the free weir coefficient $\left(C_{w}\right)$ was assumed to be constant and equal to 1.0, dropping this term from the submerged weir flow equation (table 1-1, eq. 7). With only three points, the regression has a linear relationship and computed discharges ranged from -4 to 6 percent from the measured discharges, but more in-depth statistical analysis could not be performed with only three measurements. There was a small range of submergence ratios $\left(h_{3} / h_{1}\right)$ over the three measurements, but the range of headwater and tail-water stages was $0.6 \mathrm{ft}$, indicating that the headwater and tail water rose at the same rate over a wide range of submerged weir flows.

Fourteen discharge measurements were made under submerged orifice conditions (fig. 1-10B), which ranged from 3 to $86 \mathrm{ft}^{3} / \mathrm{s}$. One measurement was an outlier not used in rating curve calibration, indicating inaccurate data logged by the sensors. Submerged orifice discharge was calculated using equations 2 and 4 (table 1-1) for comparison. Both calculations show a different relationship by grouping measurements made in 2011 and 2012 and those made in 2013. The SWFWMD conveyed there were no major changes made to the structure during the period of study, so the environmental conditions were examined. The dry seasons of 2011 and 2012 were characterized by relatively low water levels in the Inverness and Hernando Pools (fig. 1-1), specifically with headwater elevations at Brogden Bridge structure below $37.20 \mathrm{ft}$. Extreme flows were measured in 2012, which raised the pool elevations higher than previous years. The water remained elevated throughout the dry season, and all measurements in 2013 were made with headwater elevations above $38.0 \mathrm{ft}$. There was also greater fall across the structure for the measurements made late in 2013 after rainfall increased on the watershed, more than in the previous years. Therefore, two ratings were made for submerged orifice discharge computation (fig. 1-10A) through Brogden Bridge: one for periods with headwater stages below $37.20 \mathrm{ft}$ using submerged orifice measurements from 2011 and 2012, and a second rating for periods with headwater stages above $37.20 \mathrm{ft}$, using only submerged orifice measurements from 2013 (fig. 1-10B).

The submerged orifice discharge calculation based on equation 2 (table 1-1, fig. 1-10B) produced a coefficient of determination of 0.99 for the measurements from 2011 and 2012. The coefficient of determination was calculated for the relationship of submerged orifice flow coefficient $\left(C_{g s}\right)$ as a function of submergence ratio $\left(h_{3} / h_{9}\right)$, not discharge. The calculated discharges from equation 2 were within \pm 10 percent of measured values, with five of the seven within \pm 7 percent of measured values. Equation 4 (table 1-1) was used to create a rating for the 2011 and 2012 measurements and also resulted in a coefficient of determination of 0.99 . Six of the seven measurements plotted within \pm 7 percent, and four of those measurements plotted within \pm 2 percent. To get an exact comparison between the two relationships, a linear regression was developed using calculated discharge from the rating and measured discharge. The calculation method using equation 2 produced a total sum of squared error of 410 (units: cubic feet per second squared) and the rating from equation 4 produced a total sum of squared error of 340 (units: square of cubic feet per second) for the 2011-12 measurements. The high coefficient of determination and 17 percent lower sum of squared error indicates a tighter fit of the measurements to the rating using equation 4 , so it was selected as the calculation method.

The six measurements from 2013 with a headwater stage above $37.20 \mathrm{ft}$ had more error for both surrogates than the previous set of measurements. All six measurements using equation 2 (table 1-1) plotted within \pm 12 percent of the rated discharges, with two within \pm 4 percent. The regression had a coefficient of determination of 0.96 . Using equation 4 (table 1-1), five of the six measurements plotted within \pm 11 percent, with two within \pm 5 percent. The regression had a coefficient of determination of 0.99 . A linear regression was also performed with the calculated discharges from the two equations and measured discharges. The discharges calculated using equation 2 produced a total sum of squared error of 3,130 (units: square of cubic feet per second) and equation 4 produced a total sum of squared error of 3,245 (units: square of cubic feet per second). The sums of squared error are much larger than the previous comparison because the measurements made in 2013 have higher discharges. Thus, the two errors in the evaluation of a rating for 2013 are similar (3.5-percent difference in sum of squared error), and the discharges were computed using equation 4 rather than equation 2 . 

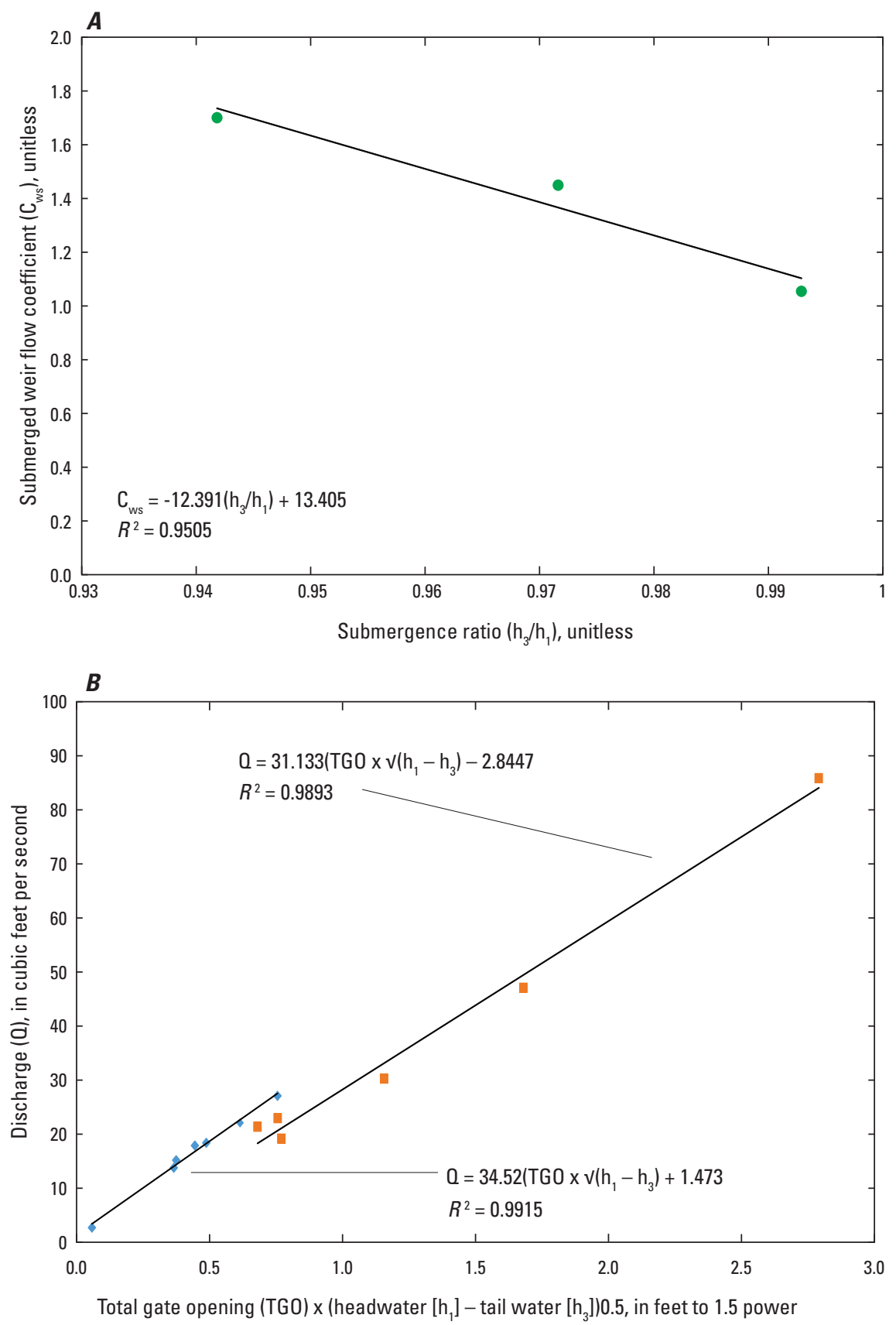

EXPLANATION

- Discharge measurements with submerged weir flow

- 2011-12 discharge measurements used in submerged orifice calculations

- 2013 discharge measurements used in submerged orifice calculations

Figure 1-10. Brogden Bridge structure discharge ratings for $A$, submerged weir and $B$, submerged-orifice for headwater elevations below 37.20 feet above the North American Vertical Datum of 1988. See equation 7 in table 1-1 for the submerged-weir flow coefficient. 


\section{Brogden Culverts (USGS station number 02312920)}

The Brogden culverts (fig. 1-1) are 0.2 mile east of the Brogden Bridge structure and work in parallel with the structure, separating the Inverness Pool from the Hernando Pool as water flows north. The site consists of two concrete culverts with a single gate covering the headwater side of both culverts. The gate was either closed or fully opened during the study period. No stage data were collected at the culverts, and the data collected by the SWFWMD for Brogden Bridge structure headwater and tail-water streamgages were used to develop a rating curve.

The Brogden culverts gate was only opened for small periods when the headwater rose above the invert elevation. Four discharge measurements were made by USGS personnel from August 2012 to October 2013, under free orifice flow, and the discharges ranged from 0.33 to $36.1 \mathrm{ft}^{3} / \mathrm{s}$. The free orifice rating was calibrated using equation 1 (table 1-1). One measurement was not used in rating development because the frame for the gate was positioned above the invert of the culvert, blocking flow (fig. 1-11). As a result, the measurement plotted low of the rating by -36 percent. The three measurements produced an average flow coefficient (C) of 0.30 and plot within $-8.4-6.9$ percent of the estimate. More discharge measurements are necessary to verify the rating and calculate any backwater effects on flow through the culvert.

\section{Van Ness Structure (USGS station number 02312970)}

The Van Ness structure (fig. 1-1) is one of two outlets from the Hernando Pool and discharges water to Two Mile Prairie (fig. 1-1), which is a landlocked wetland system. The structure consists of a single vertical lift gate and was only open for a short period of time in 2012 (during the discharge measurement portion of the study from 2010 to 2013) because water levels were below regulation guidance for most of the study period (SWFWMD, 2010). The gate was opened in 2013 for 2 days in an attempt to rate the structure. Submerged orifice flow was computed using criteria from equations 2 and 3 (table 1-1), and submerged weir flow was computed using criteria from equations 7 and 8 (table 1-1). The SWFWMD collected gate opening, headwater stage, and tail-water stage data, which were used for potential rating development.

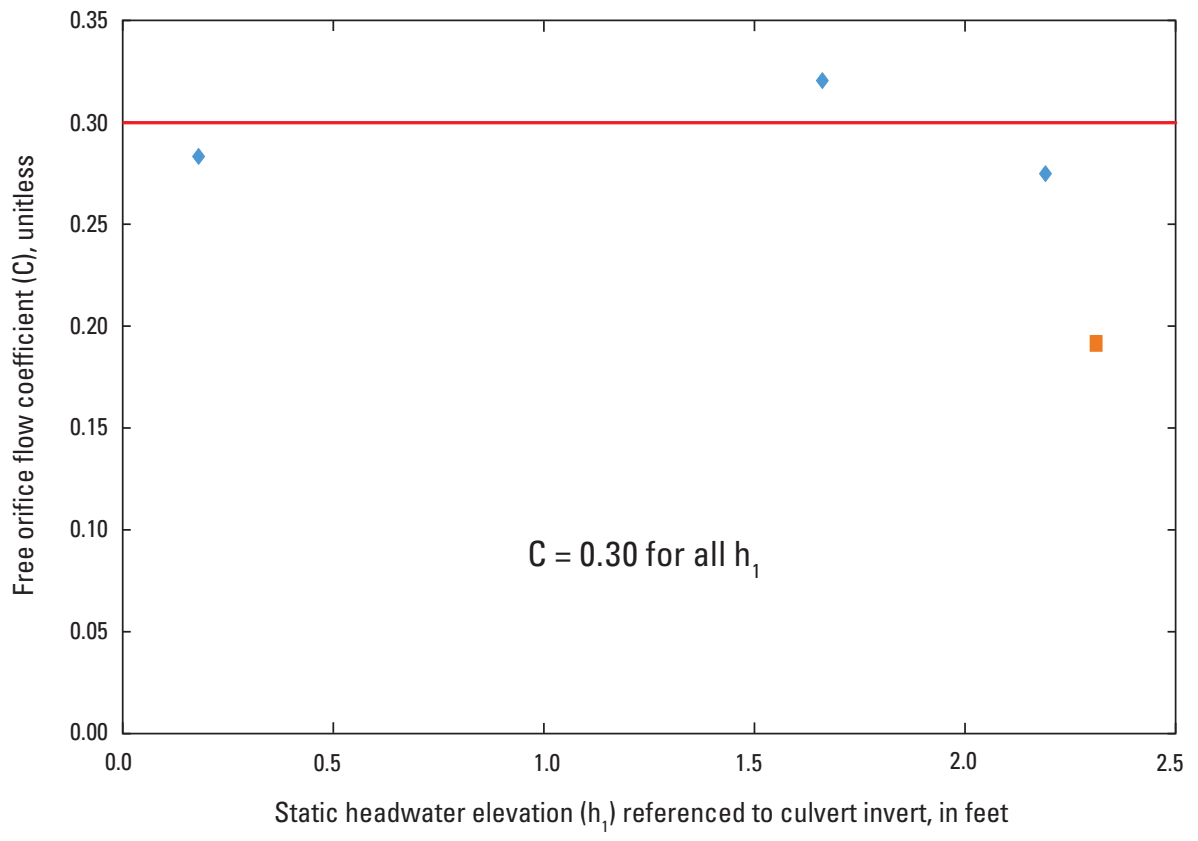

EXPLANATION

- Discharge measurement used in rating

- Discharge measurement not used in rating

Figure 1-11. Free-orifice discharge rating curve for the Brogden culverts structure. See equation 1 in table $1-1$ for the free-orifice flow coefficient. 
A limited number of discharge measurements were made at the Van Ness structure because water levels were below regulation in the Hernando Pool (fig. 1-1) for most of the study period. The structure was opened for a short time in 2013 in an attempt to rate the structure, but water never overtopped a ridge in the wetland just downstream. Three measurements were made by USGS personnel in 2013, which resulted in two measurements of submerged orifice flow (using criteria from equation 2 [table 1-1]) at the same settings and one measurement of submerged weir flow (using criteria from equation 7 (table 1-1). The submerged orifice measurements resulted in an average flow coefficient $\left(\mathrm{C}_{g s}\right)$ of 0.43 . For the weir flow measurement, because only submerged weir flow was measured, the free weir coefficient $\left(\mathrm{C}_{w}\right)$ was assumed to be constant and equal to 1.0, dropping the term from the submerged weir flow equation. The calculated value of $C_{w s}$ was 0.36 . It should be noted that these coefficients were calculated using only one gate setting for each type of flow with very few discharge measurements, and the resulting coefficients are considered very poor.

\section{S-353 Structure (USGS station number 02312975)}

The S-353 structure releases water from the Hernando Pool to the Withlacoochee River (fig. 1-1). The structure is used to create flood storage or minimize flooding in the Tsala Apopka Lake (SWFWMD, 2010). Neither of these criteria were met during the data collection period of study from 2010 to 2013, and the structure was closed the entire period. No discharge measurements were made by USGS personnel with the structure gates opened during the data collection study period. The SWFWMD collected gate opening, headwater stage, and tail-water stage data; however, a rating curve was not developed for this study.

\section{References Cited}

Collins, D.L., 1977, Computation of records of streamflow at control structures: U.S. Geological Survey Water-Resources Investigations Report 77-8, $57 \mathrm{p}$.

Franz, D.D., and Melching, C.S., 1997, Full equations utilities (FEQUTL) model for the approximation of hydraulic characteristics of open channels and control structures during unsteady flow: U.S. Geological Survey Water-Resources Investigations Report 97-4037, 205 p.

Levesque, V.A., and Oberg, K.A., 2012, Computing discharge using the index velocity method: U.S. Geological Survey Techniques and Methods, book 3, chap. A23, 148 p. [Also available at $h t t p: / / p u b s . u s g s . g o v / t m / 3 a 23 /$.

Southwest Florida Water Management District [SWFWMD], 2010, Operational guidelines for the Tsala-Apopka Chain of Lakes: No. 19-1, 4 p. [Also available at http://www. swfwmd.state.fl.us/files/database/site_file_sets/2269/TsalaApopka_Chain_of_Lakes [1].pdf.]

Southwest Florida Water Management District [SWFWMD], 2017, Index of Tsala Apopka structure flows from 2004 to 2013: accessed August 22, 2017, at http://ftp.swfwmd.state. fl.us/pub/GWIS/Tsala_Apopka_Structure_Flows_2004 to_2013/.

U.S. Geological Survey, 2017, National Water Information System-Web interface: accessed March 22, 2017, at https://doi.org/10.5066/F7P55KJN.

Villemonte, J.R., 1947, Submerged-weir discharge studies: Engineering News Record, p. 866-869. 
For more information about this publication, contact Director, Caribbean-Florida Water Science Center U.S. Geological Survey 4446 Pet Lane, Suite 108 Lutz, FL 33559

(813) 498-5000

For additional information visit https://www2.usgs.gov/water/caribbeanflorida/index.html

Publishing support provided by Rolla, Lafayette, and Pembroke Publishing Service Centers 


\section{晜}

흘

울

옹

言

옹

旁

言

을

商

궁

흘

产

$\infty$

魯 